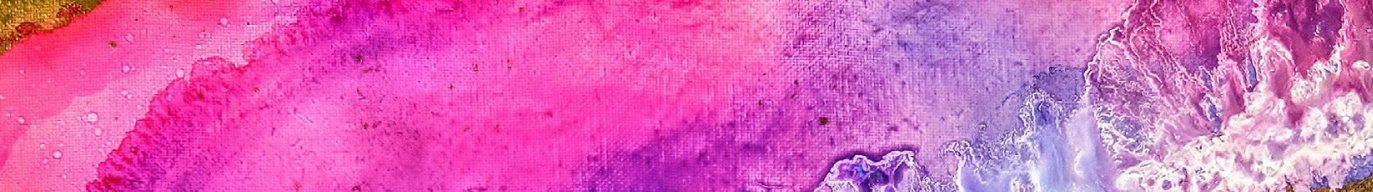

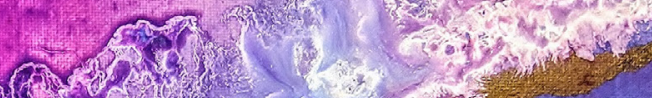

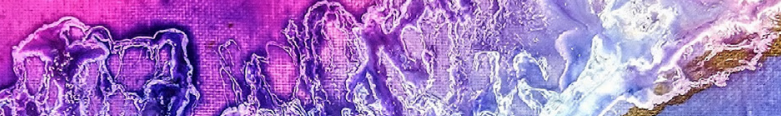

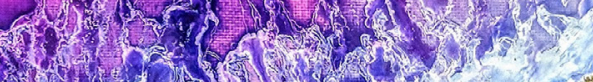

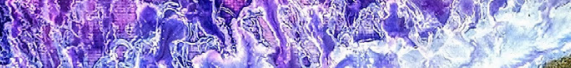

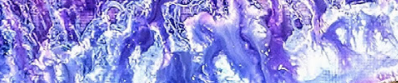

A.

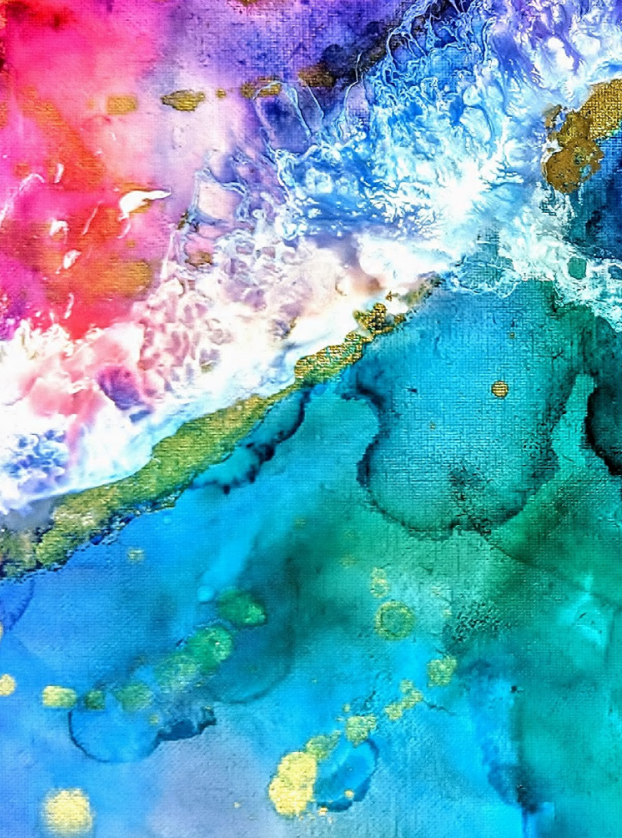

ANDRÉIA DELMASCHIO

\title{
ENSAIOS DE \\ LITERATURA \\ BRASILEIRA \\ CONTEMPORÂNEA
}

\section{:8:}

Edifes

Edifes 
ANDRÉIA DELMASCHIO

\section{ENSAIOS DE LITERATURA BRASILEIRA CONTEMPORÂNEA}

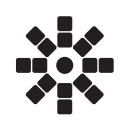

Edifes

Vitória - ES, 2017 
Editora do Instituto Federal de Educação,

Ciência e Tecnologia do Espírito Santo

R. Barão de Mauá, n 30 - Jucutuquara

29040-689 - Vitória - ES

www.edifes.ifes.edu.br | editora@ifes.edu.br

Reitor: Jadir Jose Pela

Pró-Reitor de Administração e Orçamento: Lezi José Ferreira

Pró-Reitor de Desenvolvimento Institucional: Luciano de Oliveira Toledo

Pró-Reitora de Ensino: Adriana Pionttkovsky Barcellos

Pró-Reitor de Extensão: Renato Tannure Rotta de Almeida

Pró-Reitor de Pesquisa e Pós-Graduação: André Romero da Silva

Coordenador da Edifes: Nelson Martinelli Filho

Conselho Editorial

Ediu Carlos Lopes Lemos • Eliana Mara Pellerano Kuster • Diego Ramiro Araoz

Alves (Suplente) Estéfano Aparecido Vieira $•$ Karin Satie Komati (Suplente) • Felipe

Zamborlini Saiter $\bullet$ Marcela Ferreira Paes (Suplente) $•$ Nelson Martinelli Filho •

Poliana Daré Zampirolli Pires • Oscar Luiz Teixeira de Rezende (Suplente) • Raoni

Schimitt Huapaya $\cdot$ Marcos Vinicius Forecchi Accioly (Suplente) $\bullet$ Ricardo Ramos

Costa $\cdot$ Ana Paula Klauck (Suplente) $\cdot$ Priscila de Souza Chisté $\bullet$ Robson Malacarne

(Suplente) $•$ Rossanna dos Santos Santana Rubim • Norma Pignaton Recla Lima

(Suplente) • Wallisson da Silva Freitas

Revisão e produção editorial: Roberta Patrocínio de Amorim

Projeto Gráfico, Diagramação e Capa: Assessoria de Comunicação Social do Ifes

Imagem de capa: shutterstock_47326840.jpg/shutterstock.com

Dados Internacionais de Catalogação na Publicação (CIP)

Bibliotecária Rossanna dos Santos Santana Rubim - CRB6- ES 403

D359 Delmaschio, Andréia, 1969-

Ensaios de literatura brasileira contemporânea / Andréia

Delmaschio. - Vitória, ES: Edifes, 2018.

$232 \mathrm{p}$.

ISBN: 9788582633120 (e-book.).

1. Literatura brasileira - Crítica. 2. Ensaios brasileiros. I. Título.

CDD $22-869.4$

DOI: $10.36524 / 9788582633120$

@ 2019 Instituto Federal do Espírito Santo

Todos os direitos reservados.

É permitida a reprodução parcial desta obra, desde que citada a fonte.

O conteúdo dos textos é de inteira responsabilidade do autor.zzz 
Aos meus antigos, atuais e futuros alunos, melhor incentivo durante o percurso. 



\section{SUMÁRIO}

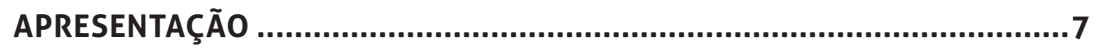

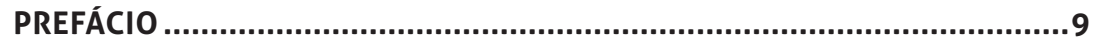

\section{CAPÍTULO 1}

CHICO BUAROQUE: ROMANCES PÓS-UTÓPICOS? .....................................13

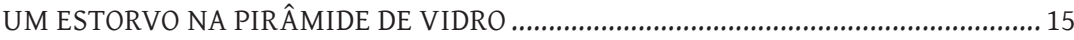

BENJAMIM: O MODELO E A MÁQUINA …………………………………………...... 59

CHICO BUARQUE E O CORAL DE VENTRÍLOQUOS ..................................................... 85

\section{CAPÍTULO 2}

RADUAN NASSAR: AS RELAÇÕES ENTRE PODER E PRAZER.....................119

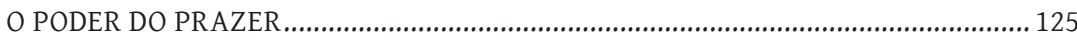

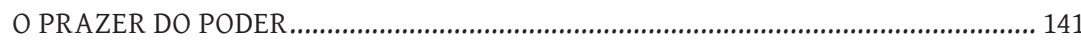

\section{CAPÍTULO 3}

GUIMARÃES ROSA: VEREDAS DE SAGARANA ....................................... 155

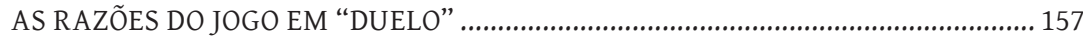

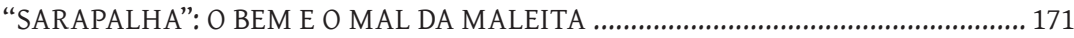

“SÃO MARCOS”: A MIMESE COMO PRODUÇÃO DA DIFERENÇA .................................. 181 


\section{CAPÍTULO 4}

RENATO PACHECO: DUAS FACES DA ORFANDADE EM FUGA DE CANAÃ ...193

HERMAN E O EXÍLIO NA TERRA NATAL.................................................................... 195

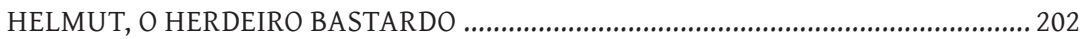

\section{CAPÍTULO 5}

EVANDO NASCIMENTO: CANTOS PROFANOS

“TENTAÇÃO DOS SANTOS”: PECADO, CONFISSÃO E PERDÃO

A CONDIÇÃO HUMANA EM “TERRA À VISTA” 


\section{APRESENTAÇÃO}

Os ensaios reunidos aqui foram selecionados da minha produção crítica acerca da literatura brasileira contemporânea. Cobrem as duas últimas décadas em que venho atuando como professora e pesquisadora de literatura e língua portuguesa, no Instituto Federal do Espírito Santo, período durante o qual tive a oportunidade de cursar o mestrado em Estudos Literários na Ufes e o doutorado em Ciência da Literatura na UFRJ.

Quase todos os textos que intento apresentar agora a um novo público leitor foram publicados anteriormente em periódicos especializados ou como capítulos de livros. Para esta nova publicação, foram revistos, sem terem sido contudo descaracterizados. Foram feitas as devidas adequações ao acordo ortográfico, quando foi o caso, e acrescentou-se uma ou outra nota, para esclarecimento ou atualização de dados. As datas das consultas originais a sites, por exemplo, foram mantidas, por me parecer que dizem mais do percurso real da pesquisa do que o faria uma atualização pro forma. Os textos guardam, assim, as marcas do percurso, cujo traçado importa tanto quanto o lugar a que se pretende chegar.

Na seleção, privilegiei os ensaios sobre prosa. Aqui estão estudos de contos, novelas e romances de autores brasileiros já lidos e consagrados mundialmente, como Guimarães Rosa, e de ficcionistas que fizeram sua obra e renome entre as décadas de 1970 e a atualidade, como Chico Buarque, Raduan Nassar, Renato Pacheco e Evando Nascimento. 
O fio condutor das reflexões, além da sensibilidade pessoal e do gosto que guiou as escolhas, passa por aspectos teórico-metodológicos que reafirmam, entre outras, a minha afinidade com o pensamento da desconstrução. São presenças constantes ao longo desse caminho pensadores como Antônio Cândido, Jacques Derrida, Michel Foucault, Roland Barthes, Sigmunt Freud, Walter Benjamin e Zygmunt Bauman.

O ensejo aqui é compartilhar, antes de tudo, um modo específico de ver, sentir e perscrutar as diferentes textualidades que foram postas sob o cuidado de um olhar ao mesmo tempo crítico e afetuoso para com um dos produtos mais elaborados do trabalho humano: a literatura.

Andréia Penha Delmaschio Ifes - Vitória, 2017 


\section{PREFÁCIO}

Os trabalhos reunidos neste livro são versões de ensaios já publicados por Andréia Delmaschio que se dispersam por periódicos e por capítulos de livro, entretanto, a vizinhança entre eles cria um efeito de ineditismo e fornece as marcas da (des)construção no percurso intelectual da autora. O livro de Andréia Delmaschio constitui um campo de experiências de leituras heterogêneas ao reunir os nomes: Guimarães Rosa, Chico Buarque, Raduan Nassar, Renato Pacheco e Evando Nascimento. A partir de autores da literatura brasileira contemporânea tão distintos entre si, a autora consegue fiar uma questão chave: a capacidade da ficção de formular perguntas sobre a ética. Nesse sentido, esta coletânea de artigos parece apostar na literatura como um campo de cultivo dessas perguntas que, obviamente, devem ser constantemente cultivadas, porque, enquanto houver vida, elas nunca serão formuladas de modo definitivo.

Apostar na literatura como campo de cultivo de questões sobre a ética contraria aquele velho senso comum que busca, nesse campo, exemplos de respostas aos dilemas morais, pois não há respostas ou certezas, mas um constante deslocamento das perguntas. Para sustentar tal aposta, Andréia coloca suas fichas nos procedimentos de fertilização mútua, os textos da literatura brasileira que analisa inseminam e são inseminados por textos da literatura mundial, o cinema, a arquitetura, os reality shows e as obras de Antônio Cândido, Jacques Derrida, Michel Foucault, 
Roland Barthes, Sigmund Freud, Walter Benjamin e Zygmunt Bauman. Este livro é resultado dessas fertilizações.

Jacques Derrida disse certa vez que a Literatura é uma instituição que transgride a sua própria institucionalidade. Para que a literatura potencialize os efeitos de transgressão da sua própria institucionalidade, é preciso que ela encontre leitores que estejam dispostos a pensá-la a partir dessas transgressões. Este é um princípio derridiano ao qual Andréia permanece fiel nas diversas intervenções que realiza. A presença de Jacques Derrida pode ser medida nesses trabalhos antes nos modos de pensar e problematizar a literatura a partir desses efeitos de transgressão, do que propriamente no número de vezes em que é citado. Esse é, talvez, um dos ensinos que a professora Andreia nos deixa, mostrar-nos que escrever com alguém não é necessariamente escrever sobre alguém.

Neste livro temos algumas contribuições importantes para a história da recepção crítica da ficção de Chico Buarque. A leitura que Andreia empreende em Um estorvo na pirâmide de vidro revela a estrutura pharmakônica do bode expiatório e expõe o mito da integração entre as classes sociais no Brasil, num vertiginoso diálogo com a sociologia de Bauman, George Orwell e Ivan Klíma. Em Benjamim: o modelo e a máquina, Andréia revela pela sua leitura áreas de indecidibilidade cruciais nessa ficção: corretora X prostituta, mobilidade $\mathrm{X}$ imobilidade, fotografia $\mathrm{X}$ fotografado, etc. Através dessa análise o leitor é levado a se questionar sobre o estatuto ético da relação entre o sujeito e seus dispositivos tecnológicos. Onde termina um e começa o outro? "Não é mais a máquina que surge como acessório para ele; trata-se antes do contrário.", conclui Andreia. Ao ler Budapeste, Andreia demonstra como a transgressão das fronteiras tacitamente aceitas entre ficção e realidade coloca problemas para os princípios institucionais que asseguram noções como o direito autoral e a paternidade.

No capítulo dedicado a Raduan Nassar, Andréia revisita um velho conhecido, o autor foi objeto de sua pesquisa de mestrado. Ao explorar as relações entre poder e prazer, Andréia estreita 
laços com o pensamento de Foucault para fornecer relevo ao papel fundamental do dispositivo da confissão e do discurso confessional na ficção de Nassar. O dispositivo da confissão é apontado como técnica por excelência para o controle da sexualidade na pastoral cristã, cujo alvo é preferencialmente o corpo feminino. Desse modo, Andréia nota que "Paradoxalmente, o personagem masculino, que dispensa toda lei e toda ordem, é, ele principalmente, que necessita 'confessar-se', delineando a ambivalência da confissão, seu caráter pharmakônico: 'se por um lado redime, a confissão por outro também pode liberar: mais do que nunca posso agir como fascista...".

Transitar pelas veredas do texto de Guimarães Rosa, depois de tantos grandes nomes da crítica já terem deixado aí as suas marcas, torna-se uma tarefa de grande responsabilidade. Em "São Marcos”: a mimese como produção da diferença, Andréia encara a tarefa logo pela vereda mais repisada, o conto mais trabalhado em toda Sagarana. A noção de "ilusão referencial" torna-se uma baliza para o exame da relação entre narrador e leitor no conto de Rosa. Durante o percurso, Andréia delineia uma pequena teoria da leitura da ficção, derivada dos arranjos textuais do conto de Rosa: "A narrativa rosiana, ao mesmo tempo em que declara a imprescindibilidade de um espectador ativo, impõe sua visão múltipla sobre uma base material única; entretanto, desdobrável ao infinito."

Sempre com um olho no texto literário e outro no mundo que a cerca, Andréia Delmaschio abordará a questão da imigração alemã no estado do Espírito Santo através do romance Fuga de Canaã: decadência de uma família alemã, no Brasil, de Renato Pacheco. As desterritorializações linguísticas que impedem o suicida de deixar um bilhete inteligível como última declaração tornam-se uma metáfora do processo de migração.

A sensível leitura que Andréia realiza da obra de Evando Nascimento também marcará a história da recepção crítica dos textos de ficção desse autor. Lendo a "Tentação dos Santos" a partir de uma intuição desconstrutiva, Andreia aponta para "a promiscuidade, para muitos insuspeitada, das relações entre sexo e religião, ficando ao 
encargo do leitor perscrutar as inúmeras implicações que podem advir dessa mescla, tanto quanto - por que não dizer - o seu resultado prático na vida cotidiana".

Ao fim da viagem, a vizinhança entre esses textos-intervenções forma um jardim, não o jardim bem podado e higienizado do estado moderno de que nos fala Andréia em Um estorvo na pirâmide de vidro, mas um jardim selvagem cujas fronteiras foram transgredidas de tal maneira que não se pode mais limitar os canteiros. Ao olhar esse jardim selvagem por cima, entendemos que já não é mais de ficção ou de teoria que se trata, mas da própria vida na forma de suas perguntas mais inquietantes.

Henrique de Oliveira Lee Professor do Programa de Pós-graduação em Estudos da Linguagem da UFMT Doutor em Literatura Comparada pela UFMG Cuiabá, 28 de Agosto de 2017. 


\section{CAPÍTULO 1}

CHICO BUARQUE:

ROMANCES PÓS-UTÓPICOS? 



\section{UM ESTORVO NA PIRÂMIDE DE VIDRO}

Lido por alguns pesquisadores como um romance pós-moderno, Estorvo entrelaça, num tempo em que ainda ecoam utopias modernas, duas imagens - a do jardim e a da casa de vidro -, como índices, respectivamente, do espírito de poda e da Glasarchitektur que marcaram a Modernidade. 0 romance é uma boa demonstração de como os conceitos, ideias e metáforas que constituíram o afã de "jardinagem" típico do Estado Moderno estão presentes hoje, como continuidade ou retorno. Já a proposta moderna da arquitetura em vidro, de forte expressão ainda na atualidade, tem na matéria-prima, devido a algumas de suas características, um índice de pobreza de experiência, no sentido benjaminiano da expressão, a partir da simulação sutil da ausência daquele material onipresente.

O sociólogo polonês Zygmunt Bauman, em Modernidade e ambivalência, desenvolve dois subcapítulos a "O escândalo da ambivalência" em que traça um curto porém fundamental histórico do "espírito de jardinagem" que caracterizou o Estado Moderno. Ele mostra como o discurso científico, em especial o da medicina, associou-se à "tradicional metáfora da jardinagem" com o intuito de suplantar a desordem e a espontaneidade de certos mecanismos sociais, por meio de um planejamento de controle estatal. Trata-se de um movimento discursivo (no início presente nas falas de médicos, psicólogos, psiquiatras, biólogos, zoólogos e sociólogos) que vai desaguar, por fim, em acontecimentos da dimensão do Shoah, tratado por seus 
mentores como uma estratégia de "engenharia social", a "solução final" para o "problema judeu" realizada pelos pioneiros especialistas, aqueles que, como muitos especialistas de hoje, em geral se responsabilizam apenas e tão somente pelos atos que desenvolvem dentro do território estrito da "sua" especialidade, como se fosse possível delimitar uma barreira inequívoca entre disciplinas e áreas, e ignoram, muitas vezes, a amplitude do conjunto de saberes em que, por extensão, atuam, e mesmo desobrigando-se de conhecer o resultado final de suas ações.

Para Adorno, toda a educação após Auschwitz tem como tarefa primeira a exigência de que Auschwitz não se repita. Em suas palavras, "não podemos evitar ponderações no sentido de que a invenção da bomba atômica, capaz de matar centenas de milhares literalmente de um só golpe, insere-se no mesmo nexo histórico que o genocídio". Hoje, temos que acrescentar outras ameaças, químicas e biológicas, sem contudo permitir que o aspecto de novidade dessas outras desgraças obscureça o perigo que a bomba atômica ainda talvez mais se deva dizer cada vez mais - representa.

Do mesmo modo que vários pensadores do Shoah, Bauman não o considera um ato de barbárie, justamente pelo fato de ter havido um planejamento de cada ação que culminou na morte de aproximadamente seis milhões de judeus. Considerá-lo uma explosão passional incontrolada de pessoas ou grupos insanos poderia significar uma abertura de caminho para o esquecimento e mesmo o risco de sua repetição histórica. "O genocídio é um instrumento racional para as suas finalidades, embora psicopata em termos de qualquer ética universalista" (BAUMAN, 1999, p. 46). Desse ponto de vista, as atrocidades cometidas por governantes como Hitler e Stalin "não foram nem explosões de barbarismo ainda não plenamente extinto pela nova ordem racional da civilização, nem o preço pago por utopias alheias ao espírito da modernidade. Ao contrário, foram produto legítimo do espírito moderno, daquela ânsia de auxiliar a apressar o progresso da humanidade rumo à perfeição que foi por toda parte a mais eminente marca da era moderna" (BAUMAN, 1999, p. 38). Ao 
longo de seu estudo vai tomando corpo a inevitável comparação do sistema de ideias modernas com os que compõem as sociedades capitalistas em que vivemos hoje; ressalta-se aí o modo como certos planos de "engenharia social" e "seleção natural" ecoaram e foram aclamados por décadas - alguns vigendo ainda na atualidade, como não é difícil constatar:

Assim [por exemplo], um dos mais eminentes e aclamados zoólogos de fama mundial e ganhador do Prêmio Nobel de 1973, o professor Konrad Lorenz, declarava em junho de 1940: 'Há uma certa similaridade entre as medidas que precisam ser tomadas quando traçamos uma ampla analogia biológica entre corpos e tumores malignos, por um lado, e uma nação e os indivíduos que nela se tornaram anti-sociais devido à sua constituição deficiente, por outro lado... Qualquer tentativa de reconstrução usando elementos que perderam sua natureza e características próprias está fadada ao fracasso. Felizmente, a eliminação de tais elementos é mais fácil para o médico de saúde pública e menos perigosa para o organismo supra-individual do que seria tal operação cirúrgica para o organismo individual' (BAUMAN, 1999, p. 37).

A necessidade de domesticação das forças naturais e o desejo de eliminação das arestas sociais indesejáveis, que comprometeriam a realização do projeto de construção do Estado Moderno, solicitavam a recorrência cada vez mais frequente às imagens da poda, do uso do ancinho, do corte de ervas daninhas e do sacrifício dos botões prematuros, nos discursos de pensadores das mais variadas especialidades. É o "estado jardineiro" atuando na construção da Modernidade. Sob os seus planos de ordenação higienista estavam, como grama desordenadamente crescida, "criminosos, estupradores, idiotas, débeis mentais, imbecis, lunáticos, bêbados, viciados em drogas, epiléticos, sifilíticos, pervertidos morais e sexuais e pessoas doentias e degeneradas" (BAUMAN, 1999, p. 44). No afã de chegar-se a um ponto zero de onde partisse a construção da Modernidade, estava criado o "delírio universalista da tábula rasa" (BAUMAN, 1999, p. 46), que pretendia justificar a visão do homem como uma 
espécie de vegetal do qual interessava cultivar as melhores mudas, fazendo-as proliferar, e eliminar aquelas que comprometessem a saúde - e a simetria - do canteiro.

Não é preciso esmerar-se na busca para encontrar, hoje, diferentes discursos movidos ainda por esse mote e baseados no mesmo fundamento, divulgando conteúdos discriminadores de etnias e preferências religiosas e sexuais, quando não ideais declaradamente nazistas. Só nos Estados Unidos existem hoje mais de setecentos grupos oficialmente dedicados ao ódio interétnico. ${ }^{1}$

Trazendo ainda para mais perto da "nossa" área o conjunto de exemplos, relembramos um artigo em que o professor José Augusto Carvalho, especialista em Linguística, defende a pena de morte para criminosos, em substituição à prisão. O texto, intitulado "Pena de morte para os inocentes", é de 1997. O articulista insinua, desde o título, o argumento central de que, se não houver pena de morte para os criminosos, a parcela "inocente" da sociedade é que sofrerá as consequências. O título, no entanto, ao tentar despertar no leitor a curiosidade sobre quais seriam os tais inocentes sujeitos à pena de morte, sem querer, demonstra já uma outra face do problema, trazendo à tona uma certa ambiguidade.

A dúvida, criada como base da dissertação, provoca no leitor o desejo de separar sem erro, para melhor entendimento do contexto que lhe é apresentado, duas categorias: criminosos e inocentes. Sabe-se no entanto que a distinção não é realizável de modo simples, em nenhuma das áreas de conhecimento que se baseiam no direito de julgar e punir e, principalmente, quantas impropriedades são cometidas dentro do atual sistema penal brasileiro - para permanecermos neste nosso contexto -, recorrente ele próprio às especialidades como delineadoras das distinções requeridas.

1 No Brasil a onda de neofascismos vem crescendo e ações francamente higienistas, que pareciam, até há pouco tempo, coisa do passado, avultam, por exemplo, em governos como o atual, de João Dória, em São Paulo, que trata a comunidade de usuários de drogas não como uma questão de saúde pública, mas antes de limpeza urbana. 
No caso específico do texto de Carvalho, a eliminação gradual da ambivalência presente no título, durante a argumentação, visa, obviamente, a conduzir os leitores a seguirem o raciocínio do ensaísta no caminho da proposta, que culmina na eliminação do "elemento perverso". Afirma Carvalho: "é inconsistente o argumento de que não houve diminuição da criminalidade nos países em que há a instituição da pena de morte. Afinal, nos países em que há cadeias também não houve diminuição da criminalidade, e nem por isso devemos ser contrários ao sistema penitenciário" (CARVALHO, 1997, p. 25).

De um certo ponto de vista o texto é claro, objetivo, técnico. Devido porém a certos malabarismos de pensamento dificilmente acompanháveis por leitores menos aptos, muitos podem ficar reféns da própria explicação convincente que é dada pelo autor após cada proposição inicial. Não é possível elaborar contra-argumentos concomitantemente à leitura e à tentativa de compreender as ideias e os argumentos que nos são apresentados ali, porque o texto exige do leitor que se esforce para entendê-lo. É necessário tempo para uma segunda leitura. A possível réplica é obrigada a assumir assim, desde o início, seu status secundário. É uma leitura que a priori não possibilita o diálogo.

Rico em argumentos e implacável em sua defesa da pena capital, o artigo provavelmente suscitará, em críticos desse tipo de punição, um estranhamento que pode mesmo provocar a desconfiança de que o autor não esteja falando sério. Mas como, perguntamos, já que se trata de assunto tão importante e as ideias são assumidas por uma pessoa influente, formadora de opinião e professor universitário da área de humanidades, tendo sido o texto lançado em veículo de circulação pública? Destacamos um trecho em que a sanha higienizadora se vale da conhecida metáfora da fruta estragada e contagiosa:

O objetivo da prisão ou da execução do criminoso é apenas eliminar a fruta podre que ameaça o cesto inteiro. A diferença é que a pena de morte é definitiva, à prova de fugas, de indultos e de reincidências. [...] Alegar que a sociedade se iguala ao assassino ao admitir que a pena de morte é também uma forma de assassinato 
é furtar-se à argumentação séria. Matar um facínora não é matar um ser humano, mas livrar a humanidade de um agente do mal; é evitar que outros inocentes morram em suas mãos; é eliminar da face da Terra alguém que seria mais útil à humanidade se nunca tivesse existido. Lutar contra a pena de morte é preferir a vida de um bandido à vida dos justos (CARVALHO, p. 25-26).

Apesar de o autor aparentemente habitar um mundo dividido, de modo sumário, entre "bandidos" e "justos", a riqueza argumentativa soa perversa e quase cínica, nesse contexto, demonstrando a utilização, por parte de um especialista, do seu conhecimento e aparato linguístico para defender, de modo irresponsável, um ponto de vista mais que controverso. Ainda que o autor posteriormente tenha vindo a público, em entrevista, afirmar tratar-se de um "mero exercício de argumentação", exemplar para os aprendizes de técnicas redacionais, não é um caso que deva ser ignorado, afinal aponta para algo grave e já conhecido: a utilização de conhecimentos específicos em defesa de um tipo de extermínio, sob o argumento de que se "exercita", apenas, um campo de certa especialidade.

Esse mesmo espírito de poda, fundador do Estado Moderno e vigente ainda hoje em muitas áreas de pensamento, está presente também na ficção de Chico Buarque. O narrador de Estorvo descreve o delírio de que é tomado o jardineiro que, em prol da casa de vidro, elimina as plantas que crescem à sua volta: de início pode-se ver ali apenas um inocente trabalhador, em sua função romântica, restrita ao âmbito do jardim. Contudo, se a receita moderna para higienização da sociedade fosse aplicada ao território de Estorvo, pouco restaria de seu frágil contingente de habitantes, a iniciar pelo narrador e incluindo o próprio jardineiro, facilmente qualificáveis em pelo menos uma daquelas categorias citadas anteriormente como perseguidas pela sanha ceifadora dos modernos reformadores.

É possível olhar o Estorvo de muitos ângulos, mas o que interessa aqui, especialmente, é acompanhar o percurso do narrador como elemento social que escapole e põe em xeque a plenitude da ordem e a segurança tão almejadas pelos habitantes pós-modernos da cidade de vidro. 
É esse o punctum (para lembrar o termo de Barthes) que nos atrai no romance, como um ponto de punção numa fotografia. Mais que um personagem pós-moderno, pode ser esclarecedor pensá-lo, nessa mesma linha interpretativa que vimos seguindo com Bauman, como aquele que, a partir do nome, se alinha aos "dejetos sociais" que ameaçam, com sua presença, a desejada pureza do Estado Moderno. Necessária e paradoxalmente presentes nas sociedades capitalistas atuais, eles comprometem agora a plena instituição da simples exclusão, ao mesmo tempo em que a justificam.

Considerá-lo portanto um personagem pós-moderno, como tentativa de esgotar a questão, pode ser uma forma indireta de aceitação da ideia de estigma ou mesmo de destino do elemento indesejado. Ele é antes o observador narrador do caos criado justamente pelo desejo de ordem e de anulação das diferenças ditas anômalas. Em torno dele acumulam-se os acidentes que constituem a narrativa: a inundação, o arrombamento, o estupro, o aborto, o roubo, o assassinato, a perseguição e a miséria. As situações aparentemente desconexas que vão surgindo fazem parte do funcionamento de uma mesma engrenagem e a narrativa aos poucos expõe essa mútua dependência.

Assim, embora provenha do extrato burguês, o personagem que narra não tem posses, não possui nem mesmo um nome, não trabalha, não mantém nem propaga a herança, é ausente da família de que se origina e abandona o outro núcleo, que consegue formar temporariamente. Vive só, é perseguido por "fantasmas", sustenta-se graças às doações da irmã e termina envolvido com traficantes e pessoas que usam o antigo sítio da família para plantar maconha. Em seu percurso, ele passa pelo convívio de diferentes grupos de dejetos humanos da sociedade organizada e legal, sem contudo identificar-se de fato com nenhum deles.

Ambas as barreiras (a portaria do condomínio e a porteira do sítio - esta volátil somente à entrada e aquela apenas à saída) são vigiadas por espécies de big brothers. Eles são personificados, no condomínio, pelos vigilantes das guaritas e, no sítio, pelos irmãos gêmeos que dão as ordens, gigantes violentos que criam e impõem ali dentro as suas 
próprias leis. Os irmãos, que o protagonista não consegue distinguir um do outro, agem sempre de modo contrário entre si, ao modo dos gêmeos de Alice no país das maravilhas e de tantos outros pares, monstruosos ou geniais, espalhados pela história da literatura.

No início o narrador é obrigado a seguir entre os dois homens, num veículo, e depois, quando entram no trailler onde acontecem as negociações, surge a antinomia: enquanto um deles aceita as joias que lhe são oferecidas, o outro as arremessa violentamente ao chão, golpeando o narrador na face e fazendo-o perder os sentidos. Logo depois, quando ele tenta fugir do local, um dos irmãos lhe barra a passagem, enquanto "o outro me oferece água, que ponho na boca e vira sangue” (BUARQUE, 1991, p. 70). O duplipensar (nomeado double think, no romance 1984) demonstrado pelos gêmeos é talvez o traço mais importante da sociedade Big Brother:

Quando vou catar as pedras, recebo na face direita um golpe violento, não sei se de algum objeto ou de joelho, ou ponta de bota ou caratê, e o susto é maior do que a primeira dor. o foco da dor adormece e ela se irradia para o resto da minha cabeça, e a envolve, e é fora da cabeça que a dor me dói. Rodeado de dor, eu mesmo não sinto mais nada, e estou cego e surdo. (...) Ainda cego, começo a ouvir uma desavença que não entendo, mas sei que se dá entre os dois gêmeos; discutem com vozes tão idênticas que parecem vozes de um só homem em contradição. Depois um deles se retira, e o outro me levanta pelo pescoço, conduzindo-me para fora (BUARQUE, 1991, p. 69-70).

A tática usada pelos gêmeos de Estorvo coincide com aquela já há muito conhecida da polícia e por ela utilizada na coação contra suspeitos, mas que também fora divulgada por parte da mídia brasileira, em meados da década de 2000, como sendo o modo mesmo como costumam agir as quadrilhas especializadas em sequestros, sejam eles tradicionais ou relâmpago, verdadeiros ou falsos sequestros (nestes últimos, a recompensa é conseguida mediante a ameaça de eliminação de uma pessoa que sequer foi raptada): ao telefone, alternam-se dois componentes da quadrilha; um demonstra ódio 
pela vítima e extremo descontrole, representando o risco iminente de se cumprirem as ameaças de morte; o outro, cujo discurso se intercala com o daquele, representa o "lado bom" e racional da quadrilha, e declara não haver interesse em exterminar o raptado ele faz o elo, garante a continuidade e a manutenção da vida. O teatro macabro, usual então no Brasil, tinha como objetivo dar aos familiares um tempo mínimo para que conseguissem o dinheiro relativo ao resgate, simulando um equilíbrio entre as partes boa e ruim que asseguraria a "reputação" da quadrilha, a confiança na sua palavra.

No condomínio de luxo em que mora a irmã do protagonista, o esquema Big Brother se faz presente através dos guardas e do sistema de vigilância como um todo (armas, câmeras e aparelhos de comunicação). E ainda que falte aos big brothers do sítio invadido o aparato tecnológico, portando eles somente armas, os dois homens de estatura incomum representam a figuração ficcional de um daqueles que Bauman chama "os 2 big brothers", referindo-se ao criado por George Orwell no romance 1984 e também ao que funciona na sociedade contemporânea. O sociólogo polonês afirma que a decretação da morte do primeiro foi um pouco apressada. Explorando a expressão Big Brother como metáfora de um conjunto de estratégias, modelos e técnicas, aparelhos de controle, condução, domesticação e domínio das mentes e dos corpos, Bauman afirma que o antigo seria aquele do tipo Bentham/Foucault, o Big Brother das vel has fábricas e prisões. O novo Big Brother seria, como no caso do Estorvo, o das armas mortíferas manipuladas pelos gêmeos no sítio e configurar-se-ia nos atuais circuitos fechados de TV para vigilância, como os utilizados nas portarias dos condomínios. Àquele primeiro interessava ainda incluir, docilizando os corpos e mantendo-os sob domínio. A este importa antes identificar as pessoas que não se ajustam, para então poder excluí-las do convívio social.

Nesse ponto - e por essa característica - é que apareceu a identificação do Big Brother de Orwell com os reality shows, como sínteses das nossas sociedades. De acordo com Bauman, "Ambos os Big Brothers - o antigo e o novo - sentam-se lado a lado nas cabines de controle 
de passaportes dos aeroportos, mas o novo examina com minúcia os documentos de viagem na chegada, enquanto o antigo os verifica, de modo mais superficial, na partida" (BAUMAN, 2005, p. 162-163).

Os comentários de Bauman são mesmo amplamente aplicáveis aos gêmeos que dominam o antigo sítio da família do narrador: "Entre eles, os dois irmãos policiam e servem à linha de fronteira entre o 'dentro' e o 'fora'. Suas respectivas esferas de ação funcionam bem em conjunto, dependendo da sensibilidade, da porosidade e da vulnerabilidade das fronteiras" (BAUMAN, 2005, p. 163). Também em Estorvo sobressai uma certa "deriva" das voláteis barreiras de propriedade vigiadas pelos gêmeos, num dentro e num fora, separados sem exatidão: "Encontrar aberta a cancela do sítio me perturba. Penso nos portões dos condomínios, e por um instante aquela cancela escancarada é mais impenetrável. Sinto que, ao cruzar a cancela, não estarei entrando em algum lugar, mas saindo de todos os outros. Dali avisto todo o vale e seus limites, mas ainda assim é como se o vale cercasse o mundo e eu agora entrasse num lado de fora" (BUARQUE, 1991, p. 24). E mais adiante: "A cancela do sítio não está aberta nem fechada. Solta do barco após cinco anos, chicoteia para dentro e para fora, tal qual vela de barco na procela" (BUARQUE, 1991, p. 67).

O Big Brother mais antigo, aquele criado pela pena de George Orwell, governava fábricas fordistas, acampamentos militares e outras incontáveis prisões, grandes e pequenas, do tipo Bentham/ Foucault - seu único desejo era manter nossos ancestrais lá dentro e trazer as ovelhas desgarradas de volta ao rebanho. O Big Brother do reality show está preocupado unicamente em manter os homens (e mulheres) estranhos - os desajustados ou menos ajustados, os menos inteligentes ou menos determinados, os menos dotados e os menos habilidosos - de fora. E uma vez fora, eternamente fora (BAUMAN, 2005, p. 162).

Enquanto o antigo Big Brother tinha como estratégia a inclusão, uniformizando, designando lugares e funções e preocupando-se em manter os corpos indóceis sob domínio, o novo Big Brother identifica 
os desajustados, banindo-os, por suas fraquezas, para o "seu devido lugar", ou seja, mantendo-os à distância.

O novo Big Brother fornece aos agentes da imigração listas de pessoas cuja entrada não deve ser permitida, e, aos banqueiros, as listas daquelas que não devem figurar na companhia de quem merece crédito. Ele instrui os guardas sobre quem deve ser detido na entrada, sem direito a ingressar na comunidade cercada. Inspira os vigilantes do bairro a observarem e expulsarem os gatunos e vagabundos suspeitos - estranhos fora de lugar. Oferece aos proprietários circuitos fechados de TV para manterem os indesejados longe das portas de suas casas. É o padroeiro de todos os leões-de-chácara, quer a serviço de uma boate ou de um ministro de Estado do Interior (BAUMAN, 2005, p. 162).

Para pensadores como Bauman, o antigo Big Brother ainda está vivo, e mais ativo que nunca, sendo agora encontrado nas áreas periféricas e marginalizadas do espaço social, como guetos urbanos, campos de refugiados ou prisões. A tarefa de alinhar pessoas e mantê-las constantemente sob vigilância é amplamente aplicada nesses locais. Contudo se trata de um papel secundário em relação ao desempenhado pelo novo estilo Big Brother. Na verdade, a função daquele é facilitar o trabalho deste.

Juntos, eles abrangem todo o universo social. Só é possível sair do reino soberano de um Big Brother para entrar na propriedade do outro - e uma das funções do Big Brother ao estilo antigo é fazer com que você encare a irritante e repulsiva atenção de seu irmão mais novo como uma graça salvadora, uma operação salva-vidas e a garantia de uma existência segura e jubilosa. A crueldade desumana do primeiro sustenta a duplicidade diabólica do segundo. Isto é, na medida em que a única escolha oferecida pelo mundo em que avançamos diariamente a partir das nossas realizações e no qual se tecem as nossas existências é entre ficar na linha e ser rejeitado - entre as jurisdições do primeiro ou do segundo dos Big Brothers que presidem conjuntamente o jogo da inclusão obrigatória e da exclusão compulsória (BAUMAN, 2005, p. 163). 
Já os vigilantes do condomínio em que vive a irmã do narrador estão imersos num esquema no mínimo ambíguo, porque, embora subempregados, são eles no entanto que exercem o poder de decidir quem pode ultrapassar as fronteiras daquele território. São peças engajadas na proteção de um espaço que não lhes pertence, mas que, ao contrário do sítio abandonado, se mostra potencialmente assaltável. Ao contrário do que ocorre na erma propriedade rural, ali, na mansão de vidro, ainda há o que furtar. E, afinal, mesmo os esquemas de vigilância do novo Big Brother se mostram falíveis.

Estando no sítio abandonado, o estorvo narrador dorme no chão, junto com crianças famintas. Na lista dos aleijões sociais que desfilam pelo romance não faltam, além de ladrões e traficantes, um corcunda, uma empregada doméstica, uma paralítica, um flanelinha e um homem com olho de vidro. Num verdadeiro teatro da prótese, ao ser embarcado numa viatura policial, o narrador entrega ao motorista, para que este possa guiá-lo, a perna postiça que segue ao seu lado, no banco de trás. Por fim, o narrador aparece como invasor da própria propriedade, a redundância da expressão expondo já o paradoxo: "O ex-pugilista indica-me com a metralhadora, e diz que também nunca deu nada por mim, julgava-me um ladrão de bolsas, um malandrinho, um pé-rapado. E agora descobriu que sou o dono daquele sítio. Apressa-se a explicar que não estou ali para desalojar ninguém, pelo contrário, trago uma proposta interessante para todos nós" (BUARQUE, 1991, p. 137).

Do mesmo modo como se aproxima dos grupos marginalizados, como que naturalmente e sem razão que o justifique, ele também se afasta. Seu comportamento, como diria Bauman referindo-se a nossa época, aponta para a “[...] suspeita de intenções iníquas e inclinações criminosas, essa geração tem poucos motivos para tratar a 'sociedade' como um lar digno de lealdade e respeito" (BAUMAN, 2005, p. 22).

A descrição faz retomar, ainda uma vez, à Modernidade histórica e lembra a reflexão de Benjamin sobre 
O contexto em que viveu Baudelaire, a Paris do Segundo Império, “capital do século XIX', [que] evidencia o surgimento de uma experiência urbana nova para o homem ocidental: a vida na grande cidade, a metrópole-labirinto, onde o sujeito poderia se perder, naufragado na multidão, e onde todos os crimes poderiam ser cometidos, já que seria 'impossível manter boa conduta numa população densamente massificada onde cada um é desconhecido de todos os demais e não precisa enrubescer diante de ninguém" (OLIVEIRA, 2005, n.p.).

Pelas mesmas razões não parece difícil para o narrador do Estorvo furtar, sem escrúpulos, as joias da irmã que o sustenta: "Dentro da última chapeleirinha encontrei uma bolsa de camurça clara. Intrometi-lhe a mão e toquei as jóias da minha irmã. Em mostruário ou em corpo de mulher, minha vista pode não discernir a jóia nobre. Mas havia como que uma transpiração naquelas pedras, e minha mão logo captou a sua natureza. A mão já entorpecia ali dentro, e não sabia mais largar as pedras" (BUARQUE, 1991, p. 60). Afinal, para além da memória das experiências partilhadas pelos dois na infância, não há qualquer tipo de identificação sua com o universo habitado por ela, no qual ninguém sequer disfarça o quanto ele é indesejado:

\footnotetext{
O vigia me vê subindo a ladeira, repara nas minhas solas, e acredita que eu seja o primeiro pedestre autorizado a transpor aquele portão. A casa 16, no final do condomínio, tem outro interfone, outro portão eletrônico e dois seguranças armados. Os cães ladram em coro e param de ladrar de estalo. Um rapaz de flanela na mão abre a portinhola lateral e me faz entrar no jardim com um gesto da flanela (BUARQUE, 1991, p. 14).
}

Ao chegar à casa da irmã, sem o saber em meio a uma festa, ele lista as impressões que tem das funções ou profissões que os convidados desempenham em suas vidas, tentando dar-lhes uma identidade. Ele próprio no entanto fica fora do longo rol que formula, escapando à classificação, especialmente porque, mesmo antes da festa, ele já mantém com o contexto familiar da irmã uma relação desconfortável, alimentada pela dificuldade de expressão dos afetos, tanto quanto pela quebra da rede de propriedade. Como a ideia de posse 
não o penetra verdadeiramente, o surgimento automático de uma necessidade, que o conduz a aceitar da irmã um dinheiro, também faz com que o perca com a mesma facilidade com que o ganha, e leva-o, assim também, a furtar-lhe as joias e a ter, em seguida, de entregá-las à dupla de traficantes que domina o sítio da família.

Se eu soubesse que minha irmã dava uma festa, teria ao menos feito a barba. Teria escolhido uma roupa adequada, se bem que ali haja gente de tudo que é jeito; jeito de banqueiro, jeito de playboy, de embaixador, de cantor, de adolescente, de arquiteto, de paisagista, de psicanalista, de bailarina, de atriz, de militar, de estrangeiro, de filantropa, de ministro, de jogador, de construtor, de economista, de figurinista, de contrabandista, de publicitário, de viciado, de fazendeiro, de literato, de astróloga, de fotógrafo, de cineasta, de político, e meu nome não constava da lista (BUARQUE, 1991, p. 55).

Tendo apenas chegado à festa, ele lamenta não estar vestido conforme a ocasião; depois percebe que não importa ou não basta usar a roupa adequada, ou que a roupa adequada talvez nem exista, mesmo porque ali estão, no seu modo de ver, pessoas com diferentes “jeitos”, e não propriamente identidades, embora ele mesmo não resista à tentação de enquadrá-las em tipos. o que faz a ele diferente não é meramente a aparência, e sim a falta de algo como o domínio de um código, como a senha que abre aos convivas o caminho para aquele mundo, e que, ele o intui, pode bem ser algo tão volátil quanto o próprio "jeito" assumido por cada um. O que lhe falta é uma identidade, ainda que temporária e inventada, como aquela que ele imagina para cada um dos convidados - "e meu nome não constava da lista". Ele é inqualificável, e é justamente isso que constitui nele o estorvo. Ele passa, praticamente sem ser notado, por entre os convidados, indo se misturar por fim com os garçons, na invisibilidade típica dos que apenas servem.

o cunhado representa, na narrativa, um claro contraponto a sua situação: é casado e financeiramente bem-sucedido, reside em condomínio de luxo e dá ordens aos serviçais. Para apresentar o personagem narrador a um dos convivas, ou seja, para dar-lhe enfim 
existência, o cunhado escolhe a identidade que lhe parece mais convincente, provavelmente pela vasta aplicabilidade: a de artista - ou "meio artista":

Meu cunhado me alcança com o amigo grisalho, a quem me apresenta dizendo 'é esse'. O grisalho diz que é sempre assim, que em toda família que se preze existe um porra-louca. Meu cunhado quer me defender e diz que sou meio artista, dá-me um soco nas vértebras e diz 'não é mesmo?' (BUARQUE, 1991, p. 57, grifos meus).

Para muitos, um artista nada precisa provar ou dar a ver com o seu trabalho. Para alguns, não é preciso nem mesmo que seu trabalho exista. O título, dos mais flutuantes, é, por isso mesmo, aplicado e autoaplicado quando urge uma identificação, em geral por exigência social, como é o caso em Estorvo.

Na posição em que se encontra, o narrador funciona como uma espécie de pharmakós ou bode expiatório. Na contracorrente das expectativas familiares e sociais, ele é contudo resultado da óbvia necessidade do grupo de aderir a alguém a diferença abominável (o porra-louca, a ovelha negra, a fruta podre, o estraga-prazeres, o meio artista), passível de ser excluída a qualquer momento, em nome do necessário restabelecimento da ordem temporariamente rompida. Dentro dessa lógica, desde que o elemento pervertido passe, por alguma razão, a integrar o establishment, somente a sua eliminação levará consigo os males daquela coletividade, que a partir de então estará de novo limpa, de corpo e alma.

A ovelha negra força o establishment a lhe torcer o nariz porque ameaça com o odor da miséria e, a não ser que a relação entre outsiders e insiders garanta grande segurança e fixidez aos estabelecidos, os de fora representam a outra ponta do barco, na qual existe o risco de ir-se parar, em caso de turbulência. "Eles" fazem lembrar, com sua presença, a que ponto de fragilidade pode chegar cada um de "nós". O escudo roto daqueles guerreiros grotescos parece, aos estabelecidos, um espelho borrado onde veem seu próprio fantasma maltrapilho. Em seu estandarte está escrito que gente pode sobrar, 
gente pode ser declarada inútil, gente pode tornar-se, repentinamente, refugo e lixo.

Com propriedade Norbert Elias afirma que "Em ordens sociais de extrema mobilidade, é comum que as pessoas sejam extremamente sensíveis em relação a tudo o que possa ameaçar sua posição. É comum que elas desenvolvam angústias ligadas ao status" (ELIAS, 2000, p. 167). "Odiamos essas pessoas porque sentimos que aquilo que elas sofrem diante de nossos olhos bem pode se mostrar, e muito em breve, um ensaio de nosso próprio destino" (ELIAS, 2000, p. 158).

De um modo geral circula (por vezes tacitamente) o argumento de que sempre foi dada ao desviado a chance de recuperação, o aviso de que por ora ainda é possível integrar-se, desde que se obedeça às normas que regem o bem-estar familiar e, de modo mais amplo, a ordem social. Assim sendo, o estorvo é aquele que não quis ou não conseguiu integrar-se à norma. Cínicos ou hipócritas, o pensamento e as ações de exclusão se esquecem daquilo que Zygmunt Bauman ressalta muito bem na seguinte formulação:

A lei é um projeto, a planta de um hábitat claramente circunscrito, compreensivelmente marcado, mapeado e sinalizado. É a lei que dá existência à anarquia, ao traçar a linha que divide o dentro do fora. A anarquia não é meramente a ausência da lei; ela nasce da retirada, da suspensão, da recusa da lei. O convite da lei à universalidade soaria cínico não fosse a inclusão que ela faz do excluído por meio de sua própria retirada. A lei jamais alcançaria a universalidade sem o direito de traçar o limite de sua aplicação, criando, como prova disso, uma categoria universal de marginalizados/ excluídos, e o direito de estabelecer um 'fora dos limites', fornecendo assim o lugar de despejo dos que foram excluídos, reciclados em refugo humano. Do ponto de vista da lei, a exclusão é um ato de auto-suspensão. Isso significa que a lei limita sua preocupação com o marginalizado/excluído para mantê-los fora do domínio governado pela norma que ela mesma circunscreveu. A lei atua sobre essa preocupação proclamando que o excluído não é assunto seu. Não há lei para ele. A condição de excluído consiste na ausência de uma lei que se aplique a ela (BAUMAN, 2005, p. 43). 
O Estorvo é um fora da lei. Pelas mesmas razões postas por Bauman, o destaque, nessa expressão, não deve ser dado ao fora, como se a ação do sujeito designasse simplesmente uma opção, mas sim à lei, por ser ela o elemento excludente, plenamente atuante e interessado na conquista indiscriminada - e por isso discriminadora - dos espaços. O elemento estorvante representa o recuo das ambições típicas da Modernidade, como clareza e ordem, cuja perseguição discreta ainda sobressai, sua busca coincidindo agora com o momento de decadência. Não por acaso, é o estorvo narrador o observador e, de um modo atípico e apático, o narrador do trabalho de jardinagem obsessiva do empregado da casa de vidro. Enquanto das utopias da cidade moderna faziam parte a liberdade e a racionalidade, agora, num tempo dito por muitos pós-utópico, é flagrante contudo a existência de novas utopias, orquestradas como ecos daquelas.

Algumas das análises que afirmam o fim das utopias encaram-nas, implicitamente, como um sonho ou desejo coletivo, ou que teria como objeto uma coletividade. No entanto, no seu sentido primeiro, o termo utopia designa o lugar almejado e sempre inalcançado, sonhado, pelo indivíduo, para si ou para a sociedade em que vive. 0 que se percebe atualmente não é portanto o fim das utopias, e sim o enfraquecimento das utopias sociais, ligado à ausência de preocupação com o outro, recolhida a alteridade como relação consciente e, do mesmo modo, a consciência da própria inserção na coletividade.

No lugar das categorias citadas anteriormente como utopias modernas, prevalecem hoje, nas cidades - especialmente naquelas que vivem o caos da violência, da miséria e/ou da guerra, com exemplos situados por todo o globo -, as utopias do conforto e da segurança individuais ligadas ao consumo de bens e ao afã de perpetuação dos privilégios, assumindo, cada uma delas, determinados formatos de discurso e diferentes veículos para propagação desses mesmos discursos, o que, é preciso notar, não as afasta completamente das utopias modernas, antes aguça os seus temas, lamentavelmente, no sentido da individualidade. 
Inundando essa suposta ilha de segurança, desde sempre ilusória, apresenta-se o narrador de Estorvo, arrastando atrás de si o caos. Concluímos, com Bauman, que “O caos, 'o outro da ordem', é pura negatividade. É a negação de tudo o que a ordem se empenha em ser. É contra essa negatividade que a positividade da ordem se constitui. Mas a negatividade do caos é um produto da autoconstituição da ordem, seu efeito colateral, seu resíduo e, no entanto, condição sine qua non da sua possibilidade (reflexa). Sem a negatividade do caos, não há positividade da ordem; sem o caos, não há ordem" (BAUMAN, 1999, p. 15).

Assim portanto, em vez de mero representante do individualismo pós-moderno apontado por alguns críticos, o estorvo narrador é antes um fio de Ariadne que se desenrola pelo labirinto da "pós-modernidade", expondo-o aos nossos olhos. A própria confusão mental em que se encontra pode ser o indício, ainda que em gérmen, de alguma resistência: "Vejo a multidão fechando todos os meus caminhos, mas a realidade é que sou eu o incômodo no caminho da multidão" (BUARQUE, 1991, p. 106). Em meio ao desejo geral de segurança, clareza e ordem, é ele quem traz à tona a incerteza, a ambivalência e o caos. Ainda de acordo com Bauman, "A ambivalência é um subproduto do trabalho de classificação e convida a um maior esforço classificatório" (BAUMAN, 1999, p. 11). Assim como a eliminação de resíduos cria, no mundo, ainda mais resíduos, os atos que tentam resolver problemas de ambivalência são os mesmos que criam novos problemas.

Em Amor e lixo, romance do escritor tcheco Ivan Klíma, o protagonista nota que tudo à sua volta se transforma em dejetos, desde os produtos até às pessoas, descartáveis, e as relações afetivas, natimortas. Contudo, ele mantém a sua integridade e, em meio à série de conflitos por que passa, segue numa linha de questionamentos sobre si, sobre o homem em geral e mesmo acerca de deus e da alma, ao modo de um personagem dostoievskiano.

Já em Estorvo, o narrador, envolto no torvelinho dos acontecimentos, percebe os seus próprios contornos se diluindo irremediavel- 
mente, junto com os dos demais a sua volta, e nada faz para retê-los. Melancolia ou sentimento de perda não são vividos verdadeiramente; o que se nota são antes fiapos de lembranças que esvanecem. A visão turva que o narrador tem do outro por detrás da porta - "não consigo definir aquele sujeito através do olho mágico" (BUARQUE, 1991, p. 11) é o mesmo defeito do olhar que faz com que os seres em geral percam a nitidez que permitiu qualificá-los como humanos, ao longo da história da civilização, graças à manutenção de certos valores.

o personagem de Klíma, um escritor fracassado, emprega-se na limpeza pública e passa a varrer as ruas de Praga, tendo o cotidiano pautado pela observação dos dramas pessoais dos companheiros de trabalho, pela tentativa de autoconhecimento e pelo reconhecimento terrível da indestrutibilidade do lixo:

Ocorreu-me que o que acabara de acontecer não passava de uma demonstração instrutiva de um fenômeno do dia-a-dia. A matéria não desaparece nunca. Pode, no máximo, mudar de forma. o lixo é imortal, ele impregna o ar, incha na água, se dissolve, apodrece, se desintegra, se transforma em gás, em fumaça, em fuligem, viaja através do mundo e gradualmente o engolfa (KLÍMA, 1993, p. 11).

Ele opta pelo trabalho como gari por acreditar que é ao mesmo tempo um modo de realizar algo útil e uma possibilidade de convívio com pessoas que, sentado à sua escrivaninha, jamais conheceria. Sua consciência porém se eleva acima do monte de lixo que recolhe diariamente, para tristemente contemplar.

Em Estorvo, o narrador, embora provenha de uma família de posses, é ele próprio um lixo humano, que se metamorfoseia paulatinamente, sempre no sentido da perda. Embora sua voz estabeleça um modo incomum de observação, rapidamente o próprio foco escolhido passa a fazer parte do meio: o estranhamento inicial do mundo absurdo em que vive aos poucos se naturaliza, minando toda possibilidade de resistência. Ele é empurrado para a rua pelos seus fantasmas, sendo tomado e levado como lixo num redemoinho. A narrativa segue um fluxo contínuo, cuja velocidade coincide com 
a do seu deslocamento pela cidade. 0 ponto de vista do narrador retira as coisas, pessoas e eventos do seu contexto, trazendo-os momentaneamente a uma espécie de flutuação em que se destacam, como poeira que brilha sob um foco de luz, para logo em seguida desaparecer no torvelinho opaco das sombras irreconhecíveis.

Quando segue para o antigo sítio abandonado da família, além de comer e beber junto com os indigentes que se escondem ali, dormindo ao lado de crianças maltrapilhas em colchonetes espalhados pelo chão, ele não leva para lá o que seriam pensamentos do extrato social de que provém. Antes se integra, como mais um átomo, à vida local. A cena, que poderia insinuar um romântico irmanamento entre as classes, indica a princípio indiferença e embotamento da consciência por parte do elemento decaído. Não há consciência, não há solidariedade, não há opção. Nem se poderia esperar isso do estorvo narrador. Afinal, se ele já não tem lugar no extrato social de que provém, ao mesmo tempo não pode simplesmente passar por um enjeitado originário. Ou seja, lá, no Jardim Botânico, ele levava o estigma do refugo humano; aqui, no sítio abandonado, ele traz o estigma da classe proprietária.

O personagem de Klíma, por outro lado, varre as ruas enquanto pensa sobre o homem e o lixo, e sobre o homem transformado em lixo. Ambos os personagens porém relatam a história de um tempo perverso, em que papéis usados e vidas humanas têm o mesmo valor. Estorvo - assim como a expressão Amor e lixo - é um título inusitado para um romance e também aponta o caminhar daquela escrita por diferentes figurações do dejeto, do torto, do sujo, do feio, do que tenta cavar sub-repticiamente o seu espaço na sociedade capitalista. A aproximação feita pelo título do romance tcheco entre amor e lixo sugere sutilmente a transmutação de um elemento no outro. Como tantos outros binômios rejeitados pela nossa tradição, romântica, esse paralelo insinua sem dúvida uma das terríveis conclusões a que chega o narrador: amor é lixo, uma evidência a que, a seu modo, procura ele, o tempo todo, reagir. 
Já o Estorvo traz, disposta ao modo de epígrafe, uma enumeração de termos que se assemelham gráfica ou semanticamente à palavra que lhe dá título, sequência iniciada pelo termo estorvo e por ele encerrada: "estorvo, estorvar, exturbare, distúrbio, perturbação, torvação, turva, torvelinho, turbulência, turbilhão, trovão, trouble, trápola, atropelo, tropel, torpor, estupor, estropiar, estrupício, estrovenga, estorvo" (BUARQUE, 1991, p. 7).

Esse pródromo faz pensar sobre quem ou sobre quê o livro falaria: o narrador ou o mundo em que desfila? o problema de estudos que enfocam primordialmente a caracterização do narrador de Estorvo como pós-moderno é justo minorizar a importância de certos elementos contextuais. Aliás, o comportamento que é definido pela crítica como esquizo ou pós-utópico, do estorvo narrador, não seria antes a marca de sua diluição no contexto? Ou será o contrário? Até que ponto é possível falar separadamente, em casos como este, de personagem e contexto, de figura e paisagem, se aquela se dilui nesta, sendo invadida, penetrada pelo ambiente que a cerca? Na última cena, enfim, o narrador é literalmente penetrado: alguém que é percebido por ele, já há algum tempo, como uma sombra, um vulto nebuloso, desperta-lhe um sentimento confuso. 0 gesto do personagem-narrador no entanto é mal interpretado e o outro perfura-o com uma arma branca, enquanto ele corre ao abraço daquela "camisa":

Reconheço o sujeito magro de camisa quadriculada no ponto do ônibus que desce a serra. Avistá-lo ali, não sei por que, enche-me de um sentimento semelhante a uma gratidão. Sigo correndo ao seu encontro, de braços abertos, mas ele me interpreta mal; encolhe os ombros e puxa uma faca de dentro da calça. É um facão de cozinha meio enferrujado, o gume carcomido, que ele mantém apontado à altura do meu estômago, e não terei como sustar meu impulso. Estou a um palmo daquele rosto comprido, sua boca escancarada, e já não tenho certeza de conhecê-lo. Na verdade, conheço-o apenas pela camisa quadriculada, e é a camisa que abraço com força, e agarro e esgarço. Recebo a lâmina inteira na minha carne, e quase peço ao sujeito para deixá-la onde está; adivinho que à saída ela 
me magoará bem mais que quando entrou. Ele empurra meu peito para desentranhá-la, e some na ribanceira que dá noutras bandas (BUARQUE, 1991, p. 140).

Embora não vivencie sentimentos de culpa pelas diferenças sociais que observa, é ele, enquanto narrador, o catalisador de contrastes e incongruências. Assim, a loja em que trabalha sua ex-mulher, por exemplo, expõe, na decoração, um desejo inconsciente de remissão da má-consciência historicamente adquirida pela vivência ostentatória da fartura: "A Alfândega é uma butique cara num shopping movimentado no quarteirão mais nobre da zona sul. Vende roupas importadas, acho, mas nunca entrei. Entro agora pela primeira vez, e não causo boa impressão. (...) Essas roupas estão jogadas pela butique com relativo desleixo, não para fingir que são baratas, mas para avisar que nem estão muito à venda" (BUARQUE, 1991, p. 36). Desse modo também, enquanto produzem mais e mais sobras (produtos feitos exatamente para sobrar), as sociedades capitalistas disfarçam em lixo, o luxo. Pobreza de experiência e apagamento das marcas.

O narrador de Estorvo é alguém - como tantos, inumeráveis e crescentes - que não encontra um lugar aonde tenha livre acesso. Todas as portas, porteiras e portarias lhe foram fechadas (a da casa da irmã, a do antigo sítio, a da loja onde trabalha a ex-mulher). o sentimento que desperta não é mais o de comiseração, porque ele já é um fruto maduro - ou apodrecido - da sociedade excludente. Em contrapartida, uma reação da mais completa indiferença guia os seus atos "contra" a indiferença dos demais, ao seu redor. Do mesmo modo como uma peça encontra outra numa engrenagem. É possível entendê-lo em seu irmanamento com aqueles que Bauman relembra - o lixo humano "selecionado com esmero" (BAUMAN, 2005, p. 73). "Os refugiados, os deslocados, as pessoas em busca de asilo, os migrantes, os sans papiers [que] constituem o refugo da globalização" (BAUMAN, 2005, p. 76. Conteúdo dos colchetes inserido por mim).

Os trabalhadores que servem aos moradores da casa de vidro guardas, garçons, copeiro, babá - têm, curiosamente, os seus modos já tão aderidos aos dos patrões, que chegam a discriminar o suposto 
invasor como se a casa fosse sua. É como se fossem, eles próprios, ameaçados por sua presença, o que não deixa de ser verdade. De modo indireto, ele ameaça a subsistência deles, já que é da existência daquela mansão que os empregados retiram o seu sustento. De modo direto porque, em caso de invasão à casa, a integridade física dos empregados também estará ameaçada. Assim, a presença do irmão da patroa, tão pobre quanto garçons e babás, representa para eles, paradoxalmente, uma ameaça. Muito mais que a presença dos patrões exploradores, o igual lhes intimida como se fosse um diferente, em mais essa curiosa estratégia de automanutenção do poder opressor do capital, que faz com que, por aderência, uma categoria inteira se aliene da sua realidade, da sua classe, da sua condição. 0 narrador percebe a repugnância que gera nos empregados, mas nem mesmo chega a estranhar, naturalizado que fora desde cedo ao embate surdo dos contrastes. Na posição em que se encontra, de invasor, os próprios objetos (a casa e o portão) repelem a sua presença:

O vigia na guarita fortificada é novo no serviço, e tem a obrigação de me barrar no condomínio. Pergunta meu nome e destino, observando os meus sapatos. Interfona para a casa 16 e diz que há um cidadão dizendo que é irmão da dona da casa. A casa 16 responde alguma coisa [Note-se desde já a personificação da casa: é ela quem responde, e não um de seus habitantes] que o vigia não gosta e faz 'hum'. O portão de grades de ferro verde e argolóes dourados abre-se aos pequenos trancos, como que relutando em me dar passagem (BUARQUE, 1991, p. 14. Conteúdo dos colchetes inserido por mim).

Do mesmo modo, cada tentativa de leitura enquadrante do Estorvo numa categoria (como, por exemplo, a de "retrato do Brasil contemporâneo" - slogan de promoção do lançamento do romance em Portugal, pela editora Dom Quixote) ${ }^{2}$ amplia o seu espectro ambivalente, tanto porque põe lentes de aumento sobre a sua fatura,

2 Luís Felipe Guimarães Soares tenta entender a razão das leituras de Estorvo como retrato do Brasil e percebe que são vozes orquestradas com a parte da crítica que propaga, ainda hoje, se não a ideologia nacionalista, o discurso do nacional. E resiste a isso, surpreendendo-se com a aceitação da expressão citada em vários países. 0 pesquisador destaca no texto 
quanto porque faz estenderem-se os tentáculos da sua produtividade escritural até os textos que o comentam. A tentativa simples de explicação do livro cria, sem perceber, uma demanda de outras novas tentativas, que vão abrindo ao infinito as possibilidades de leitura-escrita com o Estorvo. Um dos riscos de tal movimento interpretativo, que toma o romance simplesmente como "retrato do Brasil contemporâneo", é cair no terreno estéril da entronização dessa mesma ficção, destruindo o que ela tem de desafiadora de uma lógica interna à narrativa, ao lado dessa outra, social e exterior a ela.

Um texto como Estorvo, ao seu modo, pertence a uma linhagem cujo assunto nos interessa muito mais que como mero "tema literário", e que perpassa - além de uma série de outros romances, contemporâneos e precursores seus - a obra de diversos pensadores e cientistas sociais: as lutas pela manutenção do status quo, batalha em que grupos ditos estabelecidos (Elias) ou integrados (Bauman) excluem, do convívio social, outros grupos ou indivíduos.

Contrariamente à unidade do establishment, outsiders não é a caracterização de um grupo. A heterogenia do narrador por entre os serviçais da casa já o demonstra. Enquanto conceito, outsiders não aponta para uma unidade. Tendo como base uma pesquisa de campo, no estudo citado anteriormente, Norbert Elias explica, com relação ao termo, que se trata de um agrupamento heterogêneo de pessoas que não se unem por laços sociais efetivos, diferentemente do establishment, e que, sem se identificarem umas com as outras, desenvolvem mesmo diversas razões para antes alimentarem entre si desconfianças e antipatias. De acordo com Federico Neiburg, na apresentação à edição brasileira do livro de Elias, "A identidade social destes últimos [os estabelecidos] é a de um grupo. Eles possuem um substantivo abstrato que os define como um coletivo: são o establishment. Os outsiders, ao contrário, existem sempre no plural, não constituindo propriamente um grupo social" (ELIAS,

de Chico Buarque exatamente o contrário, o "desafio aos pressupostos desses enquadramentos" (SOARES, 1996, p. 123). 
2000, p. 7), o que acarreta em mais desagregação e agrava a sensação de não pertencimento.

Os nomes fictícios escolhidos por Norbert Elias - Winston Parva e Winston Magna - diferenciam as duas cidadelas onde se situa o seu trabalho e parecem ter sido retirados do romance 1984, de George Orwell, que se ambienta na Londres do pós-guerra. É no romance de Orwell que aparece pela primeira vez a expressão Big Brother: "Em cada patamar, diante da porta do elevador, o cartaz da cara enorme o fitava da parede. Era uma dessas figuras cujos olhos seguem a gente por toda parte. O GRANDE IRMÃO ZELA POR TI, dizia a legenda" (ORWELL, 1996, p. 7). No romance, Winston é o nome do personagem que, desde o início, vemos submeter-se, a despeito de seu pensamento questionador, aos desígnios do Big Brother - "O bigodudo olhava de cada canto. Havia um cartaz na casa defronte. O GRANDE IRMÃO ZELA POR TI, dizia o letreiro, e os olhos escuros procuravam os de Winston" (ORWELL, 1996, p. 8).

De um modo parecido a como o Winston de Orwell se submete aos ditames da sociedade Big Brother, guiado pela promessa do "zelo" e hipnotizado pelo olhar do Grande Irmão, a "Winston Parva" de Elias também se submete - a um tempo em que, ali, um grupo submete o outro -, entranhada num cruel e sistemático jogo de exclusão social em que "O drama todo foi encenado pelos dois lados como se eles fossem marionetes" (ELIAS, 2000, p. 50).

Em 1984, Winston é aquele que, contra toda proibição e vigilância, escreve um diário, deixando portanto um registro de seu tempo, 1984, uma data de que também não está muito certo e que, segundo consta, foi usada como título por Orwell em substituição a 1948 (primeira versão), a pedido do editor. Winston Smith (seu primeiro nome seria uma referência a Winston Churchill, e o segundo, o sobrenome mais comum na Inglaterra) é um dos representantes do Grande Irmão nos Dois Minutos de Ódio contra Emmanuel Goldstein, o inimigo número um do regime Big Brother.

Curiosamente, o fato de Norbert Elias "inventar" um nome para a cidade real em que realizara a pesquisa transforma-a em 
um personagem, desse modo, o ensaio sociológico carrega consigo um traço ficcional, o que, mais uma vez, aproxima-o do romance de Orwell. Note-se que os outsiders recém-chegados à Winston Parva de Elias são, em sua grande maioria, refugiados de Londres, gente que havia perdido suas casas em bombardeios e que agora buscava abrigo naquela localidade:

Elas foram sendo ocupadas não tanto em função do atrativo dos aluguéis, mas da mudança da situação do país. Depois da crise de Munique, um número maior de famílias de recrutas do posto de treinamento militar da região começou a ser levado para lá e, em 1940, o padrão de desenvolvimento sofreu uma mudança ainda mais drástica. Quando começaram para valer os bombardeios da Inglaterra, chegaram os desabrigados. Uma fábrica de Londres, que produzia equipamentos para as forças armadas e cuja sede fora destruída, transferiu-se para Winston Parva com armas e bagagens. A produção foi instalada num prédio fabril fora de uso, nas imediações do canal. Mais de 100 londrinos foram acrescentados à pequena comunidade de Winston Parva (ELIAS, 2000, p. 62-63).

Já no romance de George Orwell: "Winston foi até a janela, sempre de costas para a tela. O dia continuava claro e despejado. Nalgum lugar distante uma bomba-foguete explodiu com um estrondo surdo, ecoante. Atualmente, caíam em Londres, vinte ou trinta bombas por semana" (ORWELL, 1996, p. 28). E mais adiante:

A Pista 1 não tinha esse nome naquela época: chamava-se Inglaterra, ou Grã-Bretanha, embora Londres - disso tinha certeza quase absoluta - sempre tivesse sido Londres. Winston não podia lembrar definitivamente de uma época em que o país não estivesse em guerra, mas era evidente um intervalo de paz bastante longo durante a sua infância, porque uma das suas mais longínquas recordações era de um bombardeio aéreo que parecera a todos surpreender. Fora talvez quando a bomba atômica caíra em Colchester. Não se lembrava do bombardeio em si, mas lembrava-se do pai a segurar-lhe a mão com força, enquanto corriam para um lugar nas profundezas da terra, dando voltas numa escada espiral que fazia ruído sob seus pés e que 
por fim lhe cansou tanto as pernas que ele começou a choramingar e pararam para descansar (ORWELL, 1996, p. 34).

Pela migração de nome de um a outro contexto, graças à “invenção" de Elias, é como se o personagem de 1984 fosse o fundador simbólico daquela outra sociedade Big Brother que é a Winston Parva de Os estabelecidos e os outsiders. No ensaio sociológico, Elias explica que a cidadela tinha o nome do seu fundador, que ele troca por Winston para preservar a sua real identidade. Contudo, no capítulo 2 , em que relata - numa narrativa, diga-se de passagem, de certo sabor ficcional - a formação do povoado e explica o batismo dado às ruas a partir das letras do nome do fundador (Charles Wilson), o sociólogo acaba por revelá-lo:

\begin{abstract}
Alguns dos antigos residentes ainda se lembravam de como Charles Wilson costumava passear pelas ruas do município que havia criado, em sua carruagem puxada a cavalos, erguendo a cartola para cumprimentar os novos 'aldeões'. Lembravam-se da engenhosidade que ele havia demonstrado ao instalar sua olaria de modo a ter acesso direto aos desvios ferroviários por um túnel. Numa entrevista, um homem mencionou as ruidosas recepções oferecidas no lendário casarão do empresário, na rua principal, para celebrar as vitórias nos jogos de futebol de que seus filhos participavam. Provavelmente, essas reminiscências teriam agradado ao fundador de Winston Parva, mas, para garantir que seu nome se perpetuasse após a sua morte, ele escolhera os nomes das ruas ao sul da avenida principal do povoado de modo a formar com a primeira letra de cada um deles seu próprio nome: Ch... Chestnut Street; A... Acorn Street; S... Sycamore Street; W... Willow Street; I... Ilex Street; L... Lime Street; S... Sloe Street; O... Orchard Street; N... New Street (ELIAS, 2000, p. 61).
\end{abstract}

Estudando modos de domínio mais diretos e estratégias de estigmatização por vezes um tanto sutis, como a fofoca, Elias destaca várias alternativas de recepção e socialização possíveis, que poderiam ter resultado num outro tipo de relação com os recém-chegados à vizinhança. Nenhuma delas, porém, fora adotada pelos "lados" contendores, especialmente pelos estabelecidos. Os novos 
grupos que chegavam à localidade eram estigmatizados, humilhados e alijados do convívio com o establishment.

Ou seja: vítima, em certa medida, ele também, de uma sociedade do tipo Big Brother (cujo "olho" aberto era a própria comunidade espiã e fofoqueira), o establishment funciona como algoz do novo agrupamento de pessoas, vistas como outsiders por provirem, muitas delas, de desgraças coletivas, em especial os bombardeios da Segunda Guerra Mundial, que haviam destruído suas casas em outras cidades da Inglaterra, principalmente em Londres - assim como acontece com a casa do personagem de Orwell, no romance que inaugura o uso do termo Big Brother.

É Norbert Elias quem diz, a respeito dos relatos da fundação da "aldeia": "Essa história era transmitida de geração em geração e contada aos recém-chegados. Foi o filho de um londrino retirado de uma área de risco quem salientou o significado dos nomes das ruas, nas primeiras semanas da pesquisa" (ELIAS, 2000, p. 62). Temos assim um nome que migra da ficção para o ensaio etnológico, enviando a este, de algum modo, para o campo daquela. o livro de Elias adentra o campo ficcional, assim como o romance de Orwell se assemelha, em muitos aspectos, a um tratado sociológico (conferir especialmente o capítulo 17). Já se disse inclusive que 1984 é a prova maior de que é possível fazer arte politicamente engajada.

Em Estorvo também se apresenta uma certa unidade daqueles que pertencem ao grupo dos estabelecidos, para usar ainda o termo de Norbert Elias. O núcleo (bem) estabelecido inclui a irmã do protagonista, o marido, a filha, os amigos e os moradores do condomínio luxuoso.

Ao contrário do que se nota nos versos da conhecida canção do grupo de rock brasileiro Titãs, chamada "Miséria", que afirma: "Miséria é miséria em qualquer canto/ Riquezas são diferentes" (TITÃS, 1989), e onde portanto singularidade e pluralidade ("é"/"são") fazem coro com a ideia de nenhuma posse ou de sobeja, respectivamente, em Estorvo se percebe aquela unidade dos estabelecidos que os singulariza num grupo e que se baseia e fortalece na prática da exclusão do outro: o diferente, a ovelha negra, o porra-louca, o outsider. 
A diferença entre a letra da música e o romance, no que toca a singular e plural, se liga à prática destacada por Elias: a exclusão sistemática de um grupo por parte de outro pode se dar não somente ou principalmente com base na situação econômica de um deles. Assim, a canção dos Titãs se refere principalmente à desigualdade econômica, traço proeminente na geração de injustiça social e de exclusão, sobretudo no Brasil. Daí o fato de, adiante, o verbo ser ("Riquezas são / Miséria é") acompanhar, pluralizando ou singularizando, a situação material, denotando excesso ou escassez. Sendo usado sem o predicativo que naturalmente o acompanharia, ele acaba por destacar a própria "significação", o sentido único de sobra e falta que se quer enfatizar justamente pela enorme importância que a questão material tem ali. No contexto mundial, como também aqui, a esse aspecto se agregam outros, geradores, em conjunto, de um "equilíbrio" perverso. É Bauman ainda quem destaca: "como assinalam Paul e Ann Ehrlich, a Holanda pode suportar sua densidade populacional recorde porque outros países não podem" (BAUMAN, 2005, p. 57-58).

No caso do Estorvo, a condição econômica é apenas um dos fatores (também ele importante, se não central) que influenciam os movimentos excludentes. A prevalência da diferença de posses para a determinação da ação segregadora parece algo ainda hoje óbvio a um brasileiro, mas é provável que esse fator não alcance tal grau de elementaridade em outros países. O protagonista marginal e sua irmã estabelecida provêm de uma mesma família e classe social. Não fica claro se a atual condição econômica da irmã abastada fora galgada por meio da associação com o marido rico ou se é o contrário que se dá, mas é notório que algo além do econômico promove a cisão entre o protagonista outsider (destaque-se nessa expressão paradoxal a contradição que a ficção, como poucos ambientes, é capaz de criar) e o establishment. Sobre o establishment, afirma Norbert Elias: "A satisfação que cada um extrai da participação no carisma do grupo compensa o sacrifício da satisfação pessoal decorrente da submissão às normas grupais" (ELIAS, 2000, p. 26). 
A consciência clara dessa diferença é que faz com que o cunhado se refira ao protagonista como a ovelha negra da família. o tipo de relação que se desenvolve entre eles melhor explica as razões da discriminação. A fragilidade da posição desse irmão marginalizado se deve ao fato de que os membros do grupo estabelecido pelo qual ele circula mantêm entre si vínculos que na aparência (afinal, é, antes de tudo, de aparência que se trata) os une no seu medo de uma possível invasão de outsiders. Estes são diligentemente mantidos à distância, mesmo quando a estigmatização é disfarçada em auxílio financeiro, contradistribuição de parte do dinheiro em jogo, instrumento básico da separação: "Sem que eu tenha percebido minha irmã fazer qualquer sinal, o copeiro traz uma bandeja com o talão de cheques e a caneta de prata. Ela preenche o cheque, e seus cabelos castanhos não me permitem ver se está mesmo sorrindo, nem se esse sorriso quer dizer que eu sou um pobre diabo. A assinatura negligente, junto com o sorriso que não posso ver, quer dizer que aquele dinheiro não lhe fará falta. O ruído ríspido do cheque destacado de um só golpe pode querer dizer que esta é a última vez" (BUARQUE, 1991, p. 18-19).

“Experiência e pobreza", texto em que Walter Benjamin avalia a pobreza de experiências relatáveis perceptível nos sobreviventes dos campos de batalha da Primeira Grande Guerra (e a baixa cotação da experiência em geral no pós-guerra), faz referência a uma outra faceta daquela mesma vocação para anular toda e qualquer diferença que viesse a comprometer o plano social ordenador a que nos referimos anteriormente, o que o pensador chama de "nova barbárie" ou "barbárie positiva": "Pois o que traz ao bárbaro a pobreza de experiência? Ela o leva a começar do começo; a começar de novo; a saber se virar com pouco; a saber construir com pouco, sem olhar para a direita nem para a esquerda. Entre os grandes criadores sempre houve aqueles implacáveis, cuja primeira medida era fazer tabula rasa. Na verdade eles queriam pranchetas, pois eram construtores" (BENJAMIN, 1986, p. 196). 
Benjamin afirma que "Uma miséria totalmente nova se abateu sobre o homem com esse desenvolvimento da técnica (...)", referindo-se especialmente às tecnologias de guerra. E acrescenta: “(...) que é hoje em dia prova de honradez confessar pobreza. Sim, admitamos: essa pobreza de experiências não é uma pobreza particular, mas uma pobreza de toda a humanidade. Trata-se de uma espécie de nova barbárie" (BENJAMIN, 1986, p. 195-196).

Nesse texto, Benjamin destaca especialmente um traço das personagens de Paul Scheerbart", que é morarem elas "em casas de vidro, ajustáveis e deslocáveis, como as construídas, no meio tempo, por Loos e Le Corbusier" (BENJAMIN, 1986, p. 197). O vidro, material duro e liso, é também frio e sóbrio. Sobre ele nada se fixa. O vidro é inimigo da aura, do mistério e da propriedade. Numa casa de vidro e aço se apagam as marcas do habitante, o que denota o desejo de uma certa "nova pobreza". Nesse caso é óbvio que a pura positividade de uma experiência da impropriedade é meramente ilusória, considerando-se o custo de um material como o vidro, módico apenas na aparência: a falsa pobreza vem da percepção visual de quase inexistência do material, contrastante entretanto com os grandes custos de sua aquisição, devidos em parte à alta tecnologia necessária para fabricação e em parte ao status social que seus produtos adquiriram na Modernidade, e que ainda hoje mantêm. A "cultura de vidro" (BENJAMIN, 1986, p. 197) de que fala Scheerbart seria, para Benjamin, mais um sinal de

Pobreza de experiência: isso não quer dizer que os homens aspirem a uma nova experiência. Não, eles almejam libertar-se de toda experiência, aspiram a um mundo em que eles possam fazer valer tão pura e claramente a sua pobreza, externa e interna, sem que disso resulte algo decente. Nem sempre eles são ignorantes ou inexperientes. Muitas vezes podemos afirmar o contrário: 'Devoram'

\footnotetext{
3 Paul Scheerbart (1863-1915), escritor alemão de ficção científica que em 1914, no início portanto da Primeira Guerra Mundial, publicou o livro Glasarchitektur, em que defende uma nova arquitetura, alegando que o vidro, vindo substituir a alvenaria, transformaria a Terra num paraíso que dispensaria a espera pelo paraíso celestial.
} 
tudo isso, a 'cultura' e o 'homem', e estão supersaturados e exaustos (BENJAMIN, 1986, p. 197-198).

A pobreza de experiência de uma cultura de vidro seria, paradoxalmente, a pobreza de experiência dos experientes. De um modo geral, a civilização teria deglutido todo o patrimônio cultural, mal digerido, pelo excesso, e o seu organismo estaria saturado dele. Daí concluir-se que o caso não seja de ignorância ou ausência de experiência no sentido estrito, mas sim de encharcamento, pelo excesso. Os ecos dessa opção se fazem ouvir ainda atualmente, em especial nesse estágio da pós-modernidade característico do fim do século e conhecido na arquitetura como neomodernismo. De acordo com Carlos Antônio Leite Brandão,

Depois do pós-moderno e do deconstruction, a arquitetura surfa uma nova onda nesta virada de século: espaços limpos e sofisticados, vidros, elementos metálicos em profusão, paredes brancas, transparência e ênfase nos detalhes técnicos, no design dos objetos e mobiliário e no ambiente clean. (...) a adoção da ortogonalidade, da modulação, das técnicas industriais, dos grandes panos de vidro e espaços com o mínimo de apoio e da racionalização funcional e formal de todo o espaço deixam de ser instrumentos para a consecução de um ambiente promotor de uma vida melhor e mais feliz para a humanidade e tornam-se, apenas, cânones formais e padrões de beleza de uma modernidade consagrada apenas do ponto de vista estético (BRANDÃO, Carlos Antônio Leite. A arquitetura entre o renascimento do moderno e o luto da modernidade. Disponível em: <http://www.arquitetura.ufmg.br/ia/moderno.html>. Acesso em: 20 abr. 2006).

Com o vidro transparente e geométrico das construções modernas, o que sobressai, além das utopias de ordem, harmonia e racionalidade, é o desejo de apagamento das marcas. Sobre a superfície fria e dura, nenhuma sobra, nenhuma sombra, rastro ou adorno, nenhuma marca de pessoalidade. E mais: o ocultamento da própria matéria: a nova pobreza, sendo também a pobreza de experiências, representa o estágio de desenvolvimento tecnológico e de 
acúmulo material que permite utilizar uma matéria-prima que é, ao mesmo tempo, dura e frágil, que isola o ambiente enquanto o expõe e que necessita, em geral, do contraste com outros materiais para fazer-se visível.

o vidro paradoxalmente solicita, para sua visibilidade - ao contrário do que propõe facilitar para os conteúdos que ele envolve -, que um outro sentido (o tato) supere a hegemonia da visão: em certas ocasiões somente um cego pode "ver" o vidro. Mas se trata, aí também, de uma espécie de tato cego, porque tateia, ou pensa tatear, aquilo que está para além da superfície transparente do vidro. Assim, o habitante da cidade de vidro, que quer ser visto e que quer dar a ver os seus pertences (muitos deles também transparentes), ao mesmo tempo não quer ver a matéria que o separa do exterior, quer imaginar que ela não exista. É a nova pobreza, uma pseudopobreza que se liga à má-consciência das diferenças (sociais, econômicas) reconhecidas, porém não assumidas - muito menos em vias de serem solucionadas. Daí que todo o mobiliário e a ornamentação tendam também a caminhar no sentido da pseudoeconomia, da lisura, do leve, prático, liso, transparente e, se possível, invisível.

Desse modo, o narrador do Estorvo, que primeiramente segue aquela espécie de reflexo seu, depois, sem razão aparente, vai em busca da irmã, encontrando-a, por fim, na casa de vidro em que mora: "eu subo as encostas, as prateleiras da floresta, as ladeiras invisíveis, com mansões invisíveis de onde se avista a cidade inteira" (BUARQUE, 1991, p. 14). A casa dela, uma pirâmide de "arquitetura premiada", é feita dos mesmos materiais em que habitam os personagens de Scheerbart, e que sinalizam, no texto de Benjamin, para a pobreza de experiência: o vidro e o aço.

A casa da minha irmã é uma pirâmide de vidro, sem o vértice. Uma estrutura de aço sustenta as quatro faces, que se compõem de peças de blindex em forma de trapézio, ora peças fixas, ora portas, ora janelas basculantes. As poucas paredes interiores de alvenaria foram projetadas de modo que quem entrasse no jardim poderia ver o oceano e as ilhas ao fundo, através da casa (BUARQUE, 1991, p. 14-15). 
“Através da casa" é possível ver a paisagem distante. A vista para o mar é o índice maior de bom gosto, muito procurado nos imóveis e dos que mais os valorizam. Além da simples vista para o mar dos apartamentos de concreto, a casa de vidro deixa ver o mar através de si: o enorme contingente de água, para não dizer todo o meio natural, portanto pertence a ela e a ela serve, decorando-a. Melhor dizendo: o mar é ela, a natureza é dela; a estrutura de vidro traz até si tudo aquilo que está para além (para isso ela é posta, de modo estratégico, num lugar muito bem escolhido e previamente determinado). A casa de vidro agrega a si a paisagem, que funciona agora como uma tela: a visão do mar passa a compor a parede da casa, que desse modo se situa sempre mais além, como num desejo que se perpetua - nesse caso também literalmente - ao infinito. A invisibilidade da estrutura de vidro torna visível tudo o mais. No entanto, o que está além do vidro não pode ser tocado, experimentado. É à distância que ele tem sua existência possível. Para isso a matéria vítrea o separa, a um tempo em que o aproxima, dos habitantes da casa. Mas, como era de se esperar, a vista para o mar também não sacia mais. Observando depois outras habitações, o narrador afirma:

As pessoas que moram de frente para o mar nunca aparecem nas janelas. As vidraças vivem fechadas por causa da maresia, que oxida os metais, e para conservar o ar-condicionado. Essas pessoas ainda colocam cortinas com forro por trás das vidraças, e as fachadas ao longo da praia ficam vestidas de cortinas pelo avesso. Nos prédios mais modernos, os arquitetos criaram terraços imitando decks, que são decorados com móveis de vime ou fiberglass, e vasos com arecas ou samambaias. Mas as pessoas dos prédios modernos também têm pudor de aparecer nos terraços (BUARQUE, 1991, p. 94).

Assim como o terraço dos prédios modernos, a casa de vidro dá sinais de sua não habitabilidade: ali também é preciso pendurar cortinas para tentar isolar o sol e o calor. A arquitetura premiada não parece ter tido o conforto dos habitantes como motivo principal, por cumprir antes um projeto (nos sentidos lato e estrito do termo) planejado por outrem, os especialistas, projeto que almejava, 
provavelmente, nada mais que a referida premiação. No projeto, contraditoriamente, não entram os desejos dos que pagaram pela casa e terão de viver nela:

Obedecendo a sinais convulsos da flanela, contorno os automóveis na garagem transparente, subo por uma escada em caracol, e dou numa espécie de sala de estar com pé-direito descomunal, piso de granito, parede inclinada de vidro, outras paredes brancas e nuas, muito eco, uma sala onde nunca vi ninguém sentado (BUARQUE, 1991, p. 16).

A presença da casa de vidro num contexto pós-moderno, de certo modo soa patética, por tentar unir as utopias modernas, como essa, da transparência, com o aparato técnico de segurança característico dos dias atuais. De acordo com a arquiteta Marilice Costi, no artigo Casas que matam:

Atualmente, a casa é uma prisão. Seus usuários a fecham a sete chaves. São alarmes, câmeras, guardas, guaritas, grades, cercas elétricas. Este 'esconderijo' para si mesmo e de si mesmo não é saudável. Cada vez mais o indivíduo, de medo, se fecha [...] A arquitetura vem convivendo com os problemas sócio-econômicos mas ainda não encontrou uma solução para impedir que o homem seja prisioneiro de sua própria casa. Uma casa que segrega, que limita, que controla, que retira a individualidade, pode conter a agressão? A agressividade que se encontra contida em penitenciárias, hospícios, favelas, é tanto assustadora quanto deprimente. Associar a agressividade, a miséria, a doença mental e a velhice a um tipo de edificação? Poder-se-iam descrever muitos problemas sociais e descortinar, atrás deles, um tipo de arquitetura, um caráter. Tentativas de agregação e sociabilidade em tais conjuntos vêm ocorrendo, historicamente, mas a morte social, mental ou física, é real. Mesmo que parte da sociedade venha tentando mudanças para reintegrar o homem, ainda estamos muito longe de soluções definitivas (COSTI, Marilice. Casas que matam. Disponível em: <http://www.iab-rs.org.br/colunas/artigo.php?art=105>. Acesso em: 20 abr. de 2006).

Naquela espécie de alegoria presente no Estorvo, em que se unem a pseudopobreza e o espírito de jardinagem do homem moderno, a 
casa de vidro trava uma batalha com a árvore que lhe fora plantada no interior, atitude que indica que a natureza também deve se curvar sob o poder daquele que tão bem domina a técnica, sendo a árvore, por fim, eliminada:

Também originalmente, o pátio circular no bojo da casa abrigava um fícus, cuja copa emergia no alto da pirâmide frustrada. Sucedeu que a casa, quando ficou pronta, começou a abafar o fícus que, em contrapartida, solapava os alicerces com suas raízes. $\mathrm{O}$ arquiteto e o paisagista foram convocados, trocaram acusações, e ficou patente que casa e fícus não conviveriam mais (BUARQUE, 1991, p. 15).

Nesse embate, os dois especialistas (arquiteto e paisagista; atentemos novamente à atuação das especialidades) são convocados a resolver o destino da casa, já que suas áreas de especialização, além de não dialogarem, conforme seria desejável, ainda entram em franco conflito. Assim como a árvore servira temporariamente à realização de um projeto (no sentido estrito), do mesmo modo a relação com as plantas do jardim, e mesmo com a floresta próxima, é a do uso sem envolvimento dos afetos: os cuidados se voltam todos, primordialmente, para a estrutura premiada de vidro e aço. O próprio conhecimento que a proprietária da casa de vidro tem da vegetação local é resultado de pesquisa, ou seja, ainda que demonstre algum interesse pela natureza lá fora, esse interesse é vivenciado de modo enciclopédico e disciplinar: "Tendo feito estágio no jardim botânico, minha irmã gosta de andar pelo arvoredo ao largo da casa, podendo distinguir o ipê do carvalho, da oiticica, do jequitibá ou da maçaranduba." (BUARQUE, 1991, p. 15).

O estágio e o projeto bem se alinham a uma ampla postura de planejamento - da vida - que costuma ter fim e objeto no próprio planejamento e que toma sob seu jugo a natureza. Do mesmo modo que, no caso daquela "arquitetura premiada", o alvo parece ser nada mais que a própria premiação. "Apreciar" a natureza passa a ser um "trabalho" de especialistas, atitude totalmente avessa ao devotamento romântico e mesmo indiferente às atuais preocupações 
ecológicas ou de sustentabilidade - ainda que por vezes o discurso o escamoteie:

Mas hoje, com o sol a pino e sem uma brisa sequer, minha irmã está para dentro e as folhagens não jogam; cada folha é um exemplo de folha, com seu verde-escuro à luz e seu contraverde-claro à sombra. Hoje é como se o jardim estivesse aprendendo arquitetura (BUARQUE, 1991, p. 15-16).

O pensamento que jaz nas entrelinhas é o de que o mundo vegetal aí está para uso do homem, do mesmo modo que o vidro e o aço, materiais que compõem, de agora em diante, o seu novo habitat. O que não se adapta ao projeto é simplesmente descartado. Diria Adorno: sem profundidade; diria Benjamin: sem experiência; Bauman acusaria: ausência de humanidade. 0 narrador faz o seu comentário sobre a casa de vidro:

Eu sempre achei que aquela arquitetura premiada preferia habitar
outro espaço. A casa livrou-se do fícus, mas nem assim parece satis-
feita com o terreno que lhe cabe, o jardim que a envolve toda, o limo
que pega nas sapatas de concreto, a hera que experimenta aderir aos
vidros. Nessa disputa o jardineiro tomou as dores da casa, e passa
os dias arrancando a hera, polindo o concreto, podando o que vê
pela frente. Um dia, tomado de cólera, saiu revirando os canteiros,
eliminou as hortênsias, e teria reduzido o jardim a um campo
de golfe, se minha irmã não interviesse (BUARQUE, 1991, p. 15).

Personificada desde o início, a casa parece querer sugar a vida do jardim, e para isso conta com o auxílio do jardineiro, que da sua romântica função de amigo das rosas passa direto a defensor da estrutura de concreto, vidro e aço. Aqui também a técnica (engenharia, arquitetura, paisagismo, jardinagem) é perturbada pela espontaneidade da natureza, mas a pirâmide de vidro, graças à sanha exterminadora do jardineiro, vence, sobrepujando as plantas que crescem ao redor. 
Todavia a contenda ainda não terminou, porque a derrocada do lar transparente não se percebe somente na sua estrutura material, mas principalmente por meio do outro distúrbio que chega sub-repticiamente e toma os seus membros. No filme baseado no livro, o diretor Ruy Guerra carregou nas tintas para a caracterização da sobrinha do narrador, especialmente no aspecto monstruoso de sua expressão facial. No romance, instigada pela mãe a cumprimentar o tio, a criança o faz simulando o ato de sacar dois revólveres, que descarrega sobre ele. A menina catalisa e canaliza um mal estar generalizado, resultante da convivência impossível de uma família esboçada em moldes tradicionais, o dinheiro e suas benesses mais diretas podendo, apenas até certo ponto, suster as aparências. As relações são todas de superfície; os afetos, minados pela força do dinheiro.

A irmã do narrador fala sobre a situação deplorável da mãe idosa:

Diz que mamãe tem andado tão sozinha, nem empregado ela quer, só tem uma diarista que às terças e quintas vai lá, mas diarista mamãe acha que não é companhia. O ideal seria contratar uma enfermeira, mas enfermeira mamãe acha que cria logo muita intimidade, e qualquer hora mamãe pode levar um tombo, porque anda enxergando cada vez pior (BUARQUE, 1991, p. 17).

A cada vez que a irmã assina um cheque pagando as despesas do irmão, de modo quase automático um copeiro traz até ele uma bandeja com o telefone, para que, em retribuição, cumpra uma obrigação aparentemente impossível de ser realizada: falar com a mãe. A tentativa de dar o telefonema, isenta de afeto, é tacitamente barganhada entre o narrador e a irmã, e tem o valor da subsistência daquele.

A pirâmide de vidro, desejada ilha de segurança cercada de portões e guaritas, é invadida, a um tempo, pelo descontrole das plantas ao redor e também pela miséria periférica, a despeito de todo o sistema de vigilância. A mulher tem as joias roubadas pelo próprio irmão, e a casa, posteriormente, é saqueada por um bando que a estupra, mortificando a família e ferindo os empregados. 
A cena violenta será lembrada repetidas vezes pelo marido, que ameaça a cada vez contar de novo ao cunhado o que presenciara. No entanto, falta ao seu relato um sentimento verdadeiro que o anime, e ele seguidamente desiste de narrar, antes mesmo de começar.

A mesma fissura se percebe na sua relação com a mulher e a filha. Tanto que, ao entrar no quarto do casal, o narrador chega a se surpreender com os lençóis amarfanhados: "eu jamais pudera imaginar que minha irmã e o marido dormissem no mesmo quarto" (BUARQUE, 1991, p. 59). Invasor naquele território, como aliás em todos os outros, ele irá naturalmente se refugiar no antigo sítio da família. Pelo tipo de sensação que, ao encaminhar-se para ali, relembra, percebe-se que o abrigo que involuntariamente encontra é antes na memória de experiências vividas na infância:

\begin{abstract}
Numa curva intensa para a direita, sinto o ombro do meu vizinho de banco pressionando o meu, e rio por dentro. Rio porque me lembro de quando íamos para o sítio de carro com meus pais, eu e minha irmã no banco traseiro. Curva para o meu lado, e eu jogava o corpo para cima dela, fazendo 'ôôôôôôô'. Curva para o lado dela, e era ela que caía para cá: 'ôôôôôôô̂'. A lembrança me bate com tanta força que chego a sentir o cheiro da cabeça da minha irmã (BUARQUE, 1991, p. 65).
\end{abstract}

Ao cruzar as barreiras do sítio, ele abala os estatutos de dentro e fora, interior e exterior, presente e passado, e traz à tona uma estranha percepção da ideia de pertencimento, ilustrativa da sua condição de elemento ameaçador numa sociedade obcecada por segurança: "Sinto que, ao cruzar a cancela, não estarei entrando em algum lugar, mas saindo de todos os outros. Dali avisto todo o vale e seus limites, mas ainda assim é como se o vale cercasse o mundo e eu agora entrasse num lado de fora" (BUARQUE, 1991, p. 24, grifos meus).

Fora dali, em meio à sociedade dita organizada, ele já era refugo; lá mesmo estava fora, estando contudo dentro. Ao sair daquele dentro que não o comporta, ele evade portanto de um mundo inteiro, penetrando um fora que, para ele, passa agora a ser o dentro. É ali 
que encontra seus iguais, outros estorvos sociais como ele, embora nenhum sentimento os irmane e nenhuma comiseração ou revolta, aparentemente, toque-os.

Ele é parte do refugo indiferente que assiste a tudo, inclusive à sua própria varredura. O sítio passa de paisagem da memória da infância a refúgio do dejeto humano circundante: o caseiro velho, pobre e negro, as crianças órfãs, que vivem ao léu, os plantadores de maconha, os bandidos, os traficantes, os assassinos, os policiais e ele próprio. É o seu contingente que expõe o avesso das utopias modernas e contemporâneas de ordem e segurança: vidas desperdiçadas, lixo humano que a um tempo justifica e ameaça as estruturas de vidro e as barreiras de aço. 


\section{REFERÊNCIAS}

ADORNO, Theodor W. Educação após Auschwitz. Tradução Wolfgang Leo Maar. Disponível em: <http://orbita.starmedia.com/ novosdebates/adorno/adorno12.htm>. Acesso em: 20 abr. 2006.

BARTHES, Roland. A câmara clara: nota sobre a fotografia. Tradução Júlio Castañon Guimarães. Rio de Janeiro: nova Fronteira, 1984.

BAUMAN, Zygmunt. Modernidade e ambivalência. Tradução Marcus Penchel. Rio de Janeiro: Jorge Zahar, 1999.

BAUMAN, Zygmunt. Vidas desperdiçadas. Tradução Carlos Alberto Medeiros. Rio de Janeiro: Jorge Zahar, 2005.

BAUMAN, Zygmunt. Amor líquido. Tradução Carlos Alberto Medeiros. Rio de Janeiro: Jorge Zahar, 2004.

BAUMAN, Zygmunt. Comunidade. Tradução Plínio Dentzien. Rio de Janeiro: Jorge Zahar, 2003.

BENJAMIN, Walter. Documentos de cultura, documentos de barbárie: escritos escolhidos. Tradução Celeste H. M. Ribeiro de Sousa et al. São Paulo: Cultrix, 1986.

BENJAMIN, Walter. Magia e técnica, arte e politica: ensaios sobre literatura e história da cultura. Tradução Sergio Paulo Rouanet. São Paulo: Brasiliense, 1993.

BRANDÃO, Carlos Antônio Leite. A arquitetura entre o renascimento do moderno e o luto da modernidade. Disponível em: <http://www.arquitetura.ufmg.br/ia/moderno.html >. Acesso em: 20 abr. 2006.

BUARQUE, Chico. Estorvo. São Paulo: Companhia das Letras, 1991. 
CARVAlHO, José Augusto. Pena de morte para os inocentes. Você, Vitória, n. 49, p. 23, set. 1997.

CÉSAR, Ligia Vieira. Poesia e política nas canções de Bob Dylan e Chico Buarque. São Paulo: EDUFSC/Estação Liberdade, 1993.

COSTI, Marilice. Casas que matam. Disponível em: <http://www.iab-rs. org.br/colunas/artigo.php?art=105>. Acesso em: 20 abr. de 2006.

DERRIDA, Jacques. A farmácia de Platão. Tradução Rogério da Costa. São Paulo: Iluminuras, 1991.

ELIAS, Norbert. Os estabelecidos e os outsiders: sociologia das relações de poder a partir de uma pequena comunidade. Tradução Vera Ribeiro. Rio de Janeiro: Jorge Zahar, 2000.

ESTORVO. Direção: Ruy Guerra. Produção: Bruno Stroppiana; Bruno Cerveira. Intérpretes: Jorge Perrugoría; Bianca Byington; Leonor Arocha; Tonico Oliveira; Xando Graça; Susana Ribeiro; Ataíde Arcoverde; Aurora Basnuevo; Cândido Damm; Manuel Romero; José Antônio Rodriguez; Verônica Lynn. Produtores executivos: Jom Tob Azulay; Miguel Mendoza. Direção de fotografia: Marcelo Durst. Roteiro: Ruy Guerra; Chico Buarque. Música: Carlos Alberto Lopes; Branco Neskov. Sky Light, c 2000. 1 DVD (95 min), full screen, color., legendado.

FARIA, Alexandre. Literatura de subtração: O homem côncavo. Disponível em:<http://chicobuarque.uol.com.br/>. Acesso em:24 jun. 2006.

FERNANDES, Rinaldo de. Chico Buarque do Brasil. Rio de Janeiro: Garamond, 2004.

KLÍMA, Ivan. Amor e lixo. Tradução Eduardo Francisco Alves. Rio de Janeiro: Record, 1993. 
LEE, Rita. Ovelha negra. Fruto Proibido. Rio de Janeiro: Som Livre, 1975. LP, lado B, faixa 4.

MASSI, Augusto. Artigo na Folha de São Paulo, 02/12/95. Disponível em: <http://chicobuarque.uol.com.br/>. Acesso em: 05 out. 2007.

MOREIRA, João Luís Salgueiro. Animal farm e Fazenda modelo / George Orwell e Chico Buarque: duas faces da mesma moeda. Textos e pretextos, Lisboa, nº 7, 2005, p. 50-59.

OLIVEIRA, Bernardo Barros Coelho de. A filosofia enquanto crítica literária: O Baudelaire de Benjamin, e vice-versa. Disponível em: <http://test.scielo.br/scielo.php?script=sci_arttext\&pi$\mathrm{d}=\mathrm{S} 1517-106 \mathrm{X} 2005000100003 \& \operatorname{lng}=\mathrm{en} \& \mathrm{nrm}=\mathrm{iso} \& \mathrm{tlng}=\mathrm{pt}>$. Acesso em: 20 abr. 2006.

ORWELL, George. 1984. Tradução Wilson Velloso. São Paulo: Editora Nacional, 1996.

PLATÃO. Fedro. Tradução Pinharanda Gomes. Lisboa: Guimarães e Cia Editores, 1981.

RIBEIRO, Carlos. Romance do simulacro. In: FERNANDES, Rinaldo de. Chico Buarque do Brasil. Rio de Janeiro: Garamond, 2004.

SCHWARZ, Roberto. Um romance de Chico Buarque. In: . Seqüências brasileiras: ensaios. São Paulo: Companhia das Letras, 1999, p. 178-181.

SOARES, Luiz Felipe Guimarães. Estorvo e outros estorvos. Florianópolis: UFSC, 1996. (Dissertação de Mestrado).

TITÃS. Miséria. Õ Blésq blom. (Rio de Janeiro: WEA, 1989). LP, lado A, faixa 2. 



\section{BENJAMIM: O MODELO E A MÁQUINA}

Dos romances de Chico Buarque ditos "de maturidade", Benjamim é considerado, por alguns estudiosos, o mais incompreendido, algo que talvez se explique pelo modo especialmente incômodo como atua - ou deixa de atuar - nessa narrativa, o tempo, além de que ou graças a que a ação de cada um dos seus personagens se marca sempre por um déficit de arbítrio e, no polo oposto, pela ação violenta.

Aliandro, Ariela, Benjamim e Jeovan, cada um deles parece, a princípio, imobilizado ou movido por um motor que conduz ora à indiferença e à covardia, ora ao uso da força. Trata-se do movimento de uma engrenagem maior que eles, verdadeira roda viva a conduzi-los, o que aponta, antes de tudo, para o tempo como grande personagem da trama.

Essa engrenagem, que não dispensa a organização de uma aparelhagem externa para vigilância e domínio dos corpos, funda-se principalmente a partir das redes lançadas pelo inconsciente de cada um para a limitação dos movimentos de resistência àquela e a seus efeitos. Com suas máquinas fotográficas e câmeras filmadoras, engessados em poses ou na luta pela subsistência, os personagens caminham cegos em meio à miséria que se acerca: são protagonistas por entre o elenco de apoio a uma sociedade desigual.

o ex-modelo fotográfico Benjamim Zambraia, que dá nome ao romance, como que une em si dois tempos: o de sua juventude, em que as ligações afetivas - ao menos idealmente - eram estabelecidas 
para durar, e a atualidade, em que vige, de acordo com Bauman, "a misteriosa fragilidade dos vínculos humanos, o sentimento de insegurança que ela inspira e os desejos conflitantes (estimulados por tal sentimento) de apertar os laços e ao mesmo tempo mantê-los frouxos" (BAUMAN, 2004, p. 8).

É Benjamim, como veremos, o portador de um dos "aparelhos" centrais na constituição daquela esfera maquínica de vigilância e autovigilância. E assim, um arsenal que parece, à primeira vista, algo secundário, revela sua importância estruturante em cada um dos romances de Chico Buarque. Se o olho mágico de Estorvo configura um modo de ver que marca todos os eventos da narrativa, em Benjamim a câmera imaginária de Zambraia e o relógio interior de Ariela são a causa (e ao mesmo tempo o efeito) de uma opção de recorte daquela realidade criada, enquanto o que chamaremos, em Budapeste, de "máquina de escrita", será a realização - e também os resultados - de um processo de autotextualização ou transformação de si próprio em máquina de escrever, no sentido que lhe dá Derrida em Papel-Máquina. Cada um desses "instrumentos” é mais que mero recurso temático, o que equivale a dizer que extrapola as funções que comumente lhes são aderidas, como: revelar uma presença sem que se desfralde a presença de quem observa (no caso do olho mágico e do panóptico), registrar ou documentar (a câmera filmadora) e produzir textos (a máquina de escrever).

No romance Estorvo, o percurso do narrador revelou-se um caminho em busca ou em fuga (de si e/ou de outrem), um longo caminhar fora de foco, conturbado pela turva visão inicial a que, na sua imaginação, ele faz aderir a qualidade de visibilidade recíproca, e que, ao final, revela-se mais que um modo de ver, configurando o próprio modo de narrar. A aura maquinal extrapola o jogo retórico, e o olho mágico que inaugura a acontecimentalidade narrativa propaga-se no olhar embaciado que conduz o leitor por todo o texto. A narrativa é ela própria, na sua realização final enquanto escrita, uma visão ou um conjunto de espectros que se movem em sucessão, é ela mesma um grande "olho mágico" que se oferece ao leitor, o adje- 
tivo desdobrando-se ali enfim por outras acepções, além daquela primeira a que remete, cotidianamente, a expressão.

Em Benjamim a "opção" pelo relógio e pela máquina filmadora que se acoplam ao corpo acaba por marcar também o modo narrativo, em seus avanços e retardos. O narrador - e mesmo o texto podem ser vistos como máquinas filmadoras, em seus cortes e seleções cinematográficos, traços que, aliás, concorreram para que o romance fosse rapidamente transformado em roteiro para o cinema.

Em Benjamim a "opção" pelo relógio e pela máquina filmadora que se acoplam aos corpos acaba por marcar também o modo narrativo, em seus avanços e retardos. O narrador, e mesmo o texto, podem ser vistos como máquinas filmadoras, em seus cortes e seleções cinematográficos, traço que aliás concorreu para que o texto fosse rapidamente transformado em roteiro para o cinema.

Tanto em Benjamim quanto em Estorvo e em Budapeste a maquinalidade não é meramente demonstrativa ou crítica de uma reificação do homem nas sociedades capitalistas contemporâneas; ela agencia complexos de relações que podem desaguar em desejos e em atos violentos. Engrenados em maquinações políticas e maquinários sociais, os personagens vivem, amam, trabalham, sofrem, perseguem, fogem, matam e morrem, sendo o ex-modelo Benjamim Zambraia, em meio a essa engrenagem, como uma peça que trava, entrave que se explicitará sobretudo no contraste de seus modos de ação (melhor dizendo, de sua inação) com os de Ariela.

Na cena inicial do romance, aguardando por alguém em um restaurante, Benjamim se condói de um funcionário imaginário, que ele quase que visualiza tendo de recolher as guimbas de cigarro que um cliente lançou no urinol, no banheiro masculino. o que parece, a princípio, um ato de consciência ética e social, descortina de imediato a inconsequência de muitas de suas ações contraditórias, e mesmo sua covardia, apesar das boas intenções que o levam a agir, mas que não têm força suficiente para fazê-lo concluir o ato: com as pontas de cigarro na mão e intencionando jogá-las no lixo, ele é surpreendido pela entrada de um outro cliente que vem usar 
o banheiro e cuja simples presença o imobiliza, enredando-o em pensamentos turbilhonados pela timidez, e ele termina por lançar no ralo da pia o lixo que retirara do urinol, passando o problema da guimba, do mesmo modo, a alguém mais adiante.

Na cena descrita acima, o ex-modelo aposentado acaba por agravar uma situação cujos causadores desconhecidos ele mesmo acusara de "fascistas": "Benjamim experimenta sepultar as guimbas pelo ralo da pia. Mas no fundo do ralo há uma cruz de ferro e elas entalam ali. Benjamim lava as mãos com o líquido da saboneteira fixa e volta ao salão" (BUARQUE, 2004, p. 9). "Lavando as mãos" ele se afasta da responsabilidade pelo ato que iniciou, sem conseguir livrar-se, porém, da culpa. Desse modo, segue acumulando sentimentos alimentados pela inércia e que, numa bola de neve, ainda mais a ampliam. É um dos momentos culminantes da má consciência desse personagem que tenta se redimir, sempre por vias tortuosas, de sua alienação e da covardia que tiveram graves consequências no passado.

Em outra ocasião Benjamim dispensa aos mendigos que habitam as cercanias de seu prédio uma arara de roupas, com um figurino completo e demodé, provavelmente restos de peças publicitárias de que participou um dia, como modelo fotográfico.

Abordado pelos mendigos, Benjamim entra no chafariz e cruza-o com água pelas canelas. Mas novos mendigos já o aguardam na outra margem, agitando farrapos do seu paletó, e o cortejo só faz engrossar-se até a entrada do seu edifício. Benjamim desvencilha-se da gravata, da camisa, dos sapatos com as solas meio descoladas, e sobe ao apartamento. Abre as três janelas, grita 'boa noite, Pedra!' e engasga, assaltado por um sentimento físico de euforia, não muito diferente de uma angústia na garganta. Arrasta um cabideiro pesado do quarto da criança até o corredor. É uma peça de madeira em feitio de pinheiro seco, cujos galhos sustentam casacos, japonas, sobretudos, cachecóis, chapéus. Encaixa-se com o trambolho no elevador, que desce lotado de travestis. Planta o cabideiro na calçada, assobia para os mendigos, atravessa o largo, o palmar, o chafariz, e refaz o seu percurso anterior a contrapelo (BUARQUE, 2004, p. 90). 
Logo a seguir "Toma o radiotáxi, e o que lhe parecia um carnaval de mendigos no largo do Elefante, reconhece agora como seu próprio ex-guarda-roupa circulando ao sol" (BUARQUE, 2004, p. 101). A pobreza é vista como o destino natural, lugar ideal de escoamento das sobras, um esgoto do que não tem mais utilidade - por enquanto os objetos indesejados (roupas em desuso, chapéus, rolos de filme), quiçá depois os próprios possuidores desses objetos, pessoas que por ora se acercam dos mendigos com medo ou, por outro lado, com atos de euforia egóica e pseudo-heróica, como é o caso de Benjamim ao dispensar as roupas.

Enquanto isso, do outro lado da cidade,

[Ariela] Lembra-se do cliente, que naquele minuto já poderia estar plantado diante do edifício, e atravessa em diagonal a praça que normalmente contornaria por causa dos mendigos. Por medo de assaltos Ariela não usa relógio, embora possua uns tantos em casa, guardados numa caixa de charutos no fundo de uma gaveta (BUARQUE, 2004, p. 13).

Surgindo como surge uma feia paisagem, que se evita contemplar, mas que é visível sempre e somente a uma certa distância, os pobres constituem, com sua existência, uma ameaça. Na verdade, não há como negar, a pobreza - e logo a seguir a mendicância - é o caminho natural de Benjamim e Ariela, em caso de decadência, assim como, na linha inversa, aos mendigos se seguem os assalariados, alternância de condições que a cena do transporte bem ilustra: "Em sincronismo com o furgão que arranca lotado de mendigos, o primeiro ônibus da manhã vem descarregar um magote de trabalhadores no largo do Elefante" (BUARQUE, 2004, p. 136).

$\mathrm{Na}$ distribuição das roupas do cabideiro, mais que a alegoria dos arroubos de um homem apaixonado ou o ato simbólico de deixar para trás um passado que não lhe cabe mais, nota-se uma sutil porém ameaçadora aproximação entre Benjamim e os mendigos, esses habitantes da camada imediatamente inferior àquela cujo status desfruta, por ora, o ex-modelo. Sobretudos, cachecóis, 
chapéus... Curiosamente, aquelas vestes, restos de uma cena em que foi preciso, um dia, "simular" o homem, todos os objetos supérfluos que antes habitavam a esfera da fantasia, passam então a desenvolver uma função utilitária, tendo apenas mudado de mãos: das de Benjamim para as dos mendigos que habitam o largo.

Benjamim encontrará depois os mendigos vestidos com o seu antigo figurino e, ironicamente, é o próprio ato de "generosidade" no dispêndio das sobras que faz surgir a ameaça, retornando, os contemplados trajados com os seus dejetos, para tomar-lhe o que mais houver. Se a roupa, um dos maiores índices de classe social, no capitalismo, escorrega com tanta facilidade e rapidez de um a outro, surge aí mesmo a possibilidade de que o oposto também se dêt. Ver o mendigo usando suas roupas desvenda incontinenti uma proximidade não imaginada entre as situações de ambos, o estabelecido e o outsider, para lembrar o binômio de Norbert Elias e suas explicações acerca da angústia de status que vem à tona com a sensação de que o sofrimento que desfila perante nós em breve pode ser nosso.

No estado de encantamento passional em que se encontra, Benjamim se livra daqueles pertences tão longa e cuidadosamente guardados como se tivesse perdido, num repente, o medo da miséria, fantasma que o vem assombrando e que o fizera, tempos antes, criar, como garantia para o futuro, sua própria aposentadoria. Naquele momento contudo nada disso parece importar. Mais adiante ele chega a jogar dinheiro fora, literalmente. Tendo presenciado o que deve lhes parecer um ato de desvario, os mesmos mendigos atacam depois Benjamim, certamente em busca de mais dinheiro:

Paga a corrida, as horas paradas, a gorjeta, e o dinheiro do cheque de G. Gâmbolo, que ele um pouco despreza, parece por isso mesmo

4 Os versos da canção "Negro amor", versão de Caetano Veloso e Péricles Cavalcanti para "It's all over now", de Bob Dylan, parecem invadir a narrativa, como pano de fundo: "O vagabundo esmola pela rua / vestindo a mesma roupa que foi sua” (COSTA, 1977). Na canção, como na cena descrita no romance, uma atmosfera nonsense resulta do modo como o vestuário, parcela da intimidade, muda repentinamente de usuário, tanto quanto da forma como a ameaça intrínseca de mudança de statusé desfilada pelas ruas, ou seja, pelo lugar mais público. 
reproduzir-se no seu bolso. Como fortuna de jogo ou do narcotráfico, como butim ou herança eventual, aquele é um tipo de dinheiro que pede para ser esbanjado. (...) À beira do chafariz, onde crianças peladas tomam banho, despe o paletó e atira-o para o alto. 0 paletó sobrevoa o repuxo, abre-se feito um pára-quedas e despeja uma chuva de dinheiro. Mendigos acorcundados surgem por detrás das árvores, mas as crianças agadanham as notas no ar como quem caça moscas (BUARQUE, 2004, p. 89-90).

Tendo presenciado o que deve lhes parecer um ato de desvario, os mesmos mendigos, conforme já dito, atacam depois Benjamim, certamente em busca de mais dinheiro:

\begin{abstract}
O primeiro tapa no flanco para Benjamim é quase sensual. Outra mão repuxa a gola da sua jaqueta e desnuda-lhe a nuca, como se abrisse caminho para fincar um cano de pistola. Agarram suas mangas e terminam por derrubá-lo com uma tração mais violenta. Sentado no chão, pronto para o golpe de misericórdia, Benjamim é despojado de sua jaqueta de tenista. Vê um molho de chaves, uma tesoura de unhas e o relógio de ouro caídos à sua volta, e vê dois vultos que escapolem, disputando a jaqueta virada pelo avesso. E na contraluz do largo reconhece o casal de mendigos, ela num smoking com as pernas arregaçadas, ele com um gorro de cossaco, recordação de um anúncio de vodca (BUARQUE, 2004, p. 109).
\end{abstract}

Os pobres são outsiders inclusive na narrativa, pela secundariedade de seu papel, e desfilam nos entornos da história de Benjamim e Ariela, constituindo uma espécie de consciência sombria, sempre à espreita (mais, ou menos, passiva ou incisiva) das sobras que aqueles lhes queiram lançar, ou do que consigam tirar-lhes. Benjamim, ao precisar livrar-se de algo - e tão somente nesses momentos -, lembra-se dos pobres, ainda que se trate de coisa totalmente inútil para aqueles, como o é o filme de sua "câmera" imaginária:

Então implora à câmera que o abandone de vez, e que saia sobre uns trilhos atrás da moça, e que se livre dos carretéis com a vida de Benjamim Zambraia, e que os atire aos pobres. E deseja que os pobres, que de tudo sabem tirar proveito, se enrolem na história de Benjamim Zambraia e desfilem fantasiados de múmias, e lancem 
serpentinas, e examinem os fotogramas contra o sol e deem risadas (BUARQUE, 2004, p. 12).

O desejo de alegrar os pobres com os restos de suas fantasias, que de um certo ponto de vista soa irônico, demonstra mesmo a completa alienação ${ }^{5}$ de Benjamim, despojado que vai sendo, aos poucos, da própria vida, pelo mecanismo mesmo com que tenta retê-la.

Essa alienação é a um tempo causa e efeito de suas opções desde a juventude, dentre elas aquela que parece a mais ingênua e sem consequências, mas que aponta incontestavelmente para seu modo de olhar o mundo e de interagir com ele: a adoção de uma certa "câmera filmadora" como um "sexto sentido" seu. Desse modo de olhar ao redor, como quem filma e é filmado, advém um estar sempre pela metade, uma incompletude na vivência dos fatos, como se o ex-modelo fotográfico fosse o tempo todo dirigido, resultando daí também o tipo de narrativa que é Benjamim. A vivência pequeno-burguesa que tivera um dia resulta em pobreza de experiência e em uma posterior aceitação indiferente de toda violência, reenviando às ideias daquele outro Benjamin, Walter.

Diante de cenas cuja força bruta passaria hoje despercebida por muitos, como a do transporte de uma girafa amarrada e coberta na carroceria de uma pick up para ser exibida numa gincana, Benjamim nada diz, não expressa sentimentos; apenas imagina uma vingança do animal contra aqueles que o conduzem e afirma, no silente comentário mínimo que é mais do narrador do que seu: "queria ver se ela escoiceava" (BUARQUE, 2004, p. 38-39). Em outro momento, assistindo à irritação de um dos rapazes que o levam à mesma gincana (para ser exibido como "uma pessoa famosa") com o fato de ter tido seu carro ultrapassado pelo estudante da equipe concorrente, e vendo o rapaz repelir de modo violento a namorada que

\footnotetext{
5 Entendemos esta palavra, com Derrida, de maneira "neutra": "tratar-se-ia de um 'estranhamento', de um Outro-Inconsciente maquinal, que nos enviaria de volta nossa própria fala, a partir de um lugar completamente diferente. Amor e ódio: a nova máquina instalaria uma outra explicação do corpo, do olho e da mão, do ouvido também, sob o comando de um corpo estranho, a lei, a ordem do Outro-Inconsciente" (DERRIDA, 2004, p. 144).
} 
o abraça, Benjamim “compreende que é assim mesmo" (BUARQUE, 2004 , p. 38). Vai aprendendo assim, em seus raros contatos com o mundo exterior ao seu apartamento, no qual durante quase todo o tempo se encerra solitário, a aceitar sem contestação um mundo de modos diversos aos que um dia conheceu; a ausência de resistência constitui mesmo um primeiro passo e a prova de sua adaptação. Como se recompusesse com sua figura, a cada vez, o contexto para uma nova fotografia comercial, o modelo fotográfico Benjamim Zambraia aterrissa nesse tempo indiferente, arrastado por uma vontade estranha à sua, como uma espécie de novo morto vivo. A tônica das relações é a indiferença, e é com indiferença que ele logra se adaptar a essa realidade, pela qual caminha sem segurança.

Envoltos, cada um a seu modo, por essa rede de forças que fará com que se cruzem as suas vidas, estão o ex-modelo, a corretora de imóveis Ariela, o político Aliandro, o vendedor de automóveis Zorza e o ex-policial Jeovan. Curiosamente é Jeovan, aquele que se encontra verdadeiramente paralisado (tetraplégico, deitado em casa), a válvula motriz de um emaranhado de vetores de força. É ele quem faz com que se movimente a trama narrativa: marido enciumado de Ariela, o ex-policial solicita secretamente, ao tio, que elimine os pretendentes dela. Imóvel, enquanto a mulher negocia imóveis, ele insufla os acontecimentos, como se fosse uma espécie de autor ou mesmo um deus paralítico (Jeovan/Jeová).

O texto se perfaz assim num constante jogo entre móvel e imóvel: Ariela é corretora de imóveis, e seu namorado, Zorza, revende automóveis. Enquanto isso o marido, paralisado em casa, orquestra sutilmente a narrativa, e Benjamim, o estático, serve como ponto de cruzamento ou condução daquelas forças de sedução e vendeta.

É habito de Ariela, ao chegar do trabalho, narrar a Jeovan as cenas de assédio e mesmo os atos de violência sexual que vez ou outra sofre por parte dos pretensos locadores dos imóveis que se dispõe mostrar-lhes. Algumas cenas são fantasiadas por ela e, às vezes, assédios que deveras sofrera são incrementados nas histórias que conta para o marido inválido: 
Acendeu a luz e, face a face com Jeovan, começou a contar como um homem narigudo torcera seu braço e se deitara por cima dela. Recitou o episódio pausadamente, e viu as lágrimas que brotavam dos olhos de Jeovan, e se acumulavam, e formavam dois poços sobre as suas olheiras, porque ele chorava na horizontal. Por fim transbordaram, não em gotas, mas como dois filetes fluindo sem cessar da cavidade dos olhos em direção aos ouvidos. E Ariela chorou também, por achar delicadas como nunca achara as feições de Jeovan, e por reparar no quanto era lisa, juvenil, a pele dele quando bem escanhoada. Desejosa de prorrogar aquele momento, e já tendo contado como o judoca depois de tudo fugira atarantado, fez com que ele regressasse e tornasse a abusar dela, e adicionou crueldades que ele não praticara (BUARQUE, 2004, p. 150-151).

Paradoxalmente, Jeovan abomina as mesmas cenas eróticas de que se alimenta e que, afinal, retiram o ex-policial do limbo depressivo em que se encontra, levando-o a arquitetar diversos planos de vingança, um dos quais representará, na narrativa, o clímax da ação, sendo ação, obviamente, o maior objeto de desejo de alguém que já não pode se mover. Jeovan planeja assim a vingança que inclui, por engano, o assassinato de Benjamim Zambraia, imiscuído entre os possíveis amantes de Ariela.

Trata-se de dois jogos perversos, o da sedução e o da vingança. Neste, os passos traçados só serão conhecidos a posteriori, quando se desvenda o porquê do assassinato de Benjamim. Naquele, as regras são tacitamente elaboradas entre o casal.

Percebendo o interesse do marido, para quem a sexualidade, após o acidente que o paralisou, só pode ser mesmo teórica, Ariela alimenta o imaginário de ambos e supre as necessidades do parceiro com o desenvolvimento verbal de suas próprias fantasias sexuais, como uma espécie de Sheherazade. É assim que Jeovan se mantém vivo, apesar do perene estado depressivo, lembrando o personagem do filme Carne trêmula, do cineasta espanhol Pedro Almodóvar: o policial inválido cuja excessiva honestidade da esposa tem sua máxima expressão no fato de fazê-lo ouvir a confissão do seu rela- 
cionamento extraconjugal com o homem que desferira no marido, no passado, os tiros que o puseram na cadeira de rodas.

Um mais-além da sexualidade permitida e costumeira se insinua já no início da narrativa. A descrição que o narrador faz de Ariela, de suas roupas e do modo como acompanha os "clientes", quando ainda não foi revelada ao leitor a sua profissão, lança a dúvida: seria ela corretora ou prostituta?

Pela sua experiência, clientes atrasam-se numa média de doze minutos, e existe uma tolerância tácita de vinte minutos de parte a parte. Tal média não leva em conta os casos de forfait, por conta de trotes e desistências, que Ariela calcula em quinze por cento. Ela nunca faltou, em última instância manda uma colega em seu lugar. Mas aconteceu-lhe uma vez de chegar ao encontro com atraso de meia hora e perder a cliente - era uma mulher. [...] Com um pé na calçada e outro na lanchonete, Aliandro Esgarate vê aproximar-se a mulher de calça jeans e blusa de crochê. Vê quando ela pára em frente à galeria, e confirma que é esguia e um pouco mais jovem do que lhe fizera supor a voz no telefone. [...] Deve ser uma novata, pois afunda o braço na bolsa e bole lá dentro falando 'as chaves, as chaves' com um açodamento desnecessário. [...] Abre espaço e posta-se na entrada do elevador como uma garça na lagoa, deixando uma perna suspensa contra a célula fotoelétrica. Retém a porta até a chegada de Aliandro, que sente o dedo de Ariela Masé roçar seu peito a caminho do botão do vigésimo andar (BUARQUE, 2004, p. 14-15).

Nesse ponto a narrativa instaura uma ambiência propícia à imaginação erótica. A ambiguidade instaurada por artifícios de linguagem se desenvolve depois, ao longo do texto, graças aos modos, roupas e desejos indecidíveis, constitutivos da ingênua sedução de Ariela. Por enquanto o leitor não pode simplesmente qualificá-la. Ela é ora o veículo, ora a válvula motriz de fantasias próprias e de outrem, é aquela que as enreda e movimenta, uma profissional treinada para lidar com o imaginário dos mais variados clientes, aquela que, por meio da palavra, se esforça por fazer com que se adeque aos anseios de cada um deles um dos objetos em oferta.

Como costuma acontecer, nas empresas de corretagem, com 
os vendedores menos experientes, o conjunto de imóveis que Ariela recebe para tentar negociar, a sua "carta", é a pior possível, composta de casas, apartamentos e lojas de localização ruim ou com outras características que muito raramente agradam aos potenciais compradores, surgindo assim, mais uma vez, a analogia do universo da corretagem com o do comércio sexual, a partir da ideia de eterna irrealização dos desejos, sempre adiados e, por isso mesmo, ampliados em sua força explosiva.

E, em se tratando de imóveis, a pura imobilidade das formas, ou seja, uma ausência de reformas, é índice de decadência. A arquitetura do apartamento de Benjamim (a escolha da vista para a pedra: opacidade, peso e contravista), assim como a da maioria dos imóveis que Ariela tenta negociar, expõe a decrepitude de que todos fogem. Como este:

Ao subir com o cliente para o décimo oitavo andar, Ariela recitara sem muita ênfase o texto que, afinal, revelou-se inócuo: haviam emparedado as três janelas do apartamento. Ela acendeu as lâmpadas fluorescentes, acionou os exaustores, os aparelhos de ar-condicionado, e ainda ensaiou cantarolar alguma coisa, mas o cliente escafedeu-se, nem se deu ao trabalho de entrar. Agora Ariela desce sozinha num elevador cheirando a inseticida, rangedor, moroso: décimo terceiro, décimo segundo, décimo andar, pausa, e a porta abre-se ao meio, que nem cortina de teatro (BUARQUE, 2004, p. 57-58).

E mais este:

Ariela abre os braços para apresentar a sala, mas não sabe o que falar e olha para os clientes, e olha para o assoalho de tábuas empenadas. Indica a escada que leva aos quartos, acompanha os rapazes até o terceiro degrau, mas sente um princípio de náusea e prefere esperá-los embaixo. Roda pela sala e fecha a porta da cozinha, que exala um cheiro de bicho morto. Meio desequilibrada, tenta de novo subir a escada, ouve os rapazes que conversam baixinho num dos quartos, recua, sai à calçada e respira fundo. Vê um táxi que acaba de partir, estende a mão, mas o carro já vai longe e está ocupado (BUARQUE, 2004, p. 49). 
A imobilidade de Benjamim, metonimicamente reforçada pela descrição de seu convívio íntimo com a Pedra do Elefante, que lhe empareda o apartamento - "Há o cheiro da Pedra em Benjamim, que à saída do quarto fita Ariela, empedernido; é tão presente a Pedra naquela sala que, se Benjamim viesse a emparedar a janela, parece a Ariela que a Pedra ficaria do lado de dentro" (BUARQUE, 2004, p. 158) -, é como que insuflada ou reiterada pela característica principal de sua antiga profissão: a busca da pose, que irá se fixar em imagem através da fotografia. Sobre o ato de posar para uma foto, diz Roland Barthes:

Imaginariamente, a Fotografia (aquela de que tenho a intenção) representa esse momento muito sutil em que, para dizer a verdade, não sou nem um sujeito nem um objeto, mas antes um sujeito que se sente tornar-seobjeto:vivoentãoumamicroexperiênciadamorte(doparêntese): torno-me verdadeiramente espectro (BARTHES, 1984, p. 27).

Quanto a Benjamim, trata-se de uma existência que, longamente treinada para a representação, ainda se nutre do artifício da aparência e da pose típicos da sua juventude, ressentindo-se dos novos modos de representar, o que por extensão envolve as demais "estratégias" de relação interpessoal:

Ele sabe que G. Gâmbolo não vem. Mesmo assim, despeja o mate no copo longo cheio de gelo, repõe os óculos sem grau e acende o cigarro, que fuma sem tragar. Pelo tom da secretária, presume que ela nem sequer transmita o recado ao patrão. O que é uma pena, pois G. Gâmbolo encontraria um Benjamim em ótima forma. Recordaria imediatamente a imagem de Benjamim Zambraia nos outdoors do ano retrasado: Cigarros Knightsbridge (BUARQUE, 2004, p. 33).

Mesmo pressentindo a quebra do compromisso por parte daquele que o dirigira no passado, ele ainda espera e, enquanto isso, compõe toda uma cena, repleta de elementos fake, como se posasse para uma fotografia.

A relação de Benjamim com a própria imagem é bastante diferente da de Ariela, mais bem experimentada num mundo de 
cotidiana representação (dinâmica e não estática) e comércio de imagens, por onde passa, inclusive, o trabalho de corretora:

E Ariela habituou-se a baixar os olhos na presença do Zorza, visto que o silêncio não sustenta o peso de longos olhares recíprocos, exceto nos filmes de amor, e nem mesmo nos filmes de amor porque ali, quando cessa o diálogo, o diretor sempre coloca uma música (BUARQUE, 2004, p. 41).

Preso a um passado de foto e pose, portanto a uma autorrepresentação imóvel, Benjamim não se integra a uma sociedade do tipo Big Brother, em que imperam as câmeras que filmam, captando os movimentos. A filmadora foi contudo o instrumento adotado por ele, ainda que se mostre um instrumento de domínio impossível, como se verá.

De um modo contraditório para aqueles que, como Ariela, já nasceram nessa sociedade, parece simples anular momentaneamente todo e qualquer movimento para que seja selecionado, do seu tempo, apenas um flash. É assim que, convencida por G. Gâmbolo de que poderia ser modelo, Ariela aceita o convite para fazer um teste no qual de repente revela toda sua "fotogenia", como se tivesse frequentado desde sempre os estúdios fotográficos:

[Ariela] Retornou ao gabinete, provou uma túnica de seda furta-cor e relaxou-se, riu, emocionou-se, espantou-se, ofendeu-se e ficou triste, conforme as instruções do fotógrafo, depois por conta própria mordeu o lábio inferior, com um olhar sugestivo (BUARQUE, 2004, p. 125-126. Conteúdo dos colchetes inserido por mim).

Além de circularem em meio a diferentes modos de representação e autoapresentação, Benjamim e Ariela trazem em si mesmos as engrenagens em que estão envoltos e os aparelhos imaginários que criaram para auxiliar no governo de suas vidas. No entanto, mais que a simples acoplagem imaginária de máquinas aos corpos, como veremos, é perceptível ainda uma verdadeira naturalização do corpo maquinal. A câmera que Benjamim imagina no ventilador do teto 
do restaurante, por exemplo, similar às que nos vigiam a todos cotidianamente, tem uma outra versão implantada no seu cérebro: "Mas quando entra no Bar-Restaurante Vasconcelos, ainda o incomoda a suspeita de uma câmera, talvez acoplada ao bico do ventilador de longas pás que gira no teto" (BUARQUE, 2004, p. 8). O vício de profissão desenvolvido pelo modelo fotográfico indica a vigilância interiorizada e a culpa que, veremos, carrega com relação a atos e, principalmente, a omissões do passado.

A maquinalidade é assunto de que trata, em vários momentos de sua obra, o filósofo argelino Jacques Derrida. Seu questionamento sobre a completa ignorância do homem comum acerca da máquina (no exemplo citado adiante, o computador) e de como ela funciona traz um pequeno salto - mas de grande importância - que faz falta ao pensamento mais disseminado dentre aqueles que se dedicam a entender, hoje, as tecnologias como um todo:

Esse segredo sem mistério constitui a marca frequente de nossa dependência para com muitos instrumentos da tecnologia moderna, de que sabemos nos servir, conhecemos sua utilidade, sem saber o que se passa com eles, neles, do lado deles, e isso daria muito a pensar sobre a nossa relação com a técnica hoje, sobre a novidade histórica dessa experiência (DERRIDA, 2004, p. 143).

A tentativa de Benjamim de dominar certas cenas, ao adotar a câmera filmadora a qual depois não consegue governar, bem demonstra essa defasagem, a um tempo humilhante e arrogante, diante da técnica. De um modo mais geral, pode-se afirmar que não basta aderir às novidades da tecnociência ou pensá-las somente perpassando informações já correntes. É salutar, num movimento ambivalente, buscar conhecê-las, penetrar os seus meandros, estranhando-as contudo. É preciso ao homem interrogar insistentemente suas próprias criações, mantendo sob observação cada inovação tecnológica ou científica como algo sempre sujeito (enquanto invenção humana) à reavaliação responsável do seu criador.

A plena abertura "bem intencionada" às novidades que era 
possível conseguir nos campos técnico e científico em cada época, levadas a seu grau máximo de eficácia, já tiveram resultados nefastos como o Shoah na Alemanha nazista, para irmos direto a um exemplo extremo do que é capaz um grande e rápido avanço tecnológico quando apontado pelo afã de poder para objetivos meramente políticos, ainda que de algum modo o discurso o escamoteie. Sem delírios persecutórios contudo é necessário estar alerta às ameaças insurgentes, embora saibamos que, em algumas partes do globo, outros novos genocídios se dão neste exato momento de escrita e leitura.

De um modo ou de outro, na escrita ficcional - ela própria um efeito de artifício - habitam os idealizadores e os usuários do maquinário de cada época, personagens que o fabricam e outros que são por ele fabricados. As técnicas e os instrumentos da dita sociedade disciplinar, por exemplo, alimentaram o imaginário de grande parte da ficção dita moderna, assim como, no estágio atual, os signos da vigilância, ligados à delimitação do tempo, interiorizaram-se, imergindo como traço e modo de diversos personagens da literatura contemporânea.

O anúncio prévio e sutil da fase atual da sociedade panóptica foi feito por Michel Foucault no seu estudo acerca dos modos de vigilância ainda dos idos tempos modernos. A complexa cameragem presente em Benjamim não deixa de seguir, ela também, um certo modelo panóptico, adaptado porém a esse novo contexto. Pode-se afirmar que hoje o principal panóptico do homem é o seu inconsciente e que a naturalidade com que os objetos maquinais aparecem ligados aos corpos, a exemplo do que acontece no romance Benjamim, é sinal da atualização daqueles mecanismos de poder.

Ao adotar, na adolescência, para sua melhor atuação junto ao grupo, a tal "câmera invisível", Benjamim alcança de repente uma superioridade imaginária, ao olhar para um mais-além das situações imediatas em que se encontrava, tendo-se presenteado, assim, com um outro ponto de vista, que não era nem o seu, nem o de seus colegas. Pensando no início ter adquirido o 
instrumento por meio do qual exercitaria a sua indiferença ante os demais, rapidamente ele passa a ser não mais a estrela intocável que desejara, mas sim a vítima preferencial das filmagens:

Fez-se filmar durante toda a juventude, e só com o advento do primeiro cabelo branco decidiu abolir a ridícula coisa. Era tarde: a câmera criara autonomia, deu de encarapitar-se em qualquer parte para flagrar episódios medíocres, e Benjamim já teve ganas de erguer a camisa e cobrir o rosto no meio da rua, ou de investir contra o cinegrafista, à maneira dos bandidos e dos artistas principais (BUARQUE, 2004, p. 7-8).

Caso se considere o seu passado de modelo fotográfico, talvez se pense que Benjamim devesse ter adotado não uma câmera filmadora, mas sim uma máquina fotográfica, para cujo funcionamento e resultados estaria mais bem "adestrado". A opção errônea realça a defasagem entre o seu modo de representação estático e o mundo de filmagens que de repente é forçado a adentrar. Esse Benjamim fantasmático, resto de imagens cristalizadas em fotos, revela ao mesmo tempo um universo já esvaziado e o seu grande estranhamento diante do que se vai configurando como o modo típico dessa nova realidade pela qual é tragado. Paradoxalmente no entanto será guiado por ela para o passado, e justo através da imagem de Ariela, representante bem integrada (ainda que isso signifique um esfacelamento identitário) desse novo universo que para ele apenas se descortina.

Vinda do interior, Ariela se integra a sua "vida nova" de trabalho na metrópole como se se tratasse mesmo de uma nova vida que se inicia. Enfraquecidos os laços e apagados os rastros, ela naturalmente assume suas "funções" de corretora de imóveis e mulher de policial. As atmosferas que a encarceram, de indiferença e superficialidade, nas relações de trabalho, e de violência, no campo afetivo, são sorvidas como ao ar, sem estranhamento, sem resistência, indiferentemente. Se se pode imaginar que exista uma ponta de revolta, é aquela que deságua no interior dela mesma, sentimento a que responde se autoflagelando: 
Olha-se no espelho, agarra dois maços de cabelos, experimenta arrancá-los, atira-se de cabeça contra os azulejos. Cai, rasteja em direção à latrina, enfia dois dedos na goela e vê o jato de sangue que borrifa a louça e se dissolve na água. Expele um segundo jato, mais abundante, acha que vai desmaiar, depois percebe pelo paladar azedo que não era sangue, mas vinho do Porto o que ela vomitou. Enche a boca de dentifrício e gargareja sob a ducha gelada. Lava os cabelos, e o xampu escorrido arde em sua pele, como se ela possuísse vários olhos abertos pelo corpo afora: nos seios, nos flancos, nas nádegas, Ariela ainda sente os dentes de Alyandro a tirar pedaços dela (BUARQUE, 2004, p. 144-145).

Enquanto isso, Benjamim Zambraia vive como que fossilizado, ou suspenso no tempo. Sem vínculos de trabalho ou relações afetivas, o ex-modelo, ainda não propriamente idoso, sobrevive da aposentadoria que um dia preparou para si. "Benjamim pensou no que fizera de bom em dois anos - cinema, chope, cinema, cama, chope, cinema, caldo de carne, cama - e falou 'só?'” (BUARQUE, 2004, p. 101-102). Cada um dos personagens é apanhado de um modo diferente pelo efeito maquínico. Percebe-se inclusive uma divisão dos corpos, em partes ou pelas funções que executam. Ariela, no escritório da empresa corretora, "Isola-se em seu módulo e debruça-se na escrivaninha, sem vontade de olhar para as janelas divisórias. Ariela só conhece pelo interfone a voz das colegas de trabalho, que só conhecem Ariela da cintura para cima" (BUARQUE, 2004, p. 61).

Ela é um bom exemplo da naturalização do artifício, da adesão indiferente ao esquema maquinal: enquanto Benjamim declara ter uma câmera no lugar dos olhos, a jovem corretora carrega um relógio internalizado: "ela tampouco faz caso dos relógios públicos em seu caminho, pois tem noção precisa das horas” (BUARQUE, 2004, p. 13). E não se trata de uma metáfora, já que o tempo de Ariela é realmente medido por esse aparelho interior, e não por outros. Exatamente do mesmo modo como a câmera que há décadas acompanha Benjamim passa a coincidir com o veículo do seu olhar: 
Adolescente, Benjamim adquiriu uma câmera invisível por entender que os colegas mais astutos já possuíam as suas. O equipamento mostrou-se tão providencial quanto um pente de bolso, e a partir daquele dia a vida dele tomou novo rumo. Benjamim passou a usar topete, e nas pendengas em que antes se descabelava, certo de estar com a razão, mantinha agora um sorriso vago e deixava o adversário a gesticular de costas para a câmera (BUARQUE, 2004, p. 7).

A adoção da câmera representa assim o início de sua indiferença crônica. É quando, ainda jovem, começa a abrir mão de quaisquer convicções em prol de uma tranquilidade de superfície, esquema que acaba por se naturalizar na sua rotina:

Com isso ganhou prestígio e beijou na boca muitas garotas, cujos ombros, orelhas e rabos-de-cavalo foram imortalizados em suas películas. O acervo de Benjamim também guarda dublagens de cantor de jazz, saltos de trampolim, proezas no futebol, brigas de rua em que sangrou ou se saiu bem e a sua estréia no sexo com uma senhora de idade (trinta anos, trinta e um, trinta e três), quando ele quase estragou a cena ao olhar para a lente. (...) Hoje ele é um homem amadurecido e usa a indiferença como tática para desencorajar as filmagens (BUARQUE, 2004, p. 7-8).

Não se encontra aí também uma mera figuratividade - ou figuração, para introduzir já o paradigma da atuação. É mais que a ideia comum da câmera filmadora como a possibilidade de afastar-se e assistir a tudo estando de fora, como num filme. Nem é somente o caso de Benjamim ter tomado para si, desde a adolescência, o "modo de olhar" da câmera. Agora, diferentemente do que acontecia no começo, ela se insere na sua vida o tempo todo, sem ser acionada. Adquirida a câmera, ele não mais consegue livrar-se dela. Muda o seu modo de com ela relacionar-se, mas ela permanece, acompanhando seus atos e fazendo-lhe tomadas inusitadas. Antes Benjamim assumia o papel de um diretor que, por vezes, participava do filme; agora sua imagem é acessada sem permissão e ele precisa criar estratégias para esquivar-se das filmagens. Não é mais a máquina que surge como acessório para ele; trata-se antes do contrário. 
Como causa ou efeito desse complexo maquínico, Benjamim é uma narrativa de traçado cinematográfico, para além mesmo das muitas descrições e das "tomadas" feitas pela câmera de Benjamim. Existe ali um mais constante e genérico "entregar-se à 'filmagem", com diferenças de uma geração de personagens para outra: entre os mais antigos incluem-se Benjamim e Aliandro Esgarate, remanescentes de um tempo em que a separação entre ser e representar se fazia clara. $\mathrm{O}$ modo como emprestam suas imagens à filmagem de fato é, a um tempo, consciente e ingênuo, em quase tudo dependente da opinião e do trabalho alheios - daí o tom patético de certas tomadas para comerciais de que participa Benjamim, a monstruosidade da foto da campanha política de Alyandro, estampado nos outdoors com o tronco ligado por montagem aos de homens do povo, e a cena ainda mais deplorável em que se juntam os dois, Benjamim tentando representar um respeitável eleitor de Alyandro:

'Meu nome é Diógenes Halofonte, sou professor e cientista social. Conheço Alyandro Sgaratti e posso afiançar: ele é o companheiro xifópago do cidadão.' No banheiro, diante do espelho e do relógio, Benjamim articula sem tropeços o texto que tanto desconforto lhe causou na semana passada. A mensagem devia durar dez segundos exatos, e o assistente de G. Gâmbolo forçou-o a gravá-la e regravá-la sob protestos da equipe, que estava de jejum. Quando o áudio resultava satisfatório, ele encontrava algum defeito na imagem: Benjamim suava na testa, ou contorcera a boca, ou olhara para o monitor. Nas últimas tentativas, mal Benjamim pronunciava o nome do professor, o assistente gritava 'corta!'. Aquilo o intimidava, quanto mais porque, antes dele, apresentaram-se um figurante de televisão, vestido de enfermeiro, e a copeira do estúdio, fantasiada de si própria. Eram pessoas que nunca haviam falado 'xifópago', mas gravaram mensagens semelhantes na primeira tomada. No final da tarde o assistente dispensou os técnicos e transferiu-se com Benjamim para um gabinete sem ventilação. Encostou-o contra a parede, pediu-lhe que erguesse os braços e sorrisse - o que tampouco foi fácil - e sacou uma dúzia de fotos (BUARQUE, 2004, p. 73-74). 
As mãos ao alto, que simulam a ação do eleitor e a vitória do candidato, indicam também a rendição ou "perda da alma" diante da câmera fotográfica. Ao mesmo tempo, multiplica-se aí o gesto que inicia e finaliza a narrativa, repetindo a cena de fuzilamento provocada (e a outra sofrida) um dia por Benjamim.

Das duas gerações a que nos referimos, a mais jovem é representada pelos estudantes que participam da gincana e por Ariela, para quem o ato de dar-se à observação, numa constante e onipresente filmagem, num Big Brother geral como o de Orwell, já se naturalizou. Vivendo sempre, nas cidades, diante de câmeras - reais ou imaginárias - e principalmente diante da dita câmera interior - o que chamamos aqui de inconsciente panóptico, difícil de caracterizar por mera comparação com aqueles outros esquemas maquínicos - essa geração, de um modo geral, tem como traço aquela inquietante e paradoxal naturalização do artifício. Contudo é necessário perguntar: de que ponto de vista se ol ha ao afirmar-se que os jovens hoje encaram com plena "naturalidade" o fato de se sentirem o tempo todo filmados, sabendo-se que essa "naturalidade" pode ser apenas o efeito de interpretar como "natural" - com base em um novo conceito de "naturalidade" - o que seria, na verdade, uma outra lida com o "artifício"?

Apesar da abstração considerada própria da tentativa de marcar o tempo, Ariela, cujo trabalho depende de hora marcada, dispensa o aparelho e se guia somente pelo relógio que já interiorizou. A prescindibilidade do aparelho real, tanto quanto a imprescindibilidade de ter o tempo medido e plenamente ocupado, são expostas, de modo paradoxal, pela dispensa do aparelho, já que cada um traz dentro de si, como escravo seu que é, o próprio "relógio mental" - no caso de Ariela, sempre dez minutos adiantado. Todos os seus pretendentes lhe presenteiam com um relógio (inclusive Benjamim) e é como se cada um deles quisesse levar para junto dela o seu próprio tempo supondo que fosse possível algo como uma "temporalidade própria". No entanto nenhum dos aparelhos, oferecidos como proposta ou promessa, será utilizado por ela. Ariela nem mesmo usa relógio, 
embora possua uns tantos em casa, guardados numa caixa de charutos no fundo de uma gaveta [...] Mas devem estar parados, e ela tampouco faz caso dos relógios públicos em seu caminho, pois tem noção precisa das horas. É de índole pontual, e em pensamento comparece com rigor aos locais de encontro, onde espera apreensiva por seu corpo, sempre dez minutos atrasado (BUARQUE, 2004, p. 13).

"No segundo almoço Zorza ofereceu a Ariela um relógio com corrente de lápis-lazúli. Não permitiu que ela agradecesse, porque era uma mera lembrancinha; tocou seu braço e, encarando-a, contou quantotiravapormêsnaagênciadeautomóveis"(BUARQUE, 2004,p.41). Adiante é a vez de Benjamim:

Ariela suspende-se na ponta dos pés, inclina-se para a esquerda e roça o mamilo no peito de Benjamim para alcançar o estojo. Desembrulha-o sem lesar o papel, que dobra em quatro e guarda na bolsa de lona. Fala 'obrigada' antes mesmo de abrir o estojo, parecendo adivinhar o seu conteúdo. É um relógio de modelo clássico, semelhante ao que Castana Beatriz usava com o mostrador no lado íntimo do pulso direito (BUARQUE, 2004, p. 106).

O relógio, só muito ultimamente substituído pelo telefone celular, e não completamente, destaca-se ainda hoje como objeto de galanteria. Embora o telefone celular tenha assumido a função primordial daquele, de marcar as horas, uma certa aura simbólica continua a envolver o relógio de pulso, alçando-o à condição de presente desejável - quiçá cada vez mais, paralelamente e devido mesmo, de modo contraditório, ao rareamento do seu uso como acessório utilitário.

Numa época em que cada um dos consumidores, inclusive as crianças, leva consigo um telefone celular, que funciona também como computador e relógio, com as horas acertadas via satélite, o relógio de pulso, que até algum tempo atrás era a mais útil das joias, passa agora a supérfluo e redundante, numa inversão do próprio conceito de joia útil, por si só já paradoxal, o que não deixa de alertar, ainda uma vez, para o fato nem sempre tão óbvio de que, no capitalismo, a produção do supérfluo é que cria a demanda do que, só 
então, se faz necessário. Quando usado, portanto, o relógio de pulso recupera a futilidade da joia. Os signos de status que possuiu um dia são transferidos agora ao telefone celular, a depender, logicamente, de sua qualidade e da marca que traz - ele que, além de emitir e receber chamadas, funciona como computador, com todas as suas atribuições, cartão de crédito, máquina fotográfica e filmadora, afora as inúmeras novidades que lhe devem ter sido agregadas durante a escrita deste texto. 


\section{REFERÊNCIAS}

BARTHES, Roland. A câmara clara: nota sobre a fotografia. Tradução Júlio Castañon Guimarães. Rio de Janeiro: nova Fronteira, 1984.

BAUMAN, Zygmunt. Amor líquido. Tradução Carlos Alberto Medeiros. Rio de Janeiro: Jorge Zahar, 2004.

BAUMAN, Zygmunt. Vidas desperdiçadas. Tradução Carlos Alberto Medeiros. Rio de Janeiro: Jorge Zahar, 2005.

BENJAMIN, Walter. Magia e técnica, arte e política: ensaios sobre literatura e história da cultura. Tradução Sergio Paulo Rouanet. São Paulo: Brasiliense, 1993.

BENJAMIM. Direção: Monique Gardenberg. Produção: Natasha e Dueto filmes em associação com Gullane filmes. Intérpretes: Paulo José; Cléo Pires; Danton Mello; Chico Diaz; Guilherme Leme; Rodolfo Bottino; Ernesto Piccolo. Produtores executivos: Paula Lavigne; Augusto Casé. Direção de fotografia: Marcelo Durst. Roteiro: Jorge Furtado; Glênio Povoas; Monique Garbenberg. Música: Jorge Saldanha. 1 DVD (108 min), color.

BUARQUE, Chico. Benjamim. São Paulo: Companhia das Letras, 2004.

BUARQUE, Chico. Budapeste. São Paulo: Companhia das Letras, 2003.

BUARQUE, Chico. Estorvo. São Paulo: Companhia das Letras, 1991.

CARNE TRÊMULA. Co-produção Espanha-França. Direção: Pedro Almodóvar. Distribuição: Fox Home Entertainment. Elenco: Javier Bardem, Francesca Néri, Liberto Rabal, Ângela Molina, Jose Sancho, Penélope Cruz. Dolby Digital 2.0. color., 98 min. 
CÉSAR, Ligia Vieira. Poesia e política nas canções de Bob Dylan e Chico Buarque. São Paulo: EDUFSC/Estação Liberdade, 1993.

COSTA, Gal. "Negro amor”. Caras e bocas. (Rio de Janeiro: Philips, 1977). CD, Faixa 6.

DERRIDA, Jacques. Papel-máquina. Tradução Evando Nascimento. São Paulo: Estação Liberdade, 2004.

ELIAS, Norbert. Os estabelecidos e os outsiders: sociologia das relações de poder a partir de uma pequena comunidade. Tradução Vera Ribeiro. Rio de Janeiro: Jorge Zahar, 2000.

FOUCAULT, Michel. Vigiar e punir. Tradução Raquel Ramalhete. Petrópolis: Vozes, 1995.

LISPECTOR, Clarice. A hora da estrela. Rio de Janeiro: Francisco Alves, 1990.

NUNES, Benedito. Artigo na Folha de São Paulo, São Paulo, 03 ago. 1991. Disponível em: <http://chicobuarque.uol.com.br/>. Acesso em: 10 jun. 2006.

PAES, José Paulo. Artigo na Folha de São Paulo, São Paulo, 31 dez. 1995. Mais!. Disponível em: $<$ http://chicobuarque.uol.com.br/>. Acesso em: 20 abr. 2007.

SANTIAGO, Silviano. O cosmopolitismo do pobre. Belo Horizonte: UFMG, 2004.

SANTOS, Milton. Técnica, espaço, tempo: globalização e meio técnicocientífico informacional. São Paulo: HUCITEC, 1997.

SIBILIA, Paula. O homem pós-orgânico: corpo, subjetividade e tecnologias digitais. Rio de Janeiro: Relume Dumará, 2002. 



\section{CHICO BUARQUE E O CORAL DE VENTRÍLOQUOS}

Budapeste, livro lançado em 2003 sob o nome de Chico Buarque, inaugura, já na forma como o título e o nome do autor são dispostos na capa, uma série de relações especulares através das quais a questão autoral, entre outras, será trazida à tona ao longo da narrativa. Olhado de fora o livro aberto, nota-se, na contracapa, uma espécie de reflexo das palavras postas na capa. Naquela os nomes da obra e do autor - "Budapeste, Chico Buarque" - aparecem invertidos com relação a sua posição na capa, e ali se encontra: Budapest, Zsoze Kósta (inscrição fonética de como o ghost writer brasileiro José Costa percebe a pronúncia de seu nome na Hungria).

o espectro reflexivo do título do romance e do nome do autor anuncia o profuso jogo identitário que se inicia. A partir do estranhamento causado por um livro em cuja capa figuram dois títulos e dois nomes de autor, uma série de anagramas e paradoxos formará um jogo no qual entram em questão enigmas especulares e outros elementos reversíveis em torno da ideia de autoria e dos conceitos que a envolvem, como: valor, autoridade, propriedade, reconhecimento, ciúme, identidade, paternidade e vaidade intelectual. Assim, dividindo de maneira radical o status autoral com um de seus personagens, elevando-o, no arranjo dado à publicação, à condição de coautoria ficcional, "Chico Buarque" sobressai, no entanto, no dorso do livro, preservado com todas as letras, como o nome daquele que responde juridicamente pela publicação. 
De início importa lembrar que a relação do escritor-fantasma (ghost writer) com "seus" textos, com os assinantes destes, com o público leitor e com o mercado em geral não é simplificada pela ausência de um nome que identifique aquele que escreve. Pelo contrário, esse writer é posto numa situação em que experimenta lugares e funções indefiníveis entre o público e o privado, entre a autoria e o anonimato. É vivido a fundo por José Costa, o que chamaremos de paradoxo da anônima autoria, do que escreve, mas não pode - ou não quer - assinar. Imperam então razões a priori inusitadas, como a que solicita "direitos de privacidade": se se fala em direitos autorais, por que não se aceita a existência do direito de escrever um texto e não o ligar ao próprio nome?

A questão é mais complexa do que parece a princípio, porque o sistema da escrita, sobretudo como se desenvolve hoje, mediante a farta recorrência ao pastiche, ao plágio, à citação e à paródia, torna ralas as barreiras de determinação autoral. A ficção convida assim a um sem fim de simulacros e armadilhas em que o nome do autor é apenas um dos elementos, dificultando também uma clara delimitação entre real e ficcional, como se fez até bem pouco tempo sem grandes problemas. Como determinar então os limites da pessoalidade autoral e das normas éticas que regulem as possibilidades de uso e de apropriação dos textos? E, ainda: como algumas editoras conseguem, na lei, a fenda que lhes permite empregar normalmente, sob a denominação de redatores, pessoas que escrevem textos que serão comercializados sob os nomes de escritores conhecidos, que lhes aplicam, assim, a sua griffe ${ }^{6}$ ?

6 Apenas para permanecer, neste ponto, no terreno da ficção, lembramos o livro do escritor espanhol José Luis Saorín - A curiosa história do editor partido ao meio na era dos robôs escritores (no original Fusiones, confusiones, infusiones). Em sua trama o editor Ramón Ferrero, verdadeiro autor secreto dos romances que ele mesmo publica sob o pseudônimo de Nomar Wallace (cujo prenome é palíndromo de Ramón), trabalha na área de literatura de uma grande empresa, o que facilita a publicação e a divulgação de seus romances. Em meio às peripécias que envolvem a troca de identidades entre autor e editor, Ramon descobre a secreta trama criminosa que envolve a morte (literal) do autor Jaime Zerep (inversão de Perez, sobrenome de Saorín não assumido no nome artístico). Aos poucos desvenda-se para ele um panorama macabro: para livrar-se dos custos com direitos autorais, os editores-chefes da VMG encomendam a morte dos 


\title{
A relativa singularidade que um nome de autor estabelece demarca um território discursivo sobre o qual esse nome bruxuleia, criando uma ilusão de familiaridade para quem ali penetra e seccionando aquele discurso dos demais. Com Foucault, pode-se afirmar que:
}

\begin{abstract}
(...) numa civilização como a nossa, uma certa quantidade de discursos são providos da função 'autor', ao passo que outros são dela desprovidos. Uma carta privada pode bem ter um signatário, mas não tem autor; um contrato pode bem ter um fiador, mas não um autor. Um texto anônimo que se lê numa parede da rua terá um redactor, mas não um autor (FOUCAULT, 1992, p. 46).
\end{abstract}

autores. Num encontro de editores e escritores em Tenerife, que lembra o estranho "encontro anual de autores anônimos" de Budapeste, em meio a palestras sobre a importância do peso do livro no seu valor de mercado ou a influência do título no marketing de uma obra, Ramón/ Nomar vive toda sorte de dúvidas e auto-questionamentos éticos acerca de sua (dupla) vida e trabalho, trapaceando entre a identidade editorial e um disfarce que inventara para o autor de best sellers. Em meio a novidades como a inserção de publicidade no interior dos livros (tanto nas orelhas como na trama dos romances), a editora espanhola de Ramón Ferrero desenvolve um sistema de escravagismo literário, recrutando jovens sul-americanos sem documento, que vivem clandestinamente na Europa e dominam o idioma espanhol, muitas vezes detentores de títulos de doutor em literatura, para desenvolver as narrativas cujo tema é sugerido por autores de renome que, tendo seu estilo imitado por inúmeros "escravos literários" de uma só vez, rende à editora um best seller em questão de dias, sendo que o livro recebe na capa o nome do escritor já conhecido. Disfarçados nos famosos EAC, programas de Escrita Assistida por Computador, os presidentes dos centros de escravidão literária pretendem cooptar Nomar para ser mais um de seus "senhores". Ao aproximar-se inconformado da que seria designada a sua primeira escrava naquele submundo literário, ele descobre também a existência do EAO, um programa para produzir argumentos ficcionais, o que decreta a completa dispensabilidade do escritor, mesmo como mero fornecedor de argumentos. A situação atinge limites tão absurdos que adiante, sem revelar suas descobertas acerca do EAC e do EAO, Ramón Ferrero participa de uma reunião na editora e, frente as afirmações do palestrante de que "ninguém mais compra um livro ou um filme como unidade" e de que "o preço está atrelado ao tempo ou às páginas que você compra” (SAORÍN, 2005, p. 180), o próprio Ferrero se ergue e lança suas pérolas: “- Os frangos também são vendidos em pedaços! (...) - Quem sabe a gente poderia vender os capítulos avulsos, ou as capas, ou as palavras soltas.” (...) “ - A gente podia colocar uma balança nas livrarias e cada um pesava seu livro. (...) - Cada autor teria um preço por quilo de livro e a gente poderia oferecer várias opções de tipo de letras. Assim, quem quisesse economizar compraria livros com a letra menor, que pesariam menos. (...) - A gente poderia fazer leilões pela Internet dos quilos de livros por autor e chegar a preços lógicos. Como se fosse uma bolsa de cada autor, e os leitores compartilhariam ações. Cada livro novo seria uma ampliação de capital e dependendo da oferta e da demanda teríamos um preço/dia para cada quilo de livro" (SAORÍN, 2005, p. 182). Suas ideias foram acolhidas com notoriedade. 
A função autoral não se forma, é claro, espontaneamente, imputando-se um discurso a um indivíduo. Existe atuando aí, na "construção" de um autor, uma operação complexa. O que se designa no indivíduo como sendo o "autor" é a projeção do tratamento que damos ao texto. De acordo com Foucault, a crítica literária autenticou seus autores como a tradição cristã autenticou seus textos: para encontrar o autor na obra. Assim como se provava o valor de um texto através da santidade do autor, a crítica literária moderna explicava a obra através da vida de quem a produziu.

Também não há universalidade e constância na função autor. Houve épocas, por exemplo, em que o anonimato não era uma questão a ser desvendada, porém ainda na Idade Média surge a necessidade de que se nomeiem os textos, para que tenham sua validade reconhecida. Já nos séculos XVII e XVIII os textos científicos começam a ser aceitos por si, no anonimato de uma verdade estabelecida e constantemente demonstrável, por pertencerem a um grupo sistematizado, o que passou a importar prioritariamente para a sua eventual filiação a determinado nome de autor. Arrefece desse modo, primeiramente, a imprescindibilidade da função autoral para as ciências em geral.

Os textos literários contudo passam a necessitar da função autoral, entre outras razões, para efeito de valoração. As reflexões de Michel Foucault destacaram o papel preponderante do autor nas obras literárias. Atualmente porém é preciso notar que essa preponderância tende ao paradoxo, num jogo em que esconder é expor ainda mais, pelo fato de que o personagem autor é muitas vezes, agora, mais uma entre as instâncias que compõem o jogo ficcional, participando da trama e levando assim, para dentro dela, o nome de autor. Essas transformações se aceleram com a existência de textos como Budapeste, que trazem à tona questões cruciais ao pensamento do nosso tempo sobre a função autoral e seus desdobramentos.

A trajetória de José Costa pela narrativa representa uma certa alegoria dessa "história da autoria", iniciando pelo momento em que simplesmente produz, sem se preocupar com o destino de seu 
nome. É a época em que, ainda no curso de Letras, pobre e morador do subúrbio, troca redações por caronas com o colega Álvaro, que se tornará, anos depois, seu "sócio-empregador". Futuramente, já instalado na "fábrica de textos", desempenhando o trabalho altamente comercializável que declara ser um "exercício de estilo", Costa saboreia profundamente o anonimato. Interessa-lhe sobretudo ver os "seus" textos seguirem, não importa sob o nome de quem. Confessa então não se sentir traído por entregá-los anonimamente; ao contrário, é como se estivesse "tendo um caso com mulher alheia" (BUARQUE, 2003, p. 18), usufruindo secretamente o prazer do texto pelo qual não precisa responder; em última instância, livre até mesmo de certas sanções legais que fundamentam, modernamente, a responsabilidade autoral. Posteriormente, adere a uma ideia difusa de "categoria". É quando procura escrever apenas para a "categoria" dos anônimos. Adiante começa a fruir enormemente o prazer sarcástico de ter seus textos publicados sob os nomes de "grandes escritores". Por fim, vive a situação irônica de ver lançado sob seu nome um texto que não escreveu, deambulando nesse jogo de papéis reversíveis entre identidade e anonimato.

Os acontecimentos descrevem uma trajetória em que, mesmo trabalhando no anonimato, José Costa se conduz de ghost writer de anônimos a ghost writer de renomados. Ou seja, de duplamente desconhecido a um meio sem nome. A desauratização do objeto de arte que acompanha esse processo não tem como consequência uma simplificação da função autoral. Ela continua sofrendo transformações, a se questionar, mas nenhuma que esmaeça a necessidade do próprio questionamento.

O fato de o escritor José Costa não ter sequer seus textos assinados, não respondendo pelos pensamentos que veiculam, nem podendo usufruir publicamente dos comentários que se teçam acerca deles, põe uma lupa sobre a ilusão de real, ou a ilusão de correspondência simples, que envolve, na leitura, a obra e o nome do autor. Aliás, quando aumenta a profusão de textos escritos por Costa, por exemplo, principia ele próprio a tecer sua elogiosa exegese, sob os 
nomes de críticos literários conhecidos; trata-se de uma atitude que - percebemos depois, nos relatos que faz do congresso anual - se torna cada vez mais comum entre aqueles muitos escritores anônimos. Roland Barthes já chamara à atenção para o fato de que a crise da escrita é a crise da crítica. Na Hungria, ao receber homenagem, dessa vez pela publicação de um livro que não escreveu, o ghost writer José Costa, posto então em condição de personagem conduzido pela narrativa de outro, chega ao ponto que se poderia considerar um extremo fantástico da permuta de vozes: "Fui recebido no Parlamento, jantei no Palácio do Arcebispo, na Universidade de Pécs me concederam um título de doutor, que agradeci com um discurso empolado, surgido em meu bolso não sei como" (BUARQUE, 2003, p. 170-171).

A própria existência de um "encontro anual de autores anônimos", nos moldes de quaisquer outros encontros de escritores, é prova da impossibilidade de se negar a concepção de autoria e o sentimento de propriedade intelectual, pois, se por um lado parece absurda a existência de um congresso de ghost writers para discutir questões de ética e direitos autorais, por outro ela é perfeitamente cabível, já que a defesa da propriedade intelectual é, ao final, garantia do valor, que interessa tanto àqueles que assinam as obras quanto aos escritores que lhes estão por detrás, produzindo, já que cuidam, ambos, de um único produto.

As questões arroladas em Budapeste obrigam também a repensar algumas categorias que a crítica literária está acostumada a manipular com relativa simplicidade. Ao iniciar a escrita do primeiro romance que lhe é encomendado e que se basearia nos relatos feitos pelo "cliente" diante do gravador, José Costa "encarna" o personagem e a narrativa passa, de forma quase imperceptível, de uma terceira a uma primeira pessoa, por meio de recursos que dificultam identificar até onde fala o narrador de Budapeste e onde principia a fala do narrador de $O$ Ginógrafo, este livro dentro do outro. E também o contrário, ao fim do relato, porque nesse ponto da escrita as duas vozes não se seccionam, antes se interpenetram, em dueto: 
De qualquer modo naquele instante fechei o jogo, arregacei as mangas, pousei os dedos no teclado, zarpei de Hamburgo, adentrei a baía de Guanabara e preferi nem ouvir as fitas do alemão. Eu era um jovem louro e saudável quando adentrei a baía de Guanabara, errei pelas ruas do Rio de Janeiro e conheci Teresa. Ao ouvir cantar Teresa, caí de amores pelo seu idioma, e após três meses embatucado, senti que tinha a história do alemão na ponta dos dedos. A escrita me saía espontânea, num ritmo que não era o meu, e foi na batata da perna de Teresa que escrevi as primeiras palavras na língua nativa (BUARQUE, 2003, p. 38-39, grifo meu)7.

Tudo isso parece recolocar a questão foucaultiana do sujeito originário:

Como, segundo que condições e sob que formas, algo como um sujeito pode aparecer na ordem dos discursos? Que lugar pode o sujeito ocupar em cada tipo de discurso, que funções pode exercer e obedecendo a que regras? Em suma, trata-se de retirar ao sujeito (ou ao seu substituto) o papel de fundamento originário e de o analisar como uma função variável e complexa do discurso (FOUCAULT, 1992, p. 69-70).

Segundo Foucault, autor seria uma das especificações possíveis da função sujeito. Possível, não necessária, conclui o filósofo francês ao imaginar uma sociedade em que a ideia de autor não existisse, onde circulassem apenas os discursos, não importando quem falasse ${ }^{8}$. Cada parte deste estudo quer lembrar que o nome do autor

\footnotetext{
7 A expressão "fechei o jogo" refere-se ao hábito que tem José Costa de jogar "paciência" no computador enquanto não consegue produzir. No momento destacado acima, o ghost-writer, surpreendido pela entrada súbita de seu sócio no escritório, sintomaticamente encerra um jogo para iniciar um outro, o da escrita.

8 É curioso que raciocínios acerca da função autoral, como os de Barthes e Foucault, geradores de fortes polêmicas (principiando pela que se segue à fala de Foucault no momento da apresentação de suas ideias no Collège de France) gerem tantos outros discursos, alguns deles paradoxais no ponto mesmo em que tocam o tema principal dos dois ensaios. A título de exemplo pode-se conferir a colagem que simula um diálogo entre os dois pensadores, divulgada em site brasileiro e feita a partir dos discursos de Barthes e Foucault sobre a função autoral. $\mathrm{O}$ autor do arranjo não é nomeado, parecendo alegar implicitamente, como justificativa para o seu anonimato, os argumentos dos textos plagiados:
} 


\section{não conduz, de modo simples, um certo discurso diretamente a um indivíduo real e exterior que o tenha produzido. Esta "função"}

serve para caracterizar um certo modo de ser do discurso: para um discurso, ter um nome de autor, o fato de se poder dizer 'isto foi escrito por fulano' ou 'tal indivíduo é o autor', indica que esse discurso não é um discurso quotidiano, indiferente, um discurso flutuante e passageiro, imediatamente consumível, mas que se trata de um discurso que deve ser recebido de certa maneira e que deve, numa determinada cultura, receber um certo estatuto (FOUCAULT, 1992, p. 45).

O nome do autor estabelece um recorte para o interior do texto, ao qual tenta impor uma certa homogeneidade, ainda que hoje - especialmente em escritas como a de Budapeste - essa homogeneidade só se

Michel: - O que é um autor? o que é uma obra?

Roland: - $O$ autor reina ainda nos manuais de história literária.

Michel: - A ausência é o lugar primeiro do discurso.

Roland: - É a linguagem que fala, não o autor.

Michel: - Seria tão falso procurar o autor no escritor real como no locutor fictício.

Roland:- Dar um autor a um texto é impor a esse texto um mecanismo de segurança.

Michel: - O nome de autor serve para caracterizar um certo modo de ser do discurso.

Roland: - O texto é um tecido de citações, saídas dos mil focos da cultura.

Michel: - Que importa quem fala.

o "diálogo" intitula-se "Conversa Des-autor-izada" e abrange o duplo sentido da expressão: não apresenta a "identidade" daquele que escolheu os trechos e compôs a colagem, nem credita as falas a seus autores - Michel Foucault e Roland Barthes. Também não se utilizam aspas. Embora os trechos dos ensaios de ambos os pensadores sejam facilmente reconhecíveis por interessados no tema da autoria, também é possível que, de um modo geral, e pelo modo como são "des-autorizados" no site, se os leia como trechos de uma conversa "qualquer" entre dois internautas conhecedores de parte da história da crítica literária. Os nomes do semiólogo e do filósofo franceses aparecem ali como meros nomes próprios - Roland e Michel -, sem os sobrenomes que os identificariam indubitavelmente, o que joga ainda uma vez - contrariando-a - com a ideia de que um nome de autor não se substitui simplesmente por um pronome como "ele" (FOUCAULT, 1992, p. 44), ou de que ao nome do autor não se subtrai o sobrenome etc. A "conversa" continua ali, duplamente "desautorizada", como se, plagiando o próprio Michel Foucault em seu discurso, "não importa[sse] quem fala". Na página seguinte à do diálogo simulado, encontramos uma lista de referências, que parece servir antes ao site como um todo do que a essa parte, especificamente. (Disponível em <http://www.conversadesautorizada.com.br/> em 13 de agosto de 2006. Atualmente o site não se encontra mais acessível). 
dê, paradoxalmente, por meio do reconhecimento de quantas diferenças aquele "autor" é capaz de criar e pôr sob seu próprio nome.

Qual não é, por outro lado, a problemática do ghost writer José Costa, cuja escrita não conta com o apoio de seu nome, e cujo nome, ao final da narrativa de Chico Buarque, aparece sobreposto a uma escrita "autobiográfica" que não é a sua (ao menos até que se converta em leitor dela e, ao mesmo tempo em que lê, reconheça-se como personagem da história lida, num entrelaçar das funções de leitura e escrita)? Melhor dizendo: Qual será a situação se ele não pode pôr sob seu completo domínio, sob o domínio do seu nome, a sua produção ${ }^{9}$ ?

Sentimentos de poder e de posse fazem parte da relação que se costuma estabelecer entre um autor e os seus textos. Uma relação por vezes tão intrincada que leva, quase que automaticamente, à comparação com a relação entre um pai (ou mãe) e seus filhos. Seja porque a ideia central em ambos os casos é a de pertencimento, e portanto do possível perpasse de uma certa "herança" - apomos nosso nome ao texto como o damos aos filhos -, seja pela crença em que o autor deixa na escrita as marcas do seu mais íntimo, algo da sua essência ou da sua semente - como se crê, com base em ramificações da medicina, que também no filho segue parte dos genes e da psique dos pais. Diz-se ainda que alguém "pariu" um texto, metáfora que se desdobra em outras do mesmo teor. Desse modo, a ideia de autoria se liga à de paternidade e, embora cotidianamente não se fale

\footnotetext{
9 Numa sociedade em que escritores procuram desesperadamente por editoras para seus livros, é cômico imaginar que, quando José Costa estava ainda no Brasil, a editora húngara de "seu" livro quase não o encontra, em parte devido a quão comum é seu nome, entre milhares de José Costa espalhados pela lista telefônica, e em parte porque ele não tem morada fixa e pula de hotel em hotel, sem ter como pagar as diárias. Nesse ponto a narrativa parece interrogar: Quando não se tem um teto próprio, para que serve o nome próprio? Afinal, é preciso considerar a situação sócio-econômica de Costa para entender sua "inclinação" ao anonimato e - diga-se de passagem - a de tantos outros "escritores anônimos". Não é por uma opção pura e simples que ele segue produzindo anonimamente. É que com seu trabalho, simplesmente, não terá acesso às editoras, a não ser através dos nomes de pessoas conhecidas, de escritores famosos ou de sujeitos endinheirados, como é o caso do empresário alemão que lhe encomenda sua primeira biografia (o possessivo adquire, nesse caso, uma curiosa ambivalência, referindo-se ao mesmo tempo ao comprador do texto e àquele que o escreve).
} 
em autoria de filhos, fala-se, de modo figurado, em paternidade de textos, em parir teses etc ${ }^{10}$.

No ensaio intitulado Salvo o nome, Derrida sintetiza "o que quer dizer herdeiro. Tanto dar o nome quanto recebê-lo" (DERRIDA, 1995b, p. 73). A questão da nomeação é um dos elos que ligam autoria e paternidade. A escrita, abandonada a si própria, feito órfã - diferentemente do lógos vivo, de certo modo "sustentado" pelo pai -, é uma espécie de morto vivo que ameaça, com sua meia-existência, a existência plena do pai-autor. Enquanto a fala é plenamente assumida, mantida de pé pela voz viva e presente do pai, a escrita segue para além dele e negando-o, na sua rigidez cadavérica.

10 No quase-romance (denominação do autor) de Carlos Heitor Cony intitulado Quase memória, o narrador, chamado Carlos Heitor Cony, explica (no prólogo, denominado "Teoria geral do quase") que "os personagens reais e irreais se misturam" e que "uns e outros são fictícios" (CONY, 1995, p. 7). Cony recebe, do porteiro do hotel onde costuma almoçar, um embrulho amarrado com barbante e a ele endereçado. Reconhece no pacote, de imediato, a tinta, a caligrafia e, principalmente, o caprichoso trabalho de amarração do pai, seu homônimo e jornalista como ele, morto dez anos antes. Tem início aí uma viagem pelo passado - quase memória. O narrador leva o embrulho para o escritório e aos poucos sente retornar o perfume do pai, entre outros perfumes. Em vez de simplesmente abrir o embrulho, principia a rememorar lances do convívio entre eles, nem sempre harmonioso, desde sua infância até à vida adulta e à morte do velho jornalista. O leitor, que anseia pelo desvendamento do mistério do pacote (o quê, afinal, haveria dentro dele?), chega ao fim da narrativa sem conhecer-lhe o conteúdo. Melhor: ele o conhece pelo desenrolar da própria narrativa: o pacote contém as quase memórias imaginárias, inventadas e/ou vividas pelo narrador, porque é ele, afinal, que as detona. 0 volume que por fim se entrega ao leitor é o próprio quase-romance de Cony. Não importa se a caligrafia na encomenda é mesmo do pai, nem o que estaria (se estaria) embrulhado ali, porque o objeto, o volume (o narrador o chama sua "madeleine") desencadeia o processo mnemônico que resulta no texto que o leitor ora tem em mãos. Por isso cada capítulo se inicia por uma tentativa de abordagem (no duplo sentido) do pacote, cada investida deflagrando uma lembrança e a narração dela. E a questão da escrita (a caligrafia do pai, a profissão de jornalista de ambos, o embrulho anônimo, a tinta e os borrões), o desprezo de Cony pai pela literatura escrita, em prol da oralidade, a emocionante pedagogia criada por ele para ensinar ao filho conteúdos que este não conhecera pela escola, já que não a frequentara, enfim, toda uma história individual da escrita é registrada, unindo escritura e paternidade. A história aborda ainda a passagem de um modo de escrita "artesanal" para a era da máquina de escrever, mudança que deixou sem emprego muitos profissionais experientes, entre eles o pai do narrador, que não sabiam datilografar e aos quais foi difícil (quando não impossível) a adequação ao aprendizado da nova técnica. Essa quase memória é a história de uma herança de escrita, que acaba sendo um belo encaminhamento - num registro de rara leveza - das relações impreterivelmente conflituosas entre pai e filho. 
Durante o tempo da narrativa, José Costa empreende nada menos que seis viagens para fora do Brasil, algumas delas para participar do encontro anual de autores anônimos. Ao fim de cada uma dessas idas e vindas, surpreende-se (e ao leitor) com as transformações sofridas por seu corpo e pelos lugares a que regressa. Nessas ocasiões, a linearidade temporal é totalmente abolida. Um exemplo: ele passa algum tempo (que não parece ser muito) na Hungria, e, quando retorna, encontra, numa rua do Rio de Janeiro, seu filho já adulto ${ }^{11}$. Joaquinzinho (que tivera, na infância, a fala retardada, segundo a babá por ter se olhado ao espelho quando bebê) é agora skinhead e, sem reconhecer o pai, confunde-o com um “veado" (BUARQUE, 2003, p. 155), persegue-o e tenta matá-lo. É o filho bastardo e parricida, assemelhando-se nisso à escritura, abandonada à própria sorte mas carregando consigo, ainda assim, a marca e o nome do pai:

Era um palmo mais alto que eu, meus olhos batiam no seu peito, e por instantes imaginei que poderia decifrar os hieróglifos ali tatuados. Depois olhei os olhos com que me fitava, e eram olhos femininos, muito negros, eu conhecia aqueles olhos, Joaquinzinho. Sim, era meu filho, e por pouco não pronunciei seu nome; se eu lhe sorrisse e abrisse os braços, se lhe desse um abraço paternal, talvez ele não entendesse. Ou talvez soubesse desde o início que eu era seu pai, e por isso me olhava daquele jeito, por isso me encurralava no muro. E fechou o punho, armou o golpe, acho que ia me acertar o fígado, quando umas vozes surgiram ao meu lado (BUARQUE, 2003, p. 156-157).

Note-se como Costa, há tanto tempo afastado de seu rebento e sem qualquer vínculo com ele no presente, é incapaz de decifrá-lo,

110 recurso utilizado para justificar tão bruscas quebras temporais é uma espécie de phármakon, embotador de uma certa sensibilidade e aguçador de outra. José Costa confessa ter sempre misturado, no avião, barbitúricos e vinho, partícipes no abalo da temporalidade, que é tão magicamente quebrada na narrativa, mas que tem contudo uma explicação científica na existência dos fusos horários. Ora, se existe algo como o fuso horário, prova da relatividade do tempo e de que não se pode pretender simplesmente reduzi-lo a uma medida absoluta e indiferente à noção de espaço, então por que não pode também a ficção, com liberdade, perverter as regras de verossimilhança comumente impostas a ela? E mais: do mesmo modo que se desdobra na narrativa o tempo, desdobra-se em diferentes vozes aquele fio discursivo que estamos acostumados a acompanhar como se viesse sempre de uma mesma persona, una e indivisível. 
ou aos "hieróglifos" que traz tatuados no peito, como a uma escrita há muito deixada para trás ou entregue ao domínio público. Como os tantos textos já esquecidos, que escrevera e publicara no Brasil sob os nomes de outrem.

Já em se tratando de Pisti, filho de Kriska, a professora com quem se envolve na Hungria, Zsoze Kósta aceita bem mais esse filho que não é seu (assim como é obrigado a assumir, lá, um livro que não escreveu).

Em outra ocasião, comemora no Brasil um Natal e um Carnaval e, quando retorna a Budapeste, Kriska já tem um outro filho, que o ghost não sabe se é seu, acontecimento que se apresenta diante de seus olhos como um delírio ou um filme rodando em flash back:

Enfim me aprumei, fixei o olhar à minha frente, minhas pupilas estavam dilatadas, e o rosto semi-encoberto de Kriska me parecia redondo, achei que ela tinha engordado muito. E quando compreendi que ela estava grávida, comecei a tremer todo, deu um trejeito nos meus lábios, paralisei. Meio vesgo e de boca torta fiquei congelado, porque Kriska deu uma pausa no vídeo para acudir a criança, que desatava a chorar. Quando não estava amamentando, ela gostava de mostrar suas filmagens, as imagens vacilantes, o zoom irrequieto; tinha a minha cena no aeroporto, tinha a criança no berçário, o parto era para eu ter filmado, mas na hora me senti mal e saí da sala (BUARQUE, 2003, p. 168).

Ao "fugir" do Brasil para outro país, José Costa se desvia do lugar de pai e nega ao filho o aprendizado da palavra (por trauma ou falta de estímulo, a criança não aprende sua própria língua; simultaneamente, seu pai aprende, de um modo quase mágico, a "única língua do mundo que, segundo as más línguas, o diabo respeita” (BUARQUE, 2003, p. 6)), passando a falar fluentemente o magiar e, inclusive, a escrever, para falantes natos do húngaro, textos em verso e em prosa, decaindo então à condição de escritor fantasma não remunerado. José Costa apresenta-se, assim, como um duplo fantasma: pela escrita que não assume, como ghost, e pela paternidade que, ausentando-se, renega.

o jogo fatal que liga autor e obra não é, jamais, uma partida 
de lances unilaterais. Caso se consumasse o assassinato do pai, ameaçado por Joaquinzinho no encontro no beco carioca (também ele não "assumido", já que se trata de matar um "desconhecido"), o filho destruiria o fantasma paterno que retorna de suas viagens e aventuras: "[...] desse modo, ele [o Pai] se desvia do lugar de Pai, sempre morto, como se sabe; pois só o filho tem fantasmas, só o filho está vivo" (BARTHES, 1989, p. 45). Rejeitar o filho (assim como não assumir a escrita) livra de obrigações, mas diminui, por outro lado, o espectro do poder paterno, assim como o do direito autoral, patenteadores, respectivamente, de autoridade e de autoria.

Assim como alguns encomendam a José Costa um texto, assinando um trabalho que não realizaram, ele próprio, num certo momento, tem de assumir tarefas feitas por outrem. A princípio quando não consegue suprir a demanda na "fábrica de textos" e depois quando lhe é imputada "espontaneamente" sua autobiografia, ato visto como uma forma de vingança do enigmático Sr.... (assim mesmo anônimo), verdadeiro pai de Pisti.

A denominação Sr.... (com quatro pontos e não com três, como numa reticência), dada ao personagem que lança o livro sob o nome e sobre a vida de Kósta sem sua autorização, remete àquele "senhor" referido por Roland Barthes em Aula:

As forças de liberdade que residem na literatura não dependem da pessoa civil, do engajamento político do escritor que, afinal, é apenas um 'senhor' entre outros, nem mesmo do conteúdo doutrinal de sua obra, mas do trabalho de deslocamento que ele exerce sobre a língua (BARTHES, 1989, p. 17).

No caso de que tratamos, o jogo tem sua força de questionamento, ameaçando, como veremos, arrastar a dúvida acerca da autoria até a figura externa ao texto, que é o "senhor" Francisco Buarque de Hollanda, com endereço e número de identidade.

O processo no qual está envolvido o escritor anônimo não é simples e a sua posição acarreta o sentimento ambíguo de ao mesmo 
tempo fruir a não identificação e, igualmente, lamentá-la. Quando o trabalho de Costa começa a ser copiado pelo ghost writer contratado por seu sócio para imitar-lhe o "estilo" é que o paradoxo se mostra de forma inexorável. Ainda que para o público o seu nome não exista, Costa se sente lesado no modo pessoal de escrever e, desde que nota que pode ser imitado por outro "redator", emerge a pergunta sobre que importância têm os traços que ele acredita caracterizarem e distinguirem o seu trabalho. Do nosso lado, perguntamo-nos se ainda se pode recorrer à ideia de algo como o "estilo" para representar a marca inconfundível e ser prova da autenticidade de um determinado discurso, de um dado autor, se é ainda em idiossincrasias como essa que se baseia, hoje, a noção de autoria.

Como dissemos, a partir da capa uma dimensão especular guia todo o texto: José Costa (cujo sobrenome significa aquilo que fica por detrás, acepção que se estende, nesse caso, para o que trabalha "às escondidas") é sempre, irremediavelmente, um "autor-fantasma" quando escreve para que outros assinem -, ou um "fantasma-autor" - quando "assume" o que outros escreveram. Está preso numa rede (a da escrita) que o enreda sempre incompleto, pela metade, sempre quase, vindo revelar, de modo destorcido, a impossibilidade da, um dia sonhada, plenitude autoral e, por extensão, identitária - ou mesmo ontológica. A descrição do encontro com o primeiro ghost writer contratado por Álvaro para assumir o seu posto ilustra bem o "estar por detrás" que caracteriza a função de ambos, o ghost writer e o ghost writer do ghost writer. No caso, um duplo "estar por detrás": "Para não me aborrecer, decidi ignorar os textos do rapaz, e me sentava de costas para as costas dele, porque é impossível criar com um estranho fitando a nossa cara" (BUARQUE, 2003, p. 23, grifos meus). Além de que José Costa (Zsoze Kósta) é o nome que aparece nas costas (ou quarta capa) do livro Budapeste, constituindo uma espécie de duplo ou reverso do nome de autor "Chico Buarque", algo cujas repercussões serão explicitadas adiante.

Numa primeira instância e escrevendo, inclusive, na língua materna, José Costa vive com seus textos algo parecido com a relação 
de um pai que não assume completamente os filhos, conforme se constatou. Ele os produz e passa a outros para que lhes deem seus nomes. Sua relação com Joaquim, filho seu com Vanda, tem esse mesmo ingrediente de uma assunção incompleta. Desse modo, pelo caminho que traça na narrativa, José Costa abala a visão tradicional do escritor como alguém que viceja numa relação de interioridade e anterioridade para com o texto que lhe sucederia como um apêndice, um filho ou um rebento continuador, assemelhando-se antes ao scriptor de Roland Barthes ${ }^{12}$. A sua dupla existência Brasil-Hungria põe em causa a relação de obrigatoriedade que uma completa identificação acarretaria. Por isso, é possível a José "dar as costas", de uma só vez, às mulheres, à escrita, aos idiomas, aos filhos e aos livros, sem ter de assumir inteiramente nenhum deles. Até certo ponto não importa se os textos que escreve não são assinados por ele, porque a vaidade da autoria, culturalmente arraigada, prescinde, quase paradoxalmente, da evidência pública, correndo mesmo o risco de suplantar o seu alcance costumeiro, se vivida secreta e solitariamente, como consta dos relatos do ghost:

E novos artigos me eram solicitados, e publicados nos jornais com chamada de capa, e elogiados por leitores no dia seguinte, e eu agüentava firme. Com isso a vaidade em mim se acumulava, me tornava forte e bonito, e me levava a brigar com a telefonista e a

12 Para o semioticista, o scriptor moderno é lançado no jogo multi-identitário por recobrir a instância que se dá na própria escrita, sendo-a. Barthes destaca na escrita moderna o seu aspecto performativo - apanhando o termo emprestado à linguística, embora reconheça que essas distinções disciplinares se tornam obsoletas - como uma forma pouco usual, dada na primeira pessoa e no presente, já que o scriptor não persegue com sua mão um pensamento que o precede, mas sim escreve e vive o texto, a sua escrita, no momento mesmo em que ela acontece: "O Autor, quando se acredita nele, é sempre concebido como o passado do seu próprio livro: o livro e o autor colocam-se a si próprios numa mesma linha, distribuída como um antes e um depois: supõe-se que o Autor alimenta o livro, quer dizer que existe antes dele, pensa, sofre, vive com ele; tem com ele a mesma relação de antecedência que um pai mantém com um filho. Exactamente ao contrário, o scriptor moderno nasce ao mesmo tempo que o seu texto; não está de modo algum provido de um ser que precederia ou excederia a sua escrita, não é de modo algum o sujeito de que o seu livro seria o predicado; não existe outro tempo para além do da enunciação, e todo o texto é escrito eternamente aqui e agora" (BARTHES, 1988, p. 51). 
chamar o office boy de burro, e me arruinava o casamento, porque eu chegava em casa e já gritava com a Vanda, e ela me olhava arregalada, não conhecia os motivos de eu estar assim tão vaidoso (BUARQUE, 2003, p. 18).

Seu comportamento acrescenta um toque cômico a uma existência que tem sua parcela de trágico, e sua reação, similar à de um escritor cioso do reconhecimento público, expõe mais um dos sentimentos que envolvem a questão autoral. o orgulho tácito, que confessa apenas a posteriori, na narrativa, mostra que a profunda importância dada à autoria, nas redes de poder que emaranham nome de autor e obra, continua presente mesmo nos textos de falsa autoria. Os sentimentos geralmente inconfessos que adviriam de ver o próprio nome publicado e de colher comentários acerca dos escritos tornados públicos são, nesse caso, dobrados: o ghost writer se envaidece pela qualidade reconhecida de seus textos - que, de certo modo, a própria comerciabilidade prova - e também por poder usufruir disso discretamente, no anonimato. Não é que o orgulho intelectual advindo da assunção à condição de autor dispense, paradoxalmente, o reconhecimento público. O que ocorre é que José Costa - como de resto todo escritor - interioriza (e anterioriza) um público imaginário, que o aplaude e que, temporariamente, lhe basta.

Nota-se aí um processo em que o escritor fantasma vivencia, a princípio, duas personae: a sua própria figura autoral (uma espécie, digamos por enquanto, de eu-autor) e a daquele que lhe assina os escritos, um alter ego involuntário e apenas titulatório - ou comercial. O fato de ver os seus textos assinados por "grandes nomes" aumenta a vaidade, porque, já que a sua escrita é por eles encomendada e assumida, deve ser porque tem qualidade. Assim pensa, ironicamente, José Costa, expondo a banalidade de uma prática avaliadora à qual já nos acostumamos: aquela que admite que, se um texto está sob tal griffe, então deve ser um bom texto.

Considerando primeiramente que os nomes de autor são nomes próprios e que, portanto, carregam a mesma problemática que estes, Michel Foucault, em “O que é um autor?", indica alguns dos 
elementos de problematização. $O$ primeiro deles é o fato de que um nome próprio (e assim também um nome de autor) não constitui simplesmente uma indicação, indo além disso e caminhando para uma espécie de descrição. A essa analogia inicial entre nome próprio e nome de autor acrescenta-se ainda uma diferença básica: logicamente, um nome de autor agrega a si um conjunto de projeções que o nome próprio não agrega. Como exemplo dessas projeções temos as relações que se estabelecem entre o nome do autor e o conjunto da obra. Há signos que reenviam para o autor e que atuam diferentemente nos discursos providos da função de como atuam naqueles dela desprovidos. A função autor se dá na distância e na cisão, não fazendo sentido procurá-lo - ao autor - no escritor real. Há nos discursos providos da função uma pluralidade de eus, uma legião de personae ${ }^{13}$.

O coral de ventríloquos é esse conjunto de personae que se superpõem em Budapeste, emitindo vozes cuja fonte é impossível recuperar ou que não se sabe ao certo de onde vêm. Em vários níveis isso se dá: a iniciar pelo nome "Chico Buarque", impresso na capa e nomeando aquele que cria personagens, ou seja, empresta a eles a "sua" voz. Dos personagens a que dá vida (o clichê revela ainda uma vez o aspecto teológico aderido à função autoral), alguns funcionam, eles também, como verdadeiros ventríloquos, no universo da narrativa.

13 No conto do escritor norte-americano Paul Auster, intitulado "Cidade de vidro", o jogo intrincado de criação de personae extrapola o esquema tradicional autor-narrador-leitor. Ali, William Wilson (o pseudônimo é adotado pelo autor de romances de mistério Quinn, após ter perdido, na juventude, a parte de si que escrevia livros profusa e ambiciosamente), o autor, vai desaparecendo progressivamente em vista do personagem Max Work, também narrador, de quem Quinn se aproxima ao longo dos anos. "Na tríade de egos em que Quinn se transformara, Wilson servia como uma espécie de ventríloquo, o próprio Quinn era o boneco e Work era a voz animada que conferia um propósito àquela empresa" (AUSTER, 1999, p. 12). Quando tudo assim se estabelece, eis que surge, como personagem, Paul Auster, detetive cujos serviços são solicitados, por engano, através do telefone: "É o Paul Auster? perguntou a voz. - Eu queria falar com o senhor Paul Auster. - Não tem ninguém aqui com esse nome" (AUSTER, 1999, p. 13). Quinn esclarece a inexistência ali do tal detetive, mas, mediante a insistência do solicitante, decide assumir a identidade de Paul Auster e tenta desvendar o caso exposto, transformando-se num duplo do investigador. 
José Costa (Zsoze Kósta), por exemplo, comercializa os textos que escreve, ou seja, sua "voz" sairá pelas "bocas" de outros, como Kaspar Krabbe e Kocsis Ferenc. O Sr...., que escreve uma autobiografia assinada Zsoze Kósta, é mais um que doa sua voz, nesse caso sem que tenha sido solicitada, transformando Kósta, de ventríloquo, em boneco.

Quando Kósta lê a "sua" autobiografia, surpreende-se de repente do outro lado do jogo, feito personagem, marionete guiada pelos fios da narrativa do Sr....:

Eu me atrapalhava com a pontuação, perdia o fôlego no meio das frases, era como ler um texto que eu tivesse mesmo escrito, porém com as palavras deslocadas. Era como ler uma vida paralela à minha, e ao falar na primeira pessoa, por um personagem paralelo a mim, eu gaguejava (BUARQUE, 2003, p. 173).

Como num coro, as vozes se alternam, e, com elas, os papéis. Por exemplo, o mesmo Sr...., que José Costa lembra já ter visto no encontro de autores anônimos, mas que não consegue reconhecer, é, a princípio, o típico personagem "secundário". Surpreendentemente, é ele quem dá voz à narrativa de Budapest, falsa autobiografia de Kósta e outra faceta de Budapeste, o romance de Chico Buarque.

Pode-se, por um lado, afirmar que os personagens escritores de Budapeste são desdobramentos do nome de autor "Chico Buarque", maestro deste coral de ventríloquos e válvula motriz da escritura. José Costa (transformado, a partir de sua ida para Budapeste, em Zsoze Kósta) é o duplo (do) personagem que Chico Buarque criou e elevou, ficcionalmente, à condição de coautor (uma coautoria, é claro, em tudo diferente da tradicional, em que se supõe um projeto claro e a coincidência de intenções para a produção, a dois, de um texto uno e com conclusões coerentes) ${ }^{14}$. No texto de Chico Buarque a própria coautoria é uma invenção ficcional, ao menos até onde nos permitimos ir na nossa leitura.

14 Esse modo que interpretamos como "coautoria tradicional" se une a uma forma mais inusitada de parceria no livro 0 autor mente muito, em que os autores Carlos Sussekind e Fran- 
Nessa brincadeira de ventriloquismo ou superposição de vozes e personae, o coautor José Costa, por sua vez, empresta a Kaspar Krabbe sua escrita, fazendo suas as memórias daquele (e vice-versa). Assim, acontece ao empresário alemão perder os pelos do corpo e, mais que isso, a pele, a casca, como camarão, no momento em que um personagem criado dentro do texto por José Costa escreve a "sua" autobiografia. São "partes preciosas do corpo" que perde aquele que escreve; em especial o que se dedica a contar, a "passar para o papel" a sua vida. Mas se Kaspar Krabbe, que encomenda a primeira autobiografia a/de José Costa, não "perde", de fato, palavras, perde ele, então, a pele. Se, por outro lado, ele é invenção de José Costa, que é invenção de Chico Buarque, todos eles dispendem "partes preciosas", feito bichos que descamam ou folhas de papel sobrepostas, que irão afinal constituir e articular uma biografia, a escrita de uma vida, armando na folha de papel um novo homem, mas também uma espécie de monstro ou fantasma que é o ser compósito de palavras: palavras dispensadas, expulsas, defecadas no sentido freudiano da separação cotidiana, da perda ou do roubo.

A verdadeira descamação identitária que é o ato de escrita, ao expor um sujeito sempre sob um outro, e sob este ainda outro, toma vida no corpo do empresário alemão:

cisco Daudt da Veiga são também personagens. Trata-se de um livro escrito por medo de que o personagem Paulo Coelho lhes tomasse a ideia, segundo explicam logo no início. Vejase, por exemplo, o capítulo 5, "Em que Francisco fala": "Carlos Sussekind é esquisito. Você imagina um escritor cuja principal atividade é alterar os textos alheios? Imagina um livro escrito por dois autores? Quando ficar pronto ninguém saberá o que foi escrito por mim e o que foi escrito por ele. Este mesmo, que supostamente é meu em primeira pessoa, pode bem, na edição final, ter sido alterado por ele" (SUSSEKIND \& VEIGA, 2001, p. 47). A circulação confusa de personagens e autores, numa trama que inclui acontecimentos e nomes de personalidades conhecidas, esmaece as fronteiras entre ficção e realidade, envolvendo o leitor num jogo de múltiplas vozes cambiantes e lançando questionamentos sobre a função autoral: "E por acaso somos nós uns canalhas? Por que ele [Paulo Coelho] não o faria? Por acaso é algum santo? O ofício de escritor, aprenda de uma vez, consiste em copiar, plagiar, reinventar, roubar, disfarçar e publicar! Nil sub sole novum ("Não há nada de novo sob o sol"). Além do que, só existem 36 situações dramáticas. Tudo o mais é recombinação" (SUSSEKIND \& VEIGA, 2001, p. 189. Conteúdo dos colchetes inserido por mim). 
O alemão não tinha cabelos, nem sombra de barba, nem sobrancelhas, era perfeitamente glabro. Sem ser velho, tinha a pele do rosto ressequida, provável seqüela do sol do Rio, sete verões com a pele a se soltar da pele a se soltar da pele até chegar a essa, uma pele com um quê de papel, uma casca provisória que foi ficando (BUARQUE, 2003, p. 28, grifo meu).

Kaspar Krabbe alude, pelo sobrenome, tanto ao aspecto físico do empresário - "um homem louro e cor-de-rosa" (BUARQUE, 2003, p. 29), "perfeitamente glabro" (BUARQUE, 2003, p. 28) e com a "pele escorregadia” (BUARQUE, 2003, p. 87) como camarão (alemão: krabbe) - quanto à conotação popular que liga o crustáceo à obtusidade (aquele que "tem fezes na cabeça", portanto não consegue relatar sequer as próprias experiências),

Kaspar Krabbe traz também, no nome, a designação do personagem principal do teatro alemão de fantoches (Kasperle, daí Kasperle-Theater), destacando a sua condição de boneco de ventríloquo em Budapeste, a despeito de ser ele quem encomenda os trabalhos de um ghost writer (escritor-fantasma), expondo a reversibilidade a princípio insuspeitada desses papéis, ou reinaugurando a questão de qual dos dois - escritor fantasma ou fantasma escritor - será o mais espectral.

Não seria necessário a José Costa ter criado, para a biografia de Kaspar Krabbe, um narrador que fosse escritor, mas ele o cria. Claro que a relação está de antemão subentendida, já que se trata de uma autobiografia, e um texto que se lê (e não se ouve, por exemplo). Mas, considerando-se que a maior parte das "autobiografias" é hoje escrita por ghosts, o que o ghost José Costa faz, ao aderir ao seu personagem a função de escrita, é ressaltar essa fissura, e de um modo que, dada a atual naturalização do ato de terceirizar a escrita das memórias, não arrola a ironia alcançável tempos atrás.

O Sr...., único personagem ironicamente sem nome próprio em meio àquele teatro de máscaras ficcionais e excesso de nomes, inventa a autobiografia de Zsoze Kósta, ação que de certa forma o aproxima (a ele, o Sr....), em sua "função", do seu criador (seu, de José Costa e de Zsoze Kósta), o autor "Chico Buarque”. 
Por fim, o escritor húngaro Kocsis Ferenc ${ }^{15}$ - aquele que, afinal, representa uma outra faceta de José Costa, sendo este o prosador e aquele o poeta, este o anônimo e aquele o renomado, este o ascendente e aquele o decadente, este o criador e aquele o receptor dos seus primeiros poemas em magiar - leva ele próprio, no nome, um anagrama fonético imperfeito de Francisco (como o Buarque de Hollanda): Kocsis Ferenc: leia-se primeiro o sobrenome, sutilizando a pronúncia do primeiro $e$ e transformando o segundo em $a$.

Em seguida, ligado ao sobrenome, leia-se o nome, de trás para diante, emudecendo o k final: Franc sisco. Nessa leitura especular (como a que se faz do livro, desde a capa) encontra-se mais esse duplo, um outro Francisco, cindido em dois ${ }^{16}$. De conceito todo-poderoso, onisciente e onipresente, o nome do autor se quebra ao meio, chegando à dimensão de um cisco entre os demais nomes criados no texto.

A estratégia do anagrama onomástico (inclui-se aí também Kriska, o nome da mulher húngara de Kósta) é reforçada por uma série de outras expressões anagramáticas espalhadas pelo texto, geralmente nomeando livros e poemas de autoria desses vários personagens autores. São alguns deles: "Tercetos Secretos" (BUARQUE, 2003, p. 34), "Sinfonia das Ninfômanas" (BUARQUE, 2003, p. 139), "Intróito Ornítoco" (BUARQUE, 2003, p. 139), "Crepúsculos Especulares" (BUARQUE, 2003, p. 140), "Rapsódia da Diáspora" (BUARQUE, 2003, p. 140) e "Apoteose dos Poetas" (BUARQUE, 2003, p. 145), além do hotel "Zacarias" (BUARQUE, 2003, p. 142) ${ }^{17}$ e dos romances 0 Ginógrafo e O Naufrágio, que José Costa em certa ocasião confunde. Também

150 nome rende homenagem a dois dos jogadores da seleção húngara de futebol de 1954: Ferenc Puskás e Sándor Kocsis. Os demais atletas do mesmo time (Gyula Grosics, Gyula Lorant, Jeno Buzanski, Josef Bozsik, Joszef Zakárias, Mihaly Lantos, Mihaly Toth, Nandor Hidegkuti e Zoltán Czibor) têm seus nomes distribuídos por outros personagens, rua, avenida e hotel.

16 Ainda que se suponha que, nesse caso, Chico Buarque não se tenha dado conta do meio-anagrama criado, é já há muito conhecido o seu gosto por jogos de linguagem desse tipo, sendo ele inclusive considerado o autor do mais longo palíndromo da língua portuguesa: "Até Reagan sibarita tira bisnaga ereta" (Disponível em <http://chicobuarque.uol.com.br/>. Acesso em: 16 set. 2007).

17 Espécie de espelho de Alice, aqui marcando a mágica passagem para a paradoxal "nome- 
o número do quarto de hotel em que Costa se hospeda no Rio de Janeiro, palindrômico, pode ser lido de trás para diante: “o 707 vivia às escuras" (BUARQUE, 2003, p. 161). Os anagramas formam a parcela propriamente linguística do conjunto de relações especulares inaugurado com a disposição dos termos na capa do livro, passando pelos duplos personagens autores José Costa e Zsoze Kósta, pelas suas duplas vida (no Brasil e na Hungria) e personalidade. E mesmo Vanda, a mulher brasileira de José Costa, tem uma gêmea perfeita, chamada Vanessa ${ }^{18}$.

A própria cidade que ambienta as fugas de José Costa do Brasil - e de si - é um duplo entre os outros em que se desdobra(m) o(s) livro(s), sendo uma união política de Buda e Peste, divididas pelo rio, ou, a depender do ponto de vista, unidas pela ponte. Do seu primeiro sobrevoo pela cidade, Costa relembra: "eu pensava que Budapeste fosse cinzenta, mas Budapeste era amarela” (BUARQUE, 2003, p. 11), enquanto Kósta, quando a enxerga, afirma: "engraçado que eu imaginava Budapeste amarela, mas eratoda cinzenta” (BUARQUE, 2003, p.51).

Como última duplicidade, o romance Budapest tem início, no final de Budapeste, com as mesmas palavras que deram início a este último: "Devia ser proibido debochar de quem se aventura em língua estrangeira” (BUARQUE, 2003, p. 5. e, igualmente, p. 172-173). Mais

ação do inominado", momento de glória dos autores anônimos no encontro que naquele ano se realiza na Hungria,e quando cada um deles enumera, ao microfone, os nomes dos autores para os quais escreveram como ghosts, a placa com o nome do hotel Zacarias é avistada por José Costa numa de suas deambulações por Budapeste. Ele entra e simula ter ali uma reserva de quarto, estratégia já utilizada anteriormente para conseguir vaga, acusando tacitamente o hotel de desorganização. Só que, desta vez, quando Costa anuncia seu nome, o atendente diz que estavam a sua procura. É assim, quase por encanto, que José Costa descobre estar inscrito para o congresso de autores anônimos que acontece ali naquele momento.

18 Nesse verdadeiro labirinto de duplos e simulacros, cabe ressaltar a descrição inicial do poeta Kocsis Ferenc, que o mostra, magnificamente, como a aparência da aparência: "Ali se postava um homem longilíneo e meio encurvado, parecendo ser mais jovem do que aparentava, porque parecia um moço com ares de velho" (BUARQUE, 2003, p. 36, grifos meus). A narrativa põe ao avesso o personagem para descobrir-lhe, de novo, a superfície. Afinal, o que significa parecer ser mais jovem do que se aparenta? Do mesmo modo que não se acha mais o sujeito monolítico por detrás da máscara, também não se encontra simplesmente o "autor" por detrás do "personagem", nesse universo de papel. 
que livro dentro de livro - temática metalinguística já reiterada pela literatura moderna -, um livro literalmente saindo do outro.

A capa de Budapest, cuja autoria se imputa a Zsoze Kósta, é descrita como "furta-cor"19 (BUARQUE, 2003, p. 167), o que aponta sua vocação cambiante e inaugura, ao mesmo tempo, uma rede vertiginosa de simulacros de simulacros. Já a cor ocre do livro de Chico Buarque, mistura de cinza e amarelo, condensa as cores que José Costa e Zsoze Kósta, respectivamente, percebem como sendo as da cidade de Budapeste, além de ser também a cor que José Costa percebe na capa de $O$ Ginógrafo, primeiro romance que escreve, assinado por Kaspar Krabbe, relação cromática que arrasta este último livro e seu suposto autor para a rede de simulacros, expondo que também o romance da "escrita na pele" - 0 Ginógrafo20 - se relaciona com este outro, chamado Budapeste, ainda mais que, em ambos, a ligação mulher-escrita é inarredável.

De certo modo declara-se que todas essas escritas sobrepostas tratam de uma mesma questão, vista de vários ângulos, que é a da própria escrita, em sua ligação com o feminino e contrariamente às posições masculina e paterna que tradicionalmente reivindicam as relações de autoria e de autoridade, consideradas típicas do discurso lógico e do domínio da fala.

José Costa, que assume com Chico Buarque a coautoria ficcional do livro, nascendo já duplamente personagem (como coautor criado pelo "autor" e como personagem propriamente dito), será depois, internamente à narrativa: autor anônimo, narrador, personagem e autor de livros que não assinou, tanto quanto "assinante" de livros

19 "Furta-cor. Que apresenta cor diversa, segundo a luz projetada; cambiante. A cor cambiante" (FERREIRA, 1994, p. 955).

20 A linha de propriedade que liga, para José Costa, a mulher e a escrita, explicita-se no nome desse "seu" primeiro romance, surgido de uma crise a um tempo financeira, criativa e afetiva, cujo narrador escreve no corpo das mulheres, algumas das quais recebem dinheiro para que sua pele possa ser usada "como papel". o corpo aparece como meio de "inspiração" para a escrita (marcada diretamente na carne, nesse caso, e portanto antes como uma forma de transpiração): "a inspiração é em primeiro lugar esse ponto puro em que ela falta”, disse certa feita Derrida acerca de Artaud (DERRIDA, 1971, p. 111). 
que não escreveu, inclusive o livro chamado Budapest. O Sr... se revela então o "verdadeiro" (sempre aspeado, bem entendido) autor de Budapeste, já que o livro que o leitor tem em mãos, por um jogo interno da narrativa, desponta agora como uma outra face de Budapest, se dando não somente o contrário, como vimos mostrando.

É o Sr... o "real" coautor do livro Budapeste, dividido com Zsoze Kósta, sendo este o personagem autor para quem aquele cria uma história em primeira pessoa. E se é ele o nome vero-ficcional à capa do livro furta-cor, é ele, de certo modo, o tal "Chico Buarque", agora transformado em personagem de José Costa, que por sua vez é criação do Sr...., correspondente ficcional de Chico Buarque.

Se ao longo da história da literatura o contraponto do personagem - ser ficcional e interior à narrativa - era um "senhor" (cidadão real e externo a ela), a simplicidade dessa relação é questionada pela existência daquele misterioso Mr... que caminha de dentro da narrativa para fora dela, à medida que sua função de criador se expõe, igualando-o a Chico Buarque, enquanto o nome "Chico Buarque" de certa forma se "interioriza" ou se ficcionaliza, transformado em nome de personagem, a partir do momento em que se iguala, enquanto autor, aos seus personagens autores.

Assim também Zsoze Kósta e o Sr... se entregam um ao outro nas suas ficções, como personagens de uma dupla ficcionalização em que não atuam nem "simplesmente" como autores, nem como meros personagens, mas antes numa deambulação identitária que abala o estatuto autoral enquanto dependente apenas do nome com que nos deparamos na capa do livro. Fica claro que, para que se cumpra o jogo reversivo proposto, a participação do leitor é fundamental, já que é somente quando terminado o percurso de leitura que se concluem alguns lances dessa partida. "O nascimento do leitor tem de pagar-se com a morte do Autor" (BARTHES, 1988, p. 53). Acrescentamos: a atuação do leitor é parte do jogo de máscaras em que está envolto o autor.

Ao final da leitura de Budapeste percebe-se que este livro já se encontra curiosamente incluso naquele outro - Budapest - que lhe é interno. Também se nota que através do Sr... o personagem José 
Costa passa a ter, num certo sentido, muito mais "realidade" que a assinatura "Chico Buarque", posta na capa; afinal, é da história de José Costa que se trata e é dele que melhor conseguimos nos aproximar, graças aos detalhes de "sua" bioficção $0^{21}$, que acompanhamos ao longo da história. Podemos dizer de José Costa o que ele mesmo diz de Kriska, ao ler para ela a "sua" autobiografia... "que pelo menos estava no livro desde o início" (BUARQUE, 2003, p. 171-172).

A assinatura, que lança um espectro originário sobre o livro, arrasta consigo uma posterioridade também originária, o retardo preparado pelas injunções desenvolvidas no texto sobre o tema. Tendo lido o livro e contemplando-lhe agora a capa, o leitor é levado a estranhar a ascensão de José Costa, de ghost writer a autor (ou coautor) do romance Budapeste. Essa movimentação abala o estatuto que mantinha, magicamente, o ente Chico Buarque (ou, dito mais acertadamente, seu nome) um degrau acima de suas personagens, embora ele, enquanto autor, só exista graças a sua ficção: paradoxo da autoria e complexidade da assinatura. O jogo de coautoria real-ficcional posto em relevo na capa encerra um texto que trata de questões importantes relacionadas à escrita.

Uma cena possível agora seria: terminada a leitura, fechando o livro, o leitor é convocado a procurar algumas respostas para aquelas questões, ou a passar a limpo o "Chico Buarque" inicial. Tudo isso recoloca a questão do sujeito originário: "Como, segundo que condições e sob que formas, algo como um sujeito pode aparecer na ordem dos discursos? Que lugar pode o sujeito ocupar em cada tipo

210 conceito de bioficção é usado aqui como uma radicalização daquele criado por Alain Buisine. Para o escritor francês, bioficção seria "o texto literário em que o quadro narrativo se junta ao da biografia, definida como um relato cronológico da vida de um indivíduo particular. Ou seja, textos que usam a vida humana como tema, mas que fazem do tempo de duração dessa vida a forma básica do relato" (Disponível em <http://www.correioweb. com.br/politica/>. Acesso em: 03 mar.2004). Na esteira de Evando Nascimento, que defende e difunde "sem complacência" o uso do termo bioficcionalidade, a nuance que propomos designa não mais o simples aproveitamento de uma instância (real) por outra (literária), mas o entrelaçamento radical, na escrita, dessas instâncias apenas a priori delimitáveis. Nascimento resume: "nada de literatura antes da vida, nada de experiência vital sem escrita que a suplemente e plenifique” (NASCIMENTO, Cult, n. 51, 2001, p. 10). 
de discurso, que funções pode exercer e obedecendo a que regras? Em suma, trata-se de retirar ao sujeito (ou ao seu substituto) o papel de fundamento originário e de o analisar como uma função variável e complexa do discurso" (FOUCAULT, 1992, p. 69-70). Afinal, assim como não existe unidade simples para a instância autoral, também "não existe sujeito absoluto" (FOUCAULT, 1992, p. 84).

A partir de então, a existência do personagem José Costa interfere na concepção de autor. Quando lhe imputam a autoria da falsa autobiografia, ele tenta provar que não escreveu o livro, ficando claro assim, pela via inversa, que a indiferença inicial quanto ao destino de seus textos não se sustenta, especialmente quando está em jogo, mais que o destino de sua escrita, o futuro de seu próprio nome. Ressalta a sugestão de que mais difícil que não poder assumir o que se escreve, é ser obrigado a assumir-se o que não se escreveu.

Quando José Costa narra o momento em que encerra o romance autobiográfico encomendado por Kaspar Krabbe, a sensação que descreve, ao ter de entregar o livro ao seu futuro "autor", é parecida com a que relata qualquer escritor ao dar a público uma nova obra: "e abrir mão de um livro pronto e acabado era sempre doloroso, mesmo para um profissional calejado como eu" (BUARQUE, 2003, p. 40). Diante dessa sua confissão, cabe uma pergunta acerca da sensação do escritor de escrever um texto e ter de entregá-lo a público sob um nome próprio, que é o seu, mas que de forma alguma corresponde plenamente àquela subjetividade complexa que o concebeu. Não haveria aí uma sobreposição de personae, nessa contínua descamação identitária que é a produção ficcional? E que dizer da pretensão vigente ainda hoje, entre alguns leitores e críticos, de que, no resultado artificial do exercício da escrita, siga fielmente o feixe de experiências do "sujeito" que a concebeu? Quais seriam, por exemplo, na vida de um escritor, as experiências com valor, força ou importância suficientes para serem selecionadas a fazer parte de uma narrativa? A própria seleção dos "melhores momentos" não denotaria um certo predomínio do escrito sobre o vivido, já que aquele exige deste, para registro, o seu melhor, não aceitando menos que isso? Não estarão 
antes emaranhados no ato de escrita o vivido e o inventado, o vivido (re)inventado quando transformado em escrita, e o inventado vivido no momento da escrita - e da leitura?

Os pontos destacados até aqui ressaltam não apenas a complexa relação do produtor com o texto, ou as diferenças entre o nome próprio e o nome de autor, mas também a questão da propriedade em geral. A princípio José Costa aparenta não alimentar qualquer apego aos textos que escreve, não lhe importando inclusive por quem serão assinados, essa parte das resoluções ficando ao encargo de Álvaro, seu sócio. Adiante no entanto regozija-se com o fato de seus escritos serem assumidos por pessoas renomadas no meio intelectual e, por fim, toma-o a sensação de propriedade, demonstrada em ciúmes irrefreáveis. Sempre porém o sentimento de posse estará ligado à ideia de perda da companheira, a aproximação mulher-escrita se dando pelo fato de os dois escritores para quem vende os seus textos de maior sucesso (O Ginógrafo e Tercetos Secretos), respectivamente Kaspar Krabbe e Kocsis Ferenc ${ }^{22}$, entrarem em contato com Vanda, sua mulher brasileira ${ }^{23}$, e, ao menos na imaginação de Costa, por ela se interessarem ou nela despertarem interesse.

Inclusive, ao perceber o encantamento de Vanda com o romance que escrevera sob encomenda para o empresário alemão, Costa quebra os preceitos éticos que viera afirmando, de jamais tornar pública a real autoria dos escritos que comercializa, e revela ser o verdadeiro autor de 0 Ginógrafo.

\footnotetext{
22 Assim como na obra de Franz Kafka, proliferam em Budapeste nomes de personagens iniciados por $k$ (Kaspar Krabbe, Kocsis Ferenc, Kriska e Kósta), opção que, do mesmo modo que no autor tcheco, aponta tanto para o desdobramento de "eus" do autor quanto para a diluição identitária de sujeitos menores do que a "máquina" que os envolve e movimenta como peças de uma engrenagem, embora não haja aqui um nome de autor iniciado em $k$, como lá. Aqui, personagens em k são como ecos daqueles que a máquina de escrita kafkiana lançou ao mundo por meio do seu patuá (Conferir DELEUZE \& GUATTARI, 1977).

23 A expressão "minha mulher", presente onde por vezes poderia ser usado o nome Vanda, é repetidamente cunhada, no romance, com enfáticos pronomes possessivos. 0 amplo sentimento de posse que José Costa experimenta e que consegue temporariamente reprimir no que diz respeito ao seu objeto de trabalho, a escrita, vem à tona de forma incontrolável quando entra em questão a relação com a mulher.
} 
Na Hungria, ao contrário, "sofrendo" a publicação de um romance estranho sob seu próprio nome, tenta provar a Kriska e às demais pessoas presentes na noite do lançamento não ser ele o autor, mas não é levado a sério: "O autor do meu livro não sou eu, me escusei no Clube das Belas-Letras, mas todos me fizeram festa e fingiram não me ouvir, talvez porque, como se diz, eu falasse de corda em casa de enforcado" (BUARQUE, 2003, p. 170, grifo meu). Suas palavras finais assumem no contexto uma conotação de início insuspeitada: mais que indicar que o uso dos serviços de escritor-fantasma é disseminado, aponta para uma outra questão, inerente à própria escrita, que é a paradoxal dissimulação que faz com que o escritor não se sinta plenamente representado na sua escrita, o que entretanto não lhe permite negá-la. Daí a expressão contraditória: "o autor do meu livro não sou eu", que insere sutilmente, na ficção, mais uma consideração acerca dos processos de escrita e publicação.

A frase, reiterada adiante em "não poderia ser eu o autor de um livro que trouxesse meu nome na capa” (BUARQUE, 2003, p. 172), resume com humor o pensamento desconstrutor de uma lógica de mercado e de direito positivo que toma como suficiente afirmadora de autenticidade (e, de um modo vago, de originalidade) a assinatura que se apõe a um texto, geralmente no documento de contrato entre editor e autor. Pelas várias razões enumeradas, não há simplicidade na assinatura, nem garantia, por meio dela, de autenticidade. A problemática vai além do estranhamento daquele que se acostumou ao oposto, a ver os livros que escreveu serem publicados sob assinaturas de outrem. A clivagem é percebida e tratada com ironia pelo personagem autor de Chico Buarque.

Aliás, de um modo desesperado, Costa tenta romper instantaneamente o esquema no qual e pelo qual sempre trabalhara. Ao deparar-se com seu nome na capa de um livro que não escreveu, vêm à tona, de mistura, diversos sentimentos, entre eles o ciúme, pela sensação de "perda" não mais da escrita, mas do próprio nome. Nesse ponto também não se pode ignorar que sua relação com o feminino esteve sempre intimamente ligada, se não condicionada, ao vínculo 
com a linguagem. No seu universo, o produto do trabalho e o objeto de desejo são ambos envoltos pelas malhas da propriedade, emaranhados os sentidos de produção e reprodução, analogia que reitera a ligação entre o pai da fala e o inseminador, fundadora do falogocentrismo ocidental descrito por Derrida em alguns textos, especialmente em A farmácia de Platão. O discurso e a reprodução se ligam pela imagem oculta do sêmen: o pai é gerador de filhos por meio dele, assim como aquele que fala insemina o discurso com suas ideias (donde seminário). A ideia de disseminação do lógos (o discurso vivo, a fala) é mesclada à da ejaculação pela potência engendrante de ambos.

Nesse sentido é significativo que seja Kriska, uma mulher enfim, quem ensina a José Costa o magiar, segundo ela própria uma língua que "não se aprende nos livros" (BUARQUE, 2003, p. 60). No convívio com Vanda, de modo sintomático, a ausência de diálogo resulta num filho. Quando relata a fecundação, percebe-se que a sensação que tem José Costa, lançando "sua semente", é de uma temporária perda de amor próprio, comparável àquele pseudodesprendimento inicial que demonstrava ao entregar seus textos para serem publicados sob nome alheio: após o encontro anual de escritores anônimos, de que sai arrasado e no auge da crise identitária, ele conta que: "Viajei trinta horas com o pensamento em branco, e quando pedi para dormir em casa, a Vanda nada me perguntou, me serviu uma sopa e alinhou meus cabelos. Foi aí que, despojado de amor-próprio, engravidei a Vanda" (BUARQUE, 2003, p. 22).

A experiência de reprodução, assim como a de produção (escrita), acarreta uma certa perda ou espalhamento do eu. $\mathrm{O}$ ato de engravidar a mulher resulta de uma crise de esvaziamento da identidade, um traço esquizoide que reaparece, sintomaticamente, a cada (raro) ataque de prolixidade autopromocional e revelador da identidade de José Costa, crises geralmente ocorridas no encontro anual de autores anônimos. São ambos, a escrita e o engendramento, substitutos da fala oculta, difícil, que não pode ser assumida e que, por isso mesmo, quando se mostra é aos borbotões, de forma incontrolável e desordenadamente, como nestas duas cenas: 
Desculpando-me por me expressar em português, fiz um resumo do meu currículo, mencionei minha tese de doutorado, fui aplaudido (...) Em seguida expliquei o contexto de um ou outro trabalho, fiz alusão a personalidades que me deviam favores, daí a pouco estava a desembuchar fragmentos embaralhados de todos os artigos que me vinham à cabeça. Já era uma compulsão, eu fervia, falava, falava, teria falado até o amanhecer se não desligassem a aparelhagem de som. Ao ver a sala vazia e o elevador lotado, subi de um fôlego sete lances da escada; eu estava leve, eu estava magro, lá em cima me veio a sensação de ter ficado oco. A náusea (...) (BUARQUE, 2003, p. 20-21). (...) anunciei os Tercetos Secretos, poema de minha autoria outorgado ao emérito Kocsis Ferenc, com prefácio do venerando professor Buzansky Zoltán. Eu tencionava ler, mas não li o prefácio, um autêntico Buzansky, cujo estilo tão superior ao seu poderia humilhar o Sr.... Preferi humilhá-lo com a poesia, arte que ele ignorava, e que o faria sofrer muito mais por não saber onde lhe doía. Eu declamava os versos lentamente, havia palavras que eu quase soletrava, pelo prazer de vê-lo se remexer na cadeira. (...) Era para o Sr.... que eu me exibia, e para ele fiz uma mesura ao encerrar o poema, debaixo de bravos e vaias. Levei horas para chegar com minha mala de mão ao sétimo andar, bufando, me amparando nas paredes. Entrei no quarto com ânsias, fui à privada, enfiei o dedo na garganta, mas eu não jantara, não tinha o que vomitar (BUARQUE, 2003, p. 145-146).

Tendo ficado "com o pensamento em branco" após uma dessas crises, o escritor agora precisa "inseminar", escrever. Precisa criar, produzir... e reproduzir. Quando não surge um livro, surge um filho. E um filho (Joaquinzinho) que é já meio-órfão, como tudo o que ele produz, como os textos não assinados. E se José Costa cria e procria, é sempre na tentativa de preencher uma lacuna, inventando - pela escrita e por meio da prole - mais vidas para si.

Com Kriska também não flui a comunicação oral, apesar do esforço inicial de Costa para aprender-lhe o idioma. Quando enfim o conhece com perfeição, seu diálogo com a professora húngara é impossibilitado por razões do campo afetivo, e ele continuará, na Hungria, a utilizar-se basicamente da escrita ${ }^{24}$ - e com surpreendente mestria.

24 Os diálogos (o lógos), a "fala" em geral, resumem-se a pouquíssimas ocasiões na narrativa, o que representa a abolição dessa que é uma das formas tradicionalmente constitutivas do "romance". Por isso e por outras razões, o nome romance, na capa de Budapeste, configura 
A experiência radical de superposição de vozes realizada em Budapeste vai além de um mero jogo em que se interroga sobre as instâncias narrativas tradicionais. Por meio de uma sequência de simulacros que beira o fantástico - opção em tudo compatível com o trabalho de escrita ali desenvolvido -, o texto de Chico Buarque traz à tona, problematizando-as, questões relacionadas à produção de livros e a sua inserção no mercado hoje. Ao mesmo tempo, induz a perguntas como: o que é um autor; até que ponto é possível seccionar autor, narrador e personagem; de que modo se emaranham, na escrita, o inventado e o vivido; como é possível falar-se, ainda hoje, em algo como um sujeito da escrita; que envolvimentos legais acarreta a comercialização de livros escritos sob encomenda e no anonimato?

Ao trabalho escritural não mais satisfaz pôr em causa os estatutos de real e ficcional, a partir da criação de um universo fantástico, hiper ou surreal. Os fatos narrativos se dão num território fronteiriço cujas partes já não é possível delimitar com clareza, encaminhando para a vivência de outros, novos anseios, no contato com a escritura. A problematização da função autoral faz parte desses anseios, num tempo em que o "autor" (termo que mais que nunca é preciso manter em suspensão) não mais necessita descortinar experiências pessoais diante do leitor, nem mesmo dissimulá-las a todo custo. Ou então necessita, como nunca, disso e daquilo, situação que desestimula qualquer perscrutação que queira trabalhar pela separação simples dos campos do real e do ficcional.

mais uma armadilha para o leitor que penetra esse estranho universo. 


\section{REFERÊNCIAS}

ACCIOLY, Maria Inês de Araújo Jorge. Ghost writer: o autor à sombra. Rio de Janeiro: UFRJ/ECO, 2001.

AUSTER, Paul. A trilogia de Nova York. Tradução Rubens Figueiredo. São Paulo: Companhia das Letras, 1999.

BARTHES, Roland. A morte do autor. In: . 0 rumor da língua.

Tradução António Gonçalves. Lisboa: Edições 70, 1987, p. 49-53.

BARTHES, Roland. Aula. Tradução Leyla Perrone-Moisés. São Paulo: Cultrix, 1989.

BARTHES, Roland. et al. Literatura e Realidade. Tradução Tereza Coelho. Rio de Janeiro: Publicações Dom Quixote, 1984.

BUARQUE, Chico. Budapeste. São Paulo: Companhia das Letras, 2003.

BUARQUE, Chico. Fazenda modelo: novela pecuária. Rio de Janeiro: Civilização Brasileira, 1985.

CONY, Carlos Heitor. Quase memória: quase-romance. São Paulo: Companhia das Letras, 1995.

DELEUZE, Gilles \& GUATTARI, Félix. Kafka: por uma literatura menor. Tradução Júlio Castañon Guimarães. Rio de Janeiro: Imago, 1977.

DERRIDA, Jacques. A escritura e a diferença. Tradução Maria Beatriz M. Nizza da Silva. São Paulo: Perspectiva, 1971.

DERRIDA, Jacques. A farmácia de Platão. Tradução Rogério da Costa. São Paulo: Iluminuras, 1991. 
DERRIDA, Jacques. Papel-máquina. Tradução Evando Nascimento. São Paulo: Estação Liberdade, 2004.

DERRIDA, Jacques. Salvo o nome. Tradução Nícia Adan Bonatti.

Campinas: Papirus, 1995.

DERRIDA, Jacques. Torres de Babel. Tradução Junia Barreto. Belo Horizonte: Editora UFMG, 2002.

FERREIRA, Aurélio Buarque de Holanda. Novo Dicionário Aurélio de Língua Portuguesa. Rio de Janeiro: Nova Fronteira, 1994.

FOUCAULT, Michel. O que é um autor? Tradução António F. Cascais e Edmundo Cordeiro. Lisboa: Vega, 1992.

NASCIMENTO, Evando. Os favos da (quase) poesia: a poesia nômade de Waly Salomão. Revista Cult , São Paulo, n. 51, out. 2001, p. 10-13.

PLATÃO. Fedro. Tradução Pinharanda Gomes. Lisboa: Guimarães e Cia Editores, 1981.

SAORÍN, José Luis. A curiosa história do editor partido ao meio na era dos robôs escritores. Tradução Luis Reyes Gil. Rio de Janeiro: Relume Dumará, 2005.

SUSSEKIND, Carlos \& VEIGA, Francisco Daudt da. 0 autor mente muito. Rio de Janeiro: Dantes, 2001. 



\section{CAPÍTULO 2}

RADUAN NASSAR - AS RELAÇÕES ENTRE PODER E PRAZER 
[...] só os tolos, entre os que foram atirados com displicência ao fundo, tomam de empréstimo aos que estão por cima a régua que estes usam pra medir o mundo; como vitimas da ordem, insisto em que não temos outra escolha, se quisermos escapar ao fogo desse conflito: forjarmos tranqüilamente nossas máscaras, desenhando uma ponta de escárnio na borra rubra que faz a boca; e, como resposta à divisão em anverso e reverso, apelemos inclusive para o deboche, passando o dedo untado na brecha do universo [...]

Raduan Nassar. Lavoura arcaica. 
No capítulo de abertura de Um copo de cólera, uma cena funciona como pródromo sintomático do desfecho, constituído de um discurso que se perfaz entre o poder e a sexualidade. Na cena final se expõe mais efetivamente a urdidura desses dois elementos, unidos desde o início e que apenas por força de abstração podem ser separados na busca de um maior entendimento dos mecanismos ou estratégias de poder que perpassam o discurso dos personagens. A cena de que falamos faz parte do capítulo denominado "o esporro" e repete, de alguma forma, a primeira cena erótica do texto, intitulada "na cama". Queremos destacar, desde já, que na cama e fora dela se realiza o que poderíamos chamar uma experiência de ejeção, numa reverberação, pelo texto, de elementos que, suplantados anteriormente, retornam na diferença ao longo da narrativa.

Neste ponto será o caso de se perguntar como é possível falar de diferentes estratégias de força partindo de uma imagem como a da ejeção, que a princípio seria o resultado de uma força que se direciona inequivocamente de dentro para fora. Uma imagem que por si só não pode representar a ideia de poder como se entende já há algum tempo, especialmente a partir dos estudos do pensador francês Michel Foucault. Mesmo porque uma simples hierarquização ou uma completa ordenação centro-periferia jamais existiu. Então, como comparecem, na ficção nassariana, as representações de poder? E de que formas se dá o embate de forças nas falas e nos atos dos personagens? A leitura de uma microfísica do poder na narrativa auxiliará na tentativa de conhecer essas estratégias e representações. Para tanto, recorremos justamente às combinações entre poder e sexo apontadas por Foucault e ligamo-las sempre a aspectos da ficção nassariana que explicitem essas relações. O paradigma da ejeção ressalta então por acarretar a ideia de força não totalmente controlável por um sujeito, contudo passível de ser observada a partir de um determinado ponto de vista, que pode ser o do próprio sujeito que "ejeta", como acontece em Um copo de cólera.

Porém, o conceito a que recorremos, nesse caso, não deve ser encarado somente do âmbito da impressão física. Nesta leitura do 
texto de Nassar, o termo ejeção é priorizado por perfazer no mínimo uma ambiguidade que o deixa a meio caminho entre o sexo e outro tipo de força (ou poder). Se a princípio a força capaz de gerar uma ejeção (ejaculação, esporro) parece fechar um ciclo sensível e perceptível ao fim de um movimento e com uma exteriorização (de sêmen, de um grito, de um projétil, de um piloto), a circulação dessa mesma força que aí se inicia não finda simplesmente com o término visível ou audível do movimento de exteriorização. Um prosseguimento ou retorno, mais ou menos controlável, de forças - portanto de poder - devem ser esperados. E é por se realizarem, no texto, várias "ejeções", sendo que nenhuma delas encerra o risco da concepção, que nos servimos aqui da interseção de ideias que o termo instaura: a primeira experiência de ejeção é narrada no capítulo denominado "na cama" e descrita em parte como prática onanista. Uma segunda é a ejeção verbal que domina o capítulo intitulado "o esporro". Uma terceira é apenas imaginada pelo personagem masculino e descrita como uma investida marcial. Adiante voltaremos a nos referir a cada uma delas.

Após a primeira cena erótica - a cena de sexo propriamente dita, realizada na cama e logo no início do texto -, inicia-se "o esporro", essa longa ejaculação verbal que se encerra com a terceira ejeção, virtual e bélica. É como se cada um desses "orgasmos", reais ou imaginários, viesse suplementar um orgasmo anterior, na linha de um desejo sempre, necessariamente insatisfeito. A intensidade que o "diálogo" entre os personagens aos poucos vai tomando na cena do "esporro" verbal desemboca ciclicamente em outra cena que, nos domínios do texto, repete aquela narrada no início. Desse modo a sexualidade corta transversalmente a narrativa, a ideia do "corte" esclarecendo a recorrência constante do narrador ao paradigma da representação, com tudo o que ele encerra de artificialidade e de cálculo. Nesse sentido é importante notar que, atuando sexualmente junto à parceira, o personagem masculino centra a narração na observação do próprio corpo, pondo em ação assim uma forma de auto-erotismo, apenas ampliando o prazer pelo toque e pelo olhar do 
outro. A parceira funciona como instrumento duplicador das sensações que encerra o contato dele com o próprio corpo, apresentando-se assim como meio para o alcance do gozo: "Por uns momentos lá no quarto nós parecíamos dois estranhos que seriam observados por alguém, e este alguém éramos sempre eu e ela, cabendo aos dois ficar de olho no que eu ia fazendo, e não no que ela ia fazendo"25. 



\section{O PODER DO PRAZER}

O personagem que conduz a narrativa e que pensa vir guiando a relação sexual aparenta ter o domínio da situação do enunciado, tanto quanto da enunciação. Contudo, para entender dessa forma os acontecimentos que se dão em Um copo de cólera, seria preciso ignorar aspectos importantes do embate físico e verbal entre os protagonistas. A escolha da expressão "o esporro" para intitular um capítulo importantíssimo da narrativa já sinaliza para as duas categorias: a discursiva e a sexual. Que a questão do poder é relevante em Um copo de cólera, portanto, não se pode negar. Mas uma leitura do poder como força linear, fechada em negações, interdições e hierarquizações, não acompanharia o movimento dos personagens nassarianos. $\mathrm{O}$ embate de forças em que se encontram é algo que deve gerar muito mais que um vencedor e um vencido. Embora a fala de cada um pareça ser guiada por um desejo de lançar a última palavra, nota-se logo a falsidade dessa impressão, já que cada assertiva, por mais contundente que possa parecer, solicita sempre uma outra, de força igual ou superior, que valorize suficientemente o investimento provocador:

[...] estava longe de me interessar pelos traços corriqueiros de um caráter trivial, e nem eu ia, movendo-lhe o anzol, propiciar suas costumeiras peripécias de raciocínio, não que me metessem medo as unhas que ela punha nas palavras, eu também, além das 
caras amenas (aqui e ali quem sabe marota), sabia dar ao verbo o reverso das carrancas e das garras, sabia, incisivo como ela, morder certeiro com os dentes das idéias $[. . .]^{26}$.

Em Um copo de cólera, os personagens se mantêm enquanto tem prosseguimento o diálogo entre eles, como estranhas marionetes sustentadas por fios de fala. Por isso é comum que cada assertiva suscite sempre uma réplica do interlocutor, uma resposta germinada sempre da assertiva anterior. O próprio narrador o percebe e declara-o. Quando parece ter conseguido, finalmente, "vencer" o personagem feminino com palavras e atos - entre eles a ameaça de realização sexual, bruscamente interrompida, para a decepção da parceira -, é ele quem cai, literalmente, inerte e mudo, enquanto ela aciona a máquina automotiva, ausentando-se do local da crise e, temporariamente, da narrativa, à qual retornará depois, revigorada nas forças e já elevada - no silêncio e na ausência do outro - à condição de narradora.

É por considerar, no trajeto dos personagens, essas oscilações entre diferentes intensidades de forças que buscamos pensá-lo como uma sequência de cenas ou eventos em que o poder não se coagula num centro emanador, nem distribui em faixas hierárquicas os "poderosos" e os "sem-poder". O poder como se pretende estudar aqui passa por injunções que percorrem todos os tipos de relação, estabelecendo, assim, jogos de poder e não lugares de poder. No pensamento foucaultiano, essa forma de entender o poder segue ao lado de uma visão crítica sobre o discurso da sexualidade na sociedade moderna, desenvolvida em várias obras.

No primeiro volume da História da sexualidade, intitulado A Vontade de saber, Foucault aponta a ilusão da delimitação entre uma "época repressiva" surgida juntamente com a burguesia - o que costumamos chamar de moral vitoriana - e um tempo anterior onde teriam vigorado a livre expressão e um grande arejamento dos usos e dos costumes ligados aos prazeres sexuais. A falsidade dessa 
delimitação temporal acompanha a pseudo-demarcação de limites entre lugares de poder e lugares supostamente isentos dele.

Segundo Foucault, essas oposições hipotéticas didatizariam muito facilmente o que não pode ser assim simplificado. Ele questiona o uso abusivo da hipótese repressiva, aquela que baseia todo trabalho sobre sexo na ideia da repressão, da proibição e da negação supostamente surgidas na era vitoriana. Abre-se espaço, portanto, para interrogar também a suposta liberdade anterior àquela época e alerta-se para o fato de que não basta afirmar, numa rápida leitura de determinados tempo e sociedade, o contrário do que vinha sendo dito antes para se ter chegado à "verdade" sobre o sexo. Suas propostas caminham no sentido de aprofundar - se se quer estudar a história da sexualidade - uma história dos discursos. Na análise foucaultiana, a formulação que sintetizamos no parágrafo seguinte adquire um tom de fábula.

A repressão foi, desde a época clássica, o modo fundamental de ligação entre poder, saber e sexualidade, fazendo parte constitutiva da ordem burguesa, emergindo com o capitalismo, no século XVII, após centenas de anos de arejamento e expressão livre: o uso da força de trabalho - e a necessidade de reprodução dessa mesma força - comparece como objetivo da relação sexual. o que quer que seja estéril, se tenta mostrar-se, é tachado de anormal e paga por isso um alto preço. A sexualidade ilegítima, se não pode ser utilizada na reprodução, nem na produção, que seja usada então para dar lucro, dita a nova economia moral.

Na sequência, todo o texto questiona a validade do princípio de repressão a que se recorre há tanto tempo, toda vez que se pretende falar sobre a presença do sexo nos discursos. Foucault expõe a falsidade da ideia que defende que a repressão é sempre e exatamente aquilo que faz calar, esconder, desaparecer. Diz o pensador que alocando-se, como se fez, a censura da livre expressão sexual à burguesia, fazendo-se coincidir sua história com a do capitalismo, permitiu-se que proliferasse facilmente o discurso simplório que simula uma explicação para a ideia de "sexualidade", ignorando 
inclusive a história do próprio termo e a sua adesão não só ao discurso capitalista e burguês como também aos outros discursos que então surgiam, especialmente o científico - médico, jurídico, pedagógico... Uma explicação que findaria facilmente com a seguinte assertiva: a repressão às sexualidades estéreis se dá pela sua incompatibilidade com as exigências do trabalho: elas não podem produzir operários. Essa formulação, por seu teor simplificador, jamais tornará inteligíveis os movimentos de poder e a sua ligação com a presença do sexo nos mais variados discursos.

Foucault acrescenta que, ao contrário do que se insiste em afirmar nos últimos três séculos, há um aumento gradativo dos discursos sobre sexo a partir do século XVIII. Não só dos discursos ilícitos, de depravação, o que seria um contraponto previsível ao excesso de pudores impostos, mas do próprio discurso autorizado. Não é uma nova mentalidade que justifica a proliferação de discursos sobre sexo, e sim a utilidade que esses discursos passaram a ter para os novos mecanismos de poder que surgiram. O sexo passa a ser não proibido, porém regulamentado. "Entre o Estado e o indivíduo o sexo tornou-se objeto de disputa, e disputa pública; toda uma teia de discursos, de saberes, de análises e de injunções o investiram"27.

Não haveria, no entanto, na própria aceitação fácil e já tão arraigada da hipótese repressiva, um resto daquele antigo pudor de se falar em sexo? - é a pergunta de Foucault. Nisso que imaginamos ser a nossa parcela libertária de discurso para o futuro, na evasão de um tempo e de um espaço onde tudo é supostamente proibido, não estaria incrustada a herança do pensamento cristão? "Há dezenas de anos que nós só falamos de sexo fazendo pose: consciência de desafiar a ordem estabelecida, tom de voz que demonstra saber que se é subversivo, ardor em conjurar o presente e aclamar um futuro para cujo apressamento se pensa contribuir"28. Uma certa promessa de felicidade é perceptível juntamente com o discurso que pensa

27 FOUCAULT, Michel. História da sexualidade. Rio de Janeiro: Graal, 1982. p. 29. v. I. 28 FOUCAULT, 1982, p. 12. 
liberar, para o futuro, as diferentes formas da sexualidade. Não cabe, portanto, pensar os prazeres polimorfos como uma obsessão temática repressiva do espírito vitoriano, porque eles são agora formas instaladas, isoladas e nomeadas por um novo tipo de poder que é dominador sutil dos corpos, de seus prazeres e de seus discursos. 0 ato de colocar o sexo em curso, dando-lhe o direito à palavra, é a nova maneira de organizar as sexualidades comprometedoras da economia produtiva e reprodutiva, e não uma tentativa de bani-las.

Através de tais discursos multiplicaram-se as condenações judiciárias das perversões menores, anexou-se a irregularidade sexual à doença mental; da infância à velhice foi definida uma norma do desenvolvimento sexual e cuidadosamente caracterizados todos os desvios possíveis ${ }^{29}$.

É assim que vão parar a histérica na "casa" de saúde e a prostituta na "casa" de tolerância. Dessa forma, arranjam-se "casas" - isto é, lugares de confinamento - para todos.

Esse ponto do pensamento foucaultiano pede uma análise mais detida. Pode-se explicitar nos seguintes termos cada um desses casos de apropriação do sexo pelos discursos de saber-poder:

1. Um certo afrouxamento das penalidades aplicáveis sobre crimes como o incesto é parte da estratégia que dá lugar a uma rede de "saberes" - como o pedagógico e o médico - que irão trabalhar mais sutil e profundamente, conduzindo desde a infância para o que pode parecer a tentativa de fazer sucumbir a sexualidade infantil, mas que é antes a garantia de que ela permaneça, e cada vez mais discreta, que é exatamente por aí que os tentáculos do poder penetram e podem atingir mais fundo. Como se pode depreender da leitura atenta de Um copo de cólera, a ideia de sexualidade passa a ser uma obsessão (algo como aquilo que Foucault denomina obsessão histórica). Como teria o sexo conquistado o direito a parcelas tão 
grandes do nosso discurso? Provavelmente porque foram pensadas, a ideia de discurso e a de sexualidade, numa simultaneidade histórica.

2. Todo o aparato categorizador das "anomalias sexuais", com sua ampla capacidade de nomear, dando a impressão de que nada ficou fora de sua longa lista de "aberrações" é, na verdade, a nova caça às "sexualidades periféricas”. Se "todas" elas já têm nomes - e tão belos nomes! - a natureza não quererá criar formas novas. As que surgem já nascem enquadradas: "O sodomita era um reincidente, agora o homossexual é uma espécie"30. O poder se liga a um discurso sobre o sexo que é limpo, lúcido, ordenador; que enquadra e esquadrinha - quando não esquarteja - as formas nada previsíveis da sexualidade.

3. Uma rede de perscrutação "curiosa" passa a interrogar minuciosamente o comportamento e a apalpar os corpos, dramatizando, por vezes, cenas conturbadas. Assim o poder vai andar montado no prazer, e vice-versa: poder de escandalizar, no discurso do que leva à clínica a sua "anomalia", ou que a dissimula em frente a um prazer de poder exercer aquela função perscrutadora. Formam-se desse modo "as perpétuas espirais de poder e prazer"31.

4. Extrapolando o pensamento bastante difundido de que no século XIX a sexualidade se reduziu ao casal heterossexual e legítimo, firma-se desde então a existência de grupos de sexualidade múltipla. A escola e a clínica, assim como outras instituições, fixam-se, paradoxalmente, como espaços de relações que não são nem monogâmicas, nem heterossexuais, nem conjugais. Nenhuma barreira, nenhuma interdição às sexualidades múltiplas. Pelo contrário, elas são estimuladas a aparecer nas suas muitas formas, todas já catalogadas. Um poder de penetração persegue-as não para dizimá-las, mas antes para fecundá-las, para ter vida através delas.

Dessa forma, prazer e poder não se excluem, antes se somam. Terapêutico, clínico, pedagógico, todos esses discursos se atrelam ao sexo, constituindo nele, através dele e graças a ele, suas formas e normas: 
A implantação das perversões passa a ser um efeito-instrumento: é através do isolamento, da intensificação e da consolidação das sexualidades periféricas que as relações do poder com o sexo e o prazer se ramificam e multiplicam, medem o corpo e penetram nas condutas. E, nesse avanço dos poderes, fixam-se sexualidades disseminadas, rotuladas segundo uma idade, um lugar, um gosto, um tipo de prática ${ }^{32}$.

Uma espécie de "erotismo discursivo generalizado" passa a se alastrar a partir do século XVIII. E não é fora do poder ou contra ele como alguns pretenderam afirmar - que esses discursos se erguem; é antes com ele e funcionando como veículo para sua atuação, numa prolixidade perversa. Perversa não pelo conteúdo dos discursos que a compõem, mas pela forma disfarçada como representa o poder (e são agora a biologia, a medicina, a política, a pedagogia) utilizando o sexo, trazendo-o ao discurso e estabelecendo assim a rede múltipla de poder e de saber. Veja-se, a exemplo, o texto de Nassar: do mesmo modo que exteriorizam seus anseios e incompatibilidades sexuais, os personagens expõem também o desejo de dominação, pretendendo cada um mostrar-se mais sábio, desfilando um discurso mais contundente e perspicaz que o do outro. A um só tempo lhes preocupam o risco de serem "manipulados" por instâncias do poder instituído e uma possível dominação sexual por parte do parceiro.

Como resultado da adesão do poder ao discurso do prazer (ou vice-versa) estabelece-se um paradoxo: quanto mais se fala, mais se esconde. E a válvula motriz dessa prolixidade que oculta é sempre a consideração de que ainda não se falou o bastante e de que o sexo é um segredo, o que remonta, segundo Foucault, ao pensamento monástico cristão. O sexo é "não o que se mostra obstinadamente mas o que se esconde em toda a parte, presença insidiosa que se corre o risco de se ouvir porque fala em voz tão baixa e muitas vezes disfarçada" ${ }^{33}$. A fala excessiva que proliferou nos últimos séculos é, antes que um sinal de liberação, a prova da utilização do sexo pelos 
mecanismos de poder e de sua retenção pelos discursos oficiais. A prolixidade da colocação do sexo em discurso mobiliza-o, imobilizando-o assim. A sociedade que se desenvolveu no século XVIII leva os discursos sobre sexo muito além de uma economia do prazer, inserindo-os num regime ordenado de saber e transformando o sexo no objeto da grande suspeita.

Em uma leitura do strip-tease parisiense, Roland Barthes enfoca esse mesmo fenômeno paradoxal do esconder mostrando, agora sob o ponto de vista do discurso imagético oferecido nas casas de espetáculo. Barthes fala sobre como aquele tipo de show se baseia numa contradição, dessexualizando a mulher à medida que a despe, como se o erotismo fosse uma delícia terrível, cuja anunciação traz em seu estereótipo a um só tempo o desejo e o seu contrário:

[...] expõe-se o mal para melhor impedir a sua ação e para exorcizá-lo mais eficazmente [...] alguns átomos de erotismo, designados pela própria situação do espetáculo, são na realidade absorvidos num ritual tranqüilizante que neutraliza a carne tão infalivelmente quanto a vacina ou o tabu fixam e contêm a doença ou o 'pecado' $[. . .]^{34}$.

O exotismo, os acessórios, a própria dança têm a função de esconder o corpo. 0 exotismo age pela distância que insinua: leques, luvas, meias e plumas envolvem o corpo num mundo de "objetos mágicos" que o contaminam e perseguem mesmo depois de retirados, deixando-o envolto numa aura de extravagância que em nada lembra o corpo carnal e sua atuação humana. Novamente, quanto mais se expõe, mais se esconde: "a finalidade do strip-tease deixa de ser então expor em plena luz uma profundidade secreta, mas sim, através do despojar de vestes barrocas e artificiais, significar a nudez como veste natural da mulher, o que representa a recuperação final de um estado perfeitamente pudico da carne" 35 .

34 BARTHES, R. Mitologias. Rio de Janeiro: Bertrand Brasil, 1993. p. 93-94. 35 FOUCAULT, 1982, p. 94. 
Retomando a leitura foucaultiana do engendramento sexo-poder nos discursos, percebemos a importância de um certo elemento discursivo: a confissão. Desde que se tem notícia da confissão cristã, o sexo sempre foi seu principal motivo. E é de se notar um interessante mecanismo de mão dupla: por saber, de antemão, da feição de coisa proibida que o sexo tomará no relato confessional, ele se torna, desde bem antes, para aquele que irá confessar, pecaminoso. A lei que irá se impor a ele o torna antecipadamente proibido. A prática sexual, por seu lado, adianta copiosamente o momento da confissão. Um só dispositivo de poder liga teoria e prática, passando o sexo, na confissão, a encenar-se primordialmente na forma discursiva, ainda que íntima e/ou monológica.

\begin{abstract}
Ora, a confissão é um ritual de discurso onde o sujeito que fala coincide com o sujeito do enunciado; é, também, um ritual que se desenrola numa relação de poder, pois não se confessa sem a presença ao menos virtual de um parceiro, que não é simplesmente o interlocutor, mas a instância que requer a confissão, impõe-na, avalia-a e intervém para julgar, punir, perdoar, consolar, reconciliar ${ }^{36}$.
\end{abstract}

Os personagens de Um copo de cólera dão mostra da importância do mecanismo confessional na dupla mão com as relações de prazer. A princípio, todo o texto compreende uma longa confissão de fatos ocorridos em um curto espaço de tempo, o sujeito que "fala" coincidindo com o sujeito do enunciado na primeira pessoa do discurso. Esse aspecto de pessoalidade discursiva encaminha-se para clímax patéticos em cenas como esta, de um mea culpa de teor sócio-patológico:

[...] 'sim, eu, o extraviado, sim, eu, o individualista exacerbado, eu, o inimigo do povo, eu, o irracionalista, eu, o devasso, eu, a epilepsia, o delírio e o desatino, eu, o apaixonado...' [...] '...eu, o pavio convulso, eu, a centelha da desordem, eu, a matéria inflamada, eu, o calor perpétuo, eu, a chama que solapa...' [...] '...eu, o quisto, a chaga, o cancro, a úlcera, o tumor, a ferida, o câncer do corpo, eu, tudo isso sem ironia e muito mais $[. . .]^{37}$. 
A confissão guia assim grande parte da textualidade de Um copo de cólera: as opções políticas, afetivas e sexuais, entre outras, formam a linha confessional do discurso dos protagonistas, especialmente do personagem masculino. Enquanto isso, o parceiro constitui uma ordem suposta, a instância ideal da lei perante a qual o sujeito se mostra e da qual aguarda julgamento. Paradoxalmente, o personagem masculino, que dispensa toda lei e toda ordem, é, ele principalmente, que necessita "confessar-se". No fundo, essa instância legal imaginária se encontra internalizada no sujeito falante, que leva a se chocarem, menos que o seu modo de agir e pensar com o do outro, ações e pensamentos próprios com ações e pensamentos que também são seus, ao que tudo indica longamente reprimidos. o paradoxo é fruído profundamente pelo personagem masculino, que demonstra ter conhecimento da ambivalência do mecanismo confessional de que se vale, entre todas as outras ambivalências que vem experimentando ao longo da narrativa: "se por um lado redime, a confissão por outro também pode liberar: mais do que nunca posso agir como fascista..." ${ }^{38}$.

O trabalho de Foucault sobre o que chama "hipótese repressiva" leva em conta três questões: a) A repressão do sexo seria mesmo uma evidência histórica? b) A mecânica do poder, na nossa sociedade, seria mesmo repressiva? c) o discurso crítico à repressão a estaria combatendo ou participando dela?

Uma análise atenta das relações "poder-saber-prazer"39 pretende não simplesmente anular a hipótese repressiva, e sim observar como o discurso sobre sexo penetra nas condutas mais individuais pelas estratégias de poder instauradas.

Daí, enfim, o fato de o ponto importante não ser determinar se essas produções discursivas e esses efeitos de poder levam a formular a verdade do sexo ou, ao contrário, mentiras destinadas a ocultá-lo, mas revelar a 'vontade de saber' que lhe serve ao mesmo tempo de suporte e instrumento ${ }^{40}$.

38 NASSAR, 1997, p. 67. (Grifo meu).

39 FOUCAULT, 1982, p. 16.

40 Ibidem, p. 17. 
Em Um copo de cólera, a força sexual aparenta ser o móvel secreto para toda ação - física ou verbal - dos personagens. Logo nas primeiras cenas se nota uma certa contenção oral, especialmente do personagem masculino. Nessa parte a escritura funciona muito mais pelo não-dito, pelas lacunas de um diálogo que não acontece, por um vazio cuja força pode ser pressentida pelo leitor. Quando principia a prática sexual propriamente dita, pode-se imaginar que ela compareça como solução para a falha marcada anteriormente na impossibilidade dialógica do casal. Tem início então uma complexa rede de representações, verdadeiro teatro do sexo. Elementos da linguagem passam a ser ligados insistentemente ao corpo, pretendendo solucionar os impasses que são ao mesmo tempo questões sexuais e de poder. No entanto, a tentativa de solução pelo corpo ou pelo gesto é derrotada. Abandonada a cama, é imprescindível retornar ao discurso verbal (um pouco pela insistência da mulher em permanecer na casa). Contudo, um eco da cama permanece. Dos domínios do corpo ressoa a fala da companheira, a reclamação por não ter tido o bastante: “'eu não tive o bastante, mas tive o suficiente' (que era o que ela me dizia sempre)"41. A frase repercute pelo texto, lembrada sempre pelo personagem masculino. Da tentativa de resolução, pelo gesto, do que parecia a princípio sufocado e prestes a explodir, reaparece o discursivo oral na confissão da mulher. Substituem-se assim palavra e gesto, compondo uma alternância de meios expressivos. Tem início a parte do texto denominada "o esporro": um esporro verbal intenciona resolver o que não "resolvera" o esporro orgânico:

[...] eu poderia, isto sim, era topar o desafio, partindo pr'um bate-boca de reconfortante conteúdo coletivo, sabendo que ela, mesmo ansiosa, não desprezava um bom preâmbulo, era só fazer de conta que cairia na sua fisga, beliscando de permeio a isca inteira, mamando seu grão de milho como se lhe mamasse o bico do seio $[. . .]^{42}$.

41 NASSAR, 1997, p. 26.

42 Ibidem, p. 40. (Grifo meu). 
o "prazer" da discussão é diretamente comparado ao prazer sexual de encaminhar-se porumpreâmbulode sensações atéo desfecho orgástico. Manipulando um tanto involuntariamente uma centelha desse poder microfísico, os personagens se entregam aos jogos da fala e do corpo, buscando a ascensão a um lugar pleno de poder que é apenas imaginário, do mesmo modo que a "realização" sexual pelo orgasmo é o descortinar de uma nova busca que se inicia. Assim, o preâmbulo verbal é comparado ao preâmbulo sexual: o narrador conclui, de forma ambivalente, que a parceira, mesmo "ansiosa", não rejeitaria um bom preâmbulo, reconhecendo o prazer com que ela se conduz, igualmente, para o clímax sexual e para o cerne daquela discussão, que é não mais apenas verbal, unindo agora violência e sensualidade:

[...] e vendo nisso quem sabe um recuo, fraqueza, ou sei lá o quê, e associando tudo isso do seu jeito, ela reagiu que nem faísca, e foi metálico, e foi cortante o riso de escárnio 'há-há-há... bicha!' foi a mordida afiada da piranha [...] por isso tornei a dizer 'puta' e tornei a voar a mão [...] mas nada disso me surpreendia, afinal, eu a conhecia bem, pouco importava a qualidade da surra, ela nunca tinha o bastante, só o suficiente $[. . .]^{43}$.

As desavenças entre os personagens são repletas sempre dessa sensualidade metadiscursiva, uma assertiva sorvendo e disseminando o embrião da outra. Tudo - nada - se resolve no âmbito do discurso:

sabia dar ao verbo o reverso das carrancas e das garras, sabia, incisivo como ela, morder certeiro com os dentes das idéias, já que era com esses cacos que se compunham de hábito nossas intrigas [...] mas toda essa agressão discursiva já beirava exaustivamente a monotonia $a^{44}$.

Assim se alternam intensidade e modo das descargas de força, a ejeção verbal sucedendo uma outra, sexual. A alternância de meios 
aparece como a solução para a monotonia da repetição. Observe-se que monotonia é também a característica daquilo que se forma tediosamente de uma só voz, risco excluído do texto de Nassar pela alternância consciência/inconsciência do personagem masculino, pelo calor da ferrenha batalha verbal travada entre os protagonistas e, ao fim, pelo revezamento no papel de narrador.

Em Um copo de cólera, as relações que se mostram vinculadoras das instâncias prazer e poder são reconhecidas pelo próprio narrador, que explicita no diálogo essa promiscuidade: "o achincalhe escondia como sempre um nevoeiro denso de sensualidade, a mesma solicitação queixosa, provocadora"45, "ela mesma se guardando até nos frívolos direitos, esticando prazenteirissimamente a goma das palavras, mascando esta ou aquela como se fosse um elástico ou a porra do pai dela"46.

$\mathrm{O}$ ato de rechaçar a inércia da parceira na cama se acrescenta à acusação de submissão intelectual: "nunca te passou pela cabeça que tudo que você diz, e tudo que você vomita, é tudo coisa que você ouviu de orelhada, que nada do que você dizia você fazia, que você só trepava como donzela, que sem minha alavanca você não é porra nenhuma"47; "(ela insistia no preâmbulo, queria, antes do porrete, que eu lhe acendesse os botões do corpo)"48; "já tinha ido muito longe c'o preâmbulo" ${ }^{49}$. Uma das intenções primeiras do personagem masculino é provar a importância da linguagem do prazer ante qualquer vontade de saber e poder da companheira, aliando a sua "donzelice" à adesão sem resistência ao que chama de "mitos do momento" ${ }^{50}$, especialmente em função da profissão que exerce, ligada, segundo ele, à reprodução de ideias:

\footnotetext{
45 NASSAR, 1997, p. 54.

46 Ibidem, p. 56.

47 Ibidem, p. 48.

48 Ibidem, p. 50.

49 Ibidem, p. 56.

50 NASSAR, 1997, p. 46.
} 
[...] que tanto você insiste em me ensinar, hem jornalistinha de merda? que tanto você insiste em me ensinar se o pouco que você aprendeu da vida foi comigo, comigo ${ }^{51}$ [...] nunca te passou pela cabeça, hem intelecta de merda? nunca te passou pela cabeça que tudo que você diz, e tudo que você vomita, é tudo coisa que você ouviu de orelhada, que nada do que você dizia você fazia, que você só trepava como donzela, que sem minha alavanca você não é porra nenhuma... [... $]^{52}$.

Esquece assim, momentaneamente, o quanto de vontade de poder e o quanto de prazer existem nessa sua fala. Toda tentativa de desautorização do discurso do outro passa necessariamente pelo rebaixamento de sua potência sexual: quando o personagem feminino expõe a incompetência formal do narrador para dar ordens, ele se sente castrado: "e ouvindo o que ela disse eu tremi, não propriamente pela ironia, vazada de resto na técnica primária do sumo apologético, era antes pela obsessiva teima em me castrar, me chamando de "mestre" ${ }^{53}$. Ela lhe tira o sexo junto com a palavra: ele não é "autorizado" a falar, senão por meio da designação irônica de uma mestria impotente; portanto, se vê temporariamente castrado, sem falo e sem fala; ele que vinha se valendo alternadamente de cada uma dessas linguagens: a do corpo e a das palavras.

\footnotetext{
51 Ibidem, p. 44-45.

52 Ibidem, p. 48.

53 Ibidem, p. 45. A utilização da imagem do castrado ligada à figura do sem-poder (ou do sem palavra) não é nova. Em $\mathrm{S} / Z$, Barthes observa o funcionamento dessa estratégia discursiva no Sarrasine, de Balzac, alinhavando esses dois modos: "Mme. de Lanty é a Autoridade original, o Tirano cujo numem silencioso decreta a vida, a morte, a tempestade, a paz; enfim, e sobretudo, Mme. de Lanty mutila o homem (M. de Jaucourt perde seu 'dedo'). Enfim, anunciando Sapho, que tanto amedronta Sarrasine, Mme. de Lanty é a mulher castradora, provida de todos os atributos fantasmáticos do Pai: poder, fascinação, autoridade fundadora, terror, poder de castração" (BARTHES, 1992, p. 68).
} 


\section{REFERÊNCIAS}

BARTHES, Roland. Mitologias. Tradução Rita Buongermino e Pedro de Souza. São Paulo: Bertrand Brasil, 1993.

BARTHES, Roland. S/Z. Tradução Léa Novaes. Rio de Janeiro: Nova Fronteira, 1992.

FOUCAULT, Michel. História da sexualidade. Tradução Maria Thereza da Costa Albuquerque. Rio de Janeiro: Graal, 1980. v. I e II.

FOUCAULT, Michel. Microfísica do poder. Tradução Roberto Machado. Rio de Janeiro: Graal, 1982.

NASSAR, Raduan. Um copo de cólera. São Paulo: Companhia das Letras, 1997. 



\section{O PRAZER DO PODER}

Em Vigiar e punir - uma revisão histórica da violência -, entre outras considerações acerca das mudanças sofridas pelos mecanismos de poder, Michel Foucault mostra como o corpo físico deixou, nos últimos séculos, de ser o objeto principal da penalização, a dor como instrumento de castigo sendo substituída paulatinamente. "O castigo passou de uma arte das sensações insuportáveis a uma economia dos direitos suspensos" ${ }^{54}$. No entanto a carne que vai sendo aos poucos abandonada enquanto alvo direto do castigo passa a objeto de uma rede de relações e coerções muito mais complexas, que se comunicam reforçando a função do corpo enquanto objeto de saber. Uma certa "penalidade do incorporal" avilta a vida sem passar necessariamente pelo ultraje direto do corpo. Assim, modernamente, o conjunto dos métodos punitivos se estende para além do puramente jurídico, não sendo apenas consequência imediata dele, dependendo também de outras formas de poder e de saber, e tendo se disseminado em todas as instituições e formas de relações, sociais ou individuais. Da família à fábrica, da escola ao templo, cada mínimo ato é regido e vigiado; cada desvio é passível de ser sumamente castigado no interior do seu próprio agente, por sua consciência ou pelo seu inconsciente. 
Essa "entrada da alma no palco da justiça penal" ocorre simultaneamente ao desenvolvimento de toda uma "tecnologia política do corpo" 55 que, mais que a capacidade de dominar suas forças físicas, seria o empenho de um conjunto de saberes em controlá-lo numa instrumentação multiforme e heterogênea, porém de resultados coerentes: é a microfísica do poder, em que ele se dá não mais como uma propriedade, mas como uma estratégia; um poder que "se exerce mais que se possui" ${ }^{56}$.

Na História da sexualidade, Foucault observa que foi de um jogo de duplo questionamento - perguntamos ao sexo a sua verdade para ouvir a nossa e dizemos-lhe a sua, decifrando o que dela o sexo nos diz - que se consolidou um "saber do sujeito" 57 . Um saber que se constitui não sobre as formas do que seja um sujeito, mas sobre a sua falta, pelo desvio, com o deslocamento, a lacuna que ele deixa. Foucault explica a dupla constituição da ideia de sujeito: o sujeito de uma ciência é também aquele que foi assujeitado a dar-se como sujeito daquele pensar, acontecimento em nome do qual se investiu, ao longo dos séculos, grande trabalho em todo o Ocidente.

[...] através de círculos cada vez mais fechados, o projeto de uma ciência do sujeito começou a gravitar em torno da questão do sexo. A causalidade no sujeito, o inconsciente do sujeito, a verdade do sujeito no outro que sabe, o saber, nele, daquilo que ele próprio ignora, tudo isso foi possível desenrolar-se no discurso do sexo. Contudo, não devido a alguma propriedade natural inerente ao próprio sexo, mas em função das táticas de poder que são imanentes a tal discurso $[\ldots . .]^{58}$.

O entendimento desse raciocínio sobre questões de poder-saber deve estar ligado a algumas renúncias, entre elas à da utopia do saber livre e desinteressado e à do primado do sujeito livre-pensante; melhor dizendo, à renúncia de todo um modelo de conhecimento aceito durante tantos séculos.

55 Ibidem, p. 26.

56 FOUCAULT, 1987, p. 29.

57 FOUCAULT, 1982, p. 68.

58 Ibidem, p. 68-69. 
Considerando conjuntamente essas ideias, pensamos que seria inócuo procurar no texto de Nassar uma individualidade que colocasse em questão o poder olhando-o com isenção ou manipulando-o do exterior, sem estar envolta nas suas redes. O componente transgressor que se pode querer buscar em Um copo de cólera talvez não se encontre no texto em si, só existindo, ao contrário, pela possibilidade de constante rearticulação de seus elementos - componentes de relações de força no texto - com outros elementos que lhe são exteriores. Nesse contexto, mais importante que buscar afirmar ou negar a hipótese repressiva é talvez observar com minúcia, tanto quanto possível e enquanto pudermos driblar nosso próprio discurso, como ele e o do outro são absorvidos pelos poderes (e os absorvem) na sua rede microfísica e nas malhas em que enreda - e se enreda - com o sexo. A questão talvez possa ser formulada nos seguintes termos: o sexo pode ser, ainda hoje, considerado à revelia das transformações sofridas e imprimidas pelos mecanismos de poder que passaram a atuar? Duas possibilidades opostas são de se esperar de acordo com o emprego que se faça, em análise, do poder, e de acordo com a forma como seja considerado quanto a sua ligação com o desejo: 1. Se o domínio que o poder tem sobre o desejo lhe é apenas exterior (a essa suposta força animal, dionisíaca, libertadora, pura), passa a tomar vulto então a promessa de uma "liberação". 2. Se, pelo contrário, o poder é considerado intrínseco e constitutivo do desejo, resultará que se considerem ambos sempre já enredados. São, de acordo com Michel Foucault, os traços principais de qualquer dessas análises:

1. A relação negativa, que afirma que a única relação possível do poder para com o sexo é dizer-lhe não; para além disso, nada mais pode, o poder, contra o sexo.

2. A instância da regra: o poder seria aquilo que dita a lei para o sexo, reduzindo-o a um regime binário: lícito ou ilícito.

3. O ciclo dainterdição:o poder só poderia, sobre osexo, proibir, almejando o seu desaparecimento, ameaçando-o com o sumiço. 4. A formação de um ciclo de censura: “afirmar que não é 
permitido, impedir que se diga, negar que exista" 59 .

5. A unidade do dispositivo: uma forma geral de poder agiria igualmente em todas as instâncias onde o sexo surgisse. O sujeito, assujeitado, seria sempre aquele que obedece; a submissão seria generalizada diante de uma homogeneidade do poder.

As duas formas de consideração da atuação do poder (a intrínseca e a extrínseca) - igualmente limitativas - reduzem a um efeito geral de obediência e, por se basearem numa visão eminentemente jurídica, pensam um poder sem recursos, cuja única forma de exercício é dizer não. Um poder centrado na ideia de enunciado legal, e ao qual são negadas positividade e produtividade. O narrador de Um copo de cólera articula uma parcela desse poder-saber entranhado no discurso para alcançar objetivos imediatos, inusitados e nada duradouros. Não quer fazer valer a sua palavra, no sentido de que ela possa se tornar definitiva, ser "a última palavra" ou a marca do seu triunfo. Quer antes valer-se dela, pretendendo guiar a situação - e o discurso - sempre até um ponto mais adiante. É assim que age no diálogo com a parceira, incitada pelas assertivas dele a dar continuidade, sempre, ao embate iniciado.

A partir de determinado momento, provocar o(a) parceiro(a) será uma atitude dúbia, ao mesmo tempo um convite sensual e um esboço de dominação: "a vontade de poder misturada à volúpia da submissão" ${ }^{60}$, como define o próprio narrador. A antiga máscara da submissão nada mais é, ali, que o uso de uma outra estratégia de dominação, muito sutil, que é essa vizinha do paradoxo, e que aqui chamaremos o poder-submeter-se. Enquanto o personagem masculino tira proveito das ambivalências presentes em seu diálogo com a mulher, ela se deixa levar pelo jogo: num momento impossível de situar, o personagem feminino passa a encaminhar os fatos todos para o desenlace sexual, enquanto o companheiro segue no seu jogo 
ambivalente. Por um lado, essa suposta "limitação" dela permitirá a ele "submetê-la". Por outro, essa "passividade", seu recolhimento - ao retirar-se do campo de ação dele e assim da narrativa - e o silêncio temporário lhe permitem retornar, desta vez com a ação e a palavra, ou seja, como a nova voz que narra o silêncio e a inércia do outro.

Numa leitura comparativa entre Um copo de cólera e São Bernardo - obra que o próprio Nassar indica como gérmen da sua narrativa -, Sabrina Seldmayer aponta a presença e a ausência do feminino respectivamente como representação da "perícia em manejar o vocabulário" e da "conversão dos narradores em sujeitos amorosos" ou "sujeitos da dúvida":

[...] é a figura feminina que representa a habilidade da tessitura das letras [...]. A perícia em manejar o vocabulário pertence, nessas duas narrativas ficcionais, ao mundo das mulheres [...]. É como se a ausência feminina cravasse um significante ligado à linguagem, como se o episódio da ruptura amorosa convertesse os narradores em sujeitos amorosos. De narradores, que acreditavam na limpidez e transparência das palavras, eles se transformam em sujeitos da dúvida, indagando, depois da partida do objeto amoroso, sobre o que é a linguagem ${ }^{61}$.

Assim, por detrás de uma aparente submissão e da ausência marcante da mulher, o que há é uma outra estratégia de domínio consciente ou não - para a conquista da realização de suas vontades. Bajular o companheiro, paparicá-lo (são os verbos que ele utiliza para descrever as ações dela) tem como objetivo o alcance de efeitos concretos, como a satisfação dos próprios desejos sexuais. E se as metas traçadas e constantemente retraçados pelas forças operantes são diferentes, uma grande parcela de imprevisibilidade percorre todos os tipos de relações. Daquele que pensa estar no domínio para aquele que simula submeter-se existe uma enorme deriva, o espaço habitado por toda inconstância e possibilidade de reversão. o narrador sabe o quanto é falso imaginar que possa guiar os atos 
da companheira e não conduz de forma plenamente voluntária nem mesmo o próprio discurso, mas reconhece a possibilidade de, atécerto ponto, induzir, sem saber ao certo para onde ou por quê, o discurso do outro personagem, provocando-o com sua fala. Movimenta-se assim aquela rede discursiva e de poder que não é fixa e que não os isola em posições estáveis, impulsionando-os, ao contrário, a uma reversibilidade constante de papéis. Mesmo o objetivo que há, se é que se pode falar nisso, é, de imediato, dar curso à cólera: “- atrelado à cólera - eu cavalo só precisava naquele instante dum tiro de partida, era uma resposta, era só de uma resposta que eu precisava"62. Toda e qualquer ofensa que queiram cravar um no outro tem seu fundamento na sexualidade. Desde a imagem angustiante do rombo que se marca no personagem masculino com a invasão das saúvas, passando pelas acusações de "puta"63, "piranha"64, "bicha"65 e "broxa"66 e, principalmente, pela figura que melhor representa a variedade de máscaras possíveis de serem assumidas na busca da reversão sexual mais perceptível: o "travesti". Esta última figura é criada pelo narrador para descrição do personagem feminino; depois, migra para o discurso dela, voltando-se contra ele. Referindo-se à mulher:

[...] você me faz pensar no homem que se veste de mulher no carnaval: o sujeito usa enormes conchas de borracha à guisa de seios, desenha duas rodelas de carmim nas faces, riscos pesados de carvão no lugar das pestanas, avoluma ainda com almofadas as bochechas das nádegas, e sai depois por aí com requebros de cadeira que fazem inveja à mais versátil das cabrochas; com traços tão fortes, o cara consegue ser - embora se traia nos pêlos das pernas e nos pêlos do peito - mais mulher que mulher de verdade [...] os privilegiados como você, fantasiados de povo, me parecem em geral como travesti de carnaval $[. . .]^{67}$.

62 NASSAR, 1997, p. 36.

63 Ibidem, p. 69.

64 Idem.

65 Idem.

66 Ibidem, p. 77.

67 NASSAR, 1997, p. 50. 
A imagem do "travesti de carnaval" não encerra apenas uma dúvida sobre a sexualidade; constitui também uma alegoria do comportamento político: "e tem que isso me leva a pensar que dogmatismo, caricatura e deboche são coisas que muitas vezes andam juntas, e que os privilegiados como você, fantasiados de povo, me parecem em geral como travesti de carnaval"68. A artificialidade do discurso pseudodemocrático da mulher é desmascarada pela comparação com a figura caricata, o simulacro que supera o "original”. Esboça-se então a questão: "mais mulher que mulher de verdade" corresponde a não-mulher? A super-mulher? A homem? Ou será o caso da fruição de um deslocamento entre essas duas instâncias - masculino e feminino -, propiciada pela recorrência aos artifícios da máscara e da fantasia? À imagem da fantasia de carnaval subjaz a consideração do engajamento político como fingimento, simulação artificiosa.

Também é notável o fato de que, aviltado em suas pretensões, o narrador se denomina "puto"69. Inclusive o elemento que lhe tira a tranquilidade são as "malditas saúvas filhas-da-puta"70. Cada cena ou trecho do discurso amarra assim as expressões de insatisfação e a força de reação com os fios tensos da sexualidade: uma ofensa da mulher o atinge "no saco": "eu só sei que essa foi no saco, e não era o meu saco que devia ser atingido"71 e é a "mordida" de uma "piranha": "e foi metálico, e foi cortante o riso de escárnio 'há-há-há... bicha!' foi a mordida afiada da piranha, tentando numa só dentada me capar co'a navalha"72.

É de considerar, entretanto, que faz parte das estratégias do poder manter-se em parte disfarçado. É regra para sua maior tolerabilidade não se mostrar na totalidade. O poder microfísico age, portanto, por tramas sempre até certo ponto ocultas. Afinal, quem suportaria um poder totalmente cínico ou apenas como impositor de censura?

68 Idem.

69 Ibidem, p. 32.

70 Ibidem, p. 31 (Grifo meu).

71 Ibidem, p. 38-39.

72 NASSAR, 1997, p. 69. 
Retorna, portanto, a questão: por que continuar pensando a existência de uma constante histórica repressiva sobre o sexo e o discurso, se o poder já caminha mais além, assenhoreando-se, inclusive, do contrário da repressão, desde o primeiro recurso usado para lhe pôr em discurso, que foi a confissão, se a ordem é fazer falar, se é do maior interesse, por parte do poder, ligar-se aos discursos sobre o sexo nas suas várias formas, a fim de chegar mais longe nas estratégias de domínio, assumindo como novas faces ora a máscara do saber, ora a da moral, os tentáculos da curiosidade científica correndo meticulosamente cada corpo...

Mais, ou menos transgressora, uma das formas de presença do sexo em Um copo de cólera é a sexualização da natureza. As sensações do narrador, sufocado pelo que pode representar o convívio a dois - "dividindo com ela a prisão a que estava sujeito"73 -, incidem na paisagem: "o dia lá fora mal se espreguiçava sob o peso de uma cerração fechada"74. A personificação do dia, do sol e da cerração, especialmente, permite a comparação sexualizante daqueles elementos, já que lhes são doados, por meio dos tropos, corpos: "o sol já estava querendo fazer coisas em cima da cerração, e isso era fácil de ver, era só olhar pra carne porosa e fria da massa que cobria a granja e notar que um brilho pulverizado estava tentando entrar nela"75. Essa pansexualização da natureza assume muitas vezes o caráter de um tratamento metafórico recíproco entre os personagens, pela recorrência a imagens botânicas e zoológicas. Os companheiros de cama são um "cypressus erectus" e uma "trepadeirinha"76. O termo usado pelo narrador para designar a mulher traz a ideia de algo que rasteja e deriva do verbo "trepar" (na acepção popular, fazer sexo). Já o uso do latim supõe distanciamento e artificialidade, criando uma máscara, ali, aparentemente necessária à expressão sexual. Assim se estabelece um código dentro do qual circulam os diálogos mais íntimos do

73 Ibidem, p. 20.

74 Ibidem, p. 19 (Grifo meu).

75 NASSAR 1997, p. 29 (Grifos meus).

76 Ibidem, p. 19. 
casal; um código como devem ser os códigos: fundado no cálculo e no artifício, situação consoante com a efetiva tomada do prazer pelo discurso "autorizado" do saber.

No entanto, essa conjunção da natureza com a sexualidade não serve, em Nassar, à busca de um paraíso perdido, nem nutre qualquer idealização de uma possível naturalidade da relação afetivo-sexual. Se ele a acusa de "mascarar-se", também confessa a própria atuação: "(no chão do picadeiro tinha uma máscara) ${ }^{77 "}$. A personificação do meio natural não faz parte de um empreendimento romântico numa relação simples ou repleta de animalidade. o paraíso natural está de todo perdido e junto com ele o mito da sensualidade do homem rústico, em contato com a natureza. o cuidado devotado a bichos e plantas e a atenção primordialmente dedicada à terra pelo personagem masculino não lhe asseguram uma maior desenvoltura sexual. Pelo contrário, rivalizam ironicamente com a ideia de uma realização sexual plena, expondo a artificialidade e a incompletude de ambos os "labores": o trabalho na terra e a atividade sexual:

a reprimenda múltipla que trazia, fosse pela minha extremada dedicação a bichos e plantas, mas a reprimenda, porventura mais queixosa, por eu não atuar na cama com igual temperatura (quero dizer, com a mesma ardência que empreguei no extermínio das formigas $)^{78}$.

O personagem nassariano, ainda que em contato com a natureza (na chácara, entre bichos e plantas), deixa emergir na fala a artificialidade dessa relação, suplementar a uma outra que é, ela também, apenas ideal: a do convívio social. Ambas as situações se substituem infinitamente. A natureza, que poderia vir a suprir o impossível convívio civilizado, aparece desencantada, não podendo resolver o conflito e nem mesmo manter a pureza de um estatuto. Ela é vista como um suplemento ineficiente para a vida em sociedade. 
Natural e artificial são ambos artifícios a declarar a inadaptabilidade da humana condição, instaurada juntamente com a necessidade artificiosa de seccionar - o eu e o outro, o interior e o exterior, o masculino e o feminino, o natural e o artificial. Em Um copo de cólera, num movimento contrário ao comumente esperado, é o natural que vem suplementar o artificial - a civilização -, e não o oposto.

Como também acontece em Lavoura arcaica, o narrador de Um copo de cólera declara a sua desistência do contato (e do contrato) social: "já foi o tempo em que via a convivência como viável, só exigindo deste bem comum, piedosamente, o meu quinhão, já foi o tempo em que consentia num contrato, deixando muitas coisas de fora sem ceder contudo no que me era vital"79. Aliás, são de certa forma os ecos do desabafo de André, o filho prófugo de Lavoura arcaica, que se podem ouvir em Um copo de cólera.

Em Lavoura arcaica, uma ligação constante e ordenada com a terra relaciona-se à manutenção de André no seio da família, condicionando, ao mesmo tempo, a possibilidade de dar prosseguimento a seus laços afetivo-sexuais com a irmã Ana, num círculo que reverte sempre para o próprio "seio" familiar: o personagem aceita seu pertencimento àquela engrenagem de produção e poder que é a família, desde que tenha garantida como recompensa por seu trabalho na fazenda a continuidade das relações com a irmã. Expondo uma outra faceta imprevisível da relação entre sexo e poder, o sistema que cerceia os atos do narrador André - e o exclui do convívio familiar - automaticamente lhe inspira propostas revolucionárias.

Também em Um copo de cólera os personagens se envolvem numa batalha que é, antes que uma guerra, um teatro: "e foi então que ela, com a mão ainda na maçaneta, deglutindo o grão perfeito do meu chamariz, e desenterrando circunstancialmente uns ares de gente séria (ela sabia representar o seu papel), entrou de novo espontaneamente em cena" ${ }^{\prime 80}$. Ali, a imprevisibilidade é, paradoxalmente, como

79 Ibidem, p. 54.

80 NASSAR, 1997, p. 38. 
que manipulada em seus contornos. A "inconsciência voluntária” da própria posição naquele jogo permite ao narrador se achar perdido num lugar indefinível entre a razão e a paixão, entre ser e representar:

não que eu fosse ingênuo a ponto de lhe exigir coerência, não esperava isso dela, nem arrotava nunca isso de mim, tolos ou safados é que apregoam servir a um único senhor, afinal, bestas paridas de um mesmíssimo ventre imundo, éramos todos portadores das mais escrotas contradições ${ }^{81}$.

A contradição é vista como uma espécie de doença inata do humano, inscrita no ato mesmo de dar à luz. o conceito de reprodução, relacionado de forma inextricável à conjunção macho-fêmea, é grandemente problematizado. O narrador descreve a ejeção virtual a que nos referimos anteriormente por meio de um vocabulário bélico: ao invés de significar criação, a concepção é a própria imagem da destruição, o que ilustra as declarações do narrador de que "não gosta de gente".

[...] e eu poderia ainda meter a língua no buraco da sua orelha, até lhe alcançar o uterozinho lá no fundo do crânio, dizendo fogosamente num certeiro escarro de sangue 'só usa a razão quem nela incorpora suas paixões', tingindo intensamente de vermelho a hortênsia cinza protegida ali, enlouquecendo de vez aquela flor anêmica, fazendo germinar com meu esperma grosso uma nova espécie, essa espécie nova que pouco me importava existisse ou não, era na verdade pra salvar alguns instantes que me rebelava à revelia duma enorme confusão $[. . .]^{82}$.

Nesse momento, o poder do narrador parece "reduzir-se" todo à língua. Não é mais o falo que ejeta; nem mesmo parece se tratar ali da língua enquanto órgão propriamente dito. Todo o seu poder - "eu poderia ainda meter a língua" - é demonstrado - ao menos nessa nova experiência de ejeção - pela linguagem, e em vez de um útero, 
a matriz que lhe interessa "fecundar" é o cérebro. Assim como não lhe importam a criação de uma "nova espécie" ou a conservação da antiga, também não há empenho por parte dele em manter com a parceira laços que perpetuem aquela relação. É sempre para "salvar alguns instantes" que ele realiza cada um dos seus atos: as palavras são soluções imprestáveis; o homem é um ser imprestável. É como se buscasse a explicação para a desgraça humana na própria gênese do ser, inseparáveis o homem e o mal. o fato de provirmos todos de um "ventre imundo" justifica que sejamos "bestas paridas" e que alimentemos as "mais escrotas contradições". Um pessimismo escatológico que desemboca na conclusão: "não amo o próximo, nem sei o que é isso, não gosto de gente, para abreviar minhas preferências"83. Em “O ventre seco", conto publicado em 1984, percebe-se desde o título essa mesma preocupação com a matriz, com a origem do homem, identificada já com a origem do mal. Ali, após revelar à companheira o próprio parentesco com a vizinha desprezada por ela - na verdade mãe do narrador - ele conclui, vendo derrocada mais essa tentativa de convívio, com as mesmas palavras que o narrador de Um copo de cólera: “Sou incapaz mesmo, não gosto de 'gentes maravilhosas', não gosto de gente, para abreviar minhas preferências" ${ }^{\text {. }}$.

Assim, antes que uma repressão que se baseia na negação, na ignorância ou na proibição expressa, nos domínios de Um copo de cólera, a "prisão" a que se "sujeitam" os personagens situa-se entre as instituições que extorquem neles uma representação, passando do espaço da casa, na sua ligação com a concepção de família, ao próprio corpo e aos discursos que essas instituições produzem e reproduzem. E é assim, como representação, que se externam as cenas afetivas. $O$ espaço da cama, a casa e o quintal estabelecem limites dentro do "caos psíquico" onde possam emergir as cenas. Criado o cenário, representam-se os papéis: fascista, puta, bicha, broxa, femeazinha emancipada, órfão grisalho, travesti de carnaval. São máscaras intertrocáveis que têm seu lugar naquele teatro. 
$\mathrm{O}$ auge da individualidade, a desejada intimidade se insinua como instrumento tanto de prazer quanto de estorvo: o abraço da mulher lhe cai como uma corda ao pescoço e ele agora é um meio escravo, um prisioneiro do sexo ou um futuro enforcado que acaba dividindo com ela a sua pena: "ela veio por trás e se enroscou de novo em mim, passando desenvolta a corda dos braços pelo meu pescoço, mas eu com jeito, usando de leve os cotovelos, amassando um pouco seus firmes seios, acabei dividindo com ela a prisão a que estava sujeito" 85 .

Assim é que, ao final, o suposto discurso revolucionário do personagem feminino e a fala radical do personagem masculino exibem uma mesma base moral ordenadora. Ele liga uma suposta inferioridade intelectual dela ao fato de ser mulher. Ela acusa nele a suspeita de uma transgressão inócua que é ao mesmo tempo política e sexual: "você não passa, isto sim, é de um subproduto de paixões obscuras, e toda essa algaravia, obsessivamente desfiada, só serve por sinal pra confirmar velhas suspeitas... aqui com meus botões, aberração moral é sempre cria de aberrações inconfessáveis" ${ }^{86}$. Desse modo, aquela que a princípio sustentava o discurso racional e revolucionário, uma vez provocada passa à máxima recriminação de um comportamento supostamente fora da norma, funcionando como algoz do outro.

Um copo de cólera avulta então como farsa revolucionária cujo alcance estaria justamente nisto: explicitar os mecanismos de poder-saber-prazer que nos constituem e conduzem enquanto humanos. Tem-se, assim, menos a denúncia ingênua do que a teatralização dos afetos submissos e/ou fascistas; menos a revolta do que o revolver violento da banalidade que nos ata e sufoca, num circuito de atos humanos, demasiado humanos.

85 NASSAR, 1997, p. 20 (Grifos meus). 86 Ibidem, p. 63. 


\section{REFERÊNCIAS}

FOUCAULT, Michel. História da sexualidade. Tradução Maria Thereza da Costa Albuquerque. Rio de Janeiro: Graal, 1980. v. I e II.

FOUCAULT, Michel. Microfísica do poder. Tradução Roberto Machado. Rio de Janeiro: Graal, 1982.

FOUCAULT, Michel. Vigiar e punir. Tradução Raquel Ramalhete. Petrópolis: Vozes, 1995.

NASSAR, Raduan. Lavoura arcaica. São Paulo: Companhia das Letras, 1997.

NASSAR, Raduan. Menina a caminho. São Paulo: Companhia das Letras, 1997.

NASSAR, Raduan. Um copo de cólera. São Paulo: Companhia das Letras, 1997.

SELDMAYER, Sabrina. Ao lado esquerdo do pai. Belo Horizonte: Ed. UFMG, 1997. 
CAPÍTULO 3

GUIMARÃES ROSA - VEREDAS DE SAGARANA 



\section{AS RAZÕES DO JOGO EM “DUELO”}

De acordo com o dicionário Aurélio da Língua Portuguesa, a palavra "duelo" designa qualquer tipo de luta ou oposição entre duas partes. Considerando-se essa definição, o conto de Guimarães Rosa intitulado "Duelo", do livro Sagarana, de 1946, desdobra, a partir do título, uma ponta de ironia, já que a narrativa se desenvolverá, até o final, em torno dos primórdios e na preparação sempre frustrada do encontro, sem que as personagens envolvidas se enfrentem para o verdadeiro duelo, indo chegar a termo por meio de outros elementos, estranhos ao combate: as vidas de ambos os contendores.

O enredo daquelas duas vivências (os "duelistas" são Turíbio Todo e Cassiano Gomes) se dá a partir de um ponto de contato que é D. Silivana, a mulher de "grandes olhos bonitos, de cabra tonta" (ROSA, 1884, p. 160) ${ }^{87}$. Turíbio, seu companheiro, é um fabricante de selas destituído do trabalho pela crescente abertura de estradas de ferro e de rodagem na região onde vive, às margens do Rio Borrachudo, no qual ainda pesca, na ocasião em que tem início seu desentendimento com Cassiano. Vejamos como ele é descrito na abertura do texto:

Turíbio Todo, nascido à beira do Borrachudo, era seleiro de profissão, tinha pêlos compridos nas narinas, e chorava sem fazer caretas;

87 A partir desta, as citações que vierem sem referência bibliográfica no corpo do texto foram retiradas do conto "Duelo". Conferir: ROSA, João Guimarães. Sagarana. Rio de Janeiro: Nova Fronteira, 1984. 
palavra por palavra: papudo, vagabundo, vingativo e mau. Mas, no começo desta estória, ele estava com a razão. Aliás, os capiaus afirmam isto assim peremptório, mas bem que no caso havia lugar para atenuantes. Impossível negar a existência do papo; mas papo pequeno, discreto, bilobado e pouco móvel - para cima, para baixo, para os lados - e não o escandaloso "papo de mola, quando anda pede esmola'... Além do mais, ninguém nasce papudo nem arranja papo por gosto: ele resulta das tentativas que o grande percevejo do mato faz para se tornar um animal doméstico nas cafuas de beira-rio, onde há, também cúmplices, camaradas do barbeiro, cinco espécies, mais ou menos, de tatus. E, tão modesto papúsculo, incapaz de tentar o bisturi de um operador, não enfeava o seu proprietário: Turíbio Todo era até simpático: forçado a usar colarinho e gravata, às vezes parecia mesmo elegante. Não tinha, porém, confiança nesses dotes, e daí ser bastante misantropo, e dali ter querido ser seleiro, para poder trabalhar em casa e ser menos visto. (...) Agora, quanto às vibrissas e ao choro sem visagens podia ser que indicassem gosto punitivo e maldade, mas com regra, o quanto necessário, não em excesso ${ }^{88}$.

\title{
Cassiano Gomes, o seu rival, é ex-soldado, afastado do serviço
} militar por ser portador de problemas cardíacos. E é no leito de D. Silivana que seus destinos se cruzam. Vamos à ocasião do encontro:

\begin{abstract}
Mas, por essa altura, Turíbio Todo teria direito de queixar-se tão-só da sua falta de saber-viver; porque avisara à mulher que não viria dormir em casa, tencionando chegar até ao pesqueiro das Quatorze-Cruzes e pernoitar em casa do primo Lucrécio, no Dêcàmão. Mudara de idéia, sem contra-aviso à esposa; bem feito!: veio encontrá-la em pleno (com perdão da palavra, mas é verídica a narrativa) em pleno adultério, no mais doce, dado e descuidoso, dos idílios fraudulentos ${ }^{89}$.
\end{abstract}

Assim, retornando mais cedo da pescaria, Turíbio, um homem de hábitos silenciosos e previsíveis, vê, sem ser visto, sua mulher na cama com o soldado. Vê, silencia e espera o momento certo para a vingança. Alguns dias depois, moralmente apoiado nos códigos 
de honra locais, que pregam a morte do traidor pelas mãos do traído, dirige-se, devidamente armado, à casa de Cassiano Gomes, onde, graças a enorme semelhança, acerta pelas costas o irmão do soldado, com um tiro na nuca. Tem início, então, o duelo irrealizável entre os dois.

Vemos esse "duelo", cujo desfecho jamais se dará, como um complexo jogo em que, perseguindo-se mutuamente a cavalo pelo sertão, cada um lança pistas que o outro irá interpretar. As pistas, rastros e sinais anunciados oralmente a pessoas que passam pelas estradas formam uma longa estratégia mutável e são por vezes falsos, com o intuito de desviar o inimigo; por outras, são verdadeiros e lançados no afã de que o rival, ao tomar conhecimento deles, interprete-os como sendo falsos, num jogo de duplo engodo que terá resultados imprevisíveis, conduzindo o conflito inclusive ao paroxismo de os rivais se cruzarem pelo caminho sem que o percebam:

Mas, nesse depois, deu que um dia Cassiano, surgindo nas Traíras, escutou conversa de que o outro estava na Vista Alegre, aonde viera ter, aquerenciado, com saudades da mulher. Cassiano Gomes tirou suas deduções e tocou riba-rio, sempre beirando o Guaicuí (...) isso enquanto Turíbio Todo, um pouco além norte, fazia uma entrada triunfal em Santo Antônio da Canoa, onde ainda ousou assistir, muito ancho, às festas do Rosário, com teatrinho e leilão. Dançando de raiva, Cassiano fez meia-volta e destorceu caminho, varejando cerradões, batendo trilhos de gado, abrindo o aramado das cercas dos pastos, para cair, sem aviso, no meio dos povoados tranqüilos dos grotões. Mas eram péssimos os voluntários do serviço de informes, e, perto do Saco-dos-Cochos, eles cruzaram, passando a menos de quilômetro um do outro, armados em guerra e esganados por vingança. (...) e, se parassem e pensassem no começo da história, talvez cada um desse muito do seu dinheiro, a fim de escapar dessa engronga, mas coisa isso que não era crível nem possível mais ${ }^{90}$.

90 ROSA, 1984, pp. 163-164. 
No jogo intrincado de perseguição, chega mesmo o momento em que, no afã de enganar Turíbio Todo, Cassiano Gomes engana a si próprio, espalhando aos que encontra pelo caminho uma pista falsa que acaba por se mostrar, no fundo, verdadeira. Depois de muito campear atrás do inimigo, o soldado anuncia que irá se recolher, esperando que assim Turíbio baixe guarda e possa ser pego de surpresa. Ele segue, dizendo àqueles que encontra: “-É... Deste jeito eu não arranjo nada, e fico me acabando à toa... É melhor eu voltar p'ra casa e deixar passar uns tempos, até que ele sossegue e pegue a relaxar..."91. O narrador esclarece: "E Cassiano Gomes estava enganando a si próprio, pois na realidade se sentia de repente cansado, porque um homem é um homem e não é de ferro, e o seu vício cardíaco começara a dar sinal de si" ${ }^{\prime 2}$.

O conjunto dessas estratégias põe em xeque, entre outras, questões como a do valor de verdade. Inexistindo aprioristicamente, ela apenas se perfaz como tal a cada nuance dos movimentos dos duelistas, dependente da intenção que os move, de sua interpretação das pistas deixadas e do ponto de vista que então os guia. No desenrolar desse jogo, a imprevisibilidade dos atos funciona como uma metáfora da vida, enquanto a morte, como única certeza, coroa o seu desfecho vindo de onde menos é esperada.

Num jogo de morte de tal modo imbricado exclui-se já de início uma lógica cartesiana simples, multiplicando-se, por detrás de certa aparência de simplicidade, diversos elementos complicadores. O narrador anuncia essa atmosfera complexa ao substituir a lógica excludente de relações de causa e consequência, praticada pelos capiaus, por uma outra inclusiva, relativa, suplementar e paradoxal:

E, ainda assim, saibamos todos, os capiaus gostam muito de relações de efeito e causa, leviana e dogmaticamente inferidas: Manuel Timborna, por exemplo, há três ou quatro anos vive discutindo com um canoeiro do Rio das Velhas, que afirma que

91 ROSA, 1984, p. 171. 92 ROSA, 1984, p. 171. 
o jacaré-do-papo-amarelo tem o pescoço cor de enxofre por ser mais bravo de que os jacarés outros, ao que contrapõe Timborna que ele só é mais feroz porque tem a base do queixo pintada de limão maduro e açafrão. E é até um trabalho enorme, para a gente sensata, poder dar razão aos dois, quando estão juntos ${ }^{93}$.

Do mesmo modo que é impossível chegar a uma conclusão, no caso dos jacarés, escolhendo uma das assertivas e apontando-a como causa (é bravo porque tem o papo amarelo ou tem o papo amarelo porque é bravo?), também no caso desse outro papudo (Turíbio Todo) a busca de uma razão simples para suas atitudes impossibilita uma solução simples. Ele é "vingativo e mau" (palavras do narrador) porque fora traído? Ou será o oposto? Ou, ainda - pois não é de se desprezar a relação entre "papudos", que o texto oferece: é da existência do papo que lhe vem o mal estar com o entorno ou será o defeito físico antes um sintoma da sua inadaptação? Note-se a descrição do dia da pescaria:

Tinha sido para ele um dia de nhaca: saíra cedo para pescar, e faltara-lhe à beira do córrego o fumo-de-rolo, tendo, em coice e queda, de sofrer com os mosquitos; dera uma topada num toco, danificando os artelhos do pé direito; perdera o anzol grande, engastalhado na coivara; e, voltando para casa, vinha desconsolado, trazendo apenas dois timburés no cambão. Claro que tudo isso, sobrevindo assim em série, estava a exigir desgraça maior, que não faltou ${ }^{94}$.

Nesse começo, antes mesmo de descoberto o envolvimento da companheira com Cassiano, já está instalada a ideia da ação violenta, dirigida, no caso, contra uma totalidade negativa do entorno. Impossível portanto querer achar causa simples para o trajeto vingativo de Turíbio Todo apenas no fato de encontrar Cassiano na cama com D. Silivana. Na busca de uma causa ou origem para os acontecimentos, caminhar-se-á a cada vez um passo atrás, encontrando-se lá, na suposta origem, sempre uma outra origem, que é antes consequência de uma outra. 
A humilhação longa e silenciosamente curtida por ele devido às desvantagens físicas de que é portador, a clareza com que o contato com Cassiano Gomes traz à tona esses e outros defeitos seus, o ócio a que se entrega contra vontade, por ausência de trabalho (a abertura das estradas de rodagem reduzem a demanda de selas, produto do seu trabalho), a má-consciência pela sua suspeitada falta de "saber-viver", no dizer do narrador, e os próprios acontecimentos desagradáveis daquele dia são todos determinantes para o que sucederá, substituindo-se assim numa linha de suplementaridade.

O fato de ser Cassiano e não um outro o traidor de Turíbio serve ainda para enfatizar a condição miserável do seleiro, já que o outro é um militar (o que denota respeito, naquele contexto), um homem bonito e que, afinal, lhe conquista a companheira. Na cena em que Turíbio os avista na cama, a descrição que faz do arsenal de que se cerca para ele a imagem de Cassiano, em comparação com seu parco armamento, que se resume a uma "faquinha de picar fumo e tirar bicho-de-pé" 95 , bem mostra a humilhação a que é submetido. 0 contraste entre as condições sociais dos dois rivais terá grande participação no fomento do ódio já crescente do seleiro pelo ex-militar:

[...] o outro era o Cassiano Gomes, ex-anspeçada do $1^{\circ}$ pelotão da $2^{\mathrm{a}}$ companhia do $5^{\mathrm{o}}$ Batalhão de Infantaria da Força Pública, onde as gentes aprendiam a manejar, por música, o ZB tchecoslovaco e até as metralhadoras pesadas Hotchkiss; e era, portanto, muito homem para lhe acertar um balaço na testa, mesmo estando em sumaríssima indumentária [... $]^{96}$.

Lógica e razão são termos que, por vezes funcionando como sinônimos, têm ali aplicações que fogem diligentemente ao uso comum. A palavra "razão", por exemplo, desliza, no texto, entre diferentes acepções: há a "razão" inicial de Turíbio Todo para sentir-se humilhado e aquela que lhe é agregada socialmente para vingar-se perante 
a ofensa moral sofrida, "razão" que o leva a desviar-se e, num erro, eliminar o irmão do verdadeiro "devedor". Há, em contrapartida, as "razões" que permitem a Cassiano Gomes revidar a morte indevida do irmão. Há também as "razões" de adaptação e luta que justificam, a princípio, tanto a conduta de Turíbio quanto a de Cassiano, e que depõem contra a ideia de uma razão una e mesmo de uma apriorística da razão, que teria de se basear na hipótese de uma lei também una e a priori posta.

Há ainda a tal "razão" das mulheres, que o narrador defende, ironicamente, como devendo primar sobre as demais (note-se ainda que é do contato com D. Silivana que provêm as "razões" da contenda, justificativas para a morte, e que acabarão se mostrando, positivamente, como a "razão" de vida dos adversários). As muitas acepções do termo se misturam assim no texto. A ausência de uma razão apriorística ou transcendental amplia indefinidamente o jogo e seu campo de atuação. Por isso não há uma verdade ou lógica simples a defender ou interpretar. Nada para além das regras do jogo.

Cassiano Gomes, aquele que "primeiramente" é marcado para morrer (e que traz a lembrança da caça, foneticamente, no nome), carrega em si o gérmen da morte, latente na doença que o persegue, e representa, por meio desse traço, toda a categoria humana, incluído aí também o seu algoz ou caçador. Eles seguem no seu jogo letal, como numa roleta russa, adiando e adiantando a morte, fugindo dela e para ela, que cedo ou tarde se mostrará, se não como resultado específico do combate, provindo de algo exógeno a ele, ou ainda de dentro de cada um deles - um dos dois já traz no peito o "vício cardíaco".

Apesar da série de contrastes que a priori delegariam a Turíbio uma condição irremediavelmente inferior com relação a Cassiano, o texto, pela visada altamente reversível que propõe, irá recuperar e transformar uma certa predestinação que muitas vezes as preconceituações fazem supor e mantêm. E é através de um traçado que reconhece o poder como algo que se exerce antes que se possui que o conto de Rosa o faz. 
Esse conceito de poder, desenvolvido pelo pensador francês Michel Foucault, é trazido aqui para o acompanhamento do trajeto dos personagens por considerarmos que as diferentes estratégias por eles desenvolvidas durante o seu "duelo" não cristalizam o poder num centro emanador, nem distribuem em escalas hierárquicas os "poderosos" e os "sem-poder", estabelecendo sim jogos de poder e não lugares de poder, algo que os jogadores bem intuem. Daí que a desconfiança de cada um sobre as pistas deixadas pelo inimigo se amplie até quase passarem paradoxalmente a considerar, de forma consciente, nos atos de defesa, a importância do acaso. Uma verdadeira aporia: as regras do jogo são inescapáveis, ou seja, tudo se dá sempre e somente dentro de uma certa ordem de jogo; no entanto, é tamanha a imprevisibilidade das normas que o governam, criadas sempre no devir do próprio jogo pelos duelistas, que o conjunto de regras tangencia o acaso e mesmo ameaça com a completa dispensabilidade das normas, o que anularia todo o sistema. Somente desse modo se explicam situações como aquela em que os jogadores se buscam até que se encontrem, e então, de forma surpreendente, não se veem.

Ainda que uma grande diferença de situação social separe Turíbio de Cassiano, a partir do momento em que seus destinos se cruzam, arma-se um outro contexto, em que de alguma forma eles se igualam, porque são outras as regras que norteiam agora essa vida dentro da vida, que os une no seu quase-duelo. Pode-se pensar mesmo que o verdadeiro "acerto de contas" já se deu, de forma paradoxal, no erro cometido por Turíbio ao matar o irmão de Cassiano, erro que afinal deixa o soldado livre para a vida, o que nesse caso significa a possibilidade de lutar até a morte, e "de igual para igual". Somente a partir desse engano inaugural é que se inicia de fato a perseguição entre eles, contraditoriamente.

Desde então, Turíbio e Cassiano passam a ser, de certo modo, um personagem do outro, nesse teatro mortal, e a se guiarem por pistas que, de muito voláteis e armadas sobre tantos artifícios, resultam quase tão pouco úteis ao perseguido e ao perseguidor quanto crer no puro acaso ou esperar que o destino se realize. Quando o narrador 
apresenta ao leitor os personagens, cada um dos protagonistas faz do outro uma espécie de criação sua, pelo modo como tece comentários injuriosos acerca do rival junto aos transeuntes nas estradas em que segue à sua procura. Assim o percurso de cada um é traçado, de certo modo, pelo inimigo, nas pistas - verdadeiras ou falsas - que lhe deixa, pistas às quais a criatura tenta, apoiada em suas interpretações, escapar. Por fim, o fato de cada um perseguir, no/do outro, a própria vida, faz com que assuma mais plenamente a função de criador/destruidor.

No desfecho, cada um se revela, enfim, o personagem prófugo do outro, escapando-lhe quase que completamente ao traçado, para viver sua própria vida - e sua morte: Cassiano morre de "causa natural", burlando o desfecho lúdico, e o outro, no meio do jogo - e da narrativa -, parte para São Paulo, indo morrer, ao retornar, pelas mãos de um terceiro. Vejamos o momento em que Turíbio Todo resolve abandonar a luta:

\footnotetext{
Depois, uma turma de sujeitos alegres o interpelou. Iam para o sul, para as lavouras de café. Baianos são-pauleiros. E um deles: Eh, mano veélho! Baâmo pro São Paulo, tchente!... Ganhá munto denheêro... Tchente! Lá tchove denhêro no tchão!... Sentiu saudades da mulher. Mas, era só por uns tempos. Mandava buscá-la, depois. Foi também ${ }^{97}$.
}

Para o leitor que acompanhara até então cada lance da perseguição mútua, é surpreendente a atitude de Turíbio, de partir com uma tropa que encontra no caminho, tendo trocado com seus componentes apenas algumas palavras e deixando pelo meio a contenda com Cassiano. No entanto o fato não é de todo incompreensível, já que, de forma não de todo consciente, o que ele procurava mesmo era uma razão para a vida. Considere-se também que nesse ponto o jogo já vinha se tornando ora monótono, ora arriscado demais, segundo sua própria avaliação, o que poria em perigo seu motivo 
maior até então: a busca paradoxal de uma mudança para a vida, ainda que por meio da morte, sua e/ou de outrem.

Nesse ínterim, e quando o embate entre os dois ainda prosseguia, é que o sistema estabelecido com a perseguição perde verdadeiramente qualquer possível centro: Turíbio segue para São Paulo e Cassiano chega a esquecer por completo o motivo que conduzia seu ódio contra Turíbio, ou seja, a morte do irmão. Apenas quando já bastante debilitado pela doença é que, certo dia, Cassiano Gomes se lembra do falecido:

E ficava calado, recontando os caibros, negros de picumã, e espiando a mexida das aranhas, que jogavam fios-a-prumo para subir e descer. E, pela primeira vez nesses meses, se lembrou do irmão assassinado, realizando ser por causa da morte do mesmo que ele andara em busca de Turíbio Todo ${ }^{98}$.

Turíbio, ao retornar de São Paulo, chega transformado: “Saltou do trem com uma piteira, um relógio de pulseira, boas roupas e uma nova concepção do universo" 99 . Retorna com saudades da mulher, disposto a tudo esquecer e portando mesmo um discurso pacifista. E é aí, no hiato do ódio, razão desarrazoada que insuflava o seu viver, que ele é pego de surpresa e, desarmado, recebe a morte pelas mãos de um capiau franzino em cuja companhia perfizera parte do caminho e a quem já então se afeiçoara bastante. Esse capiau, chamado Vinte-e-Um, se apresenta como compadre do falecido Cassiano Gomes, a quem prometera, como último desejo, vingar a morte do irmão, dando fim ao tal Turíbio Todo.

Na narrativa, Vinte-e-Um é a prova maior do alcance dos lances daquele jogo e da sua perda de centro: arremessada a primeira pedra, torna-se impossível conceber que seu raio de ação permaneça no entorno dos principais jogadores sem contaminar outros elementos, que serão envoltos também nessa rede ao mesmo tempo lúdica e bélica. 
O próprio nome do personagem Vinte-e-Um, que designa também um jogo de cartas, reforça a relação com o jogo e faz retornar a imagem do baralho, que aparece mais de uma vez na narrativa para ilustrar a contenda entre Turíbio e Cassiano:"-Tem tempo... - disse. E continuou a batida, confiado tão só na inspiração do momento, porquanto o baralho fora rebaralhado e agora tinham ambos outros naipes a jogar"100..

Mais uma vez, apenas o devir-estória e a observação aproximada das partes é que pode criar, para os acontecimentos, alguma realidade, dando mostras de que ali é improvável poder se fiar, para agir, em uma razão plena, única ou previamente considerada. Assim como na estória dos jacarés, que abre a narrativa, observados de perto os duelistas, é preciso dar-lhes, a ambos, as suas "razões", agora plurais.

Em vez de reconhecer-se levianamente uma razão que governe a totalidade dos acontecimentos, o que se nota é uma determinada lógica de poder presente na fala de Cassiano Gomes. Diz ele, referindo-se a Turíbio Todo: “- Ele vai como veado acochado, mas volta como cangussu... No meio do caminho a gente topa, e quem puder mais é que vai ter razão..."101. A "razão" que se reconhece então é a da força, a do poder do mais forte no momento do encontro, em pleno caminhar, e aparece como uma nova "razão", suplementar às apresentadas anteriormente. Daí a importância de se acompanhar os lances lúdicos e bélicos em que os personagens se revezam e a alternância de papéis que vem expor a não-fixidez das relações e das razões que as regem, revolvendo valores e verdades comumente aceitos.

Esse entranhamento radical de diferentes posições e pontos de vista lança a necessidade de uma revisão de construções que se baseiam na lógica cartesiana de causa e consequência e de concepções como a de razão, mantenedora, no pensamento ocidental, de toda suposta verdade e, juntamente, de muito engano. O paradoxo e a ambivalência são respostas sempre provisórias aos enigmas incor- 
168 ANDRÉIA DELMASCHIO

porados pelos protagonistas nessa história de vingança e morte, e de luta pelo poder, perante a efemeridade de todos os seres. 


\section{REFERÊNCIAS}

DERRIDA, Jacques. A escritura e a diferença. Tradução Maria Beatriz M. Nizza da Silva. São Paulo: Perspectiva, 1971.

DERRIDA, Jacques. Gramatologia. Tradução Miriam Schnaiderman e Renato Janini Ribeiro. São Paulo: Perspectiva, 1973.

FERREIRA, Aurélio Buarque de Holanda. Novo Dicionário Aurélio de Língua Portuguesa. Rio de Janeiro: Nova Fronteira, 1994.

FOUCAULT, Michel. Microfísica do poder. Tradução Roberto Machado. Rio de Janeiro: Graal, 1982.

FOUCAULT, Michel. Vigiar e punir. Tradução Raquel Ramalhete. Petrópolis: Vozes, 1995.

ROSA, João Guimarães. Sagarana. Rio de Janeiro: Nova Fronteira, 1984. 



\section{"SARAPALHA": O BEM E O MAL DA MALEITA}

Nasceu do mal, a medicina, senão da maleita e se não foi ela, pelo contrário, a provocar e criar peça a peça a doença para dar a si própria uma razão de ser. (Antonin Artaud. O suicidado da sociedade, 1987, p. 23).

O conto "Sarapalha", história de primo Argemiro e primo Ribeiro, tem como cenário um povoado às margens do rio Pará, infestado pela malária ${ }^{102}$ e abandonado por seus antigos habitantes. Os dois primos, há tempos contaminados pela doença, foram os únicos moradores que permaneceram, mesmo após o apelo insistente do médico que atuara no local, para que o deixassem. Quando do fluxo de evasão do lugar, conhecido como "o vau da Sarapalha", também prima Luísa, a mulher de Ribeiro, deixara-o, fugindo na

102 "Infecção que pode incidir no homem e noutros mamíferos, assim como em aves e anfíbios, causada por protozoários do gênero Plasmodium, transmitidos por picadas de mosquitos do gênero Anopheles do qual há cerca de 50 espécies" (FERREIRA, 1994. p. 1259). o Aurélio registra como sinônimos para malária: acréscimo, febre intermitente, febre palustre, helópira, maleita, paludismo, impaludismo, perniciosa, sezão, batedeira, carneirada, tremedeira e treme-treme. Segundo a OMS, a malária é a segunda doença, no mundo, em número de óbitos, perdendo apenas para a AIDS (dados de 2004). Treze anos depois, a OMS aponta as doenças cardiovasculares como primeira causa de morte entre os países com alta concentração de renda; nos países de baixa concentração de renda, a malária perde hoje para doenças de fundo respiratório e para diarreia. O Brasil teve grande diminuição do número de infectados pela malária entre 2000 e 2014, mas segue no desafio de redução dos casos da doença. (Disponível em: <http://agencia.fapesp.br/desafios_para_eliminacao_da_ malaria_no_brasil/24682/. Acesso em: 8 jul. 2017). 
companhia de um boiadeiro que por lá passara. A partir dos diálogos entre o marido abandonado e o primo que coabitava com o casal e que agora permanece em companhia do outro, sabe-se que fora a fuga da mulher o verdadeiro elemento desertificador da vida dos dois homens e que tamanha era a sua importância para eles que, conforme consta do relato de ambos "[...] Se ela chegasse, até a febre sumia..." (ROSA, 1984, p.142) ${ }^{103}$.

Agora, depois de deserto o vau da Sarapalha, Argemiro e Ribeiro ainda "curtem" ali os sintomas diários da sezão ${ }^{104}$ (a febre, o frio que se alterna com o calor, a tontura, o zunido e o delírio), tratando-se com quinino ${ }^{105}$ e auxiliando-se mutuamente nos momentos paroxísmicos da doença, algumas vezes sofrendo o mal e outras saboreando verdadeiramente os seus sintomas. Ocasionalmente é impossível aos enfermos definir se as sensações são resultantes da doença ou da aplicação do medicamento, já que a dosagem excessiva do quinino pode gerar efeitos colaterais similares aos sintomas da febre maleitosa, como zumbido e tontura.

Acompanhando-se de perto os achaques de Argemiro e Ribeiro e os comentários que tecem acerca da vida em Sarapalha, do próprio passado e do drama pessoal vivido - o abandono por parte da mulher -, nota-se que, naquele contexto, curiosamente, o problema principal dos dois homens não será dar um fim à maleita, mas sim à vida, fardo maior a ser carregado. Em determinada circunstância, um dos dois chega a afirmar que "foi bom a sezão ter vindo [...], p'ra isto aqui virar um ermo e a gente poder ficar mais sozinhos..." (p.143) e que, perante a possibilidade da cura, o seu desejo é mais radical: "Não adianta. Está custando muito a chegar a morte... E eu quero é morrer" (p.143). A princípio um grande esforço de relativização é

103 A partir desta, as citações que vierem no corpo do texto sem referência bibliográfica foram retiradas do conto "Sarapalha". Conferir: ROSA, João Guimarães. Sagarana. Rio de Janeiro: Nova Fronteira, 1984.

104 "Sezão" fora o primeiro título dado ao conto por Guimarães Rosa.

1050 quinino é ainda hoje o medicamento mais utilizado no tratamento contra a malária (dado de 2004). Contudo vem sendo substituído aos poucos por medicamentos de maior tolerância pelo organismo humano. 
necessário para que se entenda que positividade pode ser ligada à doença naquele universo. Por outro lado, não se deve esquecer que pensar a saúde como um bem em si e uma pura positividade pressupõe também um esforço de afirmação, condicionado e continuamente solicitado, histórica e culturalmente.

O modo como lemos aqui a malária e seus sintomas se distancia de uma análise clínica dos personagens, portadores, para nós, de uma metáfora, antes que de uma doença. A nossa leitura descerra portanto as cortinas de uma certa metaforização da doença, não contudo no sentido aristotélico tradicional de metáfora como simples substituição de um termo por outro, mas considerando que os nomes de doenças, assim como o conjunto descritivo de agentes e de sintomas são todos, antes de mais, palavras lançadas nos jogos discursivos de nomeação. Desse modo, e a partir de Jacques Derrida, o conceito de metáfora que utilizamos extrapola o sentido meramente substitutivo de um termo por outro, e mesmo o sentido puramente semântico ou linguístico, evidenciando-se como uma rede infinita de inter-relações e trocas que constitui os discursos, como um todo, entre eles o científico, que, no limite, dedica-se a diferençar, classificar e nomear sempre novas doenças, criando assim campos supostamente delimitáveis dentro dos espectros de sintomas, por exemplo.

Assim entendido, no nosso interesse pela utilização dos nomes de doenças na ficção, é fundamental considerar o contexto em que surgem esses nomes, as situações de que se cercam e o que representam na consciência de personagens e de narradores. Temos observado que as diferentes estratégias que constroem os quadros ficcionais em que aparecem enfermidades resultam, muitas vezes, numa inusitada positivação delas, ao contrário do que pretendem alguns estudiosos da presença dos nomes de doenças em discursos que não as tratam de forma puramente denotativa, pureza difícil de alcançar mesmo nos discursos ditos científicos. Dentre os estudiosos digamos "anti-metafóricos" destaca-se a grande pesquisadora e ativista estadunidense Susan Sontag. 
Em seu estudo sobre a (des)metaforização da doença, em que propõe que se evite utilizar como metáforas termos como câncer, por exemplo, a escritora norte-americana afirma que o conceito de doença nunca é inocente e defende que é um desserviço que se presta ao enfermo citar-lhe o nome da enfermidade de modo a indicar uma determinada situação política, por exemplo. A sua luta contra o uso metafórico das enfermidades justifica-se, ao mesmo tempo em que é enfraquecida, pela experiência de um câncer, na ocasião da escrita de A doença como metáfora. Numa publicação posterior, intitulada Aids e suas metáforas, a escritora reafirma sua posição contra a metaforização da doença, destacando então o fato de que o câncer passou a ser bem menos estigmatizado com o surgimento da AIDS. O que ela não percebe, entretanto, é o paradoxo que sobrevive na própria substituição que aponta: em busca de uma resposta à questão da utilização dos nomes de doenças nos diversos discursos, não pode prescindir, ela mesma, da recorrência a eles, numa demonstração de que, às vezes, contestar é também endossar.

A partir dessas considerações nos perguntamos se será possível, numa tentativa de desmetaforização da doença, refrear o movimento discursivo de nomeação, ele que se mascara sempre e cada vez mais diferentemente. Parece algo tão improvável quanto querer eliminar as doenças, hoje, ignorando todos os fatores exógenos ligados a sua existência, como se uma enfermidade não fosse delineada, também, por uma construção discursiva, como se existisse "o próprio mal", independente da interpretação que se faz dele. Desse modo, evitar que os nomes de doenças estejam presentes em mais um campo discursivo - por exemplo o ficcional - seria acatar a rigidez com que se tentam fixar em outros discursos - especialmente o médico-científico, como se esses representassem uma verdade exclusiva.

No caso de "Sarapalha", há muitas questões a serem levadas em conta para que se entenda a relação dos personagens com a doença, entre elas: a ênfase dada à inércia enquanto sintoma, a estetização do ataque, a feminização do inseto transmissor, a flutuação entre 
consciente e inconsciente, o abalo da oposição simples entre saúde e doença, a confusão entre efeito colateral e sintoma e o paradoxal desejo de morte.

Iniciemos pela observação do estado inerte dos personagens, questão à qual as demais irão sendo alinhavadas aos poucos. A inércia que faz com que os protagonistas permaneçam presos à localidade condenada, onde continuam sendo picados pelo mosquito transmissor da malária, surge como mais que um simples mote para o desenvolvimento do enredo. A sua ocorrência na narrativa também não deve apenas ser entendida como sinal da concordância de Guimarães Rosa com certos preconceitos acerca da preguiça do caboclo, como sugerem alguns estudos.

Por que, enquanto uns morrem aos primeiros ataques da malária e outros deixam o vau da Sarapalha, os primos Argemiro e Ribeiro permanecem, unidos na sua miséria e doença? Aos poucos se percebe que a verdadeira causa do estado geral dos dois é antes o abandono por parte de Luísa que a doença propriamente dita. 0 acovardamento diante dos fatos - sensação que os prende a Sarapalha e que os impede de ir em busca da mulher - é ele mesmo justificado pela existência da maleita:

Na hora, quando a Maria Preta me deu o recado dela se despedindo, mandando dizer que ia acompanhar o outro porque gostava era dele e não gostava mais de mim, eu fiquei meio doido... Mas não quis ir atrás, não... Tive vergonha dos outros... Todo-o-mundo já sabia... E, ela, eu tinha obrigação de matar também, e sabia que a coragem p'ra isso havia de faltar... Também, nesse tempo, a gente já estava amaleitados, pois não estava?... Foi bom a sezão ter vindo, Primo Argemiro, p'ra isto aqui virar um ermo e a gente poder ficar mais sozinhos... (p. 143)

É como se a doença - e especialmente a imobilidade resultante do conjunto dos sintomas - fosse uma ampla metáfora das faltas, falhas, ausências e impossibilidades que pontuam a vida dos dois homens, além de uma justificativa para tudo o que não foram capazes de realizar e, especialmente, para o que não vierem a fazer 
a partir de então. Meio caminho para a morte, a doença chega como solução para aqueles que já não se sentem no domínio da vida.

Se considerarmos a forma como é descrito no conto o ato de contágio da doença, ou seja, por meio de um ataque sedutor, envolto em música inebriante (o zunido produzido pelo mosquito anofelino) e exclusivamente realizado pela fêmea - dados baseados em relatos científicos -, perceberemos a "feminização" da doença e do mal; por extensão, umacerta demonização do feminino. Deacordo comestudos pormenorizados do mosquito transmissor, o macho do anofelino, ao nascer, encaminha-se à floresta, onde por toda a vida se alimentará do néctar de flores, enquanto a fêmea irá em busca do sangue dos que dormem, num zumbido encantatório, violino anofelino que Rosa introduz em seu conto, em meio à orquestra hipnotizante de doces e terríveis anjos fêmeas que rondam os ouvidos dos homens.

E se com a chegada da doença parte da população de Sarapalha evade, seguindo conselhos médicos, os primos permanecem. A cada dia vão perdendo a força de reação e a capacidade de evadir. A literatura médica relata um fenômeno que envolve os que vivem em zona de contágio frequente: quanto mais vezes contrai a doença, tanto mais resistente a ela se torna a pessoa, o que aponta para um paradoxo em que quanto mais doença, menos doente. Resistência de que resulta (e que resulta de) uma rede ambivalente de sintomas, tanto bons quanto ruins: o estado semi-consciente característico dos delírios febris alivia a consciência da dificuldade daquela mesma situação; os calafrios gerados pela febre aplacam-lhe (à febre) o próprio calor: é a cura nascendo da doença. Por outro lado, a doença consolida a necessidade da inércia, justificando-a, o que, poder-se-ia dizer, faz surgir a doença como sintoma do sintoma.

Essa inação, que para o médico que por lá passara é motivo de revolta, amplia-se, no universo de Argemiro e Ribeiro, criando uma indecidibilidade entre bem e mal. O movimento indecidível da doença é expresso na comparação feita durante um delírio pelo próprio médico que vivera no local, tentando erradicar a febre, e liga-a, indubitavelmente, a feminino. Nas suas palavras, "a maleita 
era uma mulher de muita lindeza, que morava de-noite nesses brejos, e na hora da gente tremer era quem vinha... e ninguém não via que era ela quem estava mesmo beijando a gente..." (p. 148). Além de designar a estranha fruição prazerosa dos primeiros sintomas da doença, que no entanto trará depois terrível paroxismo, a frase, metaforicamente, refere o pensamento corrente ainda hoje, em determinados contextos, de que o contato com a malária, como também com a mulher - incluída aí a de Argemiro -, passa por um primeiro momento atrativo, levando depois, fatalmente, a grandes sofrimentos e, algumas vezes, à inanição e à morte.

Por esse traço os personagens de "Sarapalha" assemelham-se àqueles a que Roberto Corrêa dos Santos se refere em Modos de saber, modos de adoecer, surgidos em textos do século XIX e nos quais "os fantasmas subjetivos avolumam-se, excedem-se em qualidades e expõem-se de súbito nas fragilizações corporais" (SANTOS, 1999, p.19). Adoecidos com a partida de Luísa, Argemiro e Ribeiro fazem pensar se sua doença seria uma doença "real" ou se os sintomas que os acometem não seriam antes as marcas da solidão, do abandono e da ausência de perspectiva, sendo o conjunto sintomático da maleita uma metáfora das faltas que constituem o seu viver.

Diante do prazer relembrado (preso ao tempo passado, vivido na presença da mulher), os dois homens se entregam a uma desistência do presente e da saúde. "A carga de dor provocada pela cena afetiva impõe recusa à vida. A defesa e seus mecanismos são de natureza reativa: para não sofrer do afeto, sofre-se de fato do corpo - este o modo que a memória escolhe para descarregar. A doença, e em suma a morte, revelam-se um desprazer menor a substituir o desprazer maior, a dificuldade afetiva" (SANTOS, 1999, p. 20). É como se, assim como a exposição contínua à malária lhe cria resistência, essa dor, surgida do convívio passado com a mulher só pudesse ser sanada pelo próprio convívio, ainda que apenas rememorado - ou por isso mesmo. Novamente, do próprio mal, a sua cura.

Considerando-se, enfim, em conjunto, as circunstâncias que envolvem a vida dos dois enfermos, a febre passa a ser um prenúncio 
de positividade: além de solicitar solidariedade, ela preenche com delírios francamente alucinatórios a vivência tediosa e sem saída, sintoma que é experimentado com delícia pelos primos. Diante do mal que a própria vida mostra ser, a morte e seu agente, a doença, são, por vezes, considerados um bem: “- Quer o remédio, Primo? Não vou tomar mais... Não adianta. Está custando muito a chegar a morte... E eu quero é morrer" (p. 143). Curiosamente, do remédio se espera não mais a cura, e sim a morte, a doença indicando o caminho "natural" para o fim tão esperado.

Dando provas da grande instabilidade dos conceitos com que se tenta delimitar bem e mal, vida e morte, a vida surge como elemento por vezes renegado, fato que é desde sempre incontestavelmente paradoxal: em vida desejar a morte, como se fosse mesmo possível o desejo desta sem aquela: sendo que a vida é a priori necessária para que se deseje a morte, o que dá à vida um status de prioridade que contudo só faz sentido em contraste com a morte e, na direção desta, a vida portanto existe para, de algum modo, desejá-la e, por fim, misturar-se a ela.

Em outro lance de reversão que deve ser destacado, o ataque do mosquito transmissor surge, paradoxalmente, como uma espécie de "antídoto" (alexiphármakon) para o "veneno" (phármakon) que seria o quinino. Assim, à declaração de primo Ribeiro de que o mosquito zune em seus ouvidos, Argemiro acrescenta: “- É a zoeira do quinino... Você está tomando demais...” (p. 135). Às reclamações de Ribeiro de dor nos olhos e confusão visual, o outro esclarece: “-É do remédio..." (p. 137). É o "veneno" se aplicando contra o "andídoto", a doença e o remédio aproximando-se pela coincidência entre efeitos e sintomas.

Como se vê, é numa espiral complexa que se desenvolve a atmosfera deste conto, aquele de que Rosa dizia menos gostar. A malária, que a princípio parece ser o leitmotiv da narrativa, ao final aparece como solução, antes que como problema.

Para além de sua utilização pretensamente isenta de conotações metafóricas ou simbólicas, os nomes de doenças, sintomas e 
agentes, como quaisquer outras categorias de palavras, tendem a migrar, sempre, daqueles discursos que os querem somente a eles subscritos. A utilização "metafórica" que perseguimos no conto de Rosa inaugura assim diferentes possibilidades de leitura daquele contexto em que aparece a maleita, um dos quais buscamos entender como a positivação de elementos considerados negativos quando postos em oposição não problematizada com o seu par. O texto de Rosa estabelece, portanto, além de uma surpreendente virada entre os conceitos de saúde e doença, de remédio e doença, uma série de reversões entre bem e mal, consciência e inconsciência, solução e problema, vida e morte. 


\section{REFERÊNCIAS}

ARTAUD, Antonin. Van Gogh: o suicidado da sociedade. Tradução Aníbal Fernandes. Lisboa: Livreiros Editores e Distribuidores Ltda, 1987. 54 p.

DERRIDA, Jacques. A farmácia de Platão. Tradução Rogério da Costa. São Paulo: Iluminuras, 1991. 126 p.

FERREIRA, Aurélio Buarque de Holanda. Novo Dicionário Aurélio de Língua Portuguesa. Rio de Janeiro: Nova Fronteira, 1994. 2128 p.

PLATÃO. Fedro. Tradução Pinharanda Gomes. Lisboa: Guimarães e Cia Editores, 1981. 159 p.

ROSA, João Guimarães. Sagarana. Rio de Janeiro: Nova Fronteira, 1984. $386 \mathrm{p}$.

SANTOS, Roberto Corrêa dos. Modos de saber, modos de adoecer. Belo Horizonte: Ed. UFMG, 1999. 170 p.

SILVEIRA, James Rudy. 0 agente transmissor da malária. Disponível em: <http://www.geocities.com/entomologia2000/malária.thml>. Acesso em: 20 ago. de 2004.

SONTAG, Susan. A doença como metáfora. Tradução Márcio Ramalho. Rio de Janeiro: Graal, 1984. 108 p.

SONTAG, Susan. Aids e suas metáforas. Tradução Paulo Henriques Britto. São Paulo: Companhia das Letras, 1989. 111 p. 


\section{"SÃO MARCOS": A MIMESE COMO PRODUÇÃO DA DIFERENÇA}

O conto "São Marcos", segundo o próprio autor "a peça mais trabalhada do livro [Sagarana]" (ROSA, 1984, p. 11), abre-se a várias possibilidades de leitura, por constituir um percurso altamente simbólico. o caminho que escolhemos passa pelo estudo do texto ficcional como jogo. Serão observados aspectos lúdicos nos níveis do enunciado e da enunciação.

Também consideramos a questão da "mimese como não imitatio", porque se supusermos e desejarmos aceitar o texto literário como jogo, deveremos antes estar cientes da possibilidade que surge, com a narrativa moderna, de pôr em cheque toda a estética tradicional da representação.

O conceito proposto na Antiguidade por Platão e retomado por Aristóteles tem sido interpretado, ao longo do tempo, como a condição que tem a arte de reproduzir o real, funcionando como uma espécie de cópia dele. Para muitos esta noção advém de um erro de interpretação do conceito, não desenvolvido por Aristóteles em sua Poética.

A expressão citada acima, de Luiz Costa Lima, propõe uma revisão do termo, uma "mudança radical quanto ao que dela fizeram as poéticas clássicas. A mimese, ao contrário de sua falsa tradução, imitatio, não é produção da semelhança, mas produção da diferença" (COSTA LIMA, 1980, p. 361). Interessa, especialmente, em seu estudo, 
que esta produção da diferença será abordada tanto do ponto de vista do produtor quanto do receptor, devidamente consideradas as possibilidades de que ambos ativem seu imaginário, ou seja, aceitem as regras do jogo ficcional.

Nesse sentido, a possibilidade de leitura que se enfatiza aqui é a do texto como local de criação e destruição da ilusão referencial, como a concebe Michel Rifattere em ensaio homônimo: "A existência de uma realidade não-verbal fora do universo das palavras é inegável. Todavia, a crença ingênua num contato ou relação direta entre palavras e referentes é uma ilusão" (BARTHES, 1984, p.100).

Ali, esboçará a explicação do que chama de uma "mitologia do real", ou seja, o apego dos falantes à ideia de que as palavras estão ligadas diretamente à realidade, relação que naturalmente não há, existindo apenas a partir de uma convencionalidade grupal e devendo ser evitada pelo crítico, que se encarregará de demonstrar que estratégias estão envolvidas nesse processo ilusório.

Ludus ou illudere? A ludicidade que se pretende estudar será o resultado tanto do pensamento mágico (primitivo ou religioso) como do que chamaremos de contrato lúdico, conjunto de estratégias capazes de possibilitar a vivência do próprio texto literário como jogo. Os dois temas se intersecionam do ponto de vista da representação simbólica, ou da ilusão que a produz e envolve. Por meio da análise de ambos enquanto emanações do universo criado em "São Marcos", almeja-se ampliar o entendimento dessas duas formas icônicas como terrenos propícios à interação dos seres humanos em sociedade.

Neste estudo, utilizaremos indistintamente os termos pensamento mágico e pensamento religioso, não explorando assim a dicotomia vigente até o início deste século entre estudiosos que tentaram definir-lhes as especificidades, veiculada ainda atualmente pelo senso-comum, por nos parecer que se baseia antes em preconceitos que em ocorrências realmente diferenciadoras de categorias ${ }^{106}$. Propomos

106 Para a antropologia clássica, ainda no início deste século, a crença na magia representava a ilusão de poder intervir na ordem natural do mundo. Frazer a definira como uma "falsa ciência" e Lévy-Bruhl como prova da existência de uma "mentalidade primitiva". cf. 
aqui um entendimento da magia ou do pensamento religioso como mais um sistema simbólico entre todos os que constituem a vida social, e nos interessamos particularmente por descobrir em que pontos ele pode ser comparado ao jogo criado no texto ficcional.

Acrescentamos que, assim como todo ato simbólico é social, também o ritual mágico será o resultado de um empreendimento comunitário, mesmo que de maneira indireta. Por detrás das formas específicas de uma dada representação, encontramos a organização social sua geradora. Pensa-se justificar, desta forma, a necessária, ainda que rápida, incursão pela notação das relações de poder no texto.

Simultaneamente, dois planos serão analisados aqui: um plano interno à narrativa, e um outro externo a ela. Naquele, buscam-se os elementos que constituem o pensamento mágico propriamente dito e, ocasionalmente, as relações de poder, baseando-se na análise da construção dos personagens, dos acontecimentos etc.; neste, envereda-se pela observação da maneira como se dão no texto as condições de auto-referencialidade necessárias ao estabelecimento do ato de leitura - e de escritura - como jogo.

Estaremos ao final buscando entender como a aceitação, seja do jogo ficcional, seja do pensamento religioso, constituem formas possíveis de vivenciar o real e, por que não dizer, de atuar sobre ele.

\section{“GUENTA O RELANCE”, LEITOR!}

Na Divina Comédia, ao adentrar os portais infernais, um aterrado Dante se depara com a inscrição terrível: "Renunciai às esperanças, vós que entrais" (ALIGHIERI, 1979, p. 31). O sentido da inscrição não é apreendido de imediato pelo poeta e ele é convidado por seu guia, Virgílio, a encarar com destemor a experiência por que irá passar.

As palavras inscritas ali estão imbuídas do aspecto performativo - aquele em que se cumpre ao mesmo tempo em que se enuncia 
-, especialmente porque são a palavra divina, o verbo ontológico do qual, para o espírito religioso, é impossível fugir. Assim se estabelece um rito de passagem; é marcado o abandono de um território para a incursão em um outro, cujas leis específicas devem ser obedecidas por aquele que lhe penetra.

No plano de construção interno de "São Marcos", semelhantemente, dar-se-á, para o personagem principal, uma certa alternância de planos, ocorrida quando aquele se descobre de repente tocado pelo místico; no plano externo tem-se uma cumplicidade criativa, uma interação lúdica que pode ligar texto, autor e leitor.

O primeiro passo para a entrada num universo onde predomina o lúdico é dado já na epígrafe: “Eu vi um homem lá na grimpa do coqueiro, ai-ai,/ não era homem, era um coco bem maduro, oi-oi./ Não era coco, era a creca de um macaco, ai-ai,/ não era a creca, era o macaco todo inteiro, oi-oi"107. Ali, na "cantiga de espantar males", nota-se que importa menos o que realmente se vê no coqueiro (perceba-se a presença deste verbo no primeiro verso e sua negação no restante da cantiga) do que o ato lúdico de entoar aquele canto. Nele, o motivo inicial é incansavelmente substituído, porque tanto o objetivo da cantiga como o objeto da visão parecem ser, para o mundo concreto, paradoxalmente, nenhum. Sua função é ocupar a mente, desviando-a do caminho do medo, por onde quer enveredar.

Anuncia-se, assim, a gênese de um sistema descompromissado com qualquer verdade ou ideia totalizante ou totalitária, que é o texto rosiano. Distante de pretender reproduzir uma realidade, ele tem sua existência ligada às projeções possíveis do imaginário daqueles que o vivenciam.

O jogo, sendo um esquema de alternância que esconde, expondo, é a situação que se estabelece para impor a dúvida; para, em última instância, obrigar à opção. Vejamos como o narrador de "São Marcos" joga com o leitor.

107 A partir desta, todas as citações que vierem sem indicação de nota foram retiradas de "São Marcos". Os grifos são meus. 
A princípio, desdobra-se em mais de um personagem. Nas primeiras páginas, ele é aquele que

entrava no mato, e lá passava o dia inteiro, só para ver uma mudinha de cambuí a medrar da terra de-dentro de um camboatã [por enquanto atente-se para a presença do verbo ver]... para saber se o meu xarájoão-de-barro fecharia mesmo a sua olaria, guardando o descanso domingueiro...

O nome sugerido coincide com o nome do próprio autor, o que causa no leitor um certo desconforto ou surpresa, por imaginar-se, repentinamente, diante daquele, e como que traído na sua empreitada pelo mundo da ficção.

Logo a seguir, porém, ouvindo na mata um grito de alerta:"‘Güenta o relance, Izé!...”, o personagem narrador surpreende com a afirmação: "Estremeci e me voltei, porque, nesta estória, eu também me chamarei José".

E é assim que o jogo de repente se desfaz, ou melhor, se inicia, a palavra estória desvendando o aspecto ficcional do texto e o personagem mostrando como é possível ali mascarar-se e desmascarar-se. Esse desvendamento é o que interpretamos aqui como a negação de uma possível ilusão referencial; estabelece o início do verdadeiro jogo ficcional, lança as suas regras. É o bilhete de entrada para o leitor, que será seguido durante todo o texto pela lembrança constante daquela voz que não se sabe ao certo de onde vem: "- "Güenta o relance [...]".

Assim como se anuncia, no poema dantesco, à porta do mundo dos mortos, a morte da esperança, emana de "São Marcos" o aviso: Vós que entrais, perdei toda a ilusão $0^{108}$.

Daqui por diante apontamos a possibilidade de ler-se todo o itinerário do personagem pela floresta como alegoria do caminhar do leitor pelo terreno da escritura.

108 Entenda-se, aqui, a ilusão referencial, no sentido com que a utiliza Michel Rifattere e como fora introduzida anteriormente. 
Durante a leitura do texto, depara-se com o constante convite a um necessário abandono do referencial, convite que se reitera a cada elemento que comparece: ora são as belas descrições panteístas da floresta e a musicalidade utilizada, ora a própria insinuação de toda uma historiografia literária... todos têm a mesma função: conduzir o leitor por uma atmosfera que nada mais é que aquele novo universo criado - mais denso, por vezes rarefeito: o literário. Se abdicar da necessidade primária de identificação, o leitor poderá fruir melhor este universo que adentra, podendo, através dele, inclusive, retomar diferentemente o real circunstancial.

O personagem central, aquele que costuma se embrenhar na mata para presenciar fenômenos naturais, estando um dia a apreciar aqueles acontecimentos, de todo ligados às próprias sensações, especialmente à visão, tem de repente totalmente tolhida a percepção visual. Indo mais adiante, descobrirá que o feiticeiro de quem tripudiara longamente havia construído um vodu seu, cujos olhos teria vendado.

Ao mesmo tempo em que externamente se desdobra em mais de um personagem, o narrador é também, no plano interno da narrativa, um personagem na mão do feiticeiro, que o recriou na imagem do boneco de pano. Interpenetram-se, assim, dois planos, através de duas formas de representação: a religiosa e a literária.

$\mathrm{Na}$ verdade, tanto a criação literária quanto o ritual mágico constituem-se do simbólico, e diria mesmo que seria esta a sua forma de atuação sobre o real, do qual ambos derivam e retiram, por fim, sua razão de ser. Nas sociedades ditas primitivas, um feiticeiro ou líder espiritual seria não um inventor de ritos, mas aquele que condensa e utiliza os poderes que a sociedade lhe empresta.

o que queremos apontar é que o texto também estará expondo, ainda que indiretamente, toda uma engrenagem de poder, e demonstrando que ela fatalmente se arma, a princípio, sobre o elemento simbólico, sobre a própria linguagem. Afinal, todo o enredo de "São Marcos", que, se resumido e destituído de poesia, resulta na cegueira da qual é acometido o personagem Izé, é impulsionado, 
ou pelo menos está diretamente ligado à situação social daquele no seu meio, em relação aos demais: ele é excêntrico, possui hábitos pouco comuns ao ambiente em que vive, conserva criados, é irônico, especialmente com os humildes, é cético em relação às formas de religiosidade locais, assumindo-se indiretamente como panteísta, possui vocabulário rico e conhecimentos gerais que o distinguem da maioria, dirigindo inclusive algumas trovas ao seu interlocutor no bambual e ensaiando uma poética própria: "Sim, que, à parte o sentido prisco, valia o ileso gume do vocábulo pouco visto e menos ainda ouvido, raramente usado, melhor fora se jamais usado [...]".

Dessa suposta superioridade é que se originam, logicamente, alguns traços comportamentais: ele ignora os avisos de Sá Nhá Rita Preta, debocha de Mangolô, ironiza Aurísio Manquitola e o faria com quantos mais lhe cruzassem o caminho.

Apenas após vivida toda sua experiência de treva em meio à floresta, ele estará apto a reconhecer:

E só hoje é que realizo que eu era assim o pior-de-todos, mesmo do que o Saturnino Pingapinga, capiau que - a história é antiga - errou de porta, dormiu com uma mulher que não era a sua, e se curou de um mal-de-engasgo, trazendo a receita médica no bolso, só porque não tinha dinheiro para a mandar aviar.

A sua pretensa distinção com relação aos demais pode finalmente ser relativizada. Devem ser observados os termos que, não obstante, ainda utiliza na descrição de Saturnino Pingapinga; afinal, ele se reconhece sendo pior que um capiau que não tinha dinheiro. Está demarcada sua posição inicial com relação àquele: o outro era ignorante, crente ou ingênuo, porque curou-se guardando uma receita médica no bolso, como se fosse uma poção mágica, postura que o narrador indiretamente condiciona ao seu status de "sem dinheiro", mas que foi também a sua própria forma de agir, pois ele mesmo trazia na carteira uma mandinga protetora e, quando perdido na mata, recorre sem titubear à oração proibida. 
Diante do inexplicável, reformulam-se valores e verdades. Assim como os demais, o personagem Izé também nutria o sentimento religioso; apenas a oportunidade o expõe.

Postas as regras do jogo, temos um personagem perdido cego numa mata e um leitor em meio às malhas do texto. A ambos foi retirada a referencialidade primeira. Izé perdera o sentido que mais lhe valia, o que sempre o guiara e de onde provinha seu maior prazer, o de ver. Simplesmente, ver. Ao leitor fora retirada a ilusão de um referencial externo ao texto, insinuada pela nomeação inicial do personagem, coincidente com o nome do autor.

o dito relance marca o momento da transformação, em que, impelido por forças que não pode controlar, o personagem se sente obrigado a um total redimensionamento, porque agora não lhe serve mais a pura racionalidade de que se vinha valendo, saibamos embora de sua não veracidade.

O que ele fará, na verdade, será conduzir em outra direção as formas de representação que utilizava antes, pois, embora afirme, de início, não acreditar em feiticeiros, ele enumera em seguida várias superstições suas, incluindo fórmulas mágicas de proteção, trazidas por escrito e, mais adiante, o desejo de erguer em meio à mata um altar a Pan.

Posteriormente, o narrador reconhecerá o absurdo da diferenciação que criara entre a religiosidade mais prestigiosa e aquela que era relegada em sua comunidade. A sua retratação é mais que a passagem de panteísta a crente ritual; é o reconhecimento, por meio de um olhar internalizado, experimentado, do funcionamento de toda uma rede simbólica e, através dela, da engrenagem social do poder. Não é em vão que a "bandeira branca" que ao final estende a Mangolô, o feiticeiro local, é "uma nota de dez mil réis". Anteriormente subjugado pelos poderes mágicos do mandingueiro, Izé subjuga-o, por sua vez, pelo dinheiro, comprando assim a sua misericórdia.

Sentindo-se perdido, dá início a uma luta contra o medo, ou seja, contra si mesmo, o que também constitui parte do jogo, já que ele passa a ser testado, à distância, pelo pai-de-santo. 
Dado o relance, a mata tão conhecida passa de local paradisíaco a labirinto amedrontador, do qual é preciso fugir. Izé penetra ali como um Teseu, seguro pelo fio tênue da sua racionalidade, e sai de lá como um Minotauro, tendo que enfrentar sua própria animalidade, guiado apenas por seus instintos.

O mundo passa a ser percebido por ele exatamente a partir da ausência de referente. Como em qualquer jogo, através do risco ele cria oportunidades e busca seu lugar. Após o primeiro e desesperador momento de cegueira, recorre à palavra mágica (ou religiosa) em busca de solução, utilizando a mesma oração que antes ironizava. Restabelece-se o lúdico no mesmo sentido em que aparece na epígrafe, como local da interação que permite uma reelaboração perante a realidade.

Toda a segurança que mantinha a princípio apoiava-se na ideia de luz; por extensão, de clareza racional. Nelas se baseia a resposta que dá a Sá Nhá Rita Preta quando esta lhe recomenda que não irrite Mangolô:

Bobagens! No céu e na terra a manhã era espaçosa: alto azul, gláceo, emborcado; só na barra sul do horizonte estacionavam cúmulos, esfiapando sorvete de coco; e a leste subia o sol, crescido, oferecido - um massa-mel amarelo, com favos brilhantes no meio a mexer.

Na sua trajetória retilínea pela vida, bastava-lhe, como segurança de continuidade, a simples claridade do dia. É como se formulasse com o dito popular: "se a gente não vê, não há", na postura mais comum do cético, esquecido do imponderável, da tragédia, da cegueira e da morte.

Quando a luz lhe é retirada, ele precisa descobrir uma nova maneira de ver, porque fica, repentinamente, sem o costumeiro referencial. As coisas estão todas lá, mas ele não as pode enxergar. Ou seja, o mundo segue seu curso sem a pretensa intervenção da sua presença, o que serve ainda para conscientizá-lo de sua posição diante do universo: "Então eu compreendi que a tragédia era negócio meu particular, e que, no meio de tantos olhos, só os meus tinham cegado; e, pois, só para mim as coisas estavam pretas. Horror!...”. 
Trata-se de um momento epifânico, a partir do qual o personagem irá reaprender a se guiar, no amplo sentido da palavra, valendo-se então dos outros sentidos que estavam antes embotados, como está agora a sua visão. Guia-se pelo tato e pela audição, até poder refazer o percurso, que desta vez o levará à cabana de Mangolô, onde se encontra em efígie. Neste momento não lhe valem mais a clareza, a ideia de racionalidade, o orgulho advindo de seu status com relação ao pai-de-santo. Repentinamente tomado ao seu mundo como marionete do feiticeiro, ele reconhece instintivamente que agora é preciso lançar mão das regras de outro jogo, no qual não lhe vale mais o pensamento lógico, pois invadira o terreno do mágico, do lúdico.

Ao leitor, cabe também assumir os riscos de sua caminhada pelo texto, desde o início expositor de suas próprias armadilhas. Este, ao mesmo tempo que deseja um leitor que aceite sua dupla face, oferece as pistas para que seu parceiro possa jogar com ele.

Não se pode afirmar até que ponto o feiticeiro que constrói o seu vodu tem a consciência do simbólico que arma, mas sabe-se que aquele que está tomado do sentimento religioso investe, além da carga de afetividade, grande força imaginativa, o que considera elemento mais importante para os objetivos que almeja do que os objetos concretos sobre os quais atua. Tanto é assim que não há no seu ritual a necessidade, por exemplo, de que o "boneco" em cuja materialidade intercede se pareça, de alguma forma, com a pessoa real que tem como alvo. Daí poder-se deduzir alguma consciência da dessemelhança envolvida no ato simbólico.

Do escritor, diferentemente, é cobrada - dele, do leitor, do crítico -, a cada passo, a consciência do jogo armado, sem a qual corre-se o risco de arbitrariedade na escritura e na leitura.

A capacidade de simbolizar - que parece envolver sempre um determinado grau de consciência - permitiu-nos comparar neste estudo o ritual religioso e o texto literário, apesar do evidente distanciamento entre suas formas. O alcance do sistema simbólico armado pelo ficcionista é imprevisível, porque dependente da sensi- 
bilidade criativa e da vivência do seu futuro leitor, residindo mesmo aí o segredo de sua dinâmica antitotalitária. $\mathrm{O}$ ritual mágico tem uma maior clareza de objetivos e, por isso mesmo, um campo de atuação mais restrito.

$\mathrm{Na}$ arte propriamente dita, a verossimilhança excessiva e intencional tem o dom de iludir, confundindo o leitor e despertando nele, muitas vezes, a necessidade um tanto nostálgica - primária no que respeita à vivência do texto ficcional - de unir aquele universo (de papel ou de pixels) à realidade circunstancial.

Acreditamos que considerar o texto literário como espaço lúdico é restaurar as possibilidades de vivenciá-lo no que tem de mais específico: o fato de estar aberto caleidoscopicamente a novas formulações, onde atua o leitor, preenchendo com seu próprio imaginário as lacunas deixadas por aquele. A narrativa rosiana, ao mesmo tempo em que declara a imprescindibilidade de um espectador ativo, impõe sua visão múltipla sobre uma base material única; entretanto, desdobrável ao infinito. 


\section{REFERÊNCIAS}

ALIGHIERI, Dante. A Divina Comédia. São Paulo: Abril Cultural, 1979.

ARISTÓTELES. Poetica. Tradução de Juan David Garcia Bacca. Mexico: Universidad Autonoma, 1946.

BARTHES, Roland et al. Literatura e Realidade: Que é o Realismo? Rio de Janeiro: Publicações Dom Quixote, 1984.

COSTA LIMA, Luiz. Mimesis e modernidade. Rio de Janeiro: Graal, 1980. MONTERO, Paula. Magia e Pensamento Mágico. São Paulo: Ática, 1990.

ROSA, Guimarães. Sagarana. Rio de Janeiro: Nova Fronteira, 1984. 


\section{CAPÍTULO 4}

RENATO PACHECO:

DUAS FACES DA ORFANDADE EM FUGA DE CANAÃ 
Para quem não tem mais pátria, é bem possível que o escrever se torne sua morada. Adorno 


\section{HERMAN E O EXÍLIO NA TERRA NATAL}

Numa tentativa de resumir o enredo de Canaã, pode-se dizer que o romance de estreia de Graça Aranha é a obra que dá voz à problemática da imigração alemã para o Espírito Santo no final do século XIX. Considerado por alguns críticos, como Ronald de Carvalho, "o precursor do romance de idéias" no Brasil, Canaã constitui-se de longos diálogos entre as personagens Lentz e Milkau, ocasiões em que cada um dos imigrantes argumenta em defesa de suas ideias acerca do fluxo migratório e suas consequências e das possibilidades de desenvolvimento da colônia. As palavras de Lentz propagam "ecos nietzschianos"109, defendendo a guerra, a luta pelo poder e a moral do mais forte; as de Milkau contemplam pensamentos humanitaristas que dão forma ao seu projeto utópico de construção da nação brasileira com base no amor e na solidariedade.

O romance Fuga de Canaã: decadência de uma família alemã, no Brasil, de Renato Pacheco, publicado em 1981, constitui junto com o romance de Graça Aranha, a partir das re-significações que lhe dá, um percurso ficcional em que surge como mais que uma bela homenagem ou que um simples ensejo de dar continuidade ao enredo daquele. Para além da importância que enceta ao recuperar fatos e personagens da história de Porto do Cachoeiro (Santa Leopoldina) e do Espírito Santo, seu texto trabalha também interna- 
mente, lançando questões acerca dos estatutos de real e de ficcional e empreendendo, acima de tudo, novas estratégias de criação da verossimilhança, como veremos a seguir.

Se o romance de Graça Aranha narra as desventuras daqueles alemães exilados em terras capixabas e sedentos, cada um a seu modo, de verem surgir a "nova terra", o texto de Renato Pacheco tem início com a narração de um exílio paradoxal: o pastor Fischer, após ter-se mudado de Santa Leopoldina (o antigo "Porto do Cachoeiro" que figura em Cana ã) para o sul do país, manda de volta o filho rebelado, o heterodoxo Herman Fischer, para que o reconheça e para que se reconheça no lugar em que nascera. Tem início, assim, o ambivalente exílio do rapaz na própria terra natal.

Ao mesmo tempo, estabelece-se em Fuga de Canaã o que se poderia denominar um jogo entre o lógos e a escrita, o lógos representando ao mesmo tempo o pensamento vivo, a fala (em oposição à escrita), a filosofia e a ratio. 0 jogo tem início com a forma como Herman Fischer se dirige a seu pai, o pastor, através de cartas: “Porém, meu pai, prevejo que algo me libertará, breve, de meu exílio em minha própria terra natal, e, porque o senhor não responde às minhas cartas, não mais lhe escreverei, esperando, pai, aqui e agora, hoje e sempre, ser compreendido e perdoado"110.

Cabe perguntar: por que o filho escreve cartas para as quais não obterá respostas? Quais as suas reais motivações? Ora sua carta é um presente envenenado (um phármakon, na acepção derridiano-platônica), porque através dela ele solicita o perdão do pai ao mesmo tempo em que lhe incute a culpa, a escritura assumindo a sua condição ambivalente entre bem e mal e, pela ausência da voz viva do pai - característica do lógos -, a sua própria orfandade. É de se notar também o traço da dupla impossibilidade de diálogo: através da escrita, o filho emite perguntas sem resposta. O pai exila o filho e, ausente, não lhe concede sequer o direito à palavra. A escrita é, como Herman, órfã, e o órfão, por sua vez, é sempre já um 
semimorto, pois lhe falta a presença do pai e da sua voz.

O fato de não haver nunca resposta às cartas também é significativo. Sem obtê-la, Herman então envia aos céus a sua palavra. Mesmo em pleno exercício da rebeldia, quando abjura a moral e a religiosidade paternas, o filho continua agindo - melhor dizendo, reagindo - em prol e em busca do perdão. Até mesmo a partir do sobrenome, que é a marca da continuidade da presença do pai, Herman ainda o re-presenta, apesar de que encaminha para uma outra significação, mais concreta, o sobrenome Fischer: o pai é, no seu dizer, "pescador de homens"111, enquanto ele se encaminha para a vida que deseja, de pescador no sentido literal. O silêncio, a recusa do pai a dar uma palavra-resposta é, paradoxalmente, prova ainda maior de sua soberania e onipresença. O discurso de Herman semeia a dúvida sobre a quem estaria ele se dirigindo, ao ter iniciadas as suas frases com o vocativo "Pai", que designaria não só o pastor Fischer, mas também o próprio Deus, como ocorre nas orações. O pedido de perdão que a princípio seria enviado ao pastor é, devido à ausência deste, encaminhado aos céus e, então, num curioso movimento de reversão, agora o pastor não é o representante de Deus, mas é o próprio Deus quem substitui o pastor, num lance inesperado desse jogo de substituições. A voz do pai, a sua lei é tão constante na consciência do filho que não mais necessita fazer-se ouvir - ela soa onipresente, como a voz de Deus.

A ambivalência típica da escrita reflete na figura de Herman, filho sem pai e exilado no lugar onde nascera. Por meio da carta, ele envia a prova escrita de seu próprio desregramento e do de todo o rebanho: "Pai: Vou escandalizar sua moral luterana - casei-me, faz três meses, no rito católico, e já sou viúvo. - Confessei, comunguei. Abjurei, fiz o diabo"112. Herman dilui a própria "heterodoxia" em meio ao que considera a imoralidade geral nos costumes dos descendentes de imigrantes luteranos: "(e não lhe falo na moral sexual da colônia que é a pior que se possa encontrar)" ${ }^{113}$. Como ovelha desgar-

111 Idem, p. 24.

112 PACHECO, 1984, p. 17.

113 Idem, p. 41. 
rada, renegada pelo pastor, redime-se, a um tempo em que também aponta na direção do pai com a lembrança da culpa: se toda a comunidade está perdida e ele ainda consegue relatar-lhe os malfeitos é porque se encontra em posição de destaque. E ainda: se o rebanho se perdera, o mau direcionamento viera da incompetência de seu antigo pastor, que não soubera conduzi-lo: "O senhor é um autêntico, um verdadeiro luterano, o último dos luteranos. O senhor só aceita amor e medo de seus subordinados"114.

Segundo Herman, a ortodoxia do pai é tão completa que ele se encontra sozinho nela. Ou seja, é um pastor tão leal que, paradoxalmente, não consegue conduzir as ovelhas desgarradas. Nesse ponto, Herman é o súdito que indica ao superior a sua dupla falha, como pai e como pastor, e que ascende assim, temporariamente, a um plano superior ao do pai, inferiorizado, manchado pelas mazelas do seu antigo rebanho. A carta é o presente envenenado em que o filho declara sua negação do poder e do trabalho paternos:

Até os seus luteranos, grupo monolítico em seu tempo, indisciplinados estão se desagregando, paulatinamente. Em Santa Maria uma moça que estudou com as freiras hoje é católica; um filho de pastor se apaixonou por uma professora e se converteu também. Os ricos Schultz brigaram com o Pastor e ameaçaram mudar em massa (não para o catolicismo mas para o luteranismo da Missão do Missouri, americanos degenerados (segundo os pastores) e que estão entrando aqui agora, com muita propaganda e tenacidade) ${ }^{115}$.

A religiosidade de Herman aproxima-se em muito do panteísmo de Milkau, de Graça Aranha, mas um traço importante também diferencia os dois: o amor que Milkau propõe como solução permanece num patamar romântico de idealização, irrealizável, enquanto Herman Fischer tanto inspira quanto colhe os frutos de um amor solidário: segundo o relato de Helmut Jank - no qual não se tem mais

114 Ibidem, p. 17.

115 Idem, ibidem, p. 40-41. 
motivos para não crer que nos demais -, também entre ele e Herman se estabelece uma relação afetivo-sexual, a ambos satisfatória, depois de Herman ter vivido com as duas irmãs Jank, tendo estado sempre emocionalmente envolvido, no entanto, com a mulher que lhe era proibida, a professora negra Agnela.

Um forte traço de incompletude permeia cada uma das relações de Herman com as três mulheres: Maria, com quem se une, já se casa grávida de outro e jamais lhe permite (a Herman Fischer) qualquer contato físico; com Berta ele se associa por caridade e como resultado da insistência dela, e a Agnela, que é para onde aponta o desejo, todos os preconceitos e tabus daquela sociedade se contrapõem. Com Helmut, a ligação, além de socialmente proibida, só nos chega através das declarações de um "doente mental" - que é como Helmut passa a ser considerado - a um psiquiatra, a veracidade ou não dos fatos sendo mais um mistério que envolve as páginas de Fuga de Canaã.

É importante insistir em que Herman fora "exilado" (termo seu) pelo pai-pastor na sua própria terra natal, numa representação máxima de o quão paradoxal é a situação que vive: natividade e exílio se confundem, numa relação intertextual instalada desde a polêmica que envolveu as misteriosas condições de nascimento-e-morte do filho de Guilhermina Lubke, “recriado” por Graça Aranha nas páginas do romance Canaã. O bebê de Guilhermina, vale lembrar, é devorado por porcos, na mata, depois das tentativas desesperadas da parturiente de conseguir abrigo na casa do pastor, de onde é enxotada sob a alegação de que o lugar é "uma casa de respeito, a morada de Deus" e de que teria abrigo "[...] Se este lugar não fosse sagrado... Se não fosse terrível a morada de Deus!"116. O pastor de Canaã também criava os seus exilados, semimortos ou natimortos.

A orfandade que medra sutilmente na relação entre Herman e o pai avulta sem limites na narrativa por evento da morte do velho Helmut Jank: os filhos, além do desamparo pela ausência da figura 
paterna, tão terrivelmente marcante no tipo de comunidade em que vivem, encenam uma vez mais a necessidade e a impossibilidade de comunicação. É que, primeiramente, não dominam o português, idioma em que deve ser feito o inventário dos bens deixados. Ao mesmo tempo também, como se verá, não têm conhecimentos suficientes do alemão, a sua língua "de origem". Sem pai, sem língua e expatriados, eles se veem obrigados a recorrer, para dar curso ao perpasse da herança, às habilidades do indesejado Herman Fischer e da professora Agnela, ambos até então - e não menos depois disso - alvos de sua discriminação, ele por ser um luterano pouco ortodoxo, e ela por ser negra. Tem início, assim, a problematização sutil das questões de idioma e de nacionalidade, lançadas na epígrafe que encabeça este nosso texto.

Herman e Agnela são os únicos na casa que não se envolvem na contenda iniciada por ocasião da distribuição da herança e também são os que melhor conhecem o código escrito a que os imigrantes têm que submeter a propriedade deixada. Na cena da realização do inventário, crescem de um lado as falas descontroladas dos Jank, enquanto por um outro Agnela e Herman "dão ordem" à herança deixada pelo patriarca. Nesse sentido, todo o conjunto da ordem "puramente" oral se submete à escrita, e à escrita dos rejeitados. Pelas mãos que grafam a escrita sorrateira, deslizam, enfim, os bens da família. No dizer da professora Agnela:

Berta e Franz se degladiaram (sic) numa luta como que há muito pressentida, e para a qual eles vinham se preparando a vida inteira. Por isto, e para minha felicidade, Herman e eu ficamos encarregados de fazer a lista do que havia na venda, sob os olhos suspeitosos de Berta e (principalmente) de Franz. Parece que ia iniciar-se uma dessas longas e falsas questões, causa de tantos escândalos e ódios entre famílias teuto-capixabas ${ }^{117}$.

117 PACHECO, 1984, p. 102. 
O órfão Franz, que se mata após a morte do pai, da mãe e da irmã, encontra dificuldades até mesmo para deixar o seu bilhete de suicida, que resulta praticamente ininteligível, escrito que fora no seu "mau alemão". Suprema ironia e triste condição de um ser desde sempre e já expatriado em qualquer das duas terras; ele se encaminha, com a morte, para uma nova comunidade, imaginária; sem conhecimento da palavra, permanece mudo em qualquer das duas línguas: "'Waron wil tu dig tot mahen blitet dem die leiber Gott am das ser Hehüte fom dizem Basser. Amém'. (No mundo onde ficar eu, meu Deus, guardai-me para que não pague por isto. Amém)"118. 0 pomerano aparece assim, na sua impureza ambivalente, como um "meio-termo" entre o português e o alto alemão.

Do mesmo modo, a morte do velho Jank - na versão escrita por Franz, enviada ao irmão Helmut na capital do Estado, e posteriormente narrada por este ao psiquiatra - tem suas circunstâncias postas em dúvida devido a "aquele alemão estropiado lá dele"119, o que faz duvidar - no caminho intertextual traçado de Fuga de Canã̃ a Canaã - da suposta veracidade dos relatos e, especialmente, desse relato sobre um outro relato. A obsessão pelo factual, nesse crime como também naquele dos autos que inspiraram Canaã, mostra-se inútil e põe em xeque todo o percurso jurídico-científico que agrega a si o direito de desvendar e julgar os casos.

Uma outra via de leitura das relações entre os dois romances poderia partir da observação das relações entre os paradoxais Herman e Helmut, em Fuga de Canaã, e do gérmen dessa relação presente já no contato entre Maria Perutz e o pastor-acusador em Canaã, "refletindo", por sua vez, o contato entre Guilhermina Lubke e o pastor Hasenack - avô literário de Herman Fischer -, cujos depoimentos foram subscritos pelo juiz de direito, doutor José Pereira da Graça Aranha. 


\section{HELMUT, O HERDEIRO BASTARDO}

Provavelmente a relação filial que primeiro salte aos olhos em Fuga de Canaã seja a que o liga intertextualmente ao romance Canaã, de Graça Aranha, o que se percebe já a partir do título. Sustentando esse liame, que a princípio enovela externamente a tessitura dos dois romances, despontam também relações internas de filiação.

Uma dessas relações se estabelece a partir da aparição, no romance, de Helmut Jank, personagem que se autodenomina "neto" de Maria Perutz, personagem de Canaã que tivera sua criação "baseada em pessoa real". A partir desse fato, o gérmen da paternidade esgarçada daquele universo de papel floresce. E, se bem o notarmos, o fato de Renato Pacheco criar personagens que descendem de outras, também ficcionais, paradoxalmente, ao invés de diminuir a ilusão de real que as cerca, atribui a elas um ainda maior estatuto de realidade, dando provas, mais uma vez, da "medida" ilimitada da verossimilhança, ou seja, de sua independência do contexto externo.

Explicando melhor: quaisquer provas da existência factual daquelas histórias e pessoas que inspiraram Canaã desinteressa para a formação, no leitor, de uma sensação de realidade. No entanto, o fato de um personagem como Helmut indicar a sua ascendência naquela outra ficção, como que expande o raio de atuação dos acontecimentos do seu universo ficcional até a vida inventada dos ancestrais e àquele outro universo de relações que é o romance de Graça 
Aranha. Assim, não só a sua existência reforça as anteriores, como também o contrário. É o próprio Helmut quem comenta: “[...] eu era um encantado, um neto de uma personagem de romance: que achado, que prato para os suplementos literários [...]"120. E é assim que a ampliação do raio ficcional de Fuga de Canaã amplia também o foco da ilusão referencial.

Juntamente com a arregimentação dessa ancestralidade literária para Helmut Jank tem início um subliminar, porém profundo, questionamento acerca dos limites e deslimites da ficção. Renato Pacheco, em outras obras, anteriores e posteriores a Fuga de Canaã, fizera sobressair essa mesma interrogação. Aqui, ainda uma vez, a questão é o quanto de realidade se faz necessário para criar ficção, e, a partir do jogo de ilusão referencial que perseguimos em Fuga de Canaã, já é possível acrescentar a essa interrogação um "vice e versa", ou seja, que cota de ficcionalidade acrescentará realidade ao texto?

Diante de toda a curiosidade sobre a probabilidade dos relatos que costuma cercar um texto dito "baseado em fatos reais" - como é o caso de Canaã -, os próprios personagens de Fuga de Canaã muitas vezes ensaiam respostas ao propósito de veracidade. No dizer de Helmut Jank: “[...] A verdade querem saber todos, mas a verdade não existe" ${ }^{121}$.

Essa escrita "segunda", que é a de Fuga de Canaã, realizada sobre outra "segunda" escrita, que é o romance de Graça Aranha, em vários pontos indaga o estatuto que é ao mesmo tempo a infelicidade e a glória de Canaã (o que atrai e o que arrisca, ao mesmo tempo, empobrecer-lhe a leitura): "basear-se em fatos reais".

O texto de Pacheco introduz aí uma fissura, ao "assumir-se" - através da criação das relações de filiação literária a que viemos nos referindo - "baseado em fatos irreais", quando cria um personagem descendente de outro, também fictício, e ainda quando mistura personagens reais e fictícios em um mesmo enredo, como 
se dá no caso de Helmut, que se declara neto não só de Guilhermina Lubke, nome da pessoa real (lembrando sempre que dela o que temos nos chega por meio de vários tipos de relato: o oral, dela própria; os das testemunhas e os dos acusadores, documentados nos autos do processo; o escrito, conjunto dos textos do próprio processo; o romance de Graça Aranha, baseado nos autos, e o texto de Pacheco, "baseado" no de Graça Aranha), como também de Milkau, personagem de Canaã: “(...) minha avó Guilhermina (Mina, a Maria do livro) subiu com o amante, talvez meu avô, as serras do Luxemburgo, em busca do céu"122. E adiante: "A mata era nossa, e o nome lembrava apenas o antigo proprietário, a quem o meu avô, Milkau, a tomara, por dívidas não saldadas nem honradas"123. E se essa "secundariedade" das escritas é sempre questionável, o de que se duvida, por detrás delas, é mesmo da possibilidade de apreensão do relato e/ou do fato originais.

É interessante notar como esse duplo afastamento de uma suposta realidade vem a provocar a intensa sensação de estarmos diante de seres reais. Percebe-se assim um movimento, um fluxo vertiginoso que emaranha vida e obra, realidade e ficção através da escrita, e que, por um lado, partindo de Fuga de Canaã, faz buscar em Canaã o seu gérmen, no jogo de filiação que cria um neto para Maria Perutz e, por outro, lança os seus tentáculos também para a realidade externa, propondo sutilmente que: se a Maria Perutz de Canaã deve sua existência em parte à Guilhermina Lubke - cuja trágica morte do filho fora registrada nos autos do processo no final do século XIX -, o surgimento de um seu neto literário faz pensar num movimento que segue no sentido contrário: nas possibilidades de uma existência real para um descendente daquela que fora a infeliz inspiradora do texto de Graça Aranha.

É como se um futuro amante de Guilhermina Lubke tivesse passado a ser nomeado Milkau, por influência reversa da ficção 
sobre o real, e a partir de então se desse a linha de descendência que resulta no surgimento desse ser híbrido entre real e ficcional, que é Helmut Jank. O fato de Helmut ser considerado louco abre as possibilidades de que se crie essa dupla realidade (ou dupla irrealidade), por isso é nos seus relatos que ela mormente desponta: a ele, enquanto hospedeiro dos bruxuleios razão-insanidade, é permitido também habitar um território móvel entre real e ficcional. É ele próprio quem indica a ambivalência de sua condição, a partir de seus anseios:

Sonhava (sonho ainda) com um homem-caramujo, rosa-vermelho, hermafrodita, íncubo-súcubo, súcubo-íncubo, que um dia há de nascer, por mutação, e que seja capaz de fecundar-se fecundando, num supremo gozo, e que saísse por aí, em noites de lua, em busca de seu par sagrado a fim de gerar uma raça de super-seres, não-homens, não-mulheres, mas ambos [...] ${ }^{124}$.

Helmut Jank, herdeiro e bastardo, a um só tempo caçula e adotivo, recebe da mãe - na procura dela por um disfarce que acaba soando irônico - o nome do pai legítimo. Esse filho não-filho do velho Jank é também grandemente perturbado pelos fantasmas que compõem - e decompõem - a sua relação com o pai: "Eu bamboleio entre o bem e o mal. Andei na corda, no fio, com o abismo do Luxemburgo em baixo (sic). Meu pai só dava atenção aos três primeiros filhos, Berta, Franz e Maria... Parece que não era meu pai, não sei por quê"125.

Um ponto ainda enriquece a ambivalência dessa posição representada sobretudo por Helmut: não é ele o único dos personagens de Fuga de Canaã a referir o sobrado construído por Milkau ou a árvore plantada por Mina, o que inclusive retira as suas declarações, feitas dentro do mundo daquela ficção, a conotação de delírio psicopático, indicando que se trata muito mais de uma questão do universo literário.

Essa personagem que liberta o seu desejo sexual por outra do 
mesmo sexo, em plena colônia de imigração luterana alemã, no interior do Espírito Santo, em meados do século XX, encena uma dupla rejeição da função paterna - entendida, obviamente, no sentido tradicionalmente aceito, a partir do seu enfoque psicanalítico como lugar da lei que restringe a liberdade do filho: ela contraria a "masculinidade" do pai e o desejo de continuidade deste "administrador" da família para o perpasse da herança, nas várias acepções do termo.

Helmut, além das acusações de insanidade mental, das proibições por que passa o seu desejo sexual e do convívio com o ódio ou com a indiferença do pai, devidos às suspeitas de bastardia, ainda se percebe diferente dos demais e comenta: "feio, pequeno, moreno (entre louros teutos), barbudo comecei, para mal de meus pecados, a coxear também"126. Sua constituição física contempla vários dos índices de rejeição presentes na comunidade, compondo com eles uma espécie de bomba-síntese daquelas preconceituações.

Alguns pesquisadores da relação fato-relato em Canaã afirmam que praticamente todos os personagens tiveram a sua existência devida a pessoas reais, o que não impede o leitor de tentar abolir a ânsia de comprovação, inócua perante a riqueza das personagens, ou a obra de questionar a pureza dos estatutos de ficção e realidade, especialmente por meio da relação com Fuga de Canaã, a partir da qual nos é reapresentada.

Para melhor acompanharmos o "caso [de] Helmut", seria bom relembrarmos a afirmação de Antonio Candido de que a expressão comumente usada para definir personagem - "ser fictício" - é ela própria paradoxal, já que indica a existência do inexistente. Segundo o grande crítico, a criação de personagens "oscila entre dois pólos ideais: ou é uma transposição fiel de modelos, ou é uma invenção totalmente imaginária"127. A nossa proposta é de que se amplie à radicalidade a sua posição, tendo em mente que, no jogo paradoxal da construção de personagens, a dita transposição fiel de modelos 
simplesmente não existe, porque não resiste ao gérmen da invenção; e nem a invenção totalmente imaginária pode escapar de passar pelo seu contrário, já que todo imaginário é de antemão formado pelos retalhos do empírico.

Com relação aos fatos que inspiraram Graça Aranha, as principais peças do processo, aberto em 1889, e que termina por incriminar Guilhermina Lubke (autuação, interrogatório, auto de corpo de delito e mandado de prisão, entre outras), são reproduzidas por Augusto Lins no livro Graça Aranha e o Canaã, que guarda vasta documentação acerca dos fatos nos quais se basearia o romance. Lá é possível ler as reproduções dos documentos oficiais, o registro escrito dos relatos da acusada, dos acusadores, dos julgadores e das testemunhas. Entre eles, o trecho que tanto impressionara o juiz José Pereira da Graça Aranha, relatando a descoberta do filho morto de Maria Perutz, "[...] cujo cadáver que estava com uma corda atada ao pescoço e a cabeça esmagada dentro de um caixão era de cor branca, de sexo masculino e estava nas proximidades de um chiqueiro de porcos $[. . .]^{\prime 128}$.

Compare-se à cena do nascimento em Canaã a forma como Helmut imagina um parto para si, saindo como um verme de dentro do cadáver da mãe, afiliando-se desse modo à rede de estorvos órfãos, semimortos, natimortos ou mortos-vivos desse conjunto ficcional: "No enterro (mais no dele que no de mamãe, minha amiga) eu me sentia um verme e não um homem, que intranqüilo e desassossegado saíra das entranhas de minha mãe, morta"129. Invertendo a situação do romance de Graça Aranha, aqui é o filho que se sente nascer de uma mãe morta, enquanto naquele a dúvida que paira é sobre o nascimento (vivo ou morto) do bebê de Maria Perutz.

Desse modo, criando personagens descendentes dos de Graça Aranha, o escritor Renato Pacheco, conhecedor do percurso livre e sub-reptício da escrita entre ato e relato, opta pela via oposta à dos 
estudos documentais sobre Canaã. Estes foram em busca das raízes extraficcionais do romance, constituindo contudo, e mais uma vez - a despeito de todo o desejo de real que encenam -, uma série de relatos sobre outros relatos, orais ou escritos.

Já no texto de Pacheco, emaranhando ainda uma vez fato e relato, o narrador, inteirado de o quanto há de ficcional em cada declaração e da impossibilidade de um puro resgate histórico dos acontecimentos, ironicamente comenta, ao citar uma passagem retirada dos autos: "(como o diabo do homem soubera que a madrugada era fria; devia ser, agosto é sempre frio, na serra)"130, demonstrando assim consciência de questões que envolvem o próprio fazer literário em desprezo ao factual relatado.

Ao contrário do que acontece comumente, a interpretação que faz dos autos do caso de Guilhermina não lhes ignora a condição de relatos e não encena uma perseguição do real através de suas linhas. Poder-se-ia dizer ainda que o narrador de Renato Pacheco é, muitas vezes, uma espécie de escritor. No caso acima, a supervalorização do relato, a pergunta sobre ele - como é que ele sabia? - aponta ainda uma vez para o real externo, contextual, no jogo infindo de contradições que enreda a ficção. 


\section{REFERÊNCIAS}

ARANHA, Graça. Canaã. 2 ed. Rio de Janeiro: Nova Aguilar, 1977.

BOSI, Alfredo. História concisa da literatura brasileira. 3 ed. São Paulo: Cultrix, s/d.

CANDIDO, Antonio et al. A personagem de ficção. 9 ed. São Paulo: Perspectiva, 1995.

CULLER, Jonathan. Sobre a desconstrução: teoria e crítica do pós-estruturalismo. Tradução Patrícia Burrowes. Rio de Janeiro: Record: Rosa dos Tempos, 1997.

DELMASCHIO, Andréia. Nomes pra viagem: Renato Pacheco: vida e obra. Vitória: Secretaria Municipal de Cultura, 2002.

DELMASCHIO, Andréia. Renato Pacheco. Vitória: Protexto, 2007. (Coleção Grandes nomes do Espírito Santo).

DERRIDA, Jacques. A farmácia de Platão. Tradução Rogério da Costa. São Paulo: Iluminuras, 1991.

FOUCAULT, Michel. Vigiar e punir. Tradução Raquel Ramalhete. Petrópolis: Vozes, 1995.

LINS, Augusto Emílio Estellita. Graça Aranha e o Canaã. Rio de Janeiro: Livraria São José, 1967.

PACHECO, Renato José Costa. Fuga de Canaã: decadência de uma família alemã, no Brasil. Vitória: FCAA, 1981.

PAES, José Paulo. “Canaã” e o ideário modernista. São Paulo: EDUSP, 1992. 



\section{CAPÍTULO 5}

EVANDO NASCIMENTO: CANTOS PROFANOS 



\section{“TENTAÇÃO DOS SANTOS”: PECADO, CONFISSÃO E PERDÃO}

"Tentação dos santos", conto que abre o livro Cantos profanos, de Evando Nascimento, constitui-se da revelação de um ato de violência sexual, discurso em que se dispõe unicamente do ponto de vista do homem que narra. Feita ao mesmo tempo a um Padre e ao leitor, a confissão vai infundindo paulatinamente a dúvida quanto a um suposto desejo, por parte da vítima, de ser subjugada. Todos os sinais de medo e rejeição ao ataque, dados pela menina, são interpretados pelo seu algoz (ao menos é o que ele declara) como indícios de consentimento para as investidas sexuais. É algo que se nota também em diversos discursos misóginos produzidos e reproduzidos diariamente em grande parte da mídia nacional ${ }^{131}$. Nas palavras do violentador:

[...] pois regalou as pupilas de gazela para mim, seu cio, de noite é
que atinei o vício, palpitei, aproveitei a cunhada na missa, [...] em
lugar de amaciar com mimos, fui reto ao assunto, uns desmesu-
rados centímetros, bem grosso, rígido, perdoe o despudor, tenho
orgulho, ficou sem fôlego, desejando muito, logo vi, mas, com pavor
das primícias, o que não se aguenta de prazer, fingiu que não queria,
a bandidazinha, pois ansiava, amuou [...] se queria, claro que sim,
mas negaceava, ares de fêmea [...] dia seguinte recomecei o manejo
[...] relutou bastante, podia ter puxado o zíper da saia, num golpe,

131 Acerca da cultura do estupro no Brasil e de dados mais recentes, conferir: AGÊNCIA PATRÍCIA GALVÃO. Disponível em: <http://agenciapatriciagalvao.org.br>. Acesso em: 20 ago. 2017. 
contentei chupando o fruto de vez, escoiceava, Não quero machucar, eu disse, Está me machucando, respondeu (NASCIMENTO, p. 17) ${ }^{132}$.

O fato de o leitor contar apenas com o relato do homem, além de remeter diretamente à realidade de um patriarcalismo violento, em que mesmo as supostas verdades da vítima, em geral, são veiculadas por uma voz outra, que não a sua, também é responsável por instaurar, de modo sutil, a dúvida sobre os limites entre medo e desejo ${ }^{133}$. É importante deixar claro que não se trata simplesmente de, na leitura do conto, assumir-se um lado ou posição. Sabe-se que os variados tipos de discurso (não só o ficcional) criam e alimentam diferentes tipos de fantasia. Assim, há um movimento em que, expondo delicadas questões de ordem ética, a literatura pode ser não apenas a ponta de um iceberg discursivo, mas também a provedora de uma vasta rede de discursos, a qual, nesse caso específico, engloba a complexa questão do desejo ${ }^{134}$.

O conto de Nascimento explora a promiscuidade, para muitos insuspeita das relações entre sexo e religião, ficando ao encargo do leitor perscrutar as inúmeras implicações que podem advir dessa mescla, tanto quanto o resultado dela na vida cotidiana. E é por meio da confissão feita ali que se percebem os inarredáveis liames entre os discursos erótico e religioso, além da relação entre pecado e perdão.

132 A partir desta, todas as citações sem identificação de obra devem ser entendidas como retiradas de: NASCIMENTO, Evando. Cantos profanos. São Paulo: Biblioteca azul, 2014.

133 O termo tentação já traz em si uma ambivalência, por fundir numa só palavra tanto a ação daquele que tenta, quanto a sensação daquele que é tentado. De acordo com o Dicionário Aurélio, tentação é tanto o a to como o efeito de tentar, uma "disposição de ânimo para a prática de coisas diferentes ou censuráveis". A terminação dúbia da palavra (em -ação) concorre para a criação da atmosfera também dúbia que se estabelece na narrativa. Ainda segundo o Aurélio, tentar é tanto seduzir quanto deixar-se seduzir (FERREIRA, Aurélio Buarque de Holanda. Novo Dicionário Aurélio de Língua Portuguesa. Rio de Janeiro: Nova Fronteira, 1994, p. 1943). 134 De modo geral pode-se afirmar que, em diversas sociedades, uma culpa de origem religiosa costuma cercar qualquer ato sexual. Diante dessa constatação, deve-se levar em conta que a questão de a menina querer ou não querer pode tornar-se uma dúvida até mesmo para ela própria, o que - é bom deixar claro - não nega a violência do estupro. Pelo contrário: a monstruosidade do ato revela e habita um espectro cultural maior, que envolve a condição a que a mulher é submetida em diversas sociedades, e que passa, sem dúvida, pela opressão sexual de fundo religioso e moral. 
Há interseções notáveis também com a obra do poeta baiano Gregório de Matos, conterrâneo do autor dos Cantos profanos. Para além do nome do santo ao qual é dirigido, prioritariamente, o pedido de perdão: "imploro clemência a todos os sãos, Gregório primeiro" (p. 18), a referência à obra de Gregório de Matos é ainda mais explícita no seguinte trecho: "pequei talvez, Senhor, mas nem porque pequei de Vossa imensa glória me despeço" (p. 17).

Padre jesuíta, o Boca do Inferno, como era conhecido, nos legou uma obra singular, da qual faz parte uma série de poemas satíricos e outros fesceninos, cuja fama, espalhada graças à sua divulgação oral, concorreu, ao lado de fatos de uma não menos singular biografia, para que o padre obsceno abandonasse a cena religiosa. Após séculos de recalque crítico e editorial, apenas a partir da década de 1960 foram trazidas a público mostras mais completas da sua produção, das quais enfim passaram a constar os textos pornográficos, que vão alcançar realce ainda maior no contraste com as partes religiosa e lírica da obra.

O traço que se quer destacar, porém, neste curto diálogo da poesia gregoriana com "Tentação dos santos", é a intrincada relação entre pecado e perdão, que, além de aparecer em conjunto nas diversas facetas poéticas do Boca do Inferno, foi sintetizada de modo muito bem acabado no seguinte soneto:

Pequei, Senhor; mas não porque hei pecado,

Da vossa piedade me despido,

Porque quanto mais tenho delinquido,

Vos tenho a perdoar mais empenhado.

Se basta a vos irar tanto um pecado,

A abrandar-vos sobeja um só gemido,

Que a mesma culpa, que vos há ofendido,

Vos tem para o perdão lisonjeado.

Se uma ovelha perdida, e já cobrada

Glória tal, e prazer tão repentino

vos deu, como afirmais na Sacra História:

Eu sou, Senhor, a ovelha desgarrada

Cobrai-a, e não queirais, Pastor divino,

Perder na vossa ovelha a vossa glória.

MATOS, Gregório de. Obra poética. 2 ed. Rio de Janeiro: Record, 1990, p. 69. 
Endereçado a Deus, o pedido de perdão resvala em uma certa chantagem, tendo em vista que a voz lírica expõe como argumento central, para provar o merecimento da remissão, justamente o pecado. Trata-se da mesma alegação feita pelo narrador do conto de Nascimento: "só o pecado redime, primeiro precisa pecar muito pra depois ser perdoado, até ser beatificado e por fim virar santo" (p. 19).

Num paradoxo típico da relação pecado/perdão, o que ressalta, no poema de Gregório de Matos, é a própria formulação do pedido, já que a razão para perdoar se encontra na existência mesma do pecado, por um lado, e no dom divino de perdoar, por outro. Ao pecador cabe apenas lembrar a Deus a existência do complexo mecanismo, para que seja acionado.

A voz lírica, durante a jaculatória argumentativa e chantageadora, praticamente afirma, sob a máscara da contrição, a necessidade de reconhecimento da reciprocidade do ato: o perdão só pode existir graças à existência do pecado. Por extensão, Deus, o remissor, tem a sua existência coatada à existência do pecador. Se o pecador depende do perdão, a recíproca também é verdadeira, o que transforma a falta cristã numa virtude - ou mesmo numa condição da cristandade. Logicamente, um verdadeiro cristão não é apenas aquele que peca, mas aquele que sabe pedir perdão, reafirmando, por meio das suas atitudes, a existência e a onipotência de Deus.

Dessa demonstração poética de reconhecimento da complexidade da relação pecado/perdão provém talvez o fato de soar irônica a declaração que se afirma ter sido dada por GM quando de seu declínio da batina:

Poucos dias antes pretendeu este Prelado com piedosas mostras persuadir ao poeta que tomasse ordens sacras, para conservar-lhe os cargos; mas ele respondeu com inteira resolução que não podia votar a Deus aquilo que era impossível cumprir pela fragilidade de sua natureza; e que a troco de não mentir, a quem devia inteira verdade, perderia todos os tesouros e dignidades do mundo (RABELO, Manuel Pereira. Vida e morte do excelente poeta lírico, o doutor Gregório de Matos e Guerra - Crônica do viver baiano seiscentista. Salvador: Janaína, 1969, p. 1702). 
$\mathrm{Na}$ “Tentação dos santos", como o título mesmo indica, ou, como aparece na expressão usada pelo narrador "tentação da inocência"135, tudo se desenvolve em torno de termos que cobrem ao mesmo tempo dois polos tradicionalmente tidos como bem mais que opostos - incompatíveis: a tentação (pecado) e a pureza (santidade). A iniciar pelo uso da palavra "jaculatória”, que designa, por um lado, os "mistérios gozosos" (orações curtas e fervorosas, lançadas pelos crentes como se em jatos - do latim: jactu), e que se liga a outras, de uso mais estrito no léxico dedicado ao campo sexual, como "ejacular", lançar esperma: "fracassei, a carne é triste, fraquíssima, descontrolada, daí essa jaculatória, imploro clemência a todos os sãos” (p. 18).

Seguem-se ainda expressões como o "sacro nome", enlaçando de um lado o sagrado e, de outro, pelo teor sensual da confissão, o profano, ao referir, de modo ambivalente, o sacro - osso das partes baixas, próximo das zonas erógenas: "violência, seu nome é virilidade, não pronuncio seu sacro nome em vão, meu Espírito Santo, e sei que a Madre Igreja está perenemente assentada em fundamentos inabaláveis como a fé" (p. 18). O vocábulo "madre", contagiado historicamente pela ambivalência, indica, de um lado, a chefe das freiras, mulher devotada à religião - por extensão à pureza, à castidade e à santidade - e, por outro, o útero, núcleo da procriação, situado portanto no espectro da sexualidade.

$\mathrm{O}$ ato violento mesmo se dá num intervalo sagrado: “aproveitei a cunhada na missa" (p. 16), mas não é de se desprezar o fato de que, para a "reles cadelinha" (p.17) - é assim que o abusador se refere à menina! -, a violência sofrida absurdamente já não é um ato isolado, nem um marco especialmente negativo na sua trajetória de vida: ela viera para a cidade em fuga da violência física que sofria por parte do pai e vive então numa casa em que trabalha em troca de comida,

135 Retomando-se o conteúdo da nota 3, pode-se ainda afirmar que na "tentação da inocência" o sentido mais tradicional de inocência se mantém? Ou seja, é a inocência mesmo que tenta, que atrai, ou será justo o que há nela de "tentação" que atrai? Mais ainda: ontologicamente, estará a expressão "tentação da inocência" indicando a tentação que há na suposta inocência ou a inocência que há na tentação? 
a casa da cunhada do narrador-estuprador, Inácia, cujo nome significa "norma de serviço, prescrição legal, regulamento" ${ }^{136}$. Ou seja, é antes do estupro (e depois dele, como indica o desfecho da narrativa) que a sua vida é invalidada: ao escapar temporariamente da vigilância da norma (Inácia) e do peso do trabalho escravo - "Inácia maltratava a guria" - (p. 16), a menina entra para outro campo de subjugação. Os poderes não deixam vácuo entre si, antes se alternam na exploração da força de mais aquele corpo.

Aliás, o palavreado beato que conforma a jaculatória confessional soa cínico, por se tratar de uma confissão de estupro, confusão entre os campos que, por fim, faz aderir um tom cômico à religiosidade trazida à baila. Revela o narrador, na sua profana confissão:

por volta do meio-dia serviu o almoço, malcomi, só tinha olhos pras coxas e pros mamõezinhos, a sobremesa, arrastei sem dó nem oh, pra cama, passei mãos, língua, abri as pernas, a buça, a bussantinha já peludinha, lutava mas não gritava, nem um pio, queria, sim, tomei tento, queria, fui rompendo estrada e muro, abri largo caminho, por quanto tempo, a verga, o negócio, o rijo engenho aplicado com arte, aprendiz não sou, assinalado varão, já sabe, carne nova, crua, fartei riscando indigestão, enfarte, quanto mais arredia mais saborosa, a presa [...] quer dizer, ao fim gemia [...] a bonequinha partida choramingava no canto, beijei, fiz carinho, quem mandou?, tremia de febre, banhei, dei chás, todos os que havia, consolei mais do que fui consolado [...] (p. 19).

A palavra "buça", redução de "boceta" (vulva) ecoa no neologismo "bussantinha”(p. 18). Este, por sua vez, tanto simula um diminutivo de buça, quanto traz, na composição da palavra, por derivação, uma ligação com o termo "santinha", espalhando assim, pela narrativa, a ideia de santidade, entranhada no léxico próprio do sexual.

O narrador violador tenta, ao seu modo, provar a sua santidade, argumentando que foi seduzido pela menina, que, por sua vez, seria o agente da "tentação": "de inocente não tinha nada, nem Imacu-

136 FERREIRA, Aurélio Buarque de Holanda. Novo Dicionário Aurélio de Língua Portuguesa. Rio de Janeiro: Nova Fronteira, 1994, p. 1082. 
lada, Virgem Maria, muito menos minha Sant’Ana, já nasceu com a sina, cria bastarda de ancestral culpada, Eva, o Mal do mundo, ovelha pra sacrifício dos homens, fui vítima em vez de carrasco" (p. 15). A confissão, gênero discursivo escolhido para a construção da narrativa, é revelada, desse modo, no seu aspecto ambivalente, já apontado por Foucault no volume I da História da sexualidade: é por meio do discurso confessional que em geral se espera deslindar os próprios pecados, para que se possa assim receber a posterior remissão - como ocorre no poema de Gregório de Matos.

Todavia, a confissão é também um meio de vazão para a sexualidade, que é trazida à tona na oralidade: ela não é mais simplesmente recalcada ou ignorada; é exposta, elaborada e ordenada para um melhor domínio e exploração da sua força, num planejamento o mais definível possível do seu curso pela sociedade.

Com a opção por vocábulos comprometidos de maneira radical com ambos os campos (religioso e sexual), além da paródia de expressões e orações consideradas sagradas, o narrador cria um jogo em que se ligam as duas pontas de uma via discursiva que, para alguns, jamais deveriam se tocar, por representar heresia.

Entretanto, o que o conto descortina é antes de tudo a mistura, a raiz híbrida dos vocábulos, a sua contaminação no nascedouro, o que expõe, por extensão, o entrela frasal, intercalada no relato confessional, aparece inclusive uma paródia de parte da oração de São Francisco: "consolei mais do que fui consolado" (p. 19) ${ }^{137}$, em

137 Merece destaque aqui ao menos uma parte da bela oração atribuída a Francisco de Assis: "Ó mestre, fazei que eu procure mais consolar que ser consolado, compreender que ser compreendido, amar que ser amado... Onde houver ódio que eu leve o amor, onde houver discórdia, que eu leve a união, onde houver dúvidas, que eu leve a fé... Pois é dando que se recebe, é perdoando que se é perdoado...". Num outro conto de Cantos profanos, intitulado "Demo", o narrador, contra tudo, decreta: "Onde houver felicidade, que Eu leve a angústia. Onde houver harmonia, que Eu leve a discórdia. Onde houver tranquilidade, que Eu leve o desassossego. Onde houver esperança, que Eu leve o desespero..." (p. 64). Enquanto a oração são-franciscana faz a exaltação do dom, o "Demo" (anagrama imperfeito de dom) nega, abala e rasura. Porém, é curioso notar que, por vezes, interpreta-se a assertiva "é dando que se recebe" como uma proposta mesquinha de troca de favores. Os versos da oração, contudo, vão além, ao declarar o ato de receber no próprio ato de dar. Não se trata de dar para ganhar 
que, ao verbo consolar, adere-se um segundo sentido, buscado na acepção sexual do substantivo "consolo", significando dildo, substituto artificial do pênis.

o que poderia ser uma simples reversão sem mais consequências entre dois elementos expõe antes a lógica paradoxal em que, de fato, só o pecado redime. Afinal, que necessidade haveria do perdão, se não existisse o pecado? O divino ato de perdoar se liga ao ato humano de pecar e como que dele depende, amarrando-se um ao outro de forma inarredável.

Descendo, portanto, simultaneamente pelas raízes dos dois campos semânticos, sagrado e profano, o texto finda com o termo "Padre", numa coda que, por sua vez, recupera a ambivalência entre a ideia de santo ou representante de Deus (sagrado, puro, divino, assexuado) e aquele outro homem, o qual, por meio do sexo, engendra (profano, impuro, humano, sexuado): o pai.

A imbricação etimológica de padre e pai revela mais que uma simples correlação linguística; ela clareia radicalmente o nascedouro comum de ambos os territórios, relação em geral escondida pelo princípio de naturalização, que cega à medida que aproxima os elementos dos olhos: "no inferno não creio, nos céus, sim, pra sempre bendito, fé no Eterno, louvado seja, não é, Padre?” (p. 19).

em troca; antes, no ato desprendido mesmo de dar é que está o recebimento (é dando que se recebe). Formulando melhor: o que o dom afirma é a própria possibilidade de dar. 0 dom é justo aquilo cujo recebimento só se pode afirmar se ele é posto em prática. Mais uma vez, é ao dar que se recebe, de uma maneira aparentemente paradoxal e por vezes ininteligível ao senso comum, que tudo valora e capitaliza. Comparece aí a paródia do "Demo", que inverte necessariamente a lógica cristalizada em torno tanto da oração quanto da figura do santo/homem Francisco de Assis: desde que toda fé, paz e harmonia desejadas na tão famigerada oração não foram suficientes, enquanto propostas, a virada desconstrutora da paródia desestabiliza, revolucionando o modo de pensar sobre a oferta, o presente do dom, mostrando outra faceta, que se faz necessária justo lá onde a paz e o amor se engessaram em vocábulos e propostas enfraquecidos: "onde houver harmonia, que eu leve a discórdia". Se a harmonia é sinal de morbidez, a discórdia surge como nova proposta. Quando a paz é sinônimo de indiferença ou de medo, justo aí é preciso, ainda uma vez, impor-lhe um abalo. 
Como acontece com os demais vocábulos ambivalentes acima arrolados, por todo o texto se nota o comprometimento da "pureza", a impossibilidade de separação das áreas.

A profanação, que se vinha mantendo longe e mesmo oposta à sacralidade, de repente é reconhecida na sua relação com o campo do sexual. Assim, a ordem desses saberes (e poderes) tremula à vista do leitor, sofrendo um forte abalo sísmico (ou orgástico) em mais esse canto profano. 


\section{REFERÊNCIAS}

AGÊNCIA PATRÍCIA GALVÃO. Disponível em: <http://agenciapatriciagalvao. org.br>. Acesso em: 20 ago. 2017.

CARTA CAPITAL. No Brasil, um estupro a cada 11 minutos. Disponível em: https://www.cartacapital.com.br/sociedade/no-brasil-um-estuproa-cada-11-minutos. Acesso em: 17 ago. 2017.

DERRIDA, Jacques. Mal de arquivo: uma impressão freudiana. Tradução Cláudia de Moraes Rego. Rio de Janeiro: Relume Dumará, 2001.

DERRIDA, Jacques. Papel-máquina. Tradução de Evando Nascimento. São Paulo: Estação Liberdade, 2004.

FERREIRA, Aurélio Buarque de Holanda. Novo Dicionário Aurélio de Língua Portuguesa. Rio de Janeiro: Nova Fronteira, 1994.

FOUCAULT, Michel. História da sexualidade. Tradução Maria Thereza da Costa Albuquerque. Rio de Janeiro: Graal, 1980. v. I.

MATOS, Gregório de. Obra poética. 2. ed. Rio de Janeiro: Record, 1990.

NASCIMENTO, Evando. Cantos profanos. São Paulo: Biblioteca azul, 2014.

RABELO, Manuel Pereira. Vida e morte do excelente poeta lírico, o doutor Gregório de Matos e Guerra - Crônica do viver baiano seiscentista. Salvador: Janaína, 1969.

RICOEUR, Paul. A memória, a história, o esquecimento. Tradução de Alain François et alii. Campinas: Unicamp, 2007. 


\title{
A CONDIÇÃO HUMANA EM “TERRA À VISTA”
}

Em seu livro A condição humana, Hannah Arendt analisa as transformações ocorridas ao longo da história nas capacidades laborais do homem, tanto quanto estabelece a crítica de diversos pensadores modernos acerca das distinções, por exemplo, entre trabalho e obra. Em dada altura de suas reflexões, a pensadora afirma:

\begin{abstract}
A mudança mais radical da condição humana que podemos imaginar seria uma emigração dos homens da Terra para algum outro planeta. Tal evento, já não inteiramente impossível, implicaria em que o homem teria de viver sob condições, feitas por ele mesmo, inteiramente diferentes daquelas que a Terra lhe oferece. o labor, o trabalho, a ação e, na verdade, até mesmo o pensamento como o conhecemos deixariam de ter sentido em tal eventualidade. Não obstante, até mesmo esses hipotéticos viajores terrenos ainda seriam humanos; mas a única afirmativa que poderíamos fazer quanto à sua 'natureza' é que são ainda seres condicionados, embora sua condição seja agora, em grande parte, produzida por eles mesmos (ARENDT, p. 18).
\end{abstract}

Algumas das hipóteses então lançadas nessa parte do livro se confirmam com o passar do tempo, especialmente com a corrida espacial, desenvolvida mais freneticamente a partir do ano de lançamento do livro de Arendt, as quais os diversos eventos que envolvem a exploração do espaço a partir da década de 1960, com a chegada do homem à Lua, vão solidificar. 
Atualmente, uma empresa holandesa lançou o projeto denominado Mars One. Desde 2013, cidadãos de todo o globo já se inscrevem nesse que se anuncia ao mesmo tempo como programa de tevê e programa espacial, com o intuito de colonizar o planeta Marte a partir de 2025. O projeto, que não conta com verbas governamentais, traz no nome a promessa de ser o primeiro de uma série, e oferece viagem só de ida em direção aos módulos de vivência que, promete, serão implantados em solo marciano pouco antes da ida dos primeiros colonos.

Embora o idealizador do programa não veja com bons olhos a comparação com qualquer outro reality show, consta do contrato a ser firmado entre as partes que a atuação dos futuros migrantes seja filmada durantetodo otempo. Entre abril eagosto de 2013, duzentas mil pessoas em todo o mundo se inscreveram para participar do Mars one.

Desse modo, enquanto traçamos novos planos de colonização, desta vez do espaço, o problema da distribuição de terras segue irresoluto aqui na Terra. Dos paradoxos com que convivemos hoje, no conjunto das sociedades que habitam a superfície do planeta, este é apenas um singelo exemplo. Por entre guerras, ascensão de ondas neofascistas e enormes fossos de desigualdade, jamais nos impusemos como necessário que primeiro resolvêssemos a questão da mera subsistência, ligada à distribuição de terra, água e alimento, a fim de somente depois podermos partir para tentar habitar outras paragens.

No Brasil, o direito a terra é previsto na constituição, mas nenhum governo foi capaz de resolver o problema das concentrações de enormes extensões, em grande parte improdutivas, nas mãos de algumas poucas famílias proprietárias. Povos indígenas, quilombolas e comunidades inteiras de trabalhadores rurais sem terra seguem na luta por um lugar onde plantar e colher. Em meados de 2017 já se registra um número recorde de assassinatos em conflitos por terra, com 37 mortes entre janeiro e maio, segundo a Comissão Pastoral da Terra ${ }^{138}$.

138 Fonte: COMISSÃO PASTORAL DA TERRA. CPT Amazonas lançará relatório Conflitos no Campo Brasil 2016. Disponível em: https://www.cptnacional.org.br/publicacoes/noticias/cpt/ 3820-cpt-amazonas-lancara-relatorio-conflitos-no-campo-brasil-2016. Acesso em: 17 jul. 2017. 
Olhando-se por esse ângulo, programas como o Mars one, diferentemente do que pode parecer, não são um passo natural e consequente no caminho do desenvolvimento científico e tecnológico, apesar de anunciarem que já é possível inclusive estender o raio de vida do humano para além do nosso planeta.

Pelo contrário, até: observando as atuais relações geopolíticas, com um máximo de cinismo poder-se-ia argumentar, pela ótica do capital, que é mesmo necessário que haja Áfricas (empobrecidas), para que possa haver os EUA (cada vez mais ricos). De igual modo e pela mesma lógica perversa, é preciso que se esgotem os recursos necessários à vida aqui, a fim de que se justifique o envio de um pequeno número de pessoas a outras partes do universo, ainda que sem qualquer certeza de sobrevivência e de uma ulterior proliferação da espécie.

Radicalizando-se enfim a lógica que rege os dois polos desse paradoxo, constituído por uma vasta base de miséria que gera um pico de opulência, podemos afirmar que, mesmo tendo desenvolvido tecnologias avançadas ao ponto de podermos habitar um outro planeta, a mentalidade segue presa ao paradigma da exploração.

A intenção que move os vultosos investimentos feitos no desenvolvimento das tecnologias voltadas para essa nova colonização parece ser antes provar que se pode sobreviver por mais um tempo, conseguindo, a qualquer custo, o acréscimo de um pequeno respiro. Em diferentes áreas do pensamento, foram séculos de produção e reprodução de discursos que propalavam um avanço para além da mera sobrevivência da espécie, para ao final se reduzirem, contraditoriamente, a um apoio prático à premência mínima da garantia de sobrevida para um pequeno grupo de privilegiados do capital, contra uma maioria muda e esmagadora de deserdados da sorte.

Trata-se de uma postura que anula, de uma só vez, tanto a noção de humanidade como conjunto de diferentes povos que têm o direito de ser preservados (embora vivamos num contexto em que falar em direitos soe quase cândido), quanto a concepção de vida como bem 
supremo a ser protegido. De qualquer ponto de vista que se tome uma proposição como essa, de degradação do planeta e povoação sem futuro certo de uma outra estância, ela nos parece mais que perigosa: obtusa, antiética e mesmo psicopata.

Caminhando portanto a passos rápidos contra o sentido ainda vigente, embora aparentemente moribundo, de humanidade, em sua relação com a ideia de felicidade coletiva, o que se mostra é antes um novo, mesquinho e redutor empreendimento explorador, muito ao modo das antigas colonizações de descoberta do Novo Mundo, ou seja, feitas para poucos, que usarão, eliminarão ou abandonarão a todos os demais, só que agora no nível espacial.

Pode-se afirmar que, fora do ponto de vista da predação e do lucro, centrais para o capital, não há qualquer fundamento de maior escopo humanitário regendo aqui. Olhando desse ângulo, resistir durante tanto tempo tem sido mesmo um lance de sorte!

São reflexões provocadas pelo conto "Terra à vista", 139 do livro Cantos profanos, de Evando Nascimento, texto declaradamente inspirado no projeto holandês de colonização de Marte, tanto quanto no filme Gravidade140, de 2013, dirigido por Alfonso Cuarón ${ }^{141}$.

139 No título "Terra à vista", a expressão "à vista" insinua a atuação, no enredo, do poder do capital, afinal maior responsável pela destruição das condições de vida no planeta Terra. Para além de designar simplesmente a terra firme avistada ao longe, augúrio dos navegadores marítimos, a expressão se refere agora à Terra (com maiúscula) abatida, explorada e liquidada "à vista", como no comércio. O nome do conto revela ainda, de modo sutil, uma relação entre a colonização antiga e a futura e, ao mesmo tempo, a diferença entre elas, como se verá adiante.

140 o tom discretamente cômico da narrativa de Nascimento se origina, em parte, do absurdo da situação a que realmente chegamos; em outra, do aspecto paródico quanto à "ficção científica", gênero ao qual se filia o filme Gravidade, cujo título, aliás, aponta para uma curiosa ambivalência, indicando tanto a força que nos prende à Terra, quanto a gravidade da situação em que nos encontramos hoje.

1410 conto "Terra à vista" pode ser comparado ao que tradicionalmente se chamava ficção científica; com a diferença importante, porém, de que é muito menor, aqui, a preocupação com a verossimilhança, geralmente presente no detalhamento técnico dos objetos e eventos, na ficção científica. Além disso, a ficção científica tradicional projetava eventos que viriam a ser realizados num futuro distante, enquanto que a ficção de Nascimento se constrói dentro de um tempo que devorou já essas distâncias temporais: ali o passado é anulado e o futuro parece mais próximo do que se imaginava. "Terra à vista" provoca assim uma 
O conto de Nascimento é autodeclarado relatório, "o relatório mais isento possível”, escrito às vésperas do ano 2150 pelo provável último representante da espécie humana na órbita de Marte:

Sou o derradeiro sobrevivente deste módulo enviado para cá em 2080 e pertenço à segunda geração de filhos de migrantes. Formávamos até recentemente a mais importante das quinze colônias implantadas em solo marciano, numa colaboração internacional. 'Internacional' é modo ultrapassado de dizer, vício de linguagem que herdei dos bisavós, como consignado nos livros de História. Segundo consta nos atuais informes, não há mais nações, apenas conglomerados que tentam administrar os recursos finais do planeta. Escrevo essas coisas para o fato de, eventualmente, um navegante intergalático um dia se deparar com as ruínas do que fomos. Perdemos toda a identidade restante, o canibalismo grassa faz décadas entre os descendentes, numa guerra sem fim. (NASCIMENTO, p. 51-52) ${ }^{142}$.

Com base nos relatos do narrador, sabemos que, após diversas tentativas bem sucedidas de recriar artificialmente, em laboratório, a vida botânica e animal na Terra, uma bactéria teria destruído todos os resultados dessas experiências, e, junto, teria dizimado também dois décimos da humanidade, o que foi considerado uma vantagem, dadas as novas dificuldades de nutrição da população restante. Teria sido aí, ainda segundo as suas informações, que alguns blocos geopolíticos resolveram desenterrar os projetos de colonização do planeta vermelho.

A narrativa se passa após uma Terceira Guerra Mundial, que teria varrido do mapa o Oriente Médio, por meio de bombardeios nucleares, e "apaziguado" enfim as Coreias. O gelo dos polos já teria derretido, passando eles a serem "considerados zonas francas, dominadas pela máfia global, por assim dizer terra de ninguém” (p. 53).

\footnotetext{
rasura na significação do adjetivo "científica", até há pouco simplesmente recuperável, no contexto mais geral, e em especial quando se seguia ao termo ficção. Questiona, portanto, certas facetas da ciência e, junto com elas, o conceito de ficção científica.

142 A partir desta, todas as citações sem identificação de obra devem ser entendidas como retiradas de: NASCIMENTO, Evando. Cantos profanos. São Paulo: Biblioteca azul, 2014.
} 
Por entre reflexões curiosamente pouco nostálgicas para os parâmetros atuais, sobre aspectos da História, sobre Deus, a finitude e a infinitude, esse remanescente, denominado apenas "Eu", tem acesso a informações vindas da Terra, como o desencadeamento de uma

Quarta Guerra, em razão da escassez de recursos e da fome generalizada. Os governos dos agrupamentos geopolíticos (...) denominados de UNOs, perderam o controle para movimentos anárquicos, que se apossaram das novíssimas máquinas de guerra. Como sempre, o mais potente triunfará, malgrado todos os outros povos (p. 55).

Numa boa mostra do que seria um desenrolar do modo como já agimos hoje, esse "Eu", ainda que ciente da existência de todo um conhecimento acumulado, reconhece, referindo-se à Terra: "Temos acesso a todos os saberes provenientes de lá, apesar de utilizarmos muito pouco. Nunca nos deram o direito a pesquisa própria, somos antes cobaias em situações extremas" (p. 55). A situação é limítrofe e, tudo indica, sem saída. Não há contato com outro representante da espécie: afora "o invisível rival" que o "Eu" criou "para não endoidecer de vez" (p. 55).

Isolado, imóvel e sem poder tocar a terra ou um outro corpo, ele afirma: "Os familiares me visitam com frequência, dão conselhos e se esfumam no ar" (p. 55). Mesmo assim, em meio à "sólida solidão" em que se encontra, o último homem conta com a "sorte" de haver ao menos um outro humano "no módulo dez": "O painel só registra dois sinais residuais de vida, o meu é um deles." (p. 55)

Resume por fim:

Esse é o drama, das quinze colônias marcianas, apenas duas resistem, numa me encontro sozinho, o derradeiro companheiro sucumbiu há duas semanas, prefiro não informar como. Sei que há baterias e víveres escondidos em algum túnel entre o segundo e o terceiro módulo, mas ainda não encontrei o roteiro. Pode ser que meu único adversário, o do décimo módulo, lá chegue antes de mim, preciso continuar, não posso continuar - farei tudo para conquistar as reservas, onde quer que estejam, tenho um corpo de vantagem (p. 56). 
O corpo, nosso tão amado e idolatrado corpo, cintila então como um mero sinal residual, quiçá o último vestígio do que denominamos hoje a "condição humana". Ele perde também o seu atributo primeiro de sentir, desejar tocar e ser tocado. De depositário vivo de sentidos, afetos e sensibilidade, tudo isso que a ele se aderiu ao longo da história, o corpo se reduz a uma "vantagem". O ensejo ao embate, presente tanto na criação de um inimigo imaginário quanto na ideia de vencê-lo na luta pela sobrevivência, avulta como traço último, definitivo e marcante do humano. Não importa onde esteja - se em condições ditas normais, aqui na Terra, ou extremas, na órbita de um outro planeta -, assim que vislumbra a existência de um outro vivente, o primeiro pensamento do "Eu" é derrotá-lo, contando para isso com "um corpo de vantagem". Em tal condição, o corpo não é mais a âncora de um complexo de sentimentos humanos que foi um dia; é antes o instrumento que resta para marcar um território. Ainda que isso venha a significar uma solidão ainda maior, o "Eu" lutará contra o outro pelas reservas de víveres, não pensando, por exemplo, em dividi-las com ele. A luta pelo domínio sobre o outro replica, em nível individual e no solo de Marte, o que ocorre, coletivamente, aqui na Terra, condenando-nos, ainda uma vez, ao niilismo.

o homem, que no antigo postulado de Protágoras era "a medida de todas as coisas", não aparece mais na condição de modelo para tudo o que possa criar a partir e em prol do humano. Ao contrário, a essa altura todas as "coisas" já foram inventadas, usadas e descartadas. O último homem, solitário, migra agora para uma vida sem quaisquer dos "entraves" que o ligavam à Terra.

Em nome do domínio sobre o outro, a humanidade abdica, conscientemente ou não, a tudo o que auxiliava no construto da sua condição, e que passa, logicamente, pela alteridade. O corpo como local dos sentidos é neutralizado em nome da luta renhida que, ao final, significará a própria eliminação da espécie. Aliás, que seria um humano sozinho, isolado, livre da alteridade? Em condições como essa que o conto apresenta, seria ele ainda um humano? 
Numa análise comparativa entre os movimentos de colonização de fins da Idade Média e os atuais, o professor Guillermo Giucci afirma que por um lado é possível estabelecer a comparação, embora por outro se trate de eventos totalmente diferentes:

O submetimento da alteridade pelas armas e pelo verbo divino, (...) as figuras do cativo indígena, do náufrago abandonado e do índio intérprete, nada disso existe na conquista moderna, a do sistema solar. (...) Mas hoje nos remetemos a uma forma de subjugação que se distancia progressivamente do marco de referência humano, pois persegue a eliminação do corpo e do som. É a conquista clean, informatizada, robotizada"(GIUCCI, p. 7). "Por trás da agonia dos antigos valores, (...) perfila-se - de forma cada vez mais perturbadora - a gênese de uma transformação profunda e difícil de captar: o cancelamento da intimidade do ser humano com o ambiente natural ou artificial que o cerca. (...) o projeto solar se abre para o infinito (...) no interior de um vazio onde as noções de fronteira e de corporalidade parecem diluir-se e carecem de substância."(GIUCCI, p. 9). "A etapa que se inicia para a humanidade - a etapa interplanetária -, que o viajante norte-americano do espaço Armstrong confunde com o progresso da ciência e da tecnologia, pode não ser agradável nem justa, mas irrompe no cenário da história sem se preocupar com os matizes e possuída de uma vontade férrea de exterminar, não só Deus e o passado, como o próprio planeta Terra (GIUCCI, p. 14).

Assim como nos livros de ficção anteriores, também em Cantos profanos a escrita de Evando Nascimento encena questões que interessam a quem pensa sobre, por exemplo: por que é que buscamos saber o que viemos fazer na Terra? Qual a razão de conservamos ainda hoje a ideia utópica da existência de Deus? Haverá um próximo estágio para a condição humana, dentro ou fora do planeta? Num futuro não muito distante, será possível ao homem adiar infinitamente a morte? Qual é o peso de cada afeto? o que seria hoje o que se chama a humanidade? 


\section{REFERÊNCIAS}

ARENDT, Hannah. A condição humana. Tradução Roberto Raposo. 5 ed. Rio de Janeiro: Forense Universitária, 1991.

COMISSÃO PASTORAL DA TERRA. CPT Amazonas lançarárelatório Conflitos no Campo Brasil 2016. Disponível em: <https://www.cptnacional.org. br/publicacoes/noticias/cpt/3820-cpt-amazonas-lancara-relatorioconflitos-no-campo-brasil-2016>. Acesso em: 17 jul. 2017.

FOUCAULT, Michel. Microfísica do poder. Tradução Roberto Machado. Rio de Janeiro: Graal, 1982.

GIUCCI, Guillermo. Velhos e novos mundos: da conquista da América ao domínio do espaço cósmico. Tradução Gloria Rodríguez. Revista Estudos Históricos. Rio de Janeiro, vol. 4, n. 7, 1991, p. 3-18.

NASCIMENTO, Evando. Cantos profanos. São Paulo: Biblioteca azul, 2014. 